\title{
Auto-DR and Pre-cooling of Buildings at Tri-City Corporate Center
}

\author{
Rongxin Yin, Peng Xu, Sila Kiliccote \\ Lawrence Berkeley National Laboratory
}

November 2008 


\section{Acknowledgements}

Lawrence Berkeley National Laboratory is responsible for this project. It was developed as part of Southern California Edison's (SCE's) Emerging Markets \& Technology program under internal project number DR 08-02 and by the U.S. Department of Energy under Contract No. DE-AC02-05CH11231. Project manager Angelo Rivera conducted this technology evaluation with overall guidance and management from Carlos Haiad of SCE's Design \& Engineering Services For more information on this project, contact angelo.rivera@sce.com. The authors would like to thank the California Energy Commission's PIER Program for their on-going support of the LBNL Demand Response Research Center pre-cooling research.

\section{Disclaimer}

This document was prepared as an account of work sponsored by the United States Government. While this document is believed to contain correct information, neither the United States Government nor any agency thereof, nor The Regents of the University of California, nor any of their employees, makes any warranty, express or implied, or assumes any legal responsibility for the accuracy, completeness, or usefulness of any information, apparatus, product, or process disclosed, or represents that its use would not infringe privately owned rights. Reference herein to any specific commercial product, process, or service by its trade name, trademark, manufacturer, or otherwise, does not necessarily constitute or imply its endorsement, recommendation, or favoring by the United States Government or any agency thereof, or The Regents of the University of California. The views and opinions of authors expressed herein do not necessarily state or reflect those of the United States Government or any agency thereof or The Regents of the University of California. 


\section{CONIENTS}

ABSTRACT 1

EXECUIIVE SUMMARY __ 2

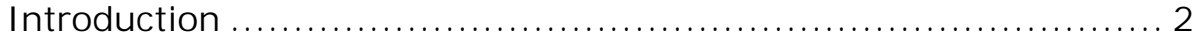

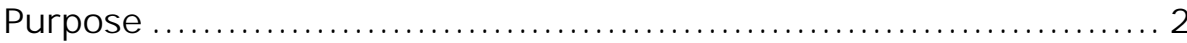

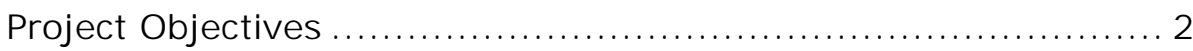

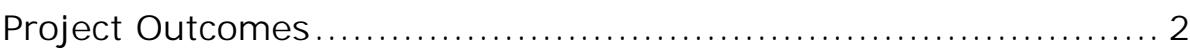

INTRODUCTION

Background and Overview ...................................... 1

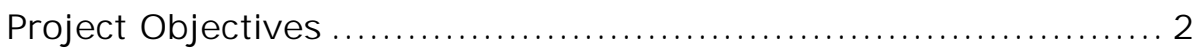

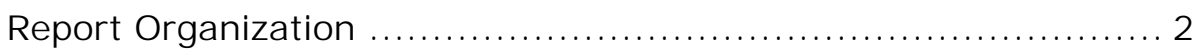

Developmentof Optimal Pre-cooung Strategies

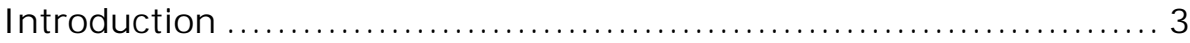

Data Collection of Tri-City Corporate Center....................... 3

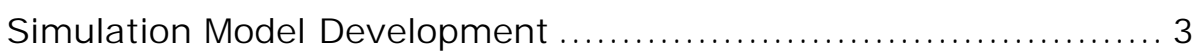

Inputs for the Initial Simulation Model......................... 3

Building Description ........................................ 3

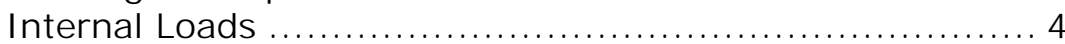

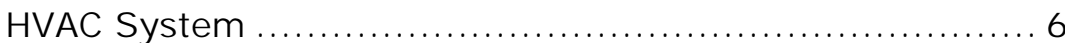

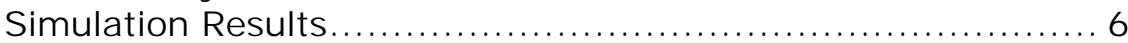

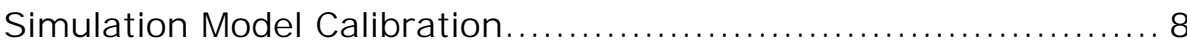

Simulation Model Calibration Criteria........................... 8

Real Weather Data ........................................... 9

Internal Loads adjustments .................................. 9

Calibrated I nitial Simulation Models ........................... 12

Comparison of Monthly Measured Data..................... 12

Comparison of Daily Measured Data....................... 13

Comparison of Hourly Measured Data....................... 14

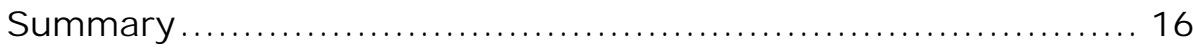

Optimization Of Pre-cooung Strategies 17

Optimal Pre-cooling Strategies ............................... 17

When to Pre-cool: CPP Versus Non-CPP? .................. 17

Pre-cooling Strategies.......................................... 19

Simulation Results of Pre-cooling Strategies.................... 20

Optimal Pre-cooling Strategies ............................ 20

Summary of Simulation Results............................. 21 
Pre-cooling and DR Event Field Test Results..................... 23

Pre-cooling Strategy Field Test............................ 23

DR Event Field Test ....................................... 23

Confirmation of the simulation model .................... 23

Lbnl baseline model....................................... 25

DR Event Field Test Results .............................. 26

Comparison of actual data and simulation prediction ............ 28

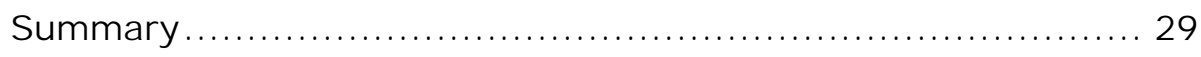

\section{COMPARISON OF DRQATMTH EQUESTAND BEST ___ 30}

Introduction to Energy Simulation Tools ....................... 30

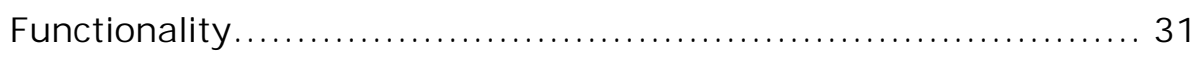

General Features............................................. 31

Difference in Building Dynamics Prediction.................... 32

Comparison of simulations with real building data............... 33

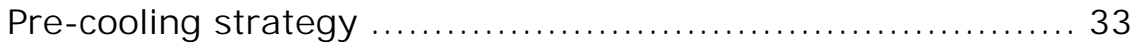

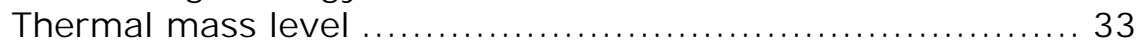

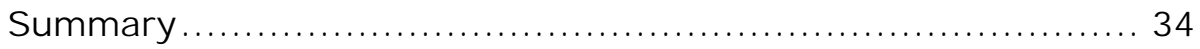

CONCLUSIONSAND RECOMMENDATIONS

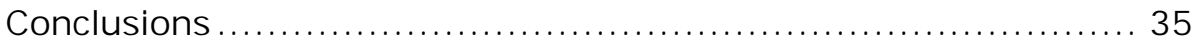

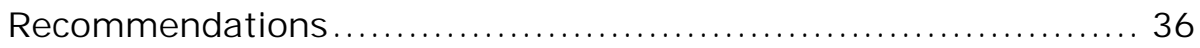

Retrences _ 37

APPENDIX A - BUILING AUDITS___ 38

Two Carnegie Plaza ......................................... 38

One Carnegie Plaza ......................................... 39

One Carnegie Plaza (smaller building) ......................... 40

One Vanderbilt.................................................. 41

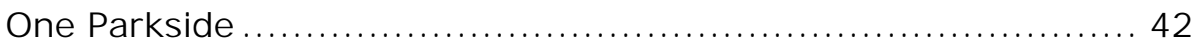

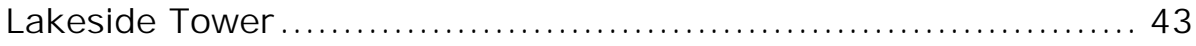

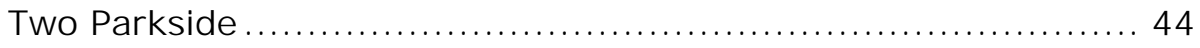

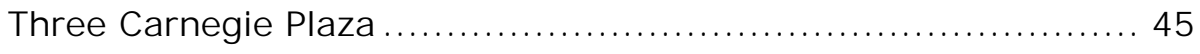

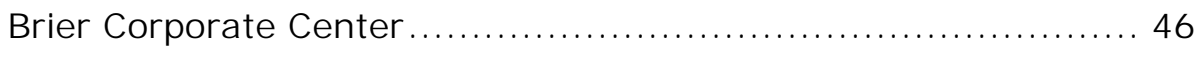

Vanderbilt Plaza ............................................. 47

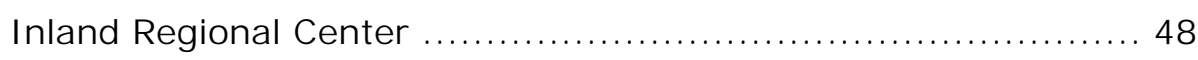

APPENDIX B- BUIDING INTERNAL LOADS AND SCHEDULES__ 49

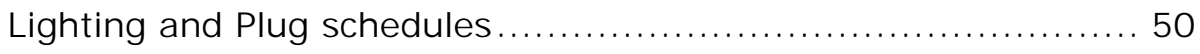




\section{ApPendix C - CaLbration Results}

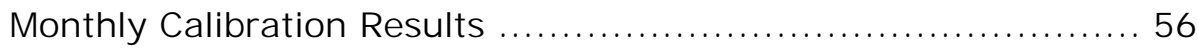

Weekly and Daily Calibration Results .......................... 58

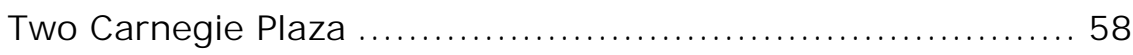

One Carnegie Plaza ............................................ 60

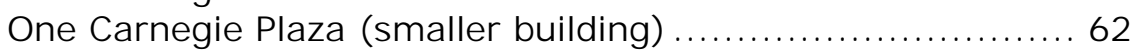

One Vanderbilt.................................................. 64

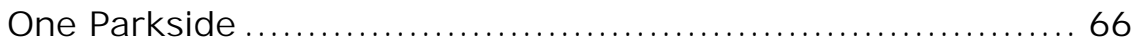

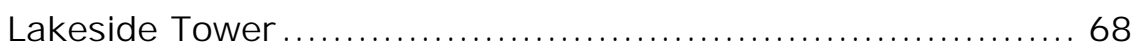

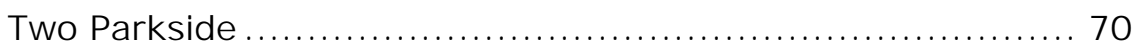

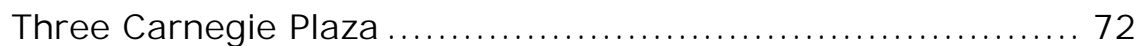

Brier Corporate Center ...................................... 74

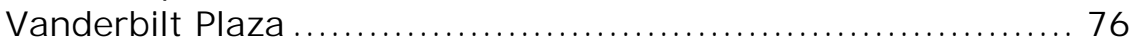

Inland Regional Center........................................ 78

ApPendix D- Fed RESUlts _ $\mathbf{8 0}$

Energy Analysis on Auto-DR Event Days........................ 80

Demand Plot on Auto-DR Events Days ......................... 91

Economic Analysis on Auto-DR Events Days..................... 97

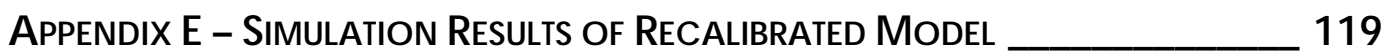




\section{FigURES}

Figure 1: Schedule of Occupancy on Weekdays ...................... 5

Figure 2: Schedules of Lighting and Plug Power Densities on

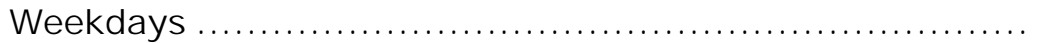

Figure 3: Calibrated Schedules of Lighting and Plug Power

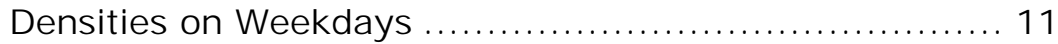

Figure 4: Calibrated Schedules of Lighting and Plug Power Densities on Weekend and Holidays ....................... 12

Figure 5: Daily Electrical Consumption of Simulation Model vs. Actual Electrical Consumption in July................... 14

Figure 6: Daily Electrical Consumption of Simulation Model vs. Actual Electrical Consumption in August .................. 14

Figure 7: Hourly Electrical Consumption of Simulation Model vs. Actual Electrical Consumption One day in August.......... 15

Figure 8: Hourly Electrical Consumption of Simulation Model vs. Actual Electrical Consumption One day in August.......... 15

Figure 9: Distribution of Daily Max Demand throughout Summer Period-Three Carnegie Plaza ............................... 18

Figure 10: Distribution of daily max demand throughout summer period-One Vanderbilt................................... 19

Figure 13: Simulation Results of Optimal Pre-cooling Strategies ..... 21

Figure 14: Pre-cooling Strategies - Auto-DR $\ldots \ldots \ldots \ldots \ldots \ldots \ldots \ldots \ldots \ldots \ldots \ldots \ldots \ldots \ldots$

Figure 15: Outside Air Temperature Comparison Between Baseline Day and Auto-DR Day ................................... 24

Figure 16: Field Test Results of Pre-cooling Strategies on Auto-DR Day ........................................................ 27

Figure 17: DOE-2 Loads Calculation Procedure $\ldots \ldots \ldots \ldots \ldots \ldots \ldots \ldots \ldots \ldots \ldots \ldots \ldots$

Figure 18: EnergyPlus Loads Calculation Procedure $\ldots \ldots \ldots \ldots \ldots \ldots . \ldots 32$

Figure 19: Simulation Results of Different Thermal Mass Level for eQUEST and DRQAT .................................... 34 


\section{TABIES}

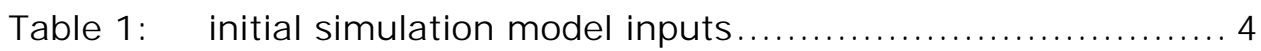

Table 2: $\quad$ Building Internal Loads For I nitial Simulation Models ....... 5

Table 3: $\quad$ Building Internal Loads for I nitial Simulation Model ........ 7

Table 4: Comparison between Simulation Results and Actual

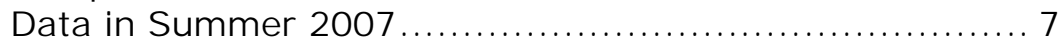

Table 5: Acceptable tolerance for Monthly, Daily and Hourly

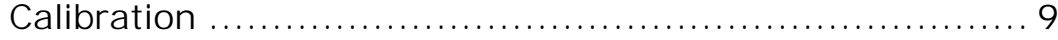

Table 6: Building Internal Loads for Calibrated Simulation Model.. 11

Table 7: Comparison between Calibrated Simulation Results and

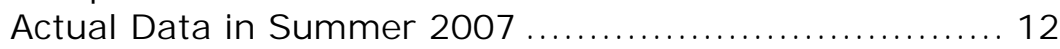

Table 8: $\quad$ Simulation Results of Different Pre-cooling Strategies.... 21

Table 9: $\quad$ Simulation Results of Optimal "Step Temperature Set Up" Pre-cooling Strategy (Three Carnegie Plaza) ......... 22

Table 10: Temperature Comparison between Baseline Days and

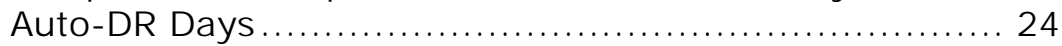

Table 11: Summary of Auto-DR days and Corresponding Baseline

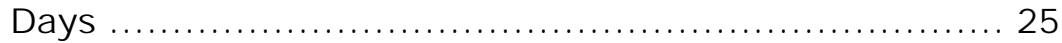

Table 12: Summary of Auto-DR Field Test Results - Three Carnegie Plaza ............................................. 27

Table 13: Summary of Optimal Pre-cooling Strategy Recalibrated Model ..................................... 28

Table 14: General Features of Building Energy Simulation Tool.... 31

Table 15: Simulation Results of Demand Shed for DR Strategy

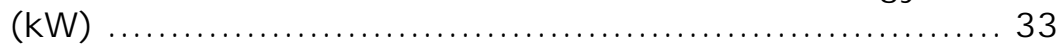

\section{EQUATIONS}

Equation 1: Criteria for Assessing the Difference between Simulation Model and Measured Data..................... 9

Equation 2: Average Variance of Hourly Outside Air Temperature.... 24

Equation 3: Computed Baseline Model $\ldots \ldots \ldots \ldots \ldots \ldots \ldots \ldots \ldots \ldots \ldots \ldots \ldots \ldots \ldots \ldots \ldots \ldots \ldots \ldots$

Equation 4: Regression Model With Morning Load Adjustment ........ 26 


\section{ABSTRACT}

Over the several past years, Lawrence Berkeley National Laboratory (LBNL) has conducted field tests for different pre-cooling strategies in different commercial buildings within California. The test results indicated that pre-cooling strategies were effective in reducing electric demand in these buildings during peak periods. This project studied how to optimize pre-cooling strategies for eleven buildings in the Tri-City Corporate Center, San Bernardino, California with the assistance of a building energy simulation tool - the Demand Response Quick Assessment Tool (DRQAT) developed by LBNL's Demand Response Research Center funded by the California Energy Commission's Public Interest Energy Research (PIER) Program. From the simulation results of these eleven buildings, optimal pre-cooling and temperature reset strategies were developed. The study shows that after refining and calibrating initial models with measured data, the accuracy of the models can be greatly improved and the models can be used to predict load reductions for automated demand response (Auto-DR) events. This study summarizes the optimization experience of the procedure to develop and calibrate building models in DRQAT. In order to confirm the actual effect of demand response strategies, the simulation results were compared to the field test data. The results indicated that the optimal demand response strategies worked well for all buildings in the Tri-City Corporate Center.

This study also compares DRQAT with other building energy simulation tools (eQUEST and BEST). The comparison indicate that eQUEST and BEST underestimate the actual demand shed of the pre-cooling strategies due to a flaw in DOE2's simulation engine for treating wall thermal mass. DRQAT is a more accurate tool in predicting thermal mass effects of DR events.

Key words: Pre-cooling, Demand response, Thermal mass, Auto-DR, Building energy simulation tool. 


\section{EXECUTIVE SUMMARY}

\section{INTRODUCTION}

The potential for utilizing building thermal mass for load shifting and peak demand reduction has been demonstrated by LBNL by many field experiments. Through the California Energy Commission's PIER-funded Demand Response Research Center, a building energy simulation tool, Demand Response Quick Assessment Tool (DRQAT), was developed to estimate the DR potential and optimize DR strategies in buildings. As part of a pilot project to demonstrate the usefulness of DRQAT, the tool was used to optimize the temperature control strategies in eleven buildings at the Tri-City Corporate Center, San Bernardino, California in 2008. By comparing the pre-cooling strategies' simulation results with measured field data, optimal demand response strategies are proposed to maximize demand response savings for these buildings.

The research team based their work on SCE's Auto-DR program activities managed by Global Energy Partners (GEP). GEP conducted the building audits and worked with local contractors to automate the participation of the buildings in SCE's DR programs.

\section{PURPOSE}

The purpose of this research project was to demonstrate how to use the Demand Response Quick Assessment Tool (DRQAT) to predict the effects of various precooling strategies for buildings. Field tests were conducted in eleven buildings at the Tri-City Corporate Center. The measured data from these Auto-DR events were compared to the simulation results. The product of this research study was to develop a general procedure to estimate potential peak demand reductions of various DR strategies.

\section{ProjectObj eCtives}

The primary objective of this research was to develop pre-cooling and temperature reset strategies that are most effective for the eleven buildings and to support the long term strategic goal of evaluation and deployment of control strategies to reduce peak demand in California. The demand response strategies used in this study can be programmed into the control systems of these buildings and be used in future DR events.

\section{PROJ ECTOUTCOMES}

Optimal pre-cooling and temperature reset strategies were developed based on the simulation results of these eleven buildings. Both "pre-cooling with exponential temp set up" and "pre-cooling with step temp set up" were determined to be optimal control strategies to achieve maximum demand savings. Of these two strategies, "pre-cooling with step temp set up" was implemented during the field tests. The study showed that after refining and calibrating the initial models with measured 
data, the accuracy of the models could be greatly improved and the models could be used to predict load reductions in these buildings on Auto-DR event days within $\pm 5 \%$ of accuracy. This report summarizes the optimization experience and the procedure to develop and calibrate building models in DRQAT. 


\section{INTRODUCTION}

\section{BACKG ROUND AND OVERVIEW}

The potential for utilizing building thermal mass for load shifting and peak demand reduction has been demonstrated by LBNL in many field experiments (Xu et al. 2005, Xu and Yin 2006, Xu and Zagreus 2007). Over the past five years, a series of research studies have been conducted to investigate strategies for using building thermal mass to shift building cooling load in cooperation with three utilities in California (PG\&E, SCE and SMUD). In these studies and tests, significant demand reduction in large commercial buildings has been demonstrated with relatively small impacts on occupant comfort.

The California Energy Commission's Public Interest Energy Research (PIER) PRogram has funded LBNL's Demand Response Research Center's (DRRC) studies regarding how to use pre-cooling strategies to reduce building peak electricity demand. As part of this CEC-funded research, LBNL tested the pre-cooling strategy in one office building at the Tri-City Corporate Center in San Bernardino, Southern California. The strategy involved maintaining zone temperatures at the lower end of the comfort range $\left(72^{\circ} \mathrm{F}\right)$ during the occupied hours before the peak period and floating the zone temperatures up to the high end of the comfort range $\left(78^{\circ} \mathrm{F}\right)$ during the peak period. With this strategy, the cooling plant-related electricity demand was reduced by 30 to $50 \%$ during peak hours from $12 \mathrm{pm}$ to $5 \mathrm{pm}$ without any thermal comfort complaints submitted to the operations staff.

The DR and pre-cooling strategies worked well on test days with peak outside air temperatures as high as $110^{\circ} \mathrm{F}$. The load sheds in hot climates were more predictable and stable than for load sheds in cooler climates, primarily because electricity used for cooling on hot days tend to be a larger portion of the whole building electricity load than that for cooler days.

In 2006, with support from the California Energy Commission's PIER Demand Response Research Center, a quick assessment simulation tool was developed that could be used to predict demand reduction, operating cost savings, and occupant thermal comfort impacts associated with using building thermal mass control. The tool is the Demand Response Quick Assessment Tool (DRQAT). The tool incorporates prototypical buildings and equipment and allows the user to specify a relatively small number of important parameters in order to determine a quick assessment for building thermal mass strategies. The tool compares peak power demand, operating costs, and comfort between conventional and building thermal mass control strategies. The input parameters of the tool include building type, floor area, location, occupancy schedule, utility rates, and few other variables that change the demand-limiting strategy. These parameters are believed to have the greatest influence on demand reduction and cost savings. Since the release of the beta version of the tool, more than 100 users from all over the world have requested copies of the tool and have used it.

With the help of the simulation tool and the previous field test experience, the precooling tests were expanded to all eleven buildings in the Tri-City Corporate Center in 2008. All of these buildings participated in SCE's automated DR (Auto-DR) programs. In 2008, the buildings participated in the Critical Peak Pricing (CPP) 
Program manually and continued to enable automation of DR in their facilities. AutoDR is a DR signaling infrastructure that delivers DR event related information to the customers' energy management and controls systems (EMCS). The technology platform has been developed by the California Energy Commission's PIER Demand Response Research Center and it is currently being considered to be an open, interoperable standard to deliver DR signals to end uses. The eleven buildings in this study are the first buildings in SCE's service territory that will be automated through an embedded software client within their EMCS. The embedded software client "listens" to the DR event information being published by the DR automation server (DRAS) and calls for pre-programmed strategies when the DR event is called. All the other participants are using a device that is external to their system that listens to the DR event related information and converts these to relay closures to indicate price information (Piette et al. 2008). Regardless of which client is being used, the customers have the flexibility to opt-out at anytime before or during the event.

Field tests and simulation analyses were conducted for all eleven buildings. The simulation activity involved developing calibrated DRQAT models for each building. Using the calibrated models, the demand response strategies were optimized to maximize the corresponding demand response savings.

\section{ProjectOBj ECTIVES}

The primary objective of this research is to develop pre-cooling and temperature reset strategies that are most effective for the eleven Tri-City Corporate Center buildings and to support the long term strategic goal of evaluation and deployment of control strategies to reduce peak demand in California. The demand response strategy determined to be most effective in this study will be programmed into the control systems of these buildings so the building owner can utilize them in future DR events.

\section{REPORTORGANIZATION}

Chapter 1, Development of Optimal Pre-Cooling Strategies, provides an introduction with descriptions of previous studies, the theory and the objectives of this research. Chapter 2, Optimization of Pre-Cooling Strategies, covers the use of DRQAT to develop optimal pre-cooling strategies. Chapter 3, Pre-Cooling Field Test Analysis, provides field test results and procedures that were followed to refine the DRQAT models with the test data of the eleven office buildings. Chapter 4, Comparison of DRQAT with EQUEST and BEST, compares DRQAT with two building energy simulation tools. Chapter 5, Conclusions and Recommendations, completes the report and discusses future work. The Appendices include building descriptions, calibration results and field results. 


\section{Developmentof Optimal Pre-COOUng STRATEGIES}

\section{INTRODUCTION}

This section describes data collection, initial DRQAT model development, and model calibration of eleven buildings. Based on the calibrated simulation models, simulation analyses were conducted to determine how to discharge thermal mass efficiently and smoothly with no rebound.

\section{DATA COUECTION OF TRI-CITY CORPORATE CENTER}

Data collection for simulation of the buildings was coordinated with Global Energy Partners' (GEP) technical audit process. The technical person visiting the site was provided with a site survey that was used to collect data from facilities and was then used for the simulations. Due to lack of time, forms were not completed. The feedback suggested that most of the information related to schedules and demand intensities was not available for these facilities anyway. The approach was then modified to use default values because the buildings were "typical" office buildings. Additional information on the DR strategies was collected by LBNL through a half hour interview with the facility engineer.

\section{SIMULATION MODEL DeVElOPMENT}

The simulation models were developed after available building information was collected. The sufficiency and precision of the collected data, such as building envelope, building load data, HVAC system characteristics, building operation had direct impact on the accuracy of the simulation results. The more sufficient and precise the collected data, the more accurate the models' predictions.

\section{INPUIS FOR THE INITIALSIMULATION MODEL}

\section{BUILDING DESCRIPTION}

Table 1 presents a summary of the building description and the internal loads of eleven Tri-City Corporate Center buildings. The building audits provided general building information, such as number of stories, gross area, and other relevant information. The axis, length and width of each building were measured by using Google Earth, which provides maps and satellite images of the buildings. 
TABLE 1: INITIAL SIMULATION MODEL INPUTS

BUI LDI NG BASI C I NPUT - I NITI AL VALUES

\begin{tabular}{|c|c|c|c|c|c|c|c|}
\hline Site Name & $\begin{array}{c}\text { GROSS } \\
\text { AREA } \\
\text { (SQ FT) }\end{array}$ & $\begin{array}{l}\text { LENGT } \\
\text { H (FT) }\end{array}$ & $\begin{array}{l}\text { WIDTH } \\
\text { (FT) }\end{array}$ & $\begin{array}{l}\text { FLOOR } \\
\text { HEIGHT } \\
\text { ( FT) }\end{array}$ & $\begin{array}{l}\text { WWR_- } \\
\text { SN }\end{array}$ & $\begin{array}{l}\text { WWR } \\
\text { EW }\end{array}$ & $\begin{array}{c}\text { BUI LDI NG } \\
\text { ORI ENTATI ON }\end{array}$ \\
\hline $\begin{array}{l}\text { Two Carnegie } \\
\text { Plaza }\end{array}$ & 68,955 & 300 & 115 & 12 & 0.50 & 0.50 & 45 \\
\hline $\begin{array}{l}\text { One Carnegie } \\
\text { Plaza }\end{array}$ & 62,800 & 300 & 105 & 12 & 0.50 & 0.50 & 315 \\
\hline $\begin{array}{l}\text { One Carnegie } \\
\text { Plaza (smaller } \\
\text { building) }\end{array}$ & 38,808 & 270 & 70 & 12 & 0.50 & 0.50 & 45 \\
\hline One Vanderbilt & 73,730 & 205 & 90 & 12 & 0.25 & 0.25 & 315 \\
\hline One Parkside & 70,069 & 175 & 100 & 12 & 0.60 & 0.60 & 0 \\
\hline Lakeside Tower & 112,717 & 210 & 90 & 12 & 0.60 & 0.60 & 0 \\
\hline Two Parkside & 80,750 & 250 & 110 & 12 & 0.40 & 0.40 & 0 \\
\hline $\begin{array}{l}\text { Three Carnegie } \\
\text { Plaza }\end{array}$ & 83,698 & 420 & 100 & 12 & 0.40 & 0.40 & 45 \\
\hline $\begin{array}{l}\text { Brier Corporate } \\
\text { Center }\end{array}$ & 104,501 & 350 & 100 & 12 & 0.40 & 0.40 & 45 \\
\hline Vanderbilt Plaza & 119,035 & 200 & 150 & 12 & 0.40 & 0.40 & 0 \\
\hline $\begin{array}{l}\text { Inland Regional } \\
\text { Center }\end{array}$ & 81,079 & 350 & 115 & 12 & 0.30 & 0.30 & 45 \\
\hline
\end{tabular}

Notes:

WWR_SN: window to wall ratio for south and north sides of the building;

WWR_EW: window to wall ratio for east and west sides of the building;

Floor Height: height of a single floor;

Building Orientation: building north axis is specified relative to true north and the value is specified in degrees from "true north" (clockwise is positive).

\section{INTERNAL LOADS}

Internal loads such as occupants, lighting, and plug load constitute the majority of cooling loads in office buildings. Table 2 presents the building internal load inputs for the initial simulation models. Based on building type and year of built, lighting power intensities were estimated using the corresponding vintage of California's Energy Efficiency Standards for Residential and Non Residential Buildings (Title 24, CEC 1987-2005). The plug intensity was estimated to be $0.75 \mathrm{~W} / \mathrm{ft}^{2}$, and occupancy intensity was estimated to be $390 \mathrm{ft}^{2}$ per person. The lighting, equipment and occupancy schedules (Figures 1 ad 2 ) were the same as specified in the typical operation of commercial buildings benchmark models developed by DOE's Commercial Building Team, (Torcellini, Deru et al2008). 


\section{Table 2: Building Internal Loads For Initial Simulation Models}

\begin{tabular}{|c|c|c|c|c|}
\hline \multicolumn{5}{|c|}{ BUI LDI NG I NTERNAL LOAD } \\
\hline Site Name & $\begin{array}{r}\text { Year } \\
\text { Constructed }\end{array}$ & $\begin{array}{r}\text { LIGHTING } \\
\text { DENSITY } \\
\text { ( w/ SQ FT) }\end{array}$ & $\begin{array}{r}\text { Plug Density } \\
\text { ( W/ SQ FT) }\end{array}$ & $\begin{array}{c}\text { OCCUPANCY } \\
\text { (SQ FT/ PER } \\
\text { PERSON) }\end{array}$ \\
\hline Two Carnegie Plaza & 1990 & 1.60 & 0.75 & 390 \\
\hline One Carnegie Plaza & 1988 & 1.60 & 0.75 & 390 \\
\hline One Carnegie Plaza & 1988 & 1.60 & 0.75 & 390 \\
\hline One Vanderbilt & 1988 & 1.60 & 0.75 & 390 \\
\hline One Parkside & 1993 & 1.60 & 0.75 & 390 \\
\hline Lakeside Tower & 1990 & 1.60 & 0.75 & 390 \\
\hline Two Parkside & 2001 & 1.20 & 0.75 & 390 \\
\hline Three Carnegie Plaza & 2003 & 1.20 & 0.75 & 390 \\
\hline Brier Corporate Center & 2005 & 1.10 & 0.75 & 390 \\
\hline Vanderbilt Plaza & 2002 & 1.20 & 0.75 & 390 \\
\hline Inland Regional Center & 1994 & 1.60 & 0.75 & 390 \\
\hline
\end{tabular}

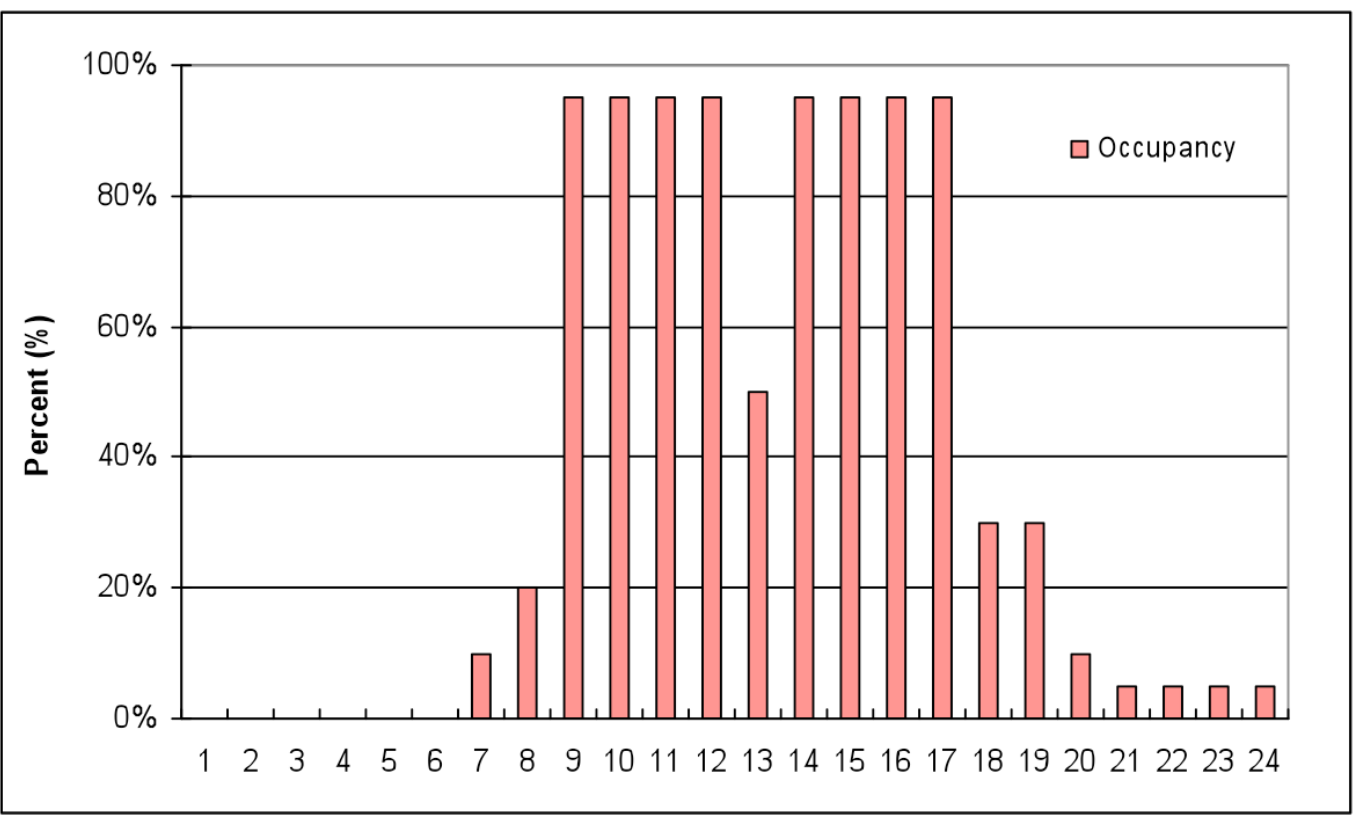

Figure 1: Schedule of Occupancy on Weekdays 


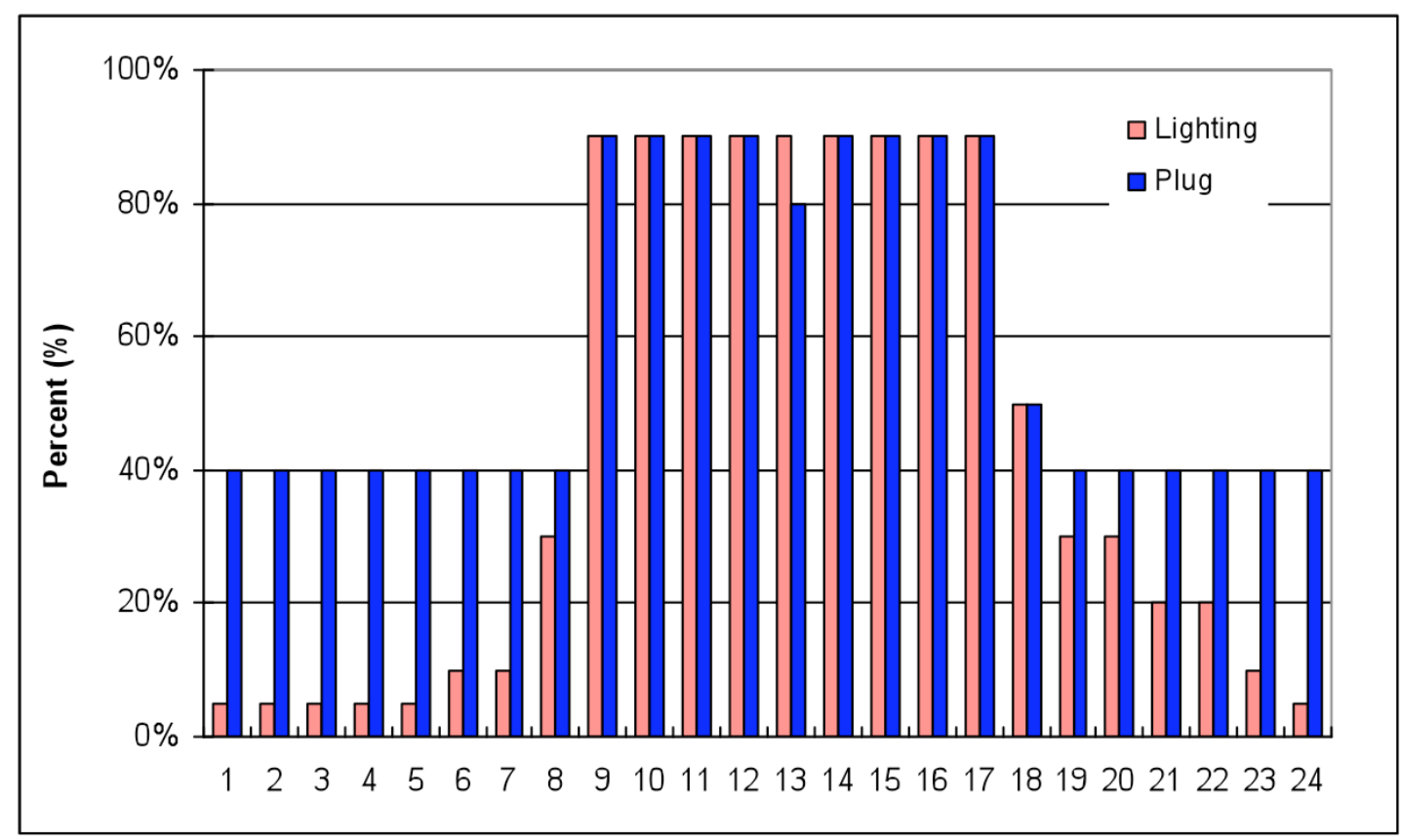

Figure 2: Schedules of Lighting and Plug Power Densities on Weekdays

\section{HVAC SYSTEM}

Table 3 summarizes each building's HVAC system type and capacity as well as zone temperature setpoints for each building. Most of the cooling systems are rooftop package DX units with VAV systems. The HVAC systems start between 6 am and 8 $\mathrm{am}$, and turn off around $6 \mathrm{pm}$ on weekdays. The zone temperature for each building is monitored and controlled by a fully equipped digital direct control (DDC) system which enable various global zone temperature reset strategies for demand response analysis. The normal zone temperature set points are about $77^{\circ} \mathrm{F}$ in the summer period.

\section{SIMULATION RESULTS}

Using all the information mentioned above, initial simulation models were developed for each building using DRQAT. Because of the many input assumptions made, the initial simulated models were then calibrated with measured data. For each initial simulation model, the absolute and the relative difference between the simulation results and the measured data were calculated. The electric consumption predicted by the simulation models were compared to the building's monthly utility bills and to some spot measurements. The simulation results and measured data from the summer of 2007 for each building were compared on a monthly and hourly basis.

As shown in Table 4, only two simulation models had results within $\pm 10 \%$ of the measured data. The simulated electricity consumption of the other nine buildings was much lower than the measured data and some monthly differences were larger than $20 \%$. 


\section{TABle 3: Building Internal Loads for Initial Simulation MOdel}

\begin{tabular}{|c|c|c|c|c|}
\hline \multirow{3}{*}{ Site Name } & \multirow{2}{*}{\multicolumn{2}{|c|}{ Cooling Plant }} & \multirow{3}{*}{$\begin{array}{c}\text { AIR } \\
\text { DISTRIBUTION } \\
\text { TYPE }\end{array}$} & \multirow{3}{*}{$\begin{array}{c}\text { ZONE TEMP } \\
\text { SET POI NTS } \\
\text { ( COOLI NG }{ }^{\circ} \text { F) }\end{array}$} \\
\hline & & & & \\
\hline & TYPE & CAPACITY & & \\
\hline Two Carnegie Plaza & Packaged DX Units & $\begin{array}{l}2 @ 55 \text { Ton } \\
2 @ 50 \text { Ton }\end{array}$ & VAV & 77 \\
\hline One Carnegie Plaza & Packaged DX Units & $\begin{array}{l}2 @ 55 \text { Ton } \\
2 @ 50 \text { Ton }\end{array}$ & VAV & 77 \\
\hline One Carnegie Plaza & Packaged DX Units & $\begin{array}{l}1 @ 50 \text { Ton } \\
1 @ 60 \text { Ton }\end{array}$ & VAV & 77 \\
\hline One Vanderbilt & Packaged DX Units & $\begin{array}{l}3 \text { @ } 55 \text { Ton } \\
1 @ 60 \text { Ton }\end{array}$ & VAV & 77 \\
\hline One Parkside & Packaged DX Units & $4 @ 55$ Ton & VAV & 77 \\
\hline Lakeside Tower & $\begin{array}{l}\text { Central Chiller } \\
\text { (reciprocating) }\end{array}$ & 2 @ 175 Ton & VAV & 77 \\
\hline Two Parkside & Packaged DX Units & 2 @ 90 Ton & VAV & 77 \\
\hline Three Carnegie Plaza & Packaged DX Units & $2 @ 50$ Ton & VAV & 77 \\
\hline Brier Corporate Center & Packaged DX Units & $\begin{array}{l}1 \text { @ } 80 \text { Ton } \\
2 \text { @ } 75 \text { Ton }\end{array}$ & VAV & 77 \\
\hline Vanderbilt Plaza & Packaged DX Units & $\begin{array}{l}2 @ 55 \text { Ton } \\
2 @ 50 \text { Ton }\end{array}$ & VAV & 77 \\
\hline Inland Regional Center & Packaged DX Units & $\begin{array}{l}2 @ 105 \text { Ton } \\
2 @ 90 \text { Ton }\end{array}$ & VAV & 77 \\
\hline
\end{tabular}

\section{Table 4: Comparison between Simulation Results and Actual Data in Summer 2007}

\begin{tabular}{|c|c|c|c|c|c|c|}
\hline \multirow{2}{*}{ Site NAME } & \multirow{2}{*}{ I NDEX } & \multicolumn{4}{|c|}{ MONTH (KWH) } & \multirow{2}{*}{$\begin{array}{r}\text { AVERAGE } \\
(\mathrm{KWH})\end{array}$} \\
\hline & & 6 & 7 & 8 & 9 & \\
\hline \multirow{4}{*}{$\begin{array}{l}\text { Two Carnegie } \\
\text { Plaza }\end{array}$} & Actual Data & 80,257 & 90,791 & 94,380 & 72,318 & 337,746 \\
\hline & Simulation & 62,173 & 72,467 & 73,364 & 63,207 & 271,212 \\
\hline & \multirow[t]{2}{*}{ Difference } & $-18,084$ & $-18,324$ & $-21,016$ & $-9,111$ & $-66,534$ \\
\hline & & $-23 \%$ & $-20 \%$ & $-22 \%$ & $-13 \%$ & $-20 \%$ \\
\hline \multirow{4}{*}{$\begin{array}{l}\text { One Carnegie } \\
\text { Plaza }\end{array}$} & Actual Data & 86,551 & 108,140 & 110,590 & 86,803 & 392,084 \\
\hline & Simulation & 57,388 & 67,155 & 67,973 & 58,429 & 250,944 \\
\hline & \multirow[t]{2}{*}{ Difference } & $-29,163$ & $-40,985$ & $-42,617$ & $-28,374$ & $-141,140$ \\
\hline & & $-34 \%$ & $-38 \%$ & $-39 \%$ & $-33 \%$ & $-36 \%$ \\
\hline \multirow{4}{*}{$\begin{array}{l}\text { One Carnegie } \\
\text { Plaza }\end{array}$} & Actual Data & 61,972 & 75,944 & 82,813 & 60,954 & 281,682 \\
\hline & Simulation & 34,743 & 41,128 & 41,530 & 35,408 & 152,808 \\
\hline & \multirow[t]{2}{*}{ Difference } & $-27,230$ & $-34,816$ & $-41,283$ & $-25,546$ & $-128,874$ \\
\hline & & $-44 \%$ & $-46 \%$ & $-50 \%$ & $-42 \%$ & $-46 \%$ \\
\hline \multirow[t]{4}{*}{ One Vanderbilt } & Actual Data & 146,649 & 165,824 & 178,890 & 140,342 & 631,705 \\
\hline & Simulation & 70,957 & 83,133 & 84,290 & 72,161 & 310,541 \\
\hline & \multirow[t]{2}{*}{ Difference } & $-75,692$ & $-82,691$ & $-94,601$ & $-68,180$ & $-321,165$ \\
\hline & & $-52 \%$ & $-50 \%$ & $-53 \%$ & $-49 \%$ & $-51 \%$ \\
\hline One Parkside & Actual Data & 100,114 & 115,745 & 121,942 & 94,950 & 432,751 \\
\hline
\end{tabular}




\begin{tabular}{|c|c|c|c|c|c|c|}
\hline & Simulation & 66,596 & 77,666 & 79,672 & 69,114 & 293,048 \\
\hline & \multirow[t]{2}{*}{ Difference } & $-33,518$ & $-38,079$ & $-42,270$ & $-25,836$ & $-139,703$ \\
\hline & & $-33 \%$ & $-33 \%$ & $-35 \%$ & $-27 \%$ & $-32 \%$ \\
\hline \multirow[t]{4}{*}{ Lakeside Tower } & Actual Data & 141,811 & 168,731 & 179,926 & 140,137 & 630,606 \\
\hline & Simulation & 136,240 & 156,353 & 160,384 & 139,776 & 592,754 \\
\hline & \multirow[t]{2}{*}{ Difference } & $-5,571$ & $-12,377$ & $-19,542$ & -361 & $-37,852$ \\
\hline & & $-4 \%$ & $-7 \%$ & $-11 \%$ & $0 \%$ & $-6 \%$ \\
\hline \multirow[t]{4}{*}{ Two Parkside } & Actual Data & 103,487 & 117,825 & 124,713 & 98,815 & 444,840 \\
\hline & Simulation & 63,266 & 72,744 & 74,712 & 65,006 & 275,728 \\
\hline & \multirow[t]{2}{*}{ Difference } & $-40,221$ & $-45,081$ & $-50,001$ & $-33,809$ & $-169,112$ \\
\hline & & $-39 \%$ & $-38 \%$ & $-40 \%$ & $-34 \%$ & $-38 \%$ \\
\hline \multirow{4}{*}{$\begin{array}{l}\text { Three Carnegie } \\
\text { Plaza }\end{array}$} & Actual Data & 67,019 & 80,051 & 86,552 & 67,728 & 301,350 \\
\hline & Simulation & 66,147 & 77,643 & 78,657 & 67,455 & 289,901 \\
\hline & \multirow[t]{2}{*}{ Difference } & -872 & $-2,408$ & $-7,895$ & -273 & $-11,449$ \\
\hline & & $-1 \%$ & $-3 \%$ & $-9 \%$ & $0 \%$ & $-4 \%$ \\
\hline \multirow{4}{*}{$\begin{array}{l}\text { Brier Corporate } \\
\text { Center }\end{array}$} & Actual Data & 159,325 & 178,754 & 187,255 & 164,857 & 690,191 \\
\hline & Simulation & 87,988 & 104,465 & 106,174 & 90,453 & 389,080 \\
\hline & \multirow[t]{2}{*}{ Difference } & $-71,337$ & $-74,289$ & $-81,081$ & $-74,404$ & $-301,111$ \\
\hline & & $-45 \%$ & $-42 \%$ & $-43 \%$ & $-45 \%$ & $-44 \%$ \\
\hline \multirow[t]{4}{*}{ Vanderbilt Plaza } & Actual Data & 127,048 & 152,719 & 165,028 & 125,764 & 570,559 \\
\hline & Simulation & 93,818 & 108,881 & 111,544 & 96,429 & 410,672 \\
\hline & \multirow[t]{2}{*}{ Difference } & $-33,230$ & $-43,838$ & $-53,484$ & $-29,335$ & $-159,887$ \\
\hline & & $-26 \%$ & $-29 \%$ & $-32 \%$ & $-23 \%$ & $-28 \%$ \\
\hline \multirow{4}{*}{$\begin{array}{l}\text { Inland Regional } \\
\text { Center }\end{array}$} & Actual Data & 95,139 & 109,179 & 115,479 & 89,562 & 409,359 \\
\hline & Simulation & 75,484 & 87,581 & 88,892 & 76,719 & 328,677 \\
\hline & \multirow[t]{2}{*}{ Difference } & $-19,655$ & $-21,598$ & $-26,587$ & $-12,843$ & $-80,682$ \\
\hline & & $-21 \%$ & $-20 \%$ & $-23 \%$ & $-14 \%$ & $-20 \%$ \\
\hline
\end{tabular}

\section{SimULATION MODEL CAUBRATION}

One office building "Three Carnegie Plaza" in Tri-City Corporate Center is used as the example to illustrate the initial simulation model calibration procedure. "Three Carnegie Plaza" is a typical office building: two stories with a large portion of the floor area covered with carpets. It has large single pane with low-e glazing areas on every sides of the building. The detailed building descriptions, inputs and simulation results are presented in the appendices of this report.

\section{Simulation Mode CaLbration CrTteria}

The calibration criteria used in this report is from the 2002 ASHRAE Guideline 14 Measurement of Energy and Demand Saving. The standard was developed for energy use and demand saving measurement and verification based on monthly, daily and hourly comparison. The more accurate the initial simulation models are, the more accurate DR sheds the models predict. 
The main focus of this study was to evaluate and verify the effect of pre-cooling strategies for decreasing electrical demand of the HVAC system during the peak period. The initial models were adjusted through a series of simulations until the monthly acceptable tolerances were achieved. The models were then calibrated to hourly data to achieve a higher level of accuracy. The following criteria (Equation 1) were used to assess the difference between the simulation results and measured data to determine whether the calibrated models sufficiently reflected the performance of the building: Mean Bias Error (MBE) (how well the energy consumption is predicted by the model as compared to the measured data) and $\mathrm{CV}$ (RSME) (how well a model matches the measured data due to the cancellation of errors). Table 5 includes the acceptable tolerance limits used in this analysis.

\section{Equation 1: Criteria for Assessing the Difference between Simulation Model and} Measured Data

$$
\begin{aligned}
& \mathrm{MBE}_{\text {month }}(\%)=\left[\frac{(\mathrm{M}-\mathrm{S})_{\text {month }}}{\mathrm{M}_{\text {month }}}\right] \times 100 \% \\
& \mathrm{CV}\left(\mathrm{RMSE}_{\text {month }}\right)(\%)=\left[\frac{\mathrm{RMSE}}{\overline{\mathrm{M}}_{\text {month }}}\right] \times 100 \% \\
& \mathrm{RMSE}_{\text {month }}=\left\{\frac{\left[\sum_{\text {month }}(\mathrm{M}-\mathrm{S})_{\text {month }}^{2}\right.}{\mathrm{N}_{\text {month }}}\right] \\
& \overline{\mathrm{M}}_{\text {month }}=\frac{\sum\left(\mathrm{M}_{\text {month }}\right)}{\mathrm{N}_{\text {month }}}
\end{aligned}
$$

Where $\mathrm{M}$ is the measured electric consumption ( $\mathrm{kWh}$ ) in one month, $\mathrm{S}$ is the

\begin{tabular}{|c|c|c|c|}
\hline I NDEX & MONTHLY & DAILY & HOURLY \\
\hline MBE & $\pm 5 \%$ & $\pm 10 \%$ & $\pm 20 \%$ \\
\hline CV(RMSE) & $\pm 15 \%$ & - & - \\
\hline
\end{tabular}
simulated electric consumption ( $\mathrm{kWh}$ ) during the same month, $\mathrm{N}$ is the number of months in the field test period.

\section{Table 5: Acceptable tolerance for Monthly, Daily and Hourly Calibration}

\section{REAL Weather DATA}

The initial models were run using TMY2 (Typical Meteorological Year) weather files available within DRQAT. For the calibration process, the measured weather data for 2007 and 2008 was downloaded from the EnergyPlus website according to the climate zone where these eleven buildings were located. Note that some modelers have reported using typical year weather data for model calibration before. This approach was not recommended since the utility data used for the comparison was incurred under actual weather conditions.

\section{INTERNAL LOADS ADJ USTIMENTS}

After comparing the initial simulation model results to the measured data, it appeared that the plug loads assumed for most of the buildings might be too low. The occupancy, lighting and plug schedules on different weekdays were assumed to be similar to each other throughout the year. To fine tune these schedules, the 
densities and schedules for lighting and plug loads were estimated based on the whole building electricity data for the heating period from November $1^{\text {st }}, 2007$ to February $28^{\text {th }}, 2008$. During this time period, the maximum outside temperature was $55^{\circ} \mathrm{F}$ or lower and the cooling plants were completed locked out. The whole building power during this period thus only included lighting, plug and fan power. The internal loads were separated out by analyzing the daily energy use of the buildings under extreme cold weather conditions. This method is applied to buildings where the heating sources are gas, steam, or hot water from other facilities.

Table 6 lists the inputs of the building internal loads for the calibrated simulation models. The lighting and occupancy schedules were similar to the initial simulation models, but the plug loads were increased.

Using "Three Carnegie Plaza" as an example, Figure 3 and Figure 4 show the lighting and plug load schedules on weekdays and weekend $\&$ holiday after the calibration. The electricity usage was constant during the unoccupied period. The occupancy schedule of the calibrated model was the same as that used for the initial simulation model. 


\section{Table 6: Building Internal Loads for Calibrated Simulation Model}

\begin{tabular}{|c|c|c|c|c|}
\hline \multicolumn{5}{|c|}{ BUI LDI NG I NTERNAL LOAD } \\
\hline Site Name & $\begin{array}{r}\text { Year } \\
\text { Constructed }\end{array}$ & $\begin{array}{r}\text { LIGHTING } \\
\text { DENSITY } \\
\text { ( W/ SQ FT) }\end{array}$ & $\begin{array}{r}\text { Plug Density } \\
\text { ( } w / \text { SQ FT })\end{array}$ & $\begin{array}{r}\text { OCCUPANCY } \\
\text { (SQ FT/ PER } \\
\text { PERSON) }\end{array}$ \\
\hline Two Carnegie Plaza & 1990 & 1.60 & 0.75 & 390 \\
\hline One Carnegie Plaza & 1988 & 1.60 & 1.50 & 390 \\
\hline One Carnegie Plaza & 1988 & 1.60 & 1.50 & 390 \\
\hline One Vanderbilt & 1988 & 1.60 & 1.80 & 390 \\
\hline One Parkside & 1993 & 1.60 & 1.40 & 390 \\
\hline Lakeside Tower & 1990 & 1.60 & 0.90 & 390 \\
\hline Two Parkside & 2001 & 1.20 & 1.50 & 390 \\
\hline Three Carnegie Plaza & 2003 & 1.20 & 0.60 & 390 \\
\hline Brier Corporate Center & 2005 & 1.10 & 1.40 & 390 \\
\hline Vanderbilt Plaza & 2002 & 1.20 & 1.00 & 390 \\
\hline Inland Regional Center & 1994 & 1.60 & 1.00 & 390 \\
\hline
\end{tabular}

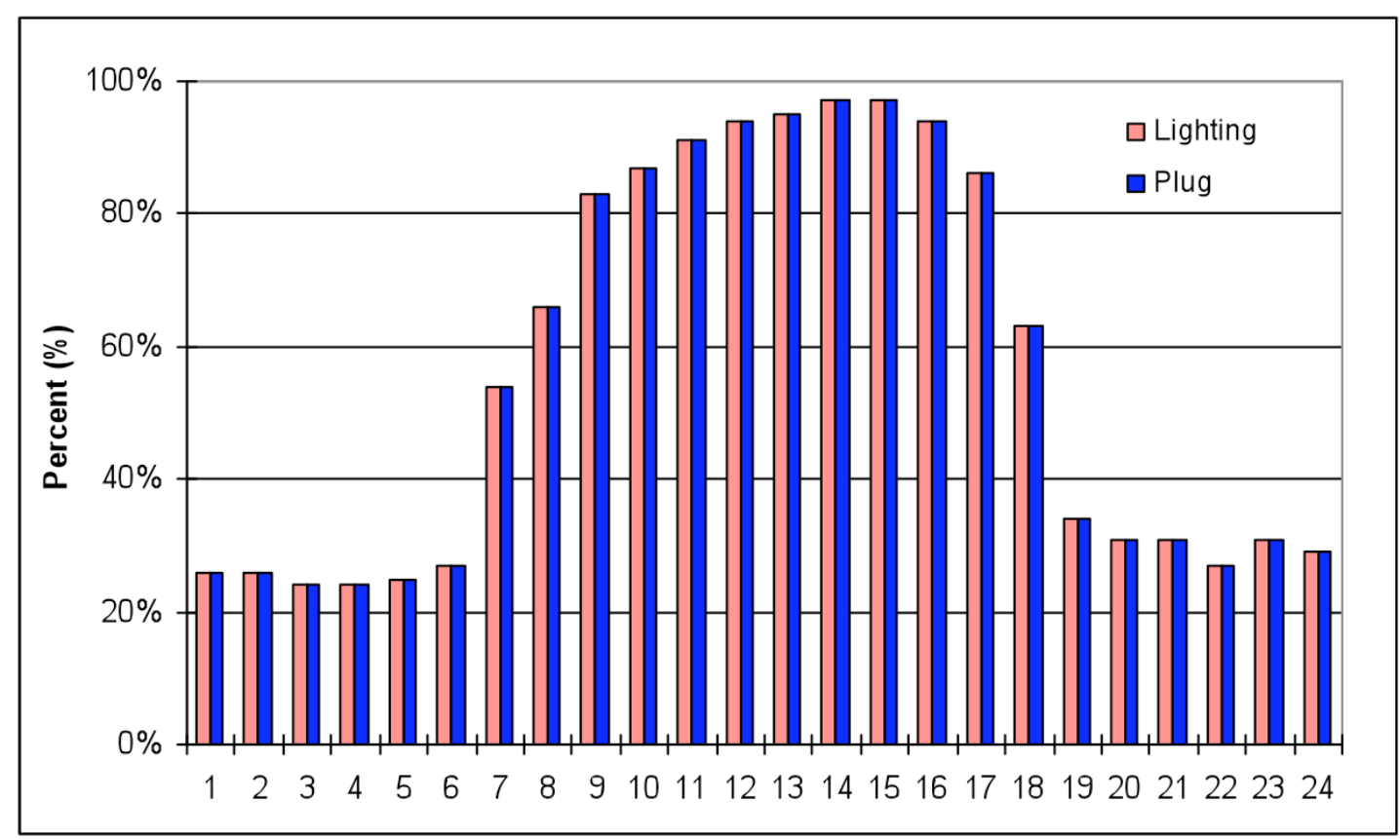

Figure 3: Calibrated Schedules of Lighting and Plug Power Densities on Weekdays 


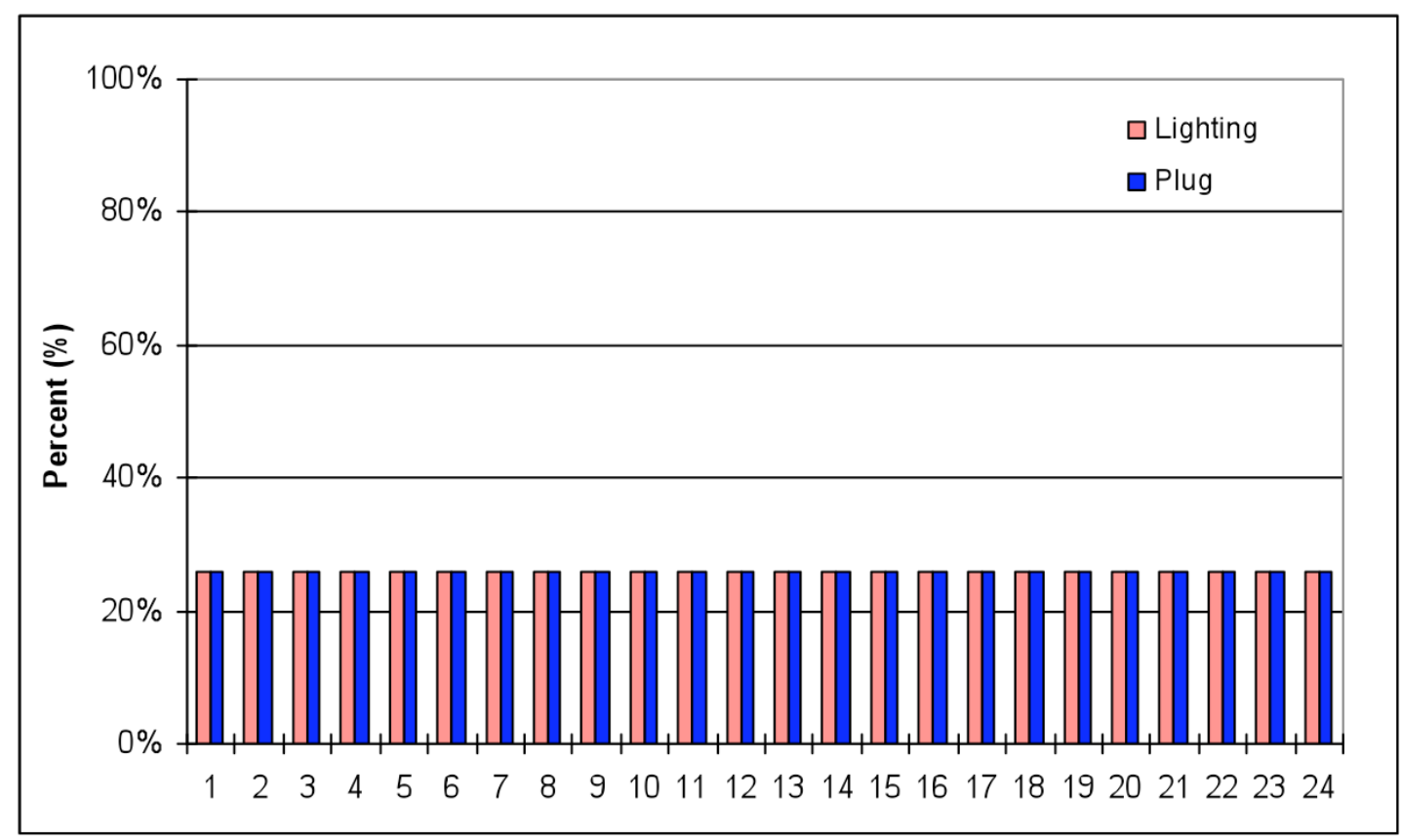

Figure 4: Calibrated Schedules of Lighting and Plug Power Densities on Weekend and HOLIDAYS

\section{CAUBRATED InITIALSIMULATION MOdELS}

\section{COMPARISON OF MONTHLY MEASURED DATA}

The simulation results of the calibrated models were compared with the measured monthly data. Table 7 indicates that the monthly simulation results were within $\pm 5 \%$ of the measured data. Some monthly percent errors were higher than the others, but still within $\pm 10 \%$. The densities and schedules for lighting and plug loads used in the models were constant throughout the year. In reality, they may vary slightly between individual days.

\section{Table 7: Comparison between Calibrated Simulation Results and Actual Data in} SUMMER 2007

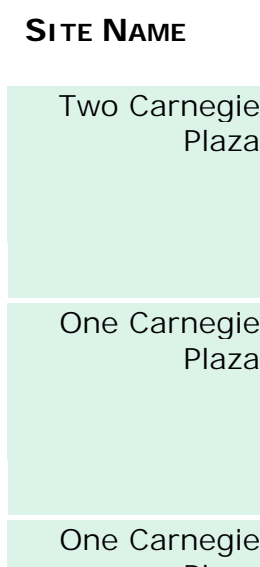

Plaza

\section{NDEX}

Measured

Simulation

Difference

Measured

Simulation

Difference

Measured

Simulation

\begin{tabular}{|r|r|}
\hline & \multicolumn{2}{|c|}{ MONT } \\
\hline $\mathbf{6}$ & $\mathbf{7}$ \\
\hline 80,257 & 90,791 \\
\hline 80,981 & 95,495 \\
\hline 724 & 4,704 \\
\hline $\mathbf{1 \%}$ & $\mathbf{5 \%}$ \\
\hline 86,551 & 108,140 \\
\hline 91,053 & 105,713 \\
\hline 4,502 & $-2,427$ \\
\hline $\mathbf{5 \%}$ & $-\mathbf{2} \%$ \\
\hline 61,972 & 75,944 \\
\hline 65,157 & 75,965 \\
\hline
\end{tabular}

8

94

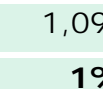

110,590

105, 737

$-4,853$

$-4 \%$

82,813

75,447
Average (KWH)

337,746

344,566

6,820

$2 \%$

392,084

384,753

$-7,331$

$-2 \%$

281,682

275,009 


\begin{tabular}{|c|c|c|c|c|c|c|}
\hline & \multirow[t]{2}{*}{ Difference } & 3,185 & 21 & $-7,366$ & $-2,514$ & $-6,674$ \\
\hline & & $5 \%$ & $0 \%$ & $-9 \%$ & $-4 \%$ & $-2 \%$ \\
\hline \multirow[t]{4}{*}{ One Vanderbilt } & Measured & 146,649 & 165,824 & 178,890 & 140,342 & 631,705 \\
\hline & Simulation & 148,845 & 169,345 & 168,898 & 135,664 & 622,752 \\
\hline & \multirow[t]{2}{*}{ Difference } & 2,196 & 3,520 & $-9,993$ & $-4,677$ & $-8,954$ \\
\hline & & $1 \%$ & $2 \%$ & $-6 \%$ & $-3 \%$ & $-1 \%$ \\
\hline \multirow[t]{4}{*}{ One Parkside } & Measured & 100,114 & 115,745 & 121,942 & 94,950 & 432,751 \\
\hline & Simulation & 104,489 & 122,594 & 123,318 & 96,093 & 446,493 \\
\hline & \multirow[t]{2}{*}{ Difference } & 4,375 & 6,849 & 1,376 & 1,143 & 13,742 \\
\hline & & $4 \%$ & $6 \%$ & $1 \%$ & $1 \%$ & $3 \%$ \\
\hline \multirow[t]{4}{*}{ Lakeside Tower } & Measured & 141,811 & 168,731 & 179,926 & 140,137 & 630,606 \\
\hline & Simulation & 149,166 & 170,884 & 174,826 & 141,030 & 635,906 \\
\hline & \multirow[t]{2}{*}{ Difference } & 7,354 & 2,153 & $-5,100$ & 893 & 5,301 \\
\hline & & $5 \%$ & $1 \%$ & $-3 \%$ & $1 \%$ & $1 \%$ \\
\hline \multirow[t]{4}{*}{ Two Parkside } & Measured & 103,487 & 117,825 & 124,713 & 98,815 & 444,840 \\
\hline & Simulation & 103,362 & 120,951 & 122,953 & 94,977 & 442,242 \\
\hline & \multirow[t]{2}{*}{ Difference } & -125 & 3,126 & $-1,760$ & $-3,838$ & $-2,598$ \\
\hline & & 0\% & $3 \%$ & $-1 \%$ & $-4 \%$ & $-1 \%$ \\
\hline \multirow{4}{*}{$\begin{array}{r}\text { Three Carnegie } \\
\text { Plaza }\end{array}$} & Measured & 67,019 & 80,051 & 86,552 & 67,728 & 301,350 \\
\hline & Simulation & 69,931 & 84,550 & 84,571 & 61,304 & 300,356 \\
\hline & \multirow[t]{2}{*}{ Difference } & 2,912 & 4,499 & $-1,981$ & $-6,424$ & -994 \\
\hline & & $4 \%$ & $6 \%$ & $-2 \%$ & $-9 \%$ & $0 \%$ \\
\hline \multirow{4}{*}{$\begin{array}{r}\text { Brier Corporate } \\
\text { Center }\end{array}$} & Measured & 159,325 & 178,754 & 187,255 & 164,857 & 690,191 \\
\hline & Simulation & 161,828 & 186,986 & 187,524 & 148,086 & 684,424 \\
\hline & \multirow[t]{2}{*}{ Difference } & 2,503 & 8,232 & 269 & $-16,771$ & $-5,767$ \\
\hline & & $2 \%$ & $5 \%$ & $0 \%$ & $-10 \%$ & $-1 \%$ \\
\hline \multirow{4}{*}{$\begin{array}{r}\text { Vanderbilt } \\
\text { Plaza }\end{array}$} & Measured & R127,048 & 152,719 & 165,028 & 125,764 & 570,559 \\
\hline & Simulation & 136,118 & 159,638 & 161,984 & 124,334 & 582,074 \\
\hline & \multirow[t]{2}{*}{ Difference } & 9,070 & 6,919 & $-3,044$ & $-1,430$ & 11,515 \\
\hline & & 7\% & $5 \%$ & $-2 \%$ & $-1 \%$ & $2 \%$ \\
\hline \multirow{4}{*}{$\begin{array}{r}\text { Inland Regional } \\
\text { Center }\end{array}$} & Measured & 95,139 & 109,179 & 115,479 & 89,562 & 409,359 \\
\hline & Simulation & 99,944 & 115,992 & 116,928 & 90,549 & 423,413 \\
\hline & \multirow[t]{2}{*}{ Difference } & 4,805 & 6,813 & 1,449 & 987 & 14,054 \\
\hline & & $5 \%$ & $6 \%$ & $1 \%$ & $1 \%$ & $3 \%$ \\
\hline
\end{tabular}

\section{COMPARISON OF DAILY MEASURED DATA}

The same building (Three Carnegie Plaza) was used to illustrate the results of the calibrated model. Figure 3 shows the standard lighting and plug load schedules for this building.

Figure 5 and Figure 6 show the comparison of the simulated and measured daily electrical usage for the whole building in July and August. The simulated electrical demand of the calibrated model was very close to the actual data. However, differences still existed in the electrical demand values on $7 / 16 / 2007$. Perhaps it was 
because of high internal loads in the building on that day, or the weather data provided by EnergyPlus did not match the actual local weather condition for that day. However, the calibrated simulation results still predicted the actual electric usage throughout the summer period very well.

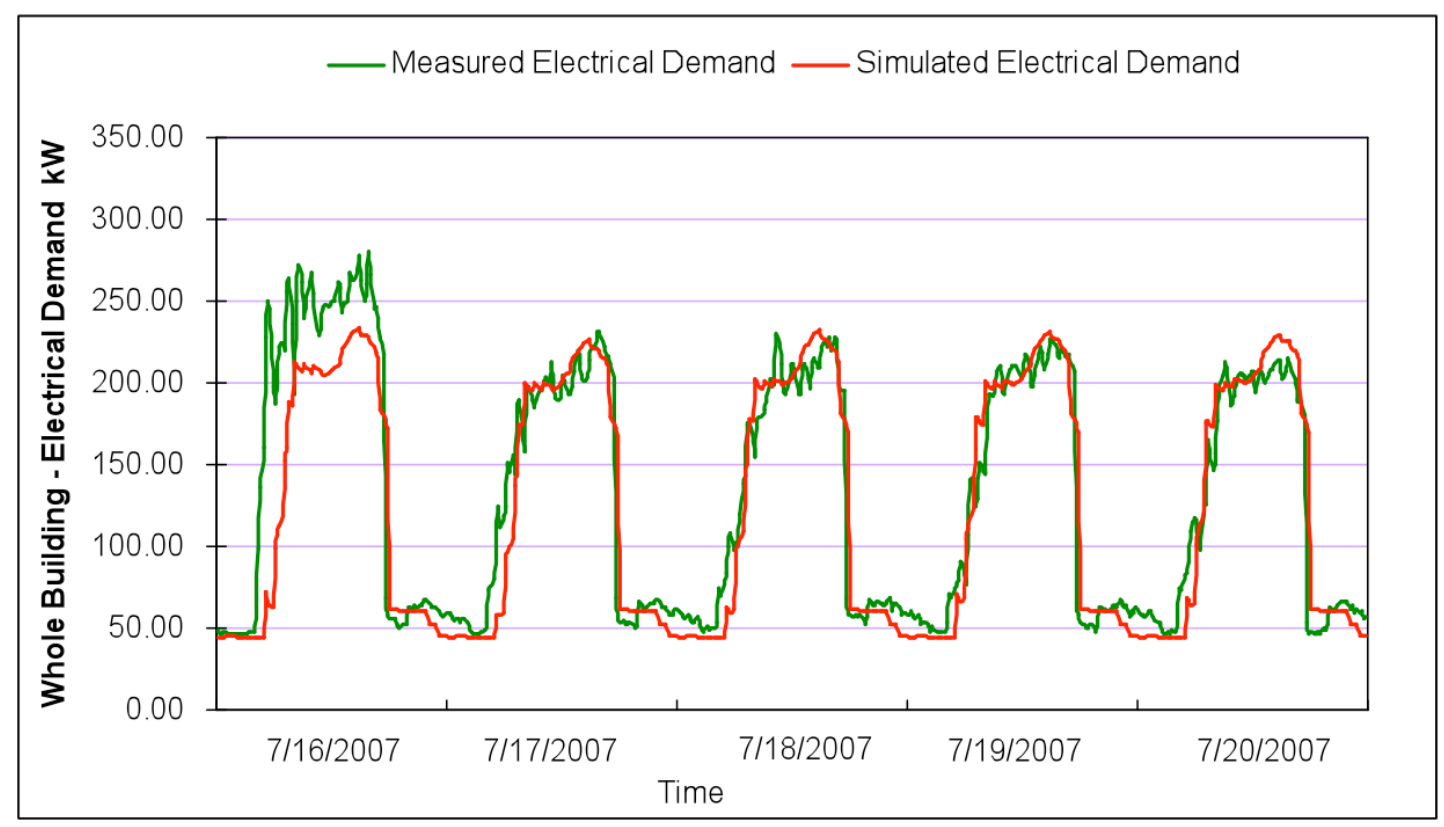

Figure 5: Daily Electrical Consumption of Simulation Model vs. Actual Electrical CONSUMPTION IN JULY

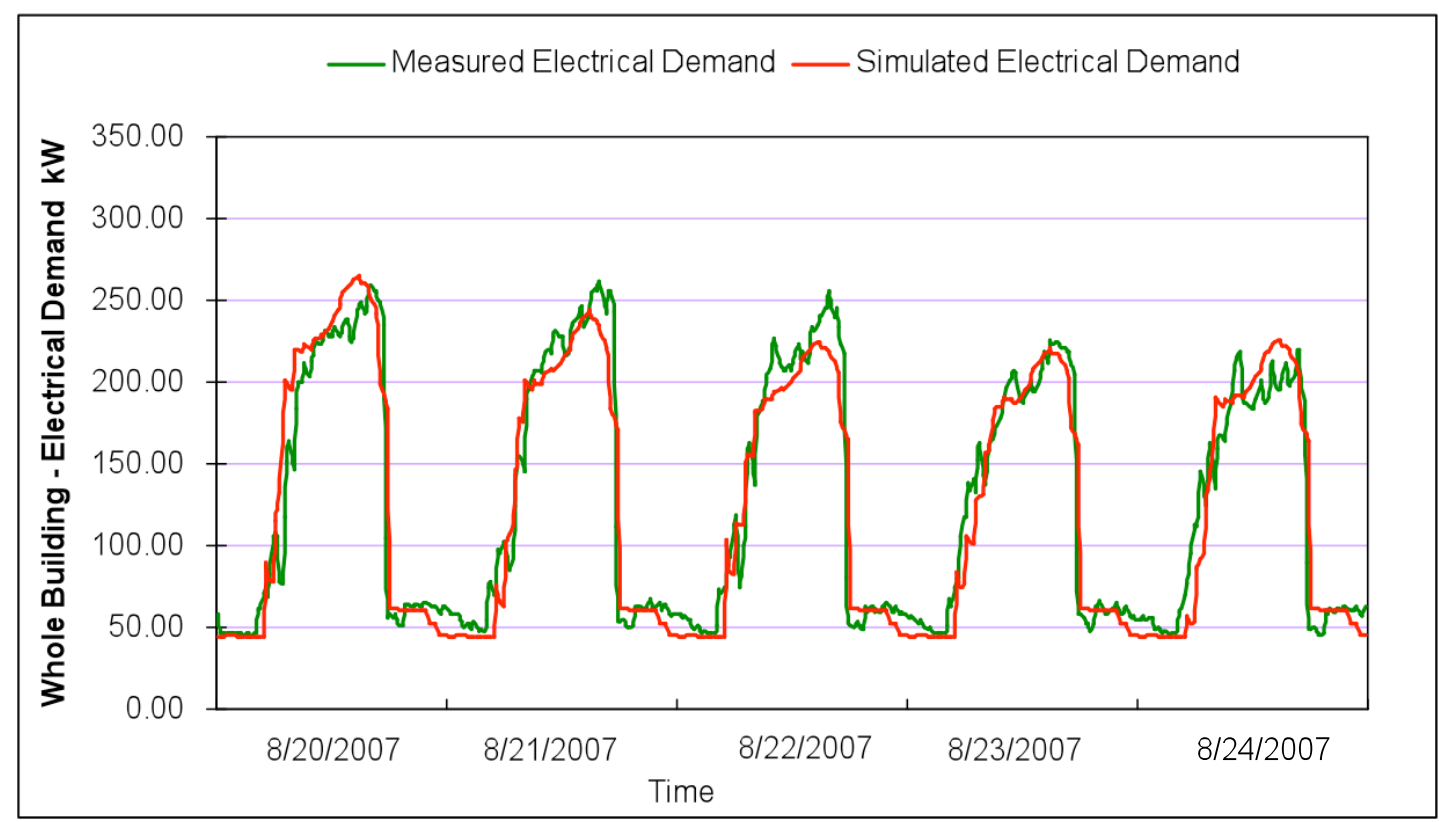

Figure 6: Daily Electrical Consumption of Simulation Model vs. Actual Electrical Consumption in August

\section{COMPARISO N OF HOURLY MEASURED DATA}

Because the internal loads such as lighting and plug loads could be slightly higher or lower compared to the normal operation on any given days, the data of two typical 
days in summer was selected to illustrate the accuracy of the simulation model. Figure 7 and Figure 8 show the comparison of the hourly whole building electrical demand between the calibrated simulation and the measured data. The calibration met the requirements of the ASHRAE standard - within $\pm 20 \%$ for a minimum of 20 hours out of 24 hours for each day. Figure 7 and Figure 8 indicate that the simulation results matched well to the measured data within $\pm 15 \%$.

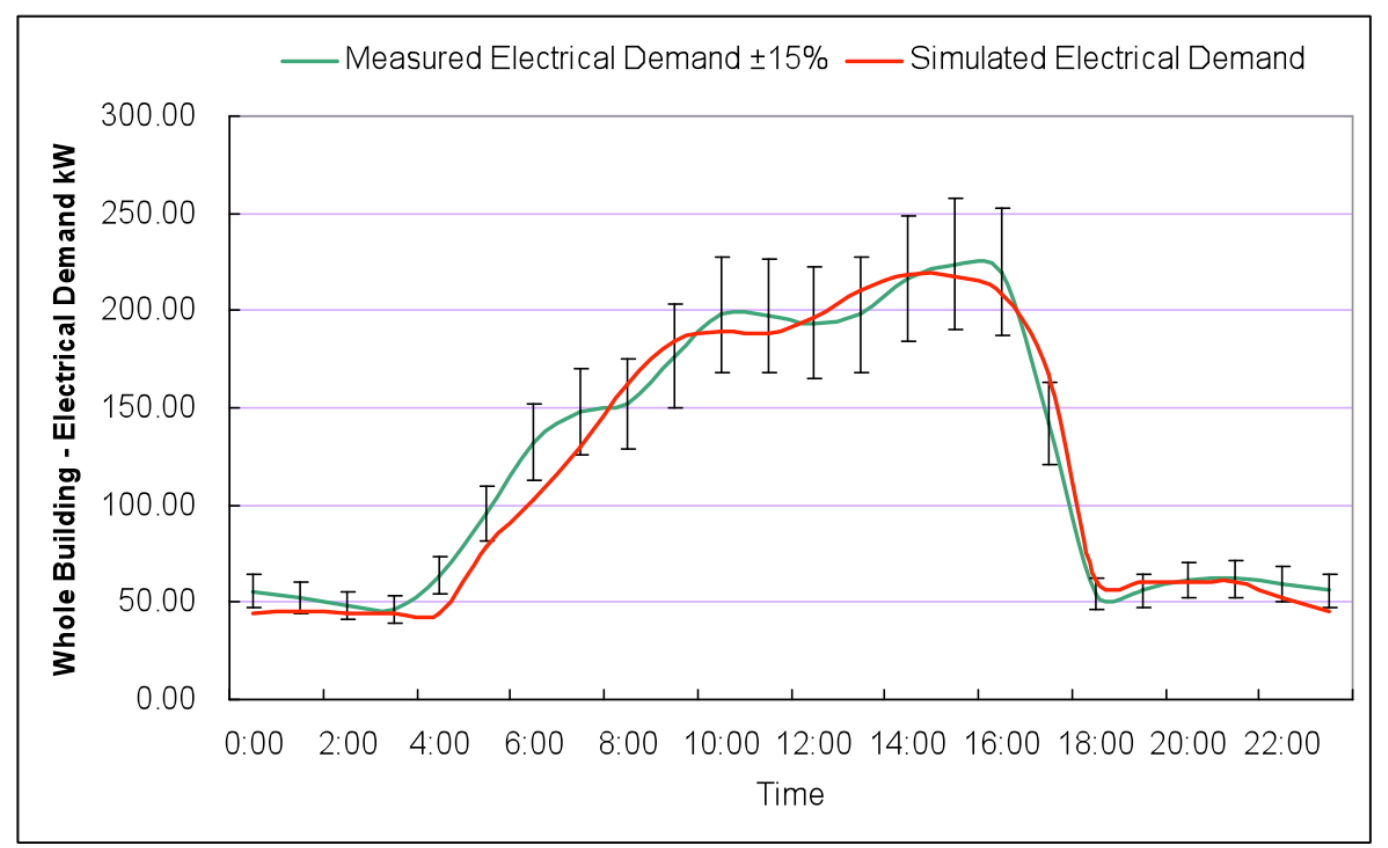

\section{Figure 7: Hourly Electrical Consumption of Simulation Model vs. Actual Electrical} CONSUMption One day in August

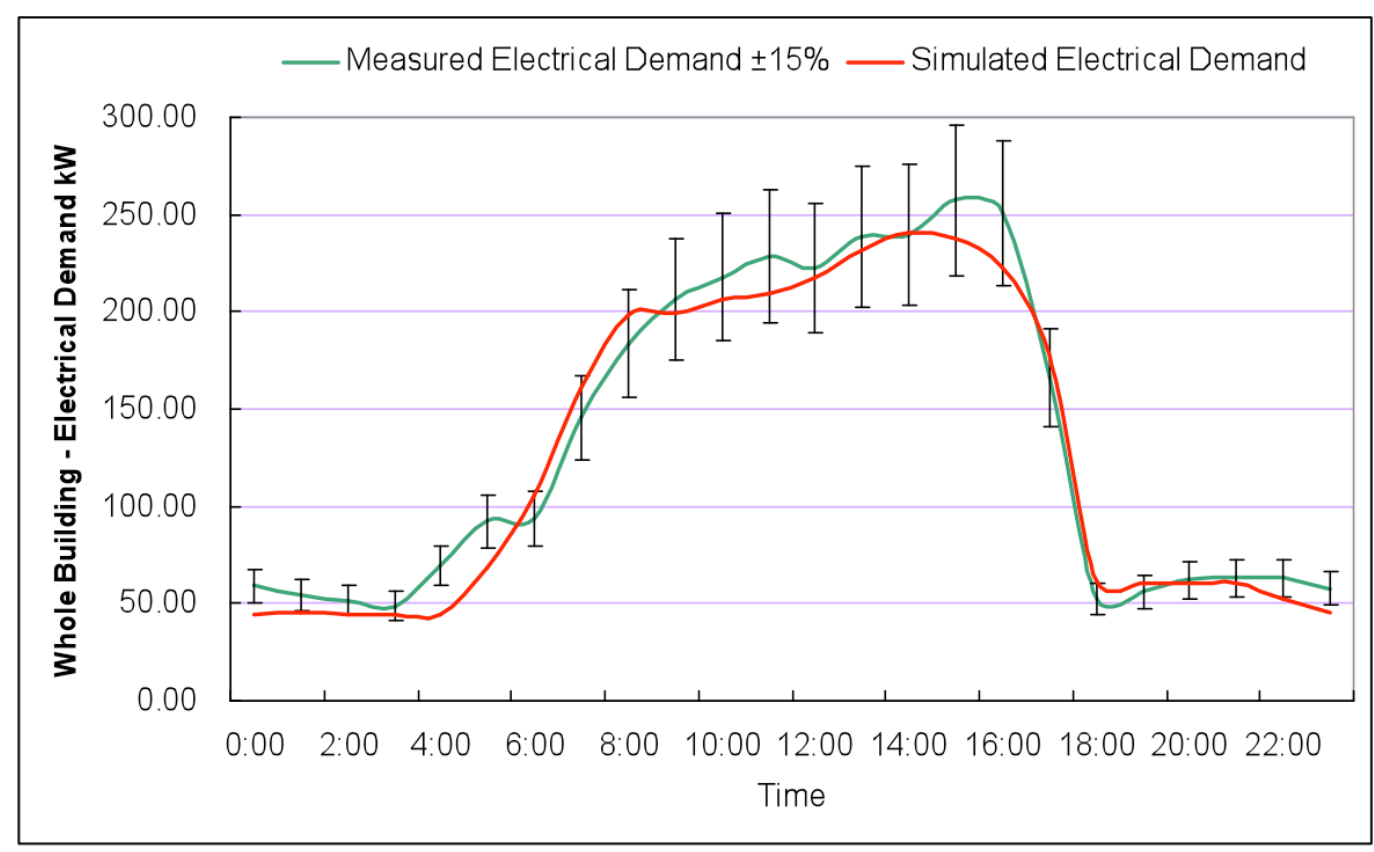

Figure 8: Hourly Electrical Consumption of Simulation Model vs. Actual Electrical CONSUMption One day in August 


\section{SUMMARY}

The initial simulation models for the buildings generated from the basic building information were not able to predict the load profiles of the buildings within a reasonable range of accuracy. However, the refined models after adjusting the internal load schedules predicted the load profiles of the buildings within $\pm 5 \%$ range. A standard procedure of model development and calibration was developed. The procedure takes the following steps:

- Generate a DRQAT initial model with basic building information

- Replace the TMY weather file in DRQAT and regenerate a .epw EnergyPlus file with real weather data collected from the site or the nearby weather stations

- Use whole building power under the extreme cold weather conditions to estimate the actual internal load schedule. The method will not work when electricity or heat pumps were used as heating sources

- Conduct simulation and compare the simulated result with the measure ones

- Readjust the internal loads until the measured electricity data match the simulated ones

The internal load had the largest impact on the accuracy of the building simulations when the basic building descriptions were accurate. However, it was hard to get the actual energy usage of the lighting and plug loads without historical data. For more accurate modeling, users should sub-meter end uses in the building for one or two weeks (weekdays) to separate out the internal and lighting electricity use from the HVAC electricity usage. Models generated from this procedure will be able to predict building electricity demand profile very accurately. 


\title{
Optimization of Pre-cooung Strategies
}

\section{Optimal Pre-cooung Strategies}

\author{
When to PRE-COOL: CPP Versus Non-CPP?
}

CPP (Critical Peak Pricing) days are called by the utility and tend be the 12 hottest days throughout the summer period. Normally, peak demand occurs on CPP days due to the high outside air temperature. Utility analyses were conducted to determine the strategy that could offer the highest economic savings to the building owner. From previous experience with similar buildings in this region, often the CPP incentives were not large enough to obtain enough demand charge savings and thus the owners may want to just use the pre-cooling strategies to reduce the peak demand in the summer months.

The utility charge includes energy charge, demand charge, customer charge and other charges. The energy and demand charges account for the majority of the total utility charge. The demand charge is the time-related demand charge per month, which is proportional to the monthly maximum demand. Customers can achieve economic savings by decreasing the monthly maximum demand. Therefore, it is recommended that the customers run the demand response strategies for a number of hot weather days.

The distribution of daily maximum demand throughout the summer period was different for each building in Tri-City Corporate Center. One goal of this analysis was to figure out whether to operate pre-cooling strategy throughout the summer period or only on hot days and determine how much demand charge could be reduced on test days under reasonable zone temperature reset strategy.

Figure 9 shows the distribution of daily peak demand on weekdays of the building tested in summer 2007. The peak demand was $339 \mathrm{~kW}$, and the peak outside air temperature was $108^{\circ} \mathrm{F}$. In order to reduce the demand charge, operators need to run the pre-cooling strategy on hot days throughout the summer period, but not on cool days. The data points in the left rectangle in Figure 9 indicate that the peak demand were lower than $250 \mathrm{~kW}$ when the peak outside temperature was below 90 ${ }^{\circ} \mathrm{F}$. Data in the right rectangle illustrate higher peak demand on the hot days. Since the goal of the optimization was to reduce the peak demand of the summer months and the difference between the peak demand on hot days and warm days was about $50 \sim 70 \mathrm{~kW}$, operators should run pre-cooling only in these right rectangular days. 


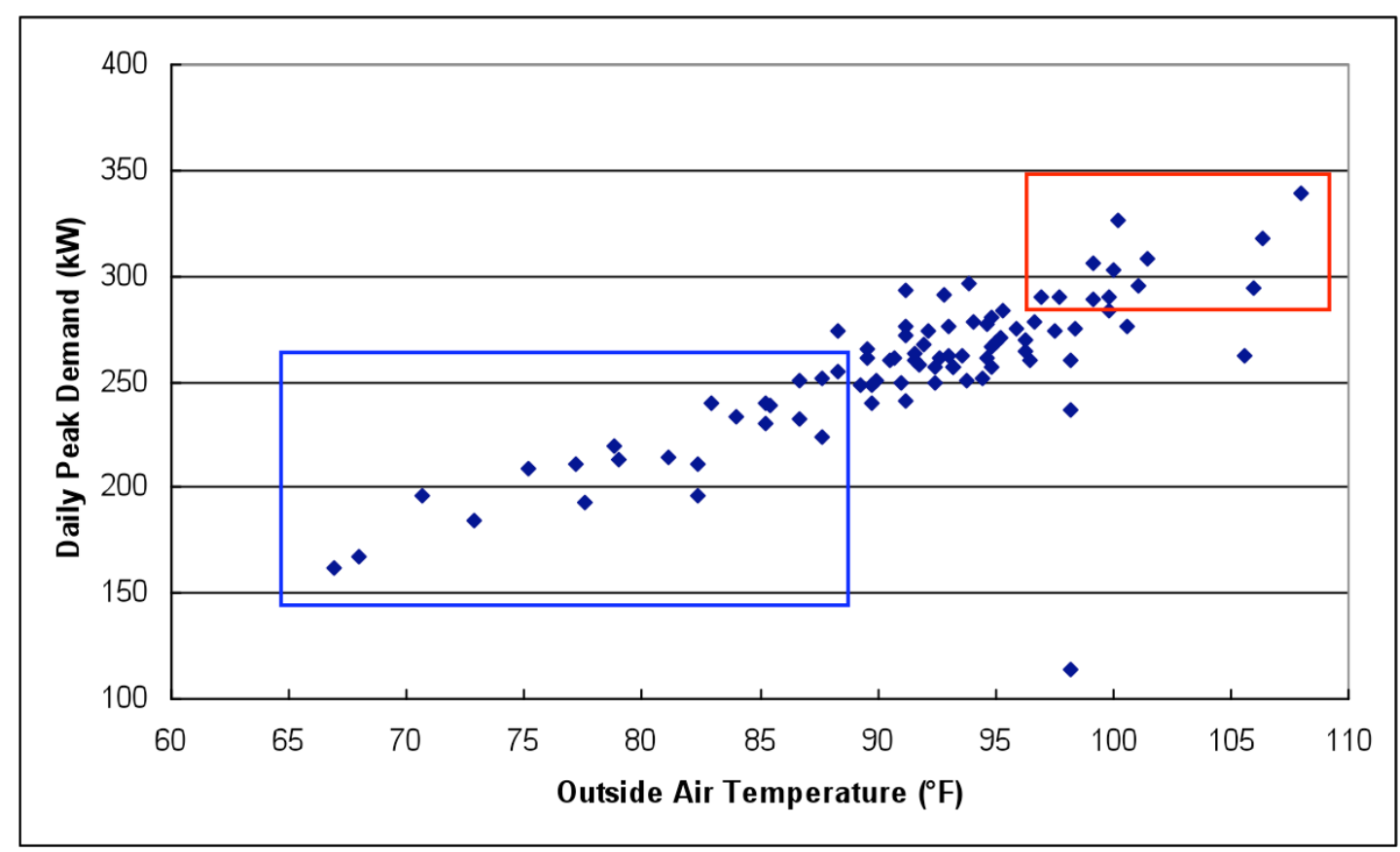

Figure 9: Distribution of Daily Max Demand throughout Summer Period-Three Carnegie PLAZA

Figure 10 shows the distribution of daily maximum demand for "One Vanderbilt" office building. No large difference in daily maximum demand was observed when the outside temperature exceeded $90^{\circ} \mathrm{F}$. If customers apply the demand response strategies in the building on the twelve hottest days only, the monthly utility charge would not be reduced much because the monthly maximum demand was still very high on Non-CPP days. Therefore, in order to achieve maximum energy and demand charge savings, the operator should run the demand response strategy every day when the weather was hot.

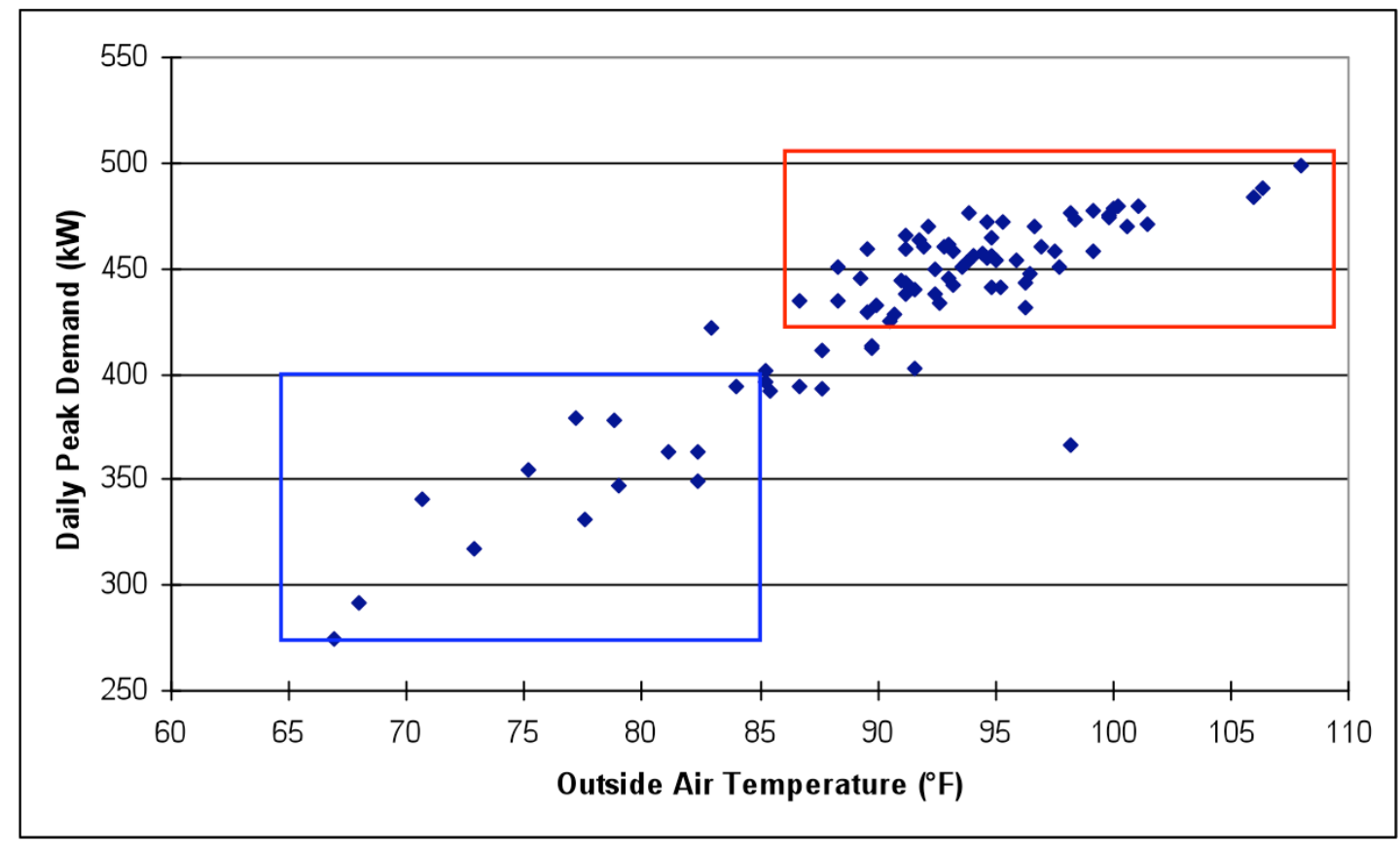




\section{Figure 10: Distribution OF DAILY MAX DEMAND throughoUt SUMMER PERIOD-ONE}

\section{VANDERBILT}

\section{Pre-CoOung StRAtegies}

The pre-cooling and zone temperature reset strategies evaluated in this study are shown in Figure 11. According to the trended operational data, all of these buildings were normally operated at constant temperature set points near $77^{\circ} \mathrm{F}$ throughout the warm-up and occupied hours. The set points in individual zones ranged from 75 to $80^{\circ} \mathrm{F}$, with an average value of about $77^{\circ} \mathrm{F}$. After $6 \mathrm{pm}$, the system was shut off and zone temperatures started to float.

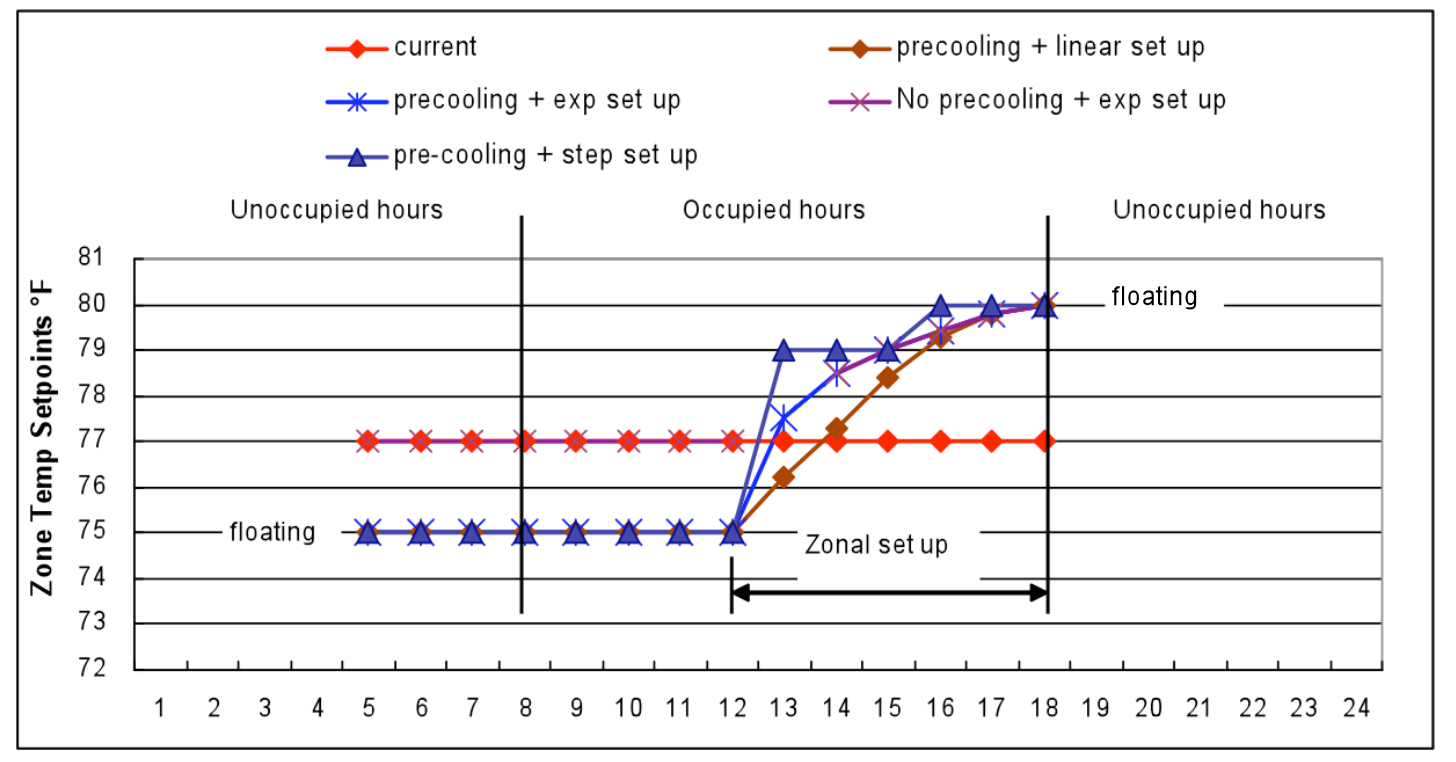

\section{Figure 11: Pre-cooling and Zone Temperature Reset Strategies}

The "pre-cooling + linear set up" strategy was the first strategy evaluated. From 5 am to $12 \mathrm{pm}$, mostly during the occupied hours, all of the zone temperature set points were reduced to $75^{\circ} \mathrm{F}$. From $12 \mathrm{pm}$ to $6 \mathrm{pm}$ (the high price period) the set points were raised linearly to $80^{\circ} \mathrm{F}$. After $6 \mathrm{pm}$, before the system was shut off, the set points were rolled back to $77^{\circ} \mathrm{F}$.

The second strategy was the "pre-cooling + exponential set up" strategy. While the pre-cooling period was same as for the first strategy, the temperatures were raised exponentially rather than linearly during the afternoon high price period.

The third strategy was the "no pre-cooling + exponential set up" strategy. The zone temperatures were raised exponentially in the afternoon in the same way as in the "pre-cooling + exponential set up" strategy, but without pre-cooling from 5 am to 12 am. One aim of the tests was to determine the effect of pre-cooling on peak demand shedding.

The fourth strategy was the "pre-cooling + step set up" strategy. The zone temperature set points were reduced to $75^{\circ} \mathrm{F}$. From $12 \mathrm{pm}$ to $3 \mathrm{pm}$, the set points were raised to $79^{\circ} \mathrm{F}$. After $3 \mathrm{pm}$, the zone temperature set points were kept at 80 ${ }^{\circ} \mathrm{F}$. 


\section{Simulation RESUltS Of Pre-COOUNg StRATEgies}

Simulations were conducted for the four different pre-cooling strategies. Figure 12 shows the simulation results of the different pre-cooling strategies for one office building. The plot illustrates the demand shed during the high price period. The "Precooling with step temp set up" strategy load profile was much flatter than the others. Of the other three strategies, the "Pre-cooling with exponential temp set up" strategy load profile was better than those of the "No pre-cooling with exponential temp set up" and "Pre-cooling with linear temp set up" strategies. The "Pre-cooling with linear temp set up" strategy load profile fluctuated throughout the zonal temp reset period and the shed was smaller than that of "exponential set up" strategy.

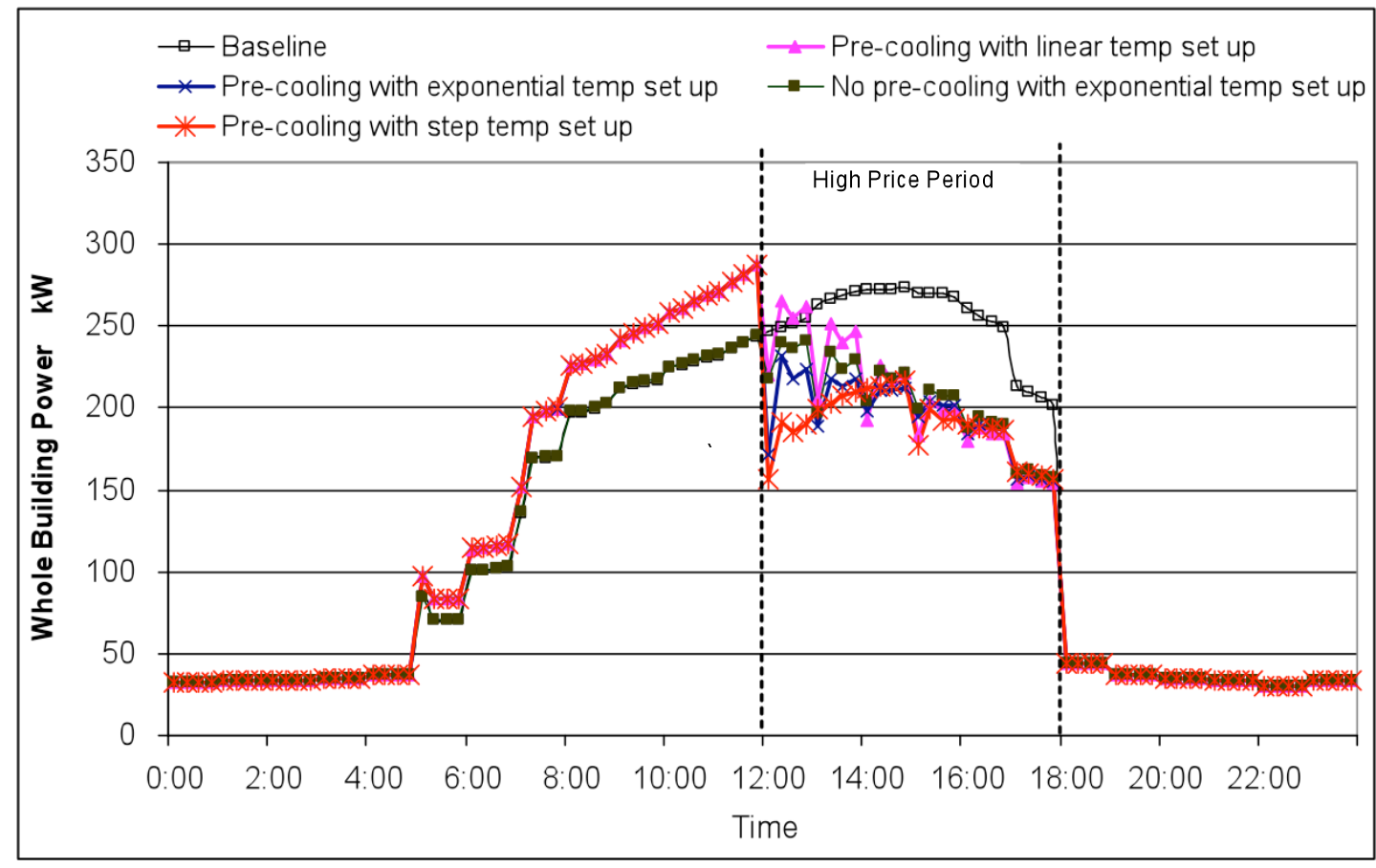

\section{Figure 12: Simulation Results of Pre-cooling Strategies}

\section{OptIMAL Pre-COOLNG StRATEgIES}

A series of simulations were conducted. The calibrated simulation models were used to find the optimal pre-cooling strategies for the eleven buildings. The optimal strategies were later tested in the buildings.

Due to the relative stability of their load profiles, the "Pre-cooling with exponential temp set up" and "Pre-cooling with step temp set up" strategies were determined to be the optimal strategies for the Tri-City Corporate Center buildings. The "pre-cooling with step temp set up" strategy was implemented during the field tests as this strategy is easier to implement and results in a flat load profile at the beginning of the on-peak period. Figure 13 shows the simulation results of pre-cooling strategies "Pre-cooling with exponential temp set up" and "Pre-cooling with step temp set up". From $12 \mathrm{pm}$ to $3 \mathrm{pm}$, zone temperature set points were raised to $79^{\circ} \mathrm{F}$. From $3 \mathrm{pm}$ to $6 \mathrm{pm}$, zone temperatures were kept at $80^{\circ} \mathrm{F}$. 


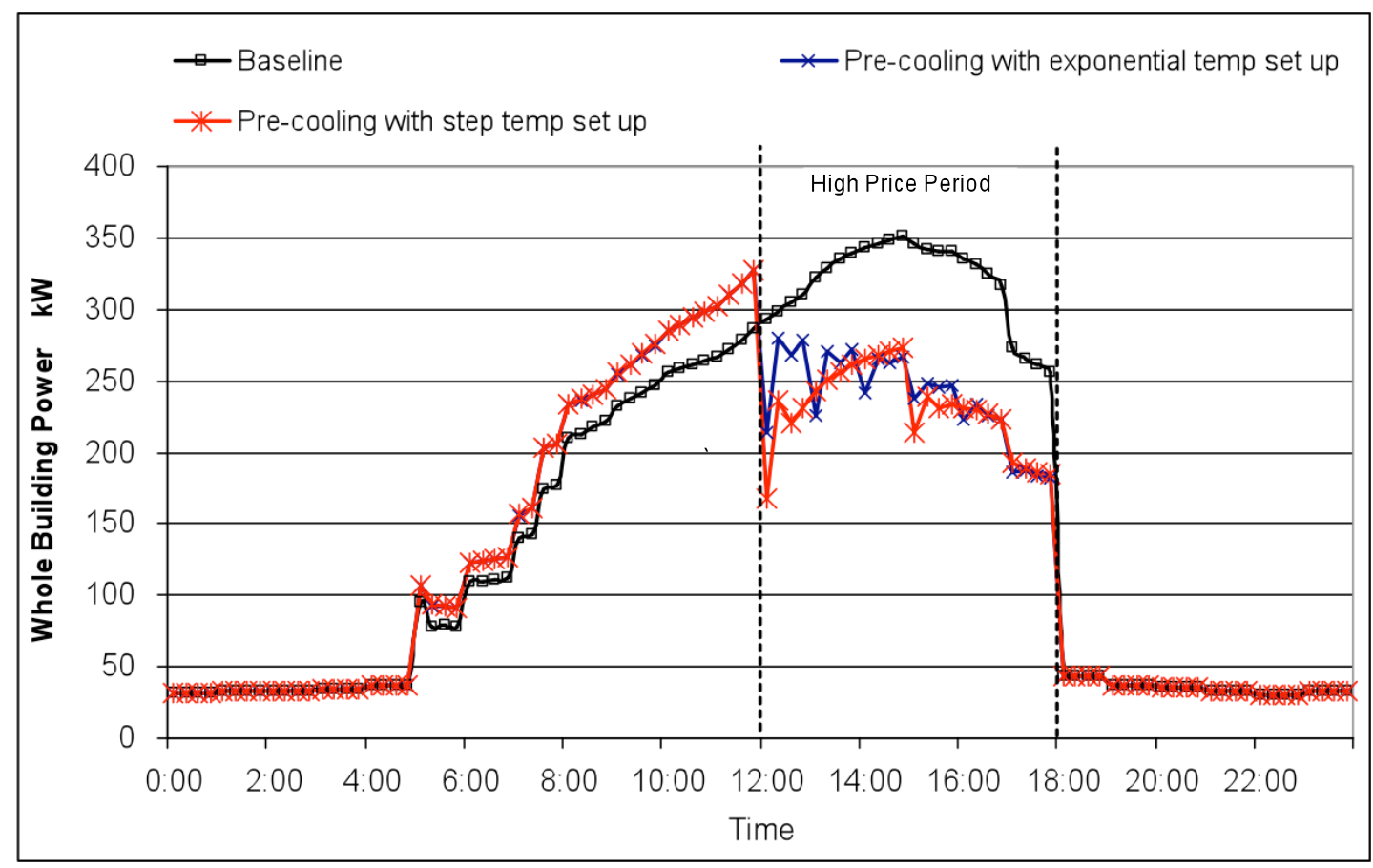

\section{Figure 9: Simulation Results of Optimal Pre-cooling Strategies}

Table 8 presents the comparison of the simulation results for two types of precooling strategies. The results indicate that the demand shed for these two precooling strategies were similar during the high price period. The peak demand shedding for "Pre-cooling with exponential temp set up" was higher than that of "Pre-cooling with step temp set up" by $15 \mathrm{~kW}$ due to the exponential temperature reset. However, the average demand shedding of "Pre-cooling with step temp set up" strategy was larger than that of the "Pre-cooling with exponential temp set up" strategy. The simulation results of "Pre-cooling with step temp set up" strategy seems to have a flatter load profile at the beginning of demand response period. Therefore, "Pre-cooling with step temp set up" strategy is recommended to be the more optimal pre-cooling strategy. As a rule of thumb, the operators should run the strategy whenever the peak outdoor temperatures are higher than $90^{\circ} \mathrm{F}$.

\section{Table 8: Simulation Results of Different Pre-cooling Strategies}

\begin{tabular}{|c|c|c|c|c|c|c|}
\hline \multirow{2}{*}{ Strategy } & \multicolumn{2}{|c|}{$\mathbf{k W}$} & \multicolumn{2}{|c|}{$\mathrm{W} / \mathrm{FT}^{2}$} & \multicolumn{2}{|c|}{ WBP\% } \\
\hline & MAX & Ave & MAX & Ave & MAX & Ave \\
\hline Pre-cooling with exponential temp set up & 122.05 & 65.96 & 1.46 & 0.79 & $37 \%$ & $20 \%$ \\
\hline Pre-cooling with step temp set up & 107.30 & 68.88 & 1.28 & 0.82 & $36 \%$ & $23 \%$ \\
\hline
\end{tabular}

\section{SUMMARY OF SIMULATION RESULTS}

Table 9 presents a summary of the simulation results for "pre-cooling with step temp set up" strategy in one office building (Three Carnegie Plaza). The average demand shed throughout the on-peak period was $44 \mathrm{~kW}$ and the peak demand shed ranged from $31 \mathrm{~kW}$ to $136 \mathrm{~kW}$. The average demand saving was over $15 \%$ with this precooling strategy. 


\section{Table 9: Simulation Results of Optimal “Step Temperature Set Up” Pre-cooling Strategy (Three Garnegie Plaza)}

\begin{tabular}{|c|c|c|c|c|c|c|c|}
\hline \multirow[t]{2}{*}{ EVEnT } & \multirow[t]{2}{*}{ PERIOD } & \multicolumn{2}{|c|}{$\mathbf{K W}$} & \multicolumn{2}{|c|}{$\mathbf{W} / \mathrm{FT}^{2}$} & \multicolumn{2}{|c|}{ WBP\% } \\
\hline & & Max & Ave & MAX & Ave & MaX & Ave \\
\hline \multirow[t]{2}{*}{ CPP-1 } & Moderate Price (12 pm-3 pm) & 76.4 & 50.3 & 0.91 & 0.60 & $27 \%$ & $18 \%$ \\
\hline & High Price ( 3 pm-6 pm) & 33.6 & 27.0 & 0.40 & 0.32 & $12 \%$ & $10 \%$ \\
\hline \multirow[t]{2}{*}{ CPP-2 } & Moderate Price (12 pm-3 pm) & 65.3 & 43.3 & 0.78 & 0.52 & $26 \%$ & $17 \%$ \\
\hline & High Price ( 3 pm-6 pm) & 31.5 & 24.1 & 0.38 & 0.29 & $13 \%$ & $10 \%$ \\
\hline \multirow[t]{2}{*}{ CPP-3 } & Moderate Price (12 pm-3 pm) & 91.8 & 54.7 & 1.10 & 0.65 & $31 \%$ & $19 \%$ \\
\hline & High Price ( 3 pm-6 pm) & 38.8 & 33.4 & 0.46 & 0.40 & $13 \%$ & $11 \%$ \\
\hline \multirow[t]{2}{*}{ CPP-4 } & Moderate Price (12 pm-3 pm) & 95.2 & 57.1 & 1.14 & 0.68 & $31 \%$ & $19 \%$ \\
\hline & High Price ( 3 pm-6 pm) & 43.2 & 34.4 & 0.52 & 0.41 & $14 \%$ & $11 \%$ \\
\hline \multirow[t]{2}{*}{ CPP-5 } & Moderate Price (12 pm-3 pm) & 135.9 & 73.6 & 1.62 & 0.88 & $40 \%$ & $22 \%$ \\
\hline & High Price ( 3 pm-6 pm) & 46.7 & 35.1 & 0.56 & 0.42 & $14 \%$ & $10 \%$ \\
\hline \multirow[t]{2}{*}{ CPP- 6} & Moderate Price (12 pm-3 pm) & 133.7 & 68.1 & 1.60 & 0.81 & $41 \%$ & $21 \%$ \\
\hline & High Price ( 3 pm-6 pm) & 38.8 & 30.3 & 0.46 & 0.36 & $12 \%$ & $9 \%$ \\
\hline \multirow[t]{2}{*}{ CPP-7 } & Moderate Price (12 pm-3 pm) & 133.2 & 65.8 & 1.59 & 0.79 & $40 \%$ & $20 \%$ \\
\hline & High Price ( 3 pm-6 pm) & 44.7 & 34.8 & 0.53 & 0.42 & $14 \%$ & $11 \%$ \\
\hline \multirow[t]{2}{*}{ CPP-8 } & Moderate Price (12 pm-3 pm) & 121.6 & 63.4 & 1.45 & 0.76 & $38 \%$ & $20 \%$ \\
\hline & High Price ( 3 pm- 6 pm) & 43.1 & 33.7 & 0.51 & 0.40 & $14 \%$ & $11 \%$ \\
\hline \multirow[t]{2}{*}{ CPP-9 } & Moderate Price (12 pm-3 pm) & 91.7 & 51.5 & 1.10 & 0.62 & $33 \%$ & $19 \%$ \\
\hline & High Price (3 pm-6 pm) & 38.3 & 29.9 & 0.46 & 0.36 & $14 \%$ & $11 \%$ \\
\hline \multirow[t]{2}{*}{ CPP- 10} & Moderate Price (12 pm-3 pm) & 96.5 & 56.5 & 1.15 & 0.68 & $34 \%$ & $20 \%$ \\
\hline & High Price ( 3 pm-6 pm) & 38.9 & 29.6 & 0.46 & 0.35 & $14 \%$ & $10 \%$ \\
\hline \multirow[t]{2}{*}{ CPP-11 } & Moderate Price (12 pm-3 pm) & 91.6 & 55.2 & 1.09 & 0.66 & $31 \%$ & $19 \%$ \\
\hline & High Price ( 3 pm-6 pm) & 37.5 & 29.2 & 0.45 & 0.35 & $13 \%$ & $10 \%$ \\
\hline \multirow[t]{2}{*}{ CPP-12 } & Moderate Price (12 pm-3 pm) & 88.7 & 53.4 & 1.06 & 0.64 & $31 \%$ & $19 \%$ \\
\hline & High Price ( 3 pm-6 pm) & 33.6 & 25.5 & 0.40 & 0.30 & $12 \%$ & $9 \%$ \\
\hline
\end{tabular}




\section{Pre-cooung fied TestAnalysis}

\section{Pre-CoOung AND DR EVEntFieId TEST Results}

\section{Pre-cooung Strategy field Test}

During Summer 2008, Global Energy Partner (GEP) implemented the "Pre-cooling with step temperature set up" strategy at each of the field sites, and conducted Auto-DR tests on the 12 DR events from July through September. Figure 14 shows the pre-cooling strategy used on the Auto-DR events days for the buildings.

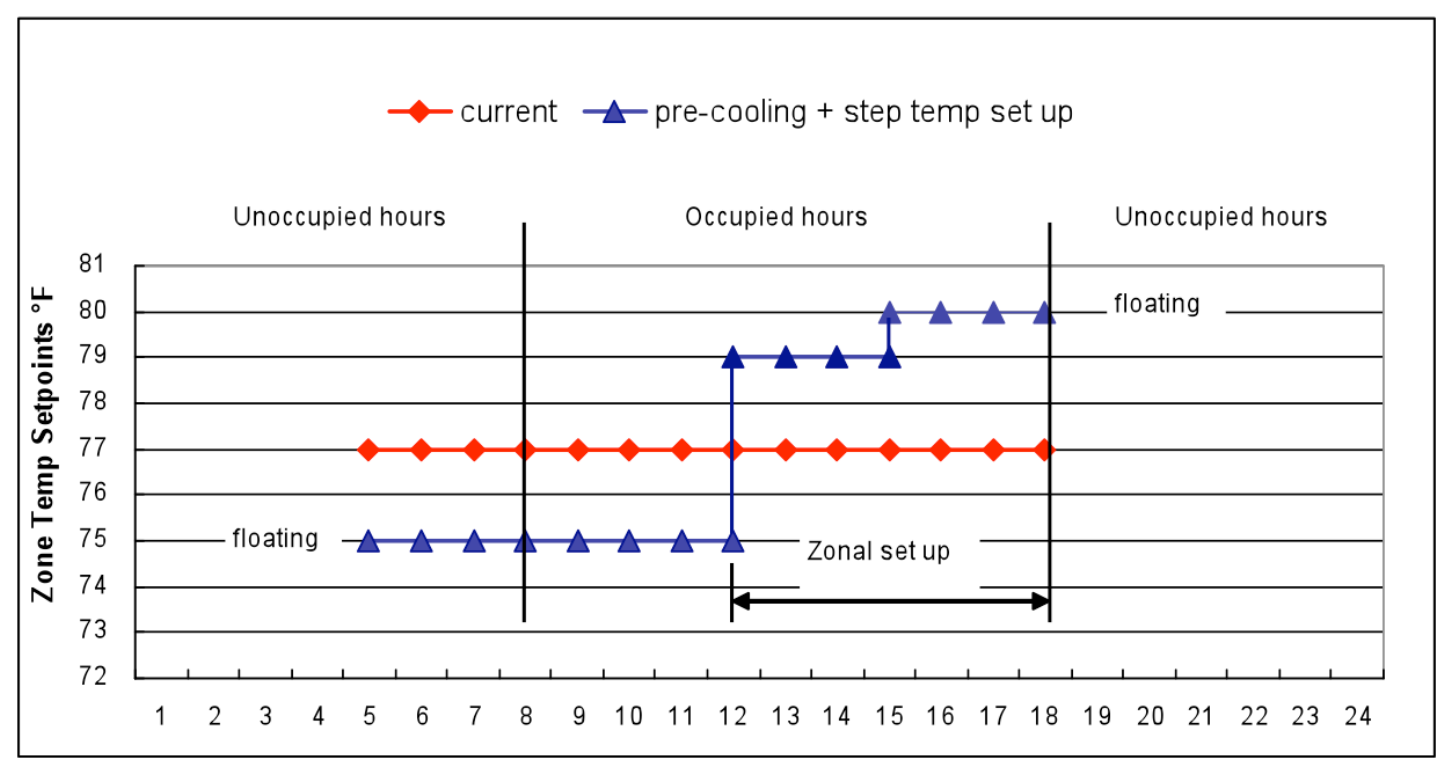

\section{Figure 10: Pre-cooling Strategies - Auto-DR}

\section{DREVENTFIED TEST}

\section{CONFIRMATION OF THE SIMULATION MODEL}

In the 2003 and 2004 studies, a strong correlation was observed between maximum outside air temperature and whole building peak power (Xu et al. 2004). In order to minimize the weather difference between simulations and test days, baseline days for each test day were selected based on the similarity in peak outside air temperatures and outside air temperatures profiles.

Simply comparing maximum outside air temperature is not a reliable method to select baselines. The average variance of hourly outside air temperatures (AVHOAT) between the baseline days and test days provide an additional metric that is calculated as: 
Equation 2: Average Variance of Hourly Outside Air Temperature

$$
\text { AVHOAT }=\frac{1}{24} \sum_{i=1}^{24}\left(B_{i}-T_{i}\right)^{2}
$$

$\mathrm{Bi}=$ the hourly outside air temperature for baseline days

$\mathrm{Ti}=$ the hourly outside air temperature for test days

Table 10 shows five potential baseline days that had similar maximum outside air temperatures to that of the 9/3/2008 test day. By only comparing the Peak OA Temperature, any of these five baseline days could be considered to be the best baseline day. The AVHOAT method, however, shows that 9/4/2008 had the smallest AVHOAT and thus would be the best match to use for the baseline day. As shown in Figure 15, the hourly outside air temperature on 9/4/2008 (the baseline day) were almost the same as on 9/3/2008 (Auto-DR day). This same method was used to select baseline days for the other CPP test event days.

\section{Table 10: Temperature Comparison between Baseline Days and Auto-DR Days}

\begin{tabular}{|l|r|r|r|r|r|r|}
\hline & $\begin{array}{l}\text { TEST } \\
\text { DAY }\end{array}$ & \multicolumn{5}{|c|}{ BASELI NE DAYS } \\
\hline Date & $9 / 3 / 08$ & $9 / 2 / 08$ & $9 / 4 / 08$ & $9 / 5 / 08$ & $9 / 15 / 08$ & $9 / 25 / 08$ \\
\hline Peak OA temperature $\left({ }^{\circ} \mathrm{F}\right)$ & 98.06 & 98.96 & 96.98 & 100.04 & 98.96 & 98.06 \\
\hline AVHOAT & - & 5.36 & 1.71 & 1.78 & 7.85 & 4.87 \\
\hline
\end{tabular}

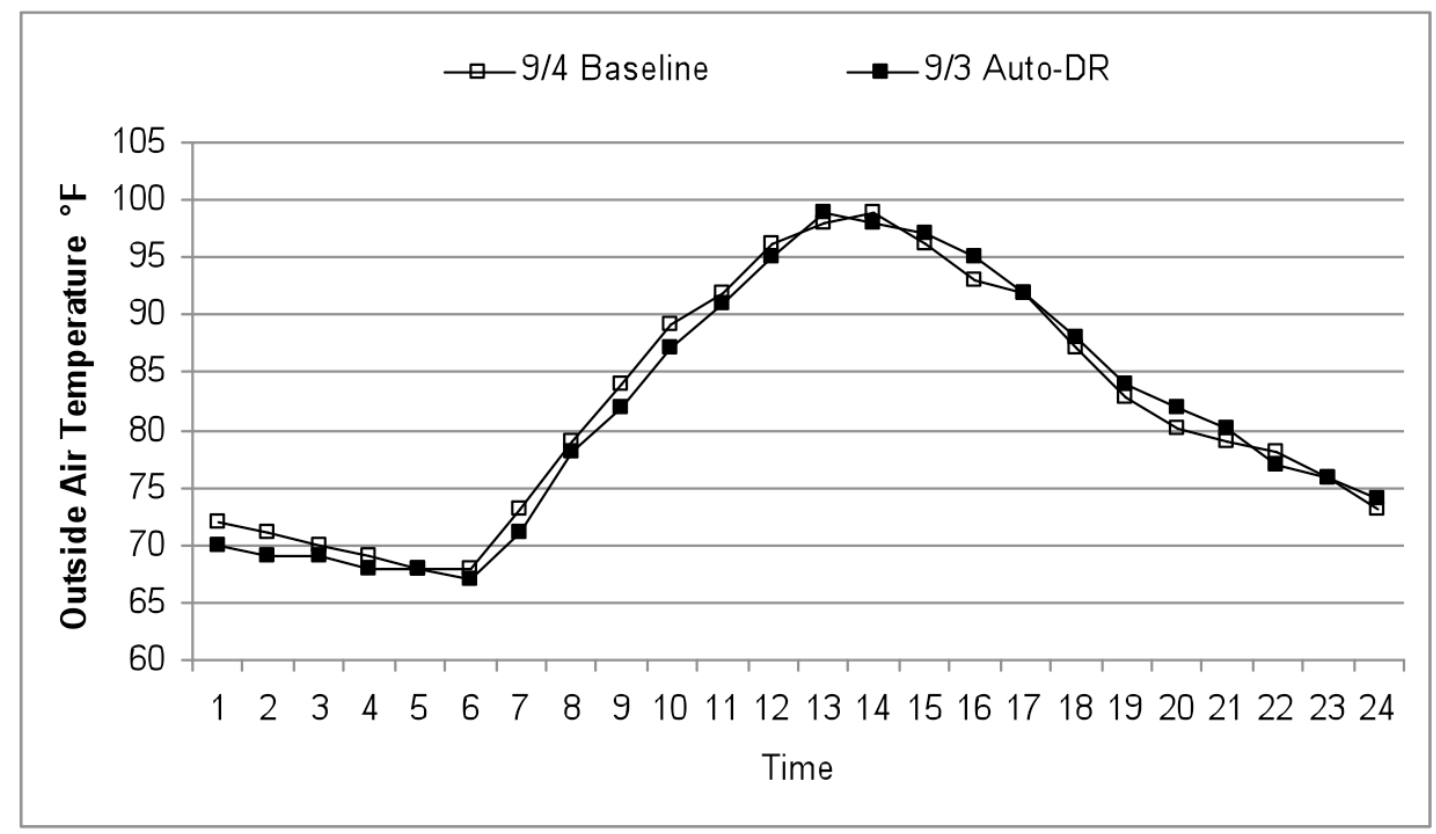

\section{Figure 11: Outside Air Temperature Comparison Between Baseline Day and Auto-DR DAY}

Table 11 presents a summary of the eleven critical peak pricing (CPP) event days their corresponding baseline days (note that pre-cooling field tests were conducted on eleven of the twelve possible CPP days). Results are provided for these eleven 
test days. The maximum outside air temperatures for the August CPP days were similar to each other.

\section{Table 11: Summary of Auto-DR days and Corresponding Baseline Days}

\section{NUMBer}

CPP-1

CPP-2

CPP-3

CPP-4

CPP-5

CPP-6

CPP-7

CPP-8

CPP-9

CPP-10

CPP-11
Date

$7 / 9 / 2008$
$7 / 10 / 2008$
$7 / 21 / 2008$
$8 / 1 / 2008$
$8 / 5 / 2008$
$8 / 6 / 2008$
$8 / 11 / 2008$
$8 / 12 / 2008$
$8 / 27 / 2008$
$8 / 28 / 2008$
$9 / 3 / 2008$

MAX OA TEMP

$92^{\circ} \mathrm{F}$

$93^{\circ} \mathrm{F}$

$93^{\circ} \mathrm{F}$

$98^{\circ} \mathrm{F}$

$96^{\circ} \mathrm{F}$

$96^{\circ} \mathrm{F}$

$97^{\circ} \mathrm{F}$

$97^{\circ} \mathrm{F}$

$92^{\circ} \mathrm{F}$

$91^{\circ} \mathrm{F}$

$99^{\circ} \mathrm{F}$
BASELI Ne

$7 / 14 / 2008$

$7 / 14 / 2008$

$7 / 14 / 2008$

$7 / 31 / 2008$

$8 / 7 / 2008$

$8 / 7 / 2008$

$8 / 15 / 2008$

$8 / 15 / 2008$

$8 / 19 / 2008$

$8 / 19 / 2008$

$9 / 4 / 2008$

\section{LBNL BASELINE MODEL}

LBNL developed a baseline model to estimate the demand saving from implementing the DR strategies. Previous research recommended a weather sensitive baseline model with adjustments for morning load variations. With respect to the LBNL baseline model, the whole building power baseline is estimated using a regression model that assumes that whole building power is linearly correlated with outside air temperature (OAT) (Coughlin, Piette et al, 2008).

Equation 3: Computed Baseline Model

$L_{i}=a_{i}+b_{i} T_{i}$

Where $L_{i}$ is predicted 15-minute interval electric demand for time $i$ from the previous non-CPP work days, $a_{i}$ and $b_{i}$ are estimated parameters generated from a linear regression of the input data for time $i . T_{i}$ is the hourly or 15-minute interval outside air temperature of time $i$.

Ten non-DR days were selected to develop the baseline electric loads for the demand savings, and these 10 baseline days were non-weekend, non-holiday Monday through Friday workdays.

The morning power load was used to adjust the regression model. The regression model is multiplied by the average ratio between the actual demand and the predicted demand from 9 am to noon, as shown in Equation 4. 
Equation 4 : Regression Model With Morning Load Adjustment

$L_{i}^{\prime}=P L_{i}$

$P=\operatorname{Average}\left(M_{i} / L_{i}\right)$

Where $L_{i}^{\prime}$ is the adjusted load for time $i, P$ is the calibration ratio, and $M_{i}$ is the actual demand for time $i$.

Based on the analysis of multiple baselines using the 2004 Auto-DR tests, the OAT regression model with morning load shape adjustment provided a better estimate than the OAT regression model without the morning load shape adjustment. The demand savings on Auto-DR days between the baseline model (AVHOAT) and the LBNL baseline model were compared. The results are listed in Appendix D (Figures D1-11). There was no significant difference between these two baseline models due to the similarity between the selected baseline days and the Auto-DR days.

\section{DR EVENTFEED TESTRESULTS}

"Three Carnegie Plaza" was again selected as the example to illustrate the precooling strategy field test results. This building participated in the 2008 critical peak pricing program. Figure 16 shows the whole building power measurement for the "LBNL baseline", the "9/4 Baseline" and the 9/3/2008 CPP event day with the "precooling with step temp set up" strategy. During the pre-cooling period ( 6 am to 12 $\mathrm{pm}$ ) on the CPP day, the electricity demand was higher than on the baseline days. The electricity demand was reduced by as much as $64 \mathrm{~kW}$ from $12 \mathrm{pm}$ to $6 \mathrm{pm}$. No rebound was observed before $6 \mathrm{pm}$. Notwithstanding the slight difference due to the adjustment of the LBNL baseline between 2 and 4 am, Figure 16 shows that the 9/4 baseline model load profile was similar to that of the LBNL baseline model. See Appendix $D$ for results for the other buildings.

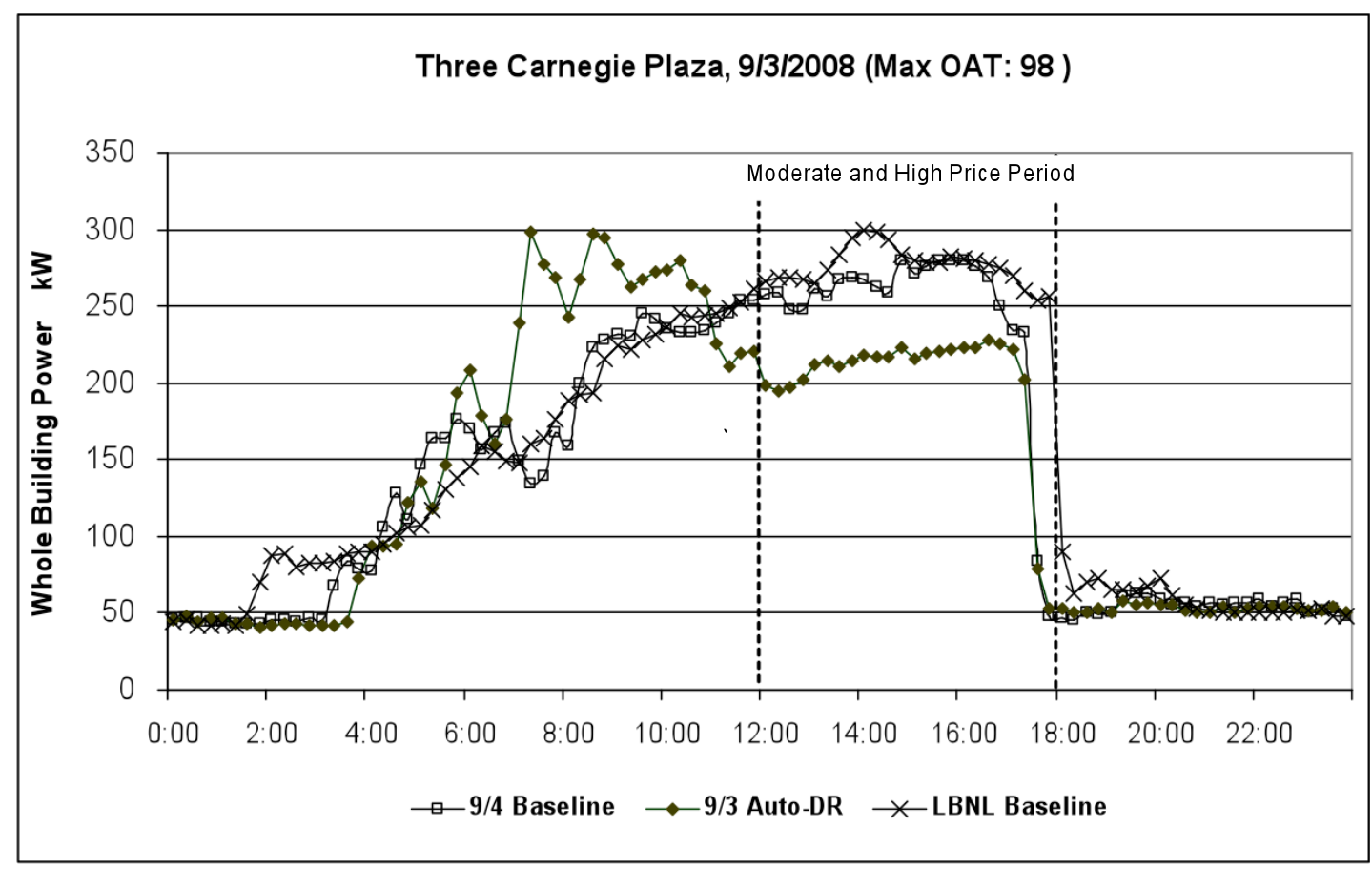




\section{Figure 12: Field Test Results of Pre-cooling Strategies on Auto-DR Day}

The field test results in Table 12 show significant peak demand savings for "Precooling with step set up" strategy throughout CPP days in the office building (Three Carnegie Plaza). Prior to the beginning of the CPP events, GEP conducted a short pre-cooling field test, however, the peak demand reduction was small. After they implemented the optimal "pre-cooling with step temp set up" strategy, the average of the peak demand savings on CPP days was about $59 \mathrm{~kW}$, and the peak demand was reduced by as much as $36 \%$.

\section{Table 12: Summary of Auto-DR Field Test Results - Three Carnegie Plaza}

\begin{tabular}{|c|c|c|c|c|c|c|c|}
\hline \multirow{2}{*}{ DATE } & \multirow{2}{*}{ Period } & \multicolumn{2}{|c|}{$\mathbf{k W}$} & \multicolumn{2}{|c|}{$\mathbf{W} / \mathbf{F T}^{2}$} & \multicolumn{2}{|c|}{ WBP\% } \\
\hline & & MAX & Ave & MAX & Ave & MaX & Ave \\
\hline \multirow[t]{2}{*}{ CPP-1 } & Moderate Price ( $12 \mathrm{pm}-3 \mathrm{pm}$ ) & 56.6 & 24.6 & 0.68 & 0.29 & $24 \%$ & $10 \%$ \\
\hline & High Price ( 3 pm-6 pm) & 31.7 & -37.6 & 0.38 & -0.45 & $13 \%$ & $-16 \%$ \\
\hline \multirow[t]{2}{*}{ CPP-2 } & Moderate Price ( $12 \mathrm{pm}-3 \mathrm{pm}$ ) & 43.2 & 4.3 & 0.52 & 0.05 & $18 \%$ & $2 \%$ \\
\hline & High Price ( 3 pm-6 pm) & 48.0 & -23.2 & 0.57 & -0.28 & $20 \%$ & $-10 \%$ \\
\hline \multirow[t]{2}{*}{ CPP-3 } & Moderate Price ( 12 pm-3 pm) & 2.9 & -11.4 & 0.03 & -0.14 & $1 \%$ & $-5 \%$ \\
\hline & High Price ( 3 pm-6 pm) & 20.2 & -20.9 & 0.24 & -0.25 & $8 \%$ & $-9 \%$ \\
\hline \multirow[t]{2}{*}{ CPP-4 } & Moderate Price ( $12 \mathrm{pm}-3 \mathrm{pm}$ ) & 63.4 & 50.6 & 0.76 & 0.60 & $27 \%$ & $21 \%$ \\
\hline & High Price ( 3 pm-6 pm) & 68.2 & 51.6 & 0.81 & 0.62 & $29 \%$ & $22 \%$ \\
\hline \multirow[t]{2}{*}{ CPP-5 } & Moderate Price (12 pm-3 pm) & 69.1 & 54.5 & 0.83 & 0.65 & $27 \%$ & $21 \%$ \\
\hline & High Price ( 3 pm-6 pm) & 86.4 & 54.2 & 1.03 & 0.65 & $34 \%$ & $21 \%$ \\
\hline \multirow[t]{2}{*}{ CPP-6 } & Moderate Price ( $12 \mathrm{pm}-3 \mathrm{pm}$ ) & 71.0 & 50.5 & 0.85 & 0.60 & $28 \%$ & $20 \%$ \\
\hline & High Price ( 3 pm-6 pm) & 64.3 & 45.0 & 0.77 & 0.54 & $25 \%$ & $18 \%$ \\
\hline \multirow[t]{2}{*}{ CPP-7 } & Moderate Price (12 pm-3 pm) & 111.4 & 101.1 & 1.33 & 1.21 & $36 \%$ & $33 \%$ \\
\hline & High Price ( $3 \mathrm{pm}-6 \mathrm{pm})$ & 84.5 & 50.6 & 1.01 & 0.61 & $27 \%$ & $16 \%$ \\
\hline \multirow[t]{2}{*}{ CPP-8 } & Moderate Price ( 12 pm-3 pm) & 90.2 & 77.5 & 1.08 & 0.93 & $29 \%$ & $25 \%$ \\
\hline & High Price ( 3 pm-6 pm) & 66.2 & 32.8 & 0.79 & 0.39 & $21 \%$ & $11 \%$ \\
\hline \multirow[t]{2}{*}{ CPP-9 } & Moderate Price (12 pm-3 pm) & 82.6 & 66.1 & 0.99 & 0.79 & $28 \%$ & $22 \%$ \\
\hline & High Price ( 3 pm- 6 pm) & 72.0 & 56.4 & 0.86 & 0.67 & $25 \%$ & $19 \%$ \\
\hline \multirow[t]{2}{*}{ CPP-10 } & Moderate Price ( 12 pm-3 pm) & 74.9 & 59.2 & 0.89 & 0.71 & $25 \%$ & $20 \%$ \\
\hline & High Price ( 3 pm-6 pm) & 63.4 & 43.2 & 0.76 & 0.52 & $22 \%$ & $15 \%$ \\
\hline \multirow[t]{2}{*}{ CPP-11 } & Moderate Price ( 12 pm-3 pm) & 64.3 & 51.3 & 0.77 & 0.61 & $23 \%$ & $18 \%$ \\
\hline & High Price ( 3 pm-6 pm) & 58.6 & 37.2 & 0.70 & 0.44 & $21 \%$ & $13 \%$ \\
\hline
\end{tabular}




\section{COMPARISON OF ACTUALDATA AND SIMULATION PREDICTION}

The measured data in Table 12 was compared to the simulation results in Table 9. The average demand shed of the simulation models was slightly lower than the measured data. Among the DRQAT inputs, level of thermal mass had the largest impact on peak demand reductions. The building thermal mass level was set to "Medium" in the first calibrated models, which was confirmed according to the characteristics of typical office buildings. The comparison results illustrated that the thermal mass level of the actual building was higher than that in the simulation models. Therefore, the thermal mass level was reset to "High" in the adjusted models in some buildings.

\section{Table 13: Summary of Optimal Pre-cooling Strategy - Recalibrated Model}

\begin{tabular}{|c|c|c|c|c|c|c|c|}
\hline \multirow{2}{*}{ DATE } & \multirow{2}{*}{ Period } & \multicolumn{2}{|c|}{ kW } & \multicolumn{2}{|c|}{$\mathbf{W} / \mathrm{FT}^{2}$} & \multicolumn{2}{|c|}{ WBP\% } \\
\hline & & MAX & Ave & MAX & Ave & MAX & Ave \\
\hline \multirow[t]{2}{*}{ CPP-1 } & Moderate Price (12 pm-3 pm) & 79.3 & 48.9 & 0.95 & 0.58 & $28 \%$ & $17 \%$ \\
\hline & High Price ( 3 pm-6 pm) & 48.2 & 36.5 & 0.58 & 0.44 & $17 \%$ & $13 \%$ \\
\hline \multirow[t]{2}{*}{ CPP-2 } & Moderate Price (12 pm-3 pm) & 69.0 & 42.5 & 0.82 & 0.51 & $27 \%$ & $17 \%$ \\
\hline & High Price ( 3 pm- 6 pm) & 45.9 & 32.9 & 0.55 & 0.39 & $18 \%$ & $13 \%$ \\
\hline \multirow[t]{2}{*}{ CPP-3 } & Moderate Price ( $12 \mathrm{pm}-3 \mathrm{pm})$ & 95.5 & 53.4 & 1.14 & 0.64 & $32 \%$ & $18 \%$ \\
\hline & High Price ( 3 pm-6 pm) & 55.7 & 45.0 & 0.66 & 0.54 & $19 \%$ & $15 \%$ \\
\hline \multirow[t]{2}{*}{ CPP-4 } & Moderate Price ( $12 \mathrm{pm}-3 \mathrm{pm})$ & 99.2 & 56.1 & 1.19 & 0.67 & $32 \%$ & $18 \%$ \\
\hline & High Price ( 3 pm-6 pm) & 62.8 & 47.3 & 0.75 & 0.57 & $20 \%$ & $15 \%$ \\
\hline \multirow[t]{2}{*}{ CPP-5 } & Moderate Price ( $12 \mathrm{pm}-3 \mathrm{pm})$ & 138.1 & 71.4 & 1.65 & 0.85 & $39 \%$ & $20 \%$ \\
\hline & High Price ( 3 pm- 6 pm) & 68.3 & 48.6 & 0.82 & 0.58 & $19 \%$ & $14 \%$ \\
\hline \multirow[t]{2}{*}{ CPP-6 } & Moderate Price ( $12 \mathrm{pm}-3 \mathrm{pm}$ ) & 136.9 & 65.9 & 1.64 & 0.79 & $41 \%$ & $20 \%$ \\
\hline & High Price ( 3 pm- 6 pm) & 57.3 & 42.2 & 0.69 & 0.50 & $17 \%$ & $13 \%$ \\
\hline \multirow[t]{2}{*}{ CPP-7 } & Moderate Price ( $12 \mathrm{pm}-3 \mathrm{pm}$ ) & 132.2 & 62.0 & 1.58 & 0.74 & $39 \%$ & $18 \%$ \\
\hline & High Price ( 3 pm- 6 pm) & 62.9 & 45.3 & 0.75 & 0.54 & $18 \%$ & $13 \%$ \\
\hline \multirow[t]{2}{*}{ CPP-8 } & Moderate Price ( $12 \mathrm{pm}-3 \mathrm{pm})$ & 125.3 & 60.5 & 1.50 & 0.72 & $38 \%$ & $18 \%$ \\
\hline & High Price ( 3 pm- 6 pm) & 61.8 & 44.5 & 0.74 & 0.53 & $19 \%$ & $14 \%$ \\
\hline \multirow[t]{2}{*}{ CPP-9 } & Moderate Price ( $12 \mathrm{pm}-3 \mathrm{pm})$ & 96.1 & 50.9 & 1.15 & 0.61 & $34 \%$ & $18 \%$ \\
\hline & High Price ( 3 pm-6 pm) & 55.3 & 40.9 & 0.66 & 0.49 & $19 \%$ & $14 \%$ \\
\hline \multirow[t]{2}{*}{ CPP-10 } & Moderate Price ( $12 \mathrm{pm}-3 \mathrm{pm})$ & 101.3 & 55.5 & 1.21 & 0.66 & $35 \%$ & $19 \%$ \\
\hline & High Price ( 3 pm- 6 pm) & 55.7 & 40.3 & 0.66 & 0.48 & $19 \%$ & $14 \%$ \\
\hline \multirow[t]{2}{*}{ CPP-11 } & Moderate Price ( $12 \mathrm{pm}-3 \mathrm{pm})$ & 95.3 & 54.2 & 1.14 & 0.65 & $31 \%$ & $18 \%$ \\
\hline & High Price ( 3 pm- 6 pm) & 54.8 & 40.4 & 0.66 & 0.48 & $18 \%$ & $13 \%$ \\
\hline CPP-12 & Moderate Price ( $12 \mathrm{pm}-3 \mathrm{pm})$ & 92.3 & 52.2 & 1.10 & 0.62 & $32 \%$ & $18 \%$ \\
\hline
\end{tabular}




\begin{tabular}{ll|c|c|c|c|c|c} 
Date & Period & \multicolumn{2}{c}{$\mathbf{K W}$} & \multicolumn{2}{c}{$\mathbf{W} / \mathbf{F T}^{\mathbf{2}}$} & \multicolumn{2}{c}{$\mathbf{W B P} \%$} \\
\cline { 2 - 8 } & & Max & Ave & MAX & Ave & MAX & Ave \\
\hline High Price (3 pm-6 pm) & 48.7 & 35.2 & 0.58 & 0.42 & $17 \%$ & $12 \%$ \\
\hline
\end{tabular}

Appendix D (Tables D1-D11) present the calculated results of demand savings on Auto-DR days for all of the buildings, and Appendix E (Tables E1-E11) present the DRQAT simulated results of demand savings for each building. The field test results indicate that some buildings show little demand reduction on Auto-DR days, while the simulated results show the effectiveness of the demand response strategies on CPP days. One reason for the low amount of demand shed was the operation of the demand response strategy; the operators didn't adjust the temperature properly. Another reason was the selection of the baseline for each Auto-DR day. Two baseline models were calculated for each Auto-DR day: the first baseline model was selected based on the similarity of the outside air temperature between baseline days and Auto-DR days, and the second baseline model was calculated using a weather sensitive baseline model with adjustments for morning load variations (LBNL baseline model). By comparing these two baseline models to electricity loads on Auto-DR days, the LBNL baseline model was almost the same as the first baseline model.

For some buildings, the difference in energy usage for the lighting, plug and miscellaneous loads between the baseline days and Auto-DR days could lead to the inaccurate calculation of demand savings for the demand response strategy. More attention needs to be paid to these buildings, including sub-metering the electric usage of lighting, plug, and HVAC system, to find reasons for the little demand shed on Auto-DR days.

\section{SUMMARY}

The pre-cooling and CPP field tests results were analyzed, the energy and economic analyses were conducted, and the DRQAT models were readjusted with the test data. Baseline days for the CPP test days were selected based on the similarity of the outside air temperature between the baseline days and the test days. In selecting baseline days, effort was taken to match the maximum outside air temperature and also to minimize the hourly temperature difference between the baseline days and CPP test days.

The optimal pre-cooling strategy worked very well in the office buildings and was able to reduce the demand significantly (15 30\% throughout the summer period). The whole building power profiles on the CPP days indicated no rebound in the afternoon. The refined models can be used to predict the demand saving from other demand response strategies. 


\section{COMPARISON OF DRQATMTH EQUESTAND BEST}

Many building energy simulation tools have been developed to simulate building performance. These building energy simulation tools were used to simulate performance of building envelopes and HVAC systems to improve building design and operation. Building simulation models have also been used to establish DR baselines and calculate the energy and demand savings of DR strategies.

Features and capabilities of three building energy simulation tools were compared: Quick Energy Simulation Tool (eQUEST), Building Energy Simulation Tool (BEST), and Demand Response Quick Assessment Tool (DRQAT). All three tools are capable of simulating energy usage and predicting hourly building electric demand. However, because each software tool uses different calculation engines, they have different levels of accuracy and not all of them are suitable for simulating thermal mass effects.

\section{INTRODUCTION TO ENERGY SIMULATION TOOLS}

EQUEST is a sophisticated, yet easy to use, freeware building energy use analysis tool that provides professional- level results with an affordable level of effort. It was designed to allow users to perform detailed comparative analysis of building designs and technologies by applying sophisticated building energy simulation techniques but without requiring extensive experiences in the "art" of building performance modeling. It is accomplished by combining a building creation wizard, an energy efficiency measure (EEM) wizard and a graphic results display module with a complete DOE2.2 building energy use simulation program.

BEST is a building energy simulation tool linking DOE2.2 with custom building models. The tool is licensed to Global Energy Partners, LLC. Projects in BEST include CEC Demand Control, lowa Utilities and DEEM Project. The project "CEC Demand Control" implements Demand-Control measures for a range of commercial building types. Each building type has default values for 4 vintages (Very Old, Old, Recent and New) that vary with climate zones. The 16 Standard CEC weather files are installed in BEST.

DRQAT is a tool for simulating large commercial buildings DR strategies, developed by LBNL's Demand Response Research Center with funding from the California Energy Commission's PIER Program. This tool is based on EnergyPlus simulations of prototypical buildings and HVAC equipment. It incorporates prototypical buildings and equipment and requires the user to specify only a relatively small number of important parameters in order to run a quick assessment of DR strategies. DRQAT predicts energy and peak electrical demand savings, economic savings, and thermal comfort impacts of various demand response strategies. 


\section{FUNCTIONAUTY}

\section{GenerAL FeATuRES}

The general capabilities of eQUEST, BEST and DRQAT were compared (Table 14). eQUEST is the most sophisticated tool among all three. It can develop both simple and detailed building models integrated with many types of HVAC systems. Compared to eQUEST, BEST and DRQAT are developed only for predicting demand response savings. Both BEST and DRQAT are integrated with different demand response strategies, and can predict demand and energy savings quickly.

\section{Table 14: General Features of Building Energy Simulation ToOl}

\section{NDEX}

Simulation

Solution

\begin{tabular}{|c|c|}
\hline & temperature \\
\hline \multirow{2}{*}{$\begin{array}{l}\text { Time Step in } \\
\text { Hour }\end{array}$} & Hourly \\
\hline & $1 \sim 60$ in Hour \\
\hline \multirow{2}{*}{$\begin{array}{l}\text { Building } \\
\text { Geometry }\end{array}$} & Detailed and Flexible \\
\hline & Quick Modeling \\
\hline \multirow[t]{5}{*}{ Zone Load } & Internal load \\
\hline & Schedule flexibility \\
\hline & Internal Thermal Mass \\
\hline & Human Thermal Comfort \\
\hline & Design Day Sizing \\
\hline \multirow[t]{2}{*}{ HVAC System } & Types of HVAC System \\
\hline & System Sizing \\
\hline \multirow[t]{3}{*}{ Energy Cost } & Complex energy tariffs \\
\hline & $\begin{array}{l}\text { Detailed economic } \\
\text { analysis }\end{array}$ \\
\hline & Graphic output \\
\hline \multirow{5}{*}{$\begin{array}{l}\text { Results } \\
\text { Reporting }\end{array}$} & User defined report \\
\hline & Interface of report \\
\hline & Energy end-use \\
\hline & Peak demand \\
\hline & Quickly \\
\hline
\end{tabular}

\section{CAPABI LITY}

Sequential loads, system, plant calculations

Simultaneous loads,

Floating room temperature

$1 \sim 60$ in Hour system, plant calculations
EQUEST

$\mathrm{X}$

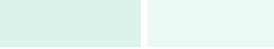

BEST

$\mathrm{X}$
DRQAT

X

$\mathbf{X}$

$\mathbf{X}$

$X$

$\mathbf{X}$

$\mathbf{X}$

$\mathbf{X}$

$\mathrm{X}$

$\mathbf{X}$

$\mathbf{X}$

$\mathrm{X}$

X

$\mathbf{X}$

$\mathbf{X}$

X

X

X

$\mathbf{X}$
$\mathbf{X}$

X

$\mathbf{X}$

$\mathbf{X}$

$\mathbf{X}$

$\mathbf{X}$

$\mathrm{X}$

$\mathbf{X}$

$\mathbf{X}$

X

X

$x$

$x$

$\mathbf{X}$

$\mathbf{X}$

X

$x$

$x$

$x$

$\mathrm{x}$

$x$

$x$

$x$

$\mathrm{X}$

$\mathrm{X}$ 


\section{Difference in BuILIINg DYNAMICs Prediction}

Figure 17 and Figure 18 show the load calculation procedures of DOE2 and EnergyPlus. DOE2 has one subprogram for translating input (BDL Processor), and four simulation subprograms (Loads, Systems, Plant and Economic). Loads, Systems and Plant are executed in sequence, with the output of Loads becoming the input to Economics. In contrast, EnergyPlus handles loads calculated (by a heat balance engine) and system simulation simultaneously at each time step, calculating heating and cooling system and plant and electrical system balance. This integrated solution provides more accurate space temperature prediction, which is crucial for system and plant sizing, occupant comfort and occupant health calculations. Therefore, Loads calculation in EnergyPlus fully accounts for thermal mass compared to DOE2. DOE2 does not fully capture the effect of the wall thermal mass in the load adjustment module.

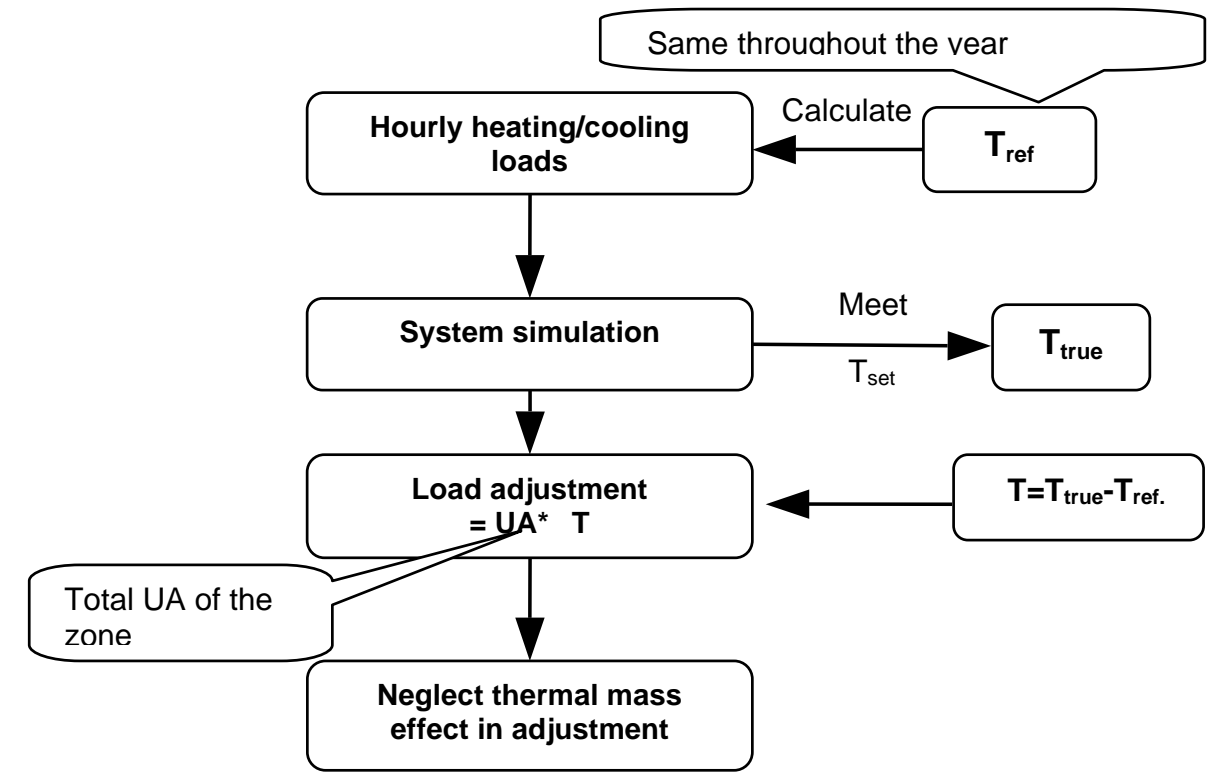

\section{Figure 13: DOe-2 loads Calculation Procedure}

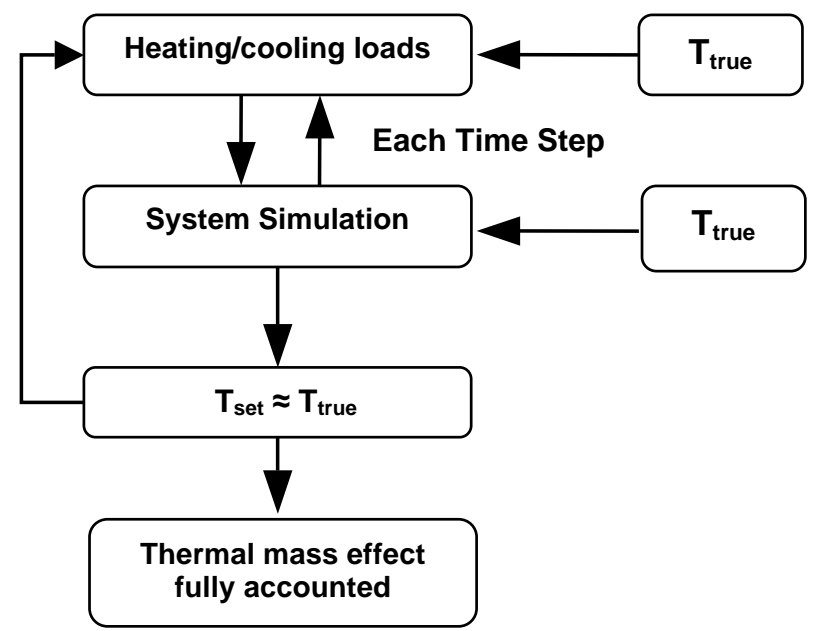

Figure 14: Energy Plus loads Calculation Procedure 


\section{COMPARISON OF SIMULATIONS WTH REAL BUIDING DATA}

Three office buildings ("Three Carnegie Plaza”, "Three Carnegie Plaza” and "Brier Corporate Center") were selected to compare these simulation tool's results for different DR strategies, pre-cooling, and thermal mass levels. The three simulation tools used the same building inputs for their simulation models.

\section{PRE-COOUNG STRATEGY}

BEST has three DR strategies that implement zone temperature reset, while eQUEST and DRQAT can run different zone temperature reset strategies. Because of BEST's limitation on the types of zone temperature reset strategies it could model and the fact that this strategy was implemented during the field tests in the buildings modeled, the "Pre-cooling step temp set up" DR strategy was simulated with eQUEST, BEST and DRQAT. Comparing the results between the simulation model and the measured data helped predict which simulation tools could better predict the energy usage and demand shed of real buildings.

Pre-cooling with exponential temperature set up. The zone temperatures were decreased in the morning as was done with the "pre-cooling with exponential temperature set up" strategy. In the afternoon, the zone temperature set points are raised exponentially to maximum of $4^{\circ} \mathrm{F}$.

Table 15 presents the simulation results of different simulation tools under the same pre-cooling strategy. For "Two Parkside" and "Three Carnegie Plaza", the demand sheds that eQUEST and BEST predicted were lower than the actual data by as much as $40 \%$. The relative difference between the simulation results of DRQAT and the actual data was about 10 to $20 \%$. "Brier Corporate Center"'s eQUEST and BEST simulations under-predicted while DRQAT over-predicted the savings.

\section{Table 15: Simulation Results of Demand Shed for DR Strategy (KW)}

\begin{tabular}{|c|c|c|c|c|c|c|c|c|}
\hline \multirow{2}{*}{ TEST BUI LDI NG } & \multicolumn{2}{|c|}{ EQUEST } & \multicolumn{2}{|c|}{ BEST } & \multicolumn{2}{|c|}{ DRQAT } & \multicolumn{2}{|c|}{ ACtuAl Data } \\
\hline & MaX & Ave & MAX & Ave & MAX & Ave & MaX & Ave \\
\hline Two Parkside & 42.9 & 35.6 & 59.7 & 43.5 & 99.4 & 53.4 & 119.8 & 66.0 \\
\hline Three Carnegie Plaza & 39.3 & 32.7 & 42.1 & 29.2 & 80.7 & 49.0 & 74.5 & 55.1 \\
\hline Brier Corporate Center & 55.0 & 42.4 & 64.0 & 47.3 & 125.0 & 68.0 & 91.2 & 56.9 \\
\hline
\end{tabular}

\section{THERMALMASS LEVEL}

Both eQUEST and DRQAT provide the capability to adjust building thermal mass, while BEST does not. In eQUEST and BEST, the type and coverage of the furniture can be specified for better calculation of the actual building thermal mass. Therefore, the simulation results of two types of thermal mass level were compared in this report. Figure 19 shows the comparison of different thermal mass level for eQUEST and DRQAT. The results indicated that, with DRQAT, the level of thermal mass affected the simulated demand shed much more than it did with eQUEST. The average demand difference between the "High" and "Medium" was about $10 \mathrm{~kW}$. The demand was raised by as much as $20 \%$ when compared with the average demand shed of "Medium" in the thermal mass models. 


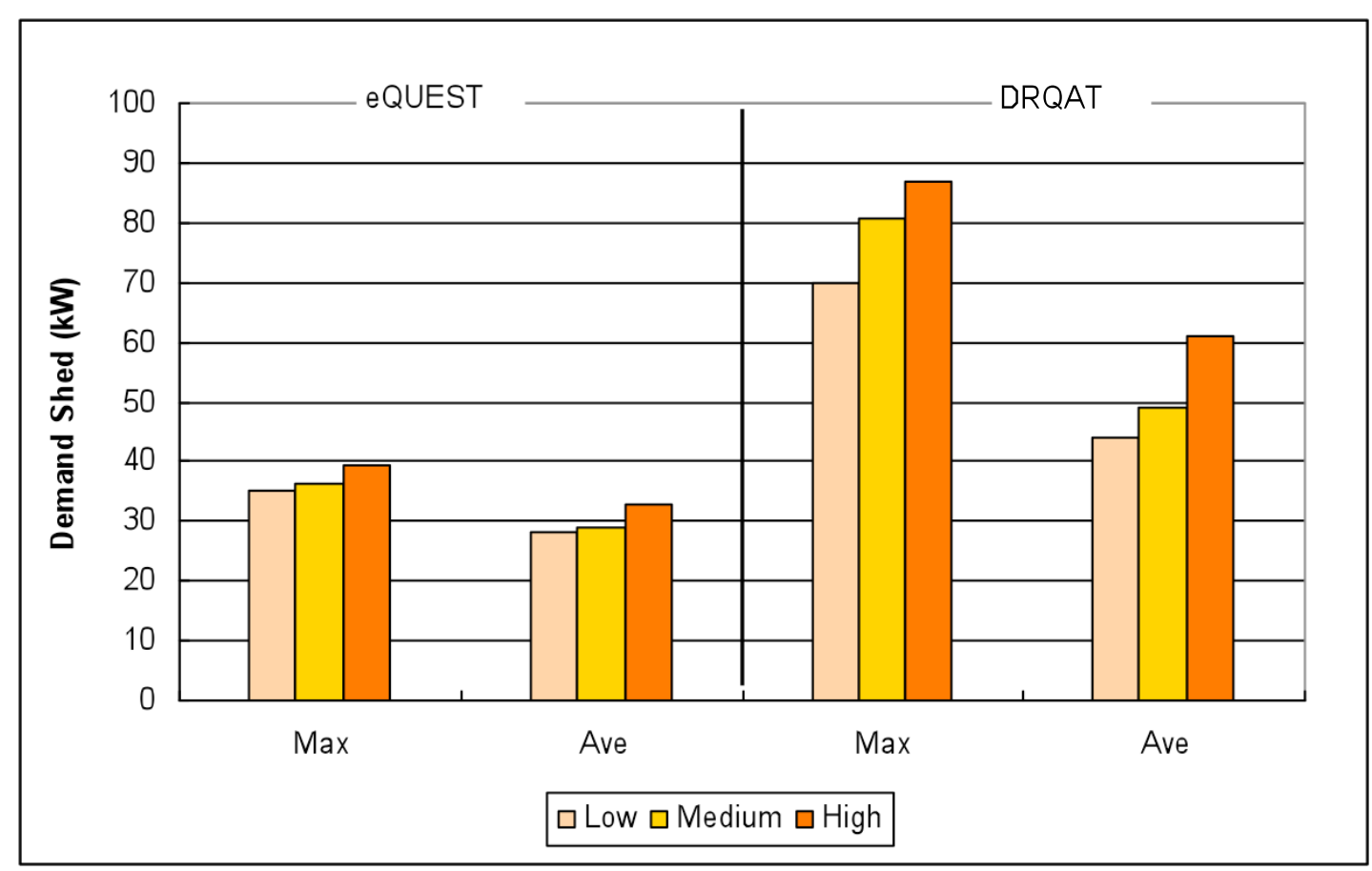

Figure 15: Simulation Results of Different Thermal Mass Level for eQUeSt and DRQAT

\section{SUMMARY}

With simple inputs, friendly interface, powerful calculation core, and flexibility in reporting outputs, DRQAT has many advantages against the two other tools in predicting DR sheds. Comparison of the simulation results to the field test data indicated that the simulation model developed by DRQAT could well match the actual energy usage of buildings in the Tri-City Corporate Center. Other building energy simulation tools such as EQUEST and BEST were able to simulate the effects of demand response strategies and generate some reasonable results as well.

However, when the simulation results were compared to the measured data, the predicted demand reductions by eQUEST and BEST were lower than that for the measured data. This is because DOE2 does not handle thermal mass in walls properly in the load adjusting module. DRQAT seems to be more accurate than the other two tools in estimating demand reductions due to demand response strategies. 


\section{CONCLUSIONS AND RECOMMENDATIONS}

\section{CONCLUSIONS}

This project studied how to optimize pre-cooling strategies for the buildings in the Tri-City Corporate Center, San Bernardino, California, with the assistance of Demand Response Quick Assessment Tool (DRQAT) - a building energy simulation tool.

Eleven DRQAT models were built for the buildings in the Tri-City Corporation Center. The simulation results from calibrated simulation models matched well with the measured monthly, daily and hourly data. Using the calibrated simulation models, a series of simulations were conducted to determine the optimal pre-cooling strategies for the eleven buildings. The "Pre-cooling with step temp set up" and "Pre-cooling with exponential temp set up" strategies turned out to be the optimal strategies. The "Pre-cooling with step temp set up" was used in the field tests as it was easier to implement and had a flatter load shape at the beginning of the peak demand period.

The resulting simulation-based DR optimization is summarized into a procedure to develop and calibrate DRQAT building models with the following steps:

- Generate a DRQAT initial simulation model with basic building information.

- Replace TMY weather file in DRQAT and regenerate a .epw EnergyPlus file with real weather data collected from the site or nearby weather stations.

- Use whole building power under extreme cold weather conditions to estimate the actual internal load schedules. The method will not work if electricity or heat pumps were used as heating sources.

- Run simulations and compare the simulated results with the measure data.

- Readjust the internal load schedule until the simulated daily and monthly demand data match with the measured data.

The field test results indicated that the pre-cooling strategies were able to reduce the peak demand as expected on CPP event days. The demand reductions for each building were different and pre-cooling strategies to each building should be matched based on demand reductions.

If a building owner decides not to sign up for the CPP program, but wants to use the pre-cooling strategies to reduce their monthly demand charge, the buildings should operate the pre-cooling strategies on days when the weather forecast predicts outside air temperature above $90^{\circ} \mathrm{F}$. From the thermal comfort point of view, it will be better to operate the pre-cooling strategies throughout summer periods because the occupants can predict the temperature variation in advance and dress accordingly.

The demand shed predicted by DRQAT matched well with the measured data on CPP event days. The study showed that after refining and calibrating the initial simulation models with measured data, the accuracy of the models are greatly improved and the models can be used to predict load reductions in these buildings on DR event days within $\pm 10 \%$ of accuracy. 
The simulation results of eQUEST, BEST, the two simulation tools built on different versions of DOE2, indicate that these tools did not work as well as the DRQAT in predicting demand reduction. The predicted demand sheds from these two tools seemed to be lower than the actual data. DRQAT can better simulate the DR effects because both eQUEST and BEST underestimate the effect of thermal mass of walls.

\section{RECOMMENDATIONS}

Although the carefully calibrated baseline model can match the measured interval meter data within the requirements of the ASHRAE Guide, we believe the efforts in the following areas can further improve the accuracy of the simulations and usefulness of the DRQAT tool.

- Real weather data. The real weather file that we use to calibrate the simulation model may be different than the actual weather data for the building. An outside air sensor or weather station should be installed in the building to measure the outside air temperature on site. This measured data can be converted into a weather file and used in the DRQAT simulation. This will greatly improve the accuracy of the model prediction.

- Sub-metered HVAC and whole building power. It was hard to estimate the internal loads without sub-metering. The winter data can be used to estimate the internal load schedules in summer. However, the internal load estimate could be improved by sub-metering key HVAC equipment. Direct measurement or short term spot measurements could provide strong evidence in backing up the models and predicting savings.

- Determine internal mass level. It is difficult to estimate the mass level in different buildings. The default value in DRQAT was inherited from EnergyPlus prototypical models and those values may not be representative of real buildings in California.

- Adding utility baselines to the DRQAT. Utilities use different baseline methodologies for their various DR programs. A simulated baseline day was used in the simulation analysis which, except for the zone temperature setpoints for the pre-cooling strategies, have the same operating conditions as the DR event day. In estimating the DR savings from the field, baselines with similar outdoor temperature profiles were used. However, in reality, no baseline day exists with same weather condition, internal loads and other electrical usage for an actual DR event day. Adding specific utility baselines to DRQAT will improve usability and predicting economic savings.

- Refining accuracy requirements for DR simulations. While the calibration met the requirement in the ASHRAE standard, within $\pm 20 \%$ for a minimum of 20 hours out of 24 hours for each day, this standard was established for energy simulations. DR reductions are usually within $10 \%$ to $15 \%$ of the peak load and may be within the error margin between the simulated and measured data. Accuracy requirements for DR simulations have to be developed. 


\section{REERENCES}

ASHRAE. 21002. ASHRAE Guideline 14-2002, Measurement of Energy and Demand Savings. Atlanta: American Society of Heating, Refrigerating and Air-Conditioning Engineers, Inc.

California's Energy Efficiency Standards for Residential and Nonresidential Buildings, 1987, 1988, 1992, 1995, 1998, 2001 and 2005.

Yiqun Pan, Zhizhong Huang, Gang Wu, Chen Chen. 2006. The Application of Building Energy Simulation and Calibration in Two High-rise Commercial Buildings in Shanghai, Proceedings of SimBuild 2006, August 2-4, 2006.

Yiqun Pan, Rongxin Yin, Zhizhong Huang. 2008. Energy modeling of two office buildings with data center for green building design, Energy and Buildings, October 2, 2008.

Peng Xu, Leah Zagreus, Demand Shifting With Thermal Mass in Light and Heavy Mass Commercial Buildings, LBNL 61172, July 2007.

Peng Xu, Philip Haves, MaryAnn Piette. 2005. Demand Shifting With Thermal Mass in Large Commercial Buildings: Field Tests, Simulations and Audits. LBNL 58815, December 2005.

Peng Xu, Rongxin Yin, etc. 2006. Demand Shifting With Thermal Mass in Large Commercial Buildings in California Hot Climate Zone. LBNL 61172.

M.A Piette, D. Watson, N.Motegi, S.Kiliccote. 2007. Automated Critical Peak Pricing Field Tests: 2006 Pilot Program Description and Results, LBNL 62218, August 30, 2007.

Joe Huang, Hashem Akbari, Leo Rainer, and Ron Ritschard. Lawrence Berkeley Laboratory, Applied Science Division. "481 Prototypical Commercial Buildings For 20 Urban Market Areas". Technical documentation of building loads data base developed for the GRI Cogeneration Market Assessment Model. April 1991.

A. Pedrini, F.S. Westphal, R. Lamberbs, A methogology for building energy modeling and calibration in warm climates, Building and Environment, 2002.

Katie Coughlin, Mary Ann Piette, Charles Goldman and Sila Kiliccote, Estimating Demand Response Load Impacts: Evaluation of Baseline Load Models for Non-Residential Buildings in California, LBNL 63728, January 2008.

M.A Piette, D. Watson, N. Motegi, S. Kiliccote, P. Xu, Automated Critical Peak Pricing Field Tests: Program Description and Results, LBNL 59531, April 2006.

Torcellini, P., M. Deru, et al. DOE Commercial Building Benchmark Models. Proceeding of 2008 ACEEE Summer Study on Energy Efficiency in Buildings, Pacific Grove, California. August 17-22, 2008. 


\section{APPENDIX A - BUILING AUDITS}

An audit template was developed to collect the input information for DRQAT. The audit information includes general building description, building internal load and HVAC system.

\section{Two CaRnegie Plaza}

\section{Table A 1: Building Audit-Two Carnegie Plaza}

\section{General I NFORMATI ON}

Building name

Total square footage

Numbers of floors

Location

Year constructed

Function

BUI LDI NG ENVELOPE

Construction Material

Windows

Window to wall ratio

\section{NTERnAL MASS}

Uncarpeted slab

Slab thickness (inch)

\section{NTERNAL LOAD}

Occupant

Lighting

Equipment

Schedule

Occupant schedule

HVAC operating schedule

\section{HVAC SYSTEM}

Air Distribution Type

Zone temperature set points

Cooling Plant

Air Handing Unit Fan Control
Two Carnegie Plaza

68,955

2

685 Carnegie Drive, San Bernardino, CA 92408

1990

Office $60 \sim 70 \%$

\section{Masonry}

Single-pane, low-e

$50 \%$ on all sides

$2 \%$

4

Unavailable, Regular office

Unavailable, Regular office

Unavailable, Regular office

Unavailable

$5 \mathrm{am}-6 \mathrm{pm}$

Variable air volume

77 (Cooling)

Packaged DX, 4 units, $2 * 50$ TOU, 2*55 TOU

Variable speed drive 


\section{One Carnegie Plaza}

\section{Table A 2: Bullding Audit-One Carnegie Plaza}

\section{General I NFORMATI ON}

Building name

Total square footage

Numbers of floors

Location

Year constructed

Function

\section{BuI LDI NG ENVELOPE}

Construction Material

Windows

Window to wall ratio

\section{NTERNAL MASS}

Uncarpeted slab

Slab thickness (inch)

\section{NTERNAL LOAD}

Occupant

Lighting

Equipment

\section{SCHEdULe}

Occupant schedule

HVAC operating schedule

\section{HVAC SYSTEM}

Air Distribution Type

Zone temperature set points

Cooling Plant

Air Handing Unit Fan Control
One Carnegie Plaza

62,800

2

625 Carnegie Drive, San Bernardino, CA 92408

1988

Office $100 \%$

Masonry

Single-pane, low-e

$50 \%$ on all sides

$2 \%$

4

Unavailable, Regular office

Unavailable, Regular office

Unavailable, Regular office

Unavailable

$5 \mathrm{am}-6 \mathrm{pm}$

Variable air volume

77 (Cooling)

Packaged DX, 4 units, $2 * 50$ TOU, 2*55 TOU

Variable speed drive 


\section{One CARNegie Plaza (smaUer bUIDING)}

\section{Table A 3: Building Audit-One Carnegie Plaza (smaller building)}

\section{GeNERAL I NFORMATI ON}

Building name

Total square footage

Numbers of floors

Location

Year constructed

Function

BUI LDI NG ENVELOPE

Construction Material

Windows

Window to wall ratio

\section{NTERnAL MASS}

Uncarpeted slab

Slab thickness (inch)

\section{NTERNAL LOAD}

Occupant

Lighting

Equipment

\section{SCHEDULE}

Occupant schedule

HVAC operating schedule

\section{HVAC SYSTEM}

Air Distribution Type

Zone temperature set points

Cooling Plant

Air Handing Unit Fan Control
One Carnegie Plaza (smaller building)

38,808

2

621 Carnegie Drive, San Bernardino, CA 92408

1988

Office $100 \%$

Masonry

Single-pane, low-e

$50 \%$ on all sides

\section{$2 \%$}

4

Unavailable, Regular office

Unavailable, Regular office

Unavailable, Regular office

Unavailable

5 am - 6 pm

Variable air volume

77 (Cooling)

Packaged DX, 2 units, $1 * 50$ TOU, $1 * 60$ TOU

Variable speed drive 


\section{One VANDerbilt}

\section{Table A 4: Building Audit-One Vanderbilt}

\section{General I NFORMATI ON}

Building name

One Vanderbilt

Total square footage

73,730

Numbers of floors

3

Location

301 E. Vanderbilt Way, San Bernardino, CA 92408

Year constructed 1988

Function

Office $55 \%$, bank $50 \%$

BUILDing EnVELOPE

Construction Material

Curtain wall

Windows

Single-pane, low-e

Window to wall ratio

$25 \%$ on all sides

I NTERNAL MASS

Uncarpeted slab

$2 \%$

Slab thickness (inch)

4

\section{NTERNAL LOAD}

Occupant

Lighting

Equipment

\section{SCHEDULe}

Occupant schedule

HVAC operating schedule

\section{HVAC SYSTEM}

Air Distribution Type

Zone temperature set points

Cooling Plant

Air Handing Unit Fan Control
Unavailable, Regular office

Unavailable, Regular office

Unavailable, Regular office

Unavailable

5 am - 6 pm

Variable air volume

77 (Cooling)

Packaged DX, 4 units, 3*55 TOU, 1*60 TOU

Variable speed drive 


\section{ONE PARKSIDE}

\section{Table A 5: Bullding Audit-One Parkside}

\section{General I NFORMATI ON}

Building name

One Parkside

Total square footage

70,069

Numbers of floors

4

Location

560 E. Hospitality Lane, San Bernardino, CA 92408

Year constructed

\section{3}

Function

Office $100 \%$

BUI LDI NG ENVELOPE

Construction Material

Curtain wall

Windows

Single-pane, low-e

Window to wall ratio

$60 \%$ on all sides

I NTERNAL MASS

Uncarpeted slab

$2 \%$

Slab thickness (inch)

4

\section{NTERNAL LOAD}

Occupant

Lighting

Equipment

\section{SCHEDULe}

Occupant schedule

HVAC operating schedule

\section{HVAC SYSTEM}

Air Distribution Type

Zone temperature set points

Cooling Plant

Air Handing Unit Fan Control
Unavailable, Regular office

Unavailable, Regular office

Unavailable, Regular office

Unavailable

5 am - 6 pm

Variable air volume

77 (Cooling)

Packaged DX, 4 units, 4*55 TOU

Variable speed drive 


\section{LAKESIDE TOWER}

\section{Table A 6: Building Audit-Lakeside Tower}

\section{General I nFormati on}

Building name

Total square footage

Numbers of floors

Location

Year constructed

Function

Building Envelope

Construction Material

Windows

Window to wall ratio

I NTERnAL MASS

Uncarpeted slab

Slab thickness (inch)

I NTERNAL LoAD

Occupant

Lighting

Equipment

\section{Schedule}

Occupant schedule

HVAC operating schedule

\section{HVAC SYSTEM}

Air Distribution Type

Zone temperature set points

Cooling Plant

Air Handing Unit Fan Control
Lakeside Tower

112,717

6

650 E. Hospitality Lane, San Bernardino, CA 92408

1990

Office $100 \%$

Frame

Single-pane, low-e

$60 \%$ on all sides

\section{$2 \%$}

4

Unavailable, Regular office

Unavailable, Regular office

Unavailable, Regular office

Unavailable

$5 \mathrm{am}-6 \mathrm{pm}$

Variable air volume

77 (Cooling)

Central chiller, $2 * 175$ reciprocating chiller

Variable speed drive 


\section{TWO PARKSIDE}

\section{Table A 7: Bullding Audit-Two Parkside}

\section{General I nFormati on}

Building name

Two Parkside

Total square footage

80,750

Numbers of floors

3

Location

550 E. Hospitality Lane, San Bernardino, CA 92408

Year constructed 2001

Function

Office $90 \%$, classroom $10 \%$

Bui LDI NG EnVelope

Construction Material

Frame

Windows

Single-pane, low-e

Window to wall ratio

$40 \%$ on all sides

I NTERNAL MASS

Uncarpeted slab

$2 \%$

Slab thickness (inch)

4

\section{NTERNAL LOAD}

Occupant

Lighting

Equipment

\section{SCHEDULE}

Occupant schedule

HVAC operating schedule

\section{HVAC SYSTEM}

Air Distribution Type

Zone temperature set points

Cooling Plant

Air Handing Unit Fan Control
Unavailable, Regular office

Unavailable, Regular office

Unavailable, Regular office

Unavailable

5 am - 6 pm

Variable air volume

77 (Cooling)

Packaged DX, 2 units, 2*90 TOU

Variable speed drive 


\section{THREe Carnegie Plaza}

\section{Table A 8: Bullding Audit-Three Carnegie Plaza}

\section{General I nFormati on}

Building name

Three Carnegie Plaza

Total square footage

83,698

Numbers of floors

2

Location

735 Carnegie Drive, San Bernardino, CA 92408

Year constructed

2003

Function

Office $100 \%$

BUILDING ENVELOPE

Construction Material

masonry

Windows

Single-pane, low-e

Window to wall ratio

$40 \%$ on all sides

I NTERNAL MASS

Uncarpeted slab

$25 \%$

Slab thickness (inch)

4

\section{NTERNAL LOAD}

Occupant

Lighting

Equipment

\section{Schedule}

Occupant schedule

HVAC operating schedule

\section{HVAC SYSTEM}

Air Distribution Type

Zone temperature set points

Cooling Plant

Air Handing Unit Fan Control
Unavailable, Regular office

Unavailable, Regular office

Unavailable, Regular office

Unavailable

5 am - 6 pm

Variable air volume

77 (Cooling)

Packaged DX, 2 units, 2*50 TOU

Variable speed drive 


\section{Brier Corporate Center}

\section{Table A 9: Building Audit-Brier Corporate Center}

\section{General I nFormati ON}

Building name

Brier Corporate Center

Total square footage

104,501

Numbers of floors

3

Location

Year constructed

862 E. Hospitality Lane, San Bernardino, CA 92408

Function

2005

Office, conference rooms, data center

BUILDING ENVELOPE

Construction Material

Frame

Windows

Single-pane, low-e

Window to wall ratio

$40 \%$ on all sides

I NTERnal MASS

Uncarpeted slab

$50 \%$

Slab thickness (inch)

4

\section{NTERNAL LOAD}

Occupant

Unavailable, Regular office

Lighting

Unavailable, Regular office

Equipment

Unavailable, Regular office

\section{Schedule}

Occupant schedule

Unavailable

HVAC operating schedule

5 am - 6 pm

\section{HVAC SYSTEM}

Air Distribution Type

Variable air volume

Zone temperature set points

Cooling Plant

77 (Cooling)

Air Handing Unit Fan Control

Variable speed drive 


\section{VANDERBILTPLAZA}

\section{Table A 10: Bullding Audit-Vanderbilt Plaza}

\section{General I NFormati ON}

Building name

Vanderbilt Plaza

Total square footage

119,305

Numbers of floors

4

Location

Year constructed

451 E. Vanderbilt Way, San Bernardino, CA 92408

Function

2002

Office $75 \%$, classroom $25 \%$

BUILDing EnVELOPE

Construction Material

Frame

Windows

Single-pane, low-e

Window to wall ratio

$40 \%$ on all sides

I NTERNAL MASS

Uncarpeted slab

$20 \%$

Slab thickness (inch)

4

\section{NTERNAL LOAD}

Occupant

Lighting

Equipment

\section{SCHEDULe}

Occupant schedule

HVAC operating schedule

\section{HVAC SYSTEM}

Air Distribution Type

Zone temperature set points

Cooling Plant

Air Handing Unit Fan Control
Unavailable, Regular office

Unavailable, Regular office

Unavailable, Regular office

Unavailable

5 am - 6 pm

Variable air volume

77 (Cooling)

Packaged DX, 4 units, 2*50 TOU, 2*55 TOU

Variable speed drive 


\section{INLAND REGIONALC ENIER}

\section{Table A 11: Building Audit-Inland Regional Center}

\section{General I NFORMATI ON}

Building name

Inland Regional Center

Total square footage

81,079

Numbers of floors

2

Location

674 E. Brier Drive, San Bernardino, CA 92408

Year constructed 1994

Function

Office $75 \%$, auditorium $25 \%$

BUI LDI NG ENVELOPE

Construction Material

Masonry

Windows

Single-pane, low-e

Window to wall ratio

$30 \%$ on all sides

I NTERNAL MASS

Uncarpeted slab

$2 \%$

Slab thickness (inch)

4

\section{NTERNAL LOAD}

Occupant

Lighting

Equipment

\section{SCHEDULE}

Occupant schedule

HVAC operating schedule

\section{HVAC SYSTEM}

Air Distribution Type

Zone temperature set points

Cooling Plant

Air Handing Unit Fan Control
Unavailable, Regular office

Unavailable, Regular office

Unavailable, Regular office

Unavailable

5 am - 6 pm

Variable air volume

77 (Cooling)

Packaged DX, 4 units, 2*105 TOU, 2*90 TOU

Variable speed drive 


\section{APPENDIX B - BUIDING INTERNAL LOADS AND SCHEDULS}

\section{Table B 1: Building Internal Loads - Calibrated Baseline Model}

\begin{tabular}{|l|r|r|r|r|}
\hline \multicolumn{7}{c|}{ BuI LDI NG I NTERNAL LoAd } \\
\hline SI TE NAME & $\begin{array}{r}\text { YeAR } \\
\text { Constructed }\end{array}$ & $\begin{array}{r}\text { LIGHTI NG } \\
\text { DENSI TY } \\
\text { (W/ SQ FT) }\end{array}$ & $\begin{array}{r}\text { PLUG DeNSITY } \\
\text { ( W/ SQ FT) }\end{array}$ & $\begin{array}{r}\text { OCCUPANCY } \\
\text { ( SQ FT/ PER } \\
\text { PERSON) }\end{array}$ \\
\hline Two Carnegie Plaza & 1990 & 1.60 & $\mathbf{0 . 7 5}$ & 390 \\
\hline One Carnegie Plaza & 1988 & 1.60 & $\mathbf{1 . 5 0}$ & 390 \\
\hline One Carnegie Plaza & 1988 & 1.60 & $\mathbf{1 . 5 0}$ & 390 \\
\hline One Vanderbilt & 1988 & 1.60 & $\mathbf{1 . 8 0}$ & 390 \\
\hline One Parkside & 1993 & 1.60 & $\mathbf{1 . 4 0}$ & 390 \\
\hline Lakeside Tower & 1990 & 1.60 & $\mathbf{0 . 9 0}$ & 390 \\
\hline Two Parkside & 2001 & 1.20 & $\mathbf{1 . 5 0}$ & 390 \\
\hline Three Carnegie Plaza & 2003 & 1.20 & $\mathbf{0 . 6 0}$ & 390 \\
\hline Brier Corporate Center & 2005 & 1.10 & $\mathbf{1 . 4 0}$ & 390 \\
\hline Vanderbilt Plaza & 2002 & 1.20 & $\mathbf{1 . 0 0}$ & 390 \\
\hline Inland Regional Center & 1994 & 1.60 & $\mathbf{1 . 0 0}$ & 390 \\
\hline
\end{tabular}




\section{LGHIING AND PLUG SCHEDULES}

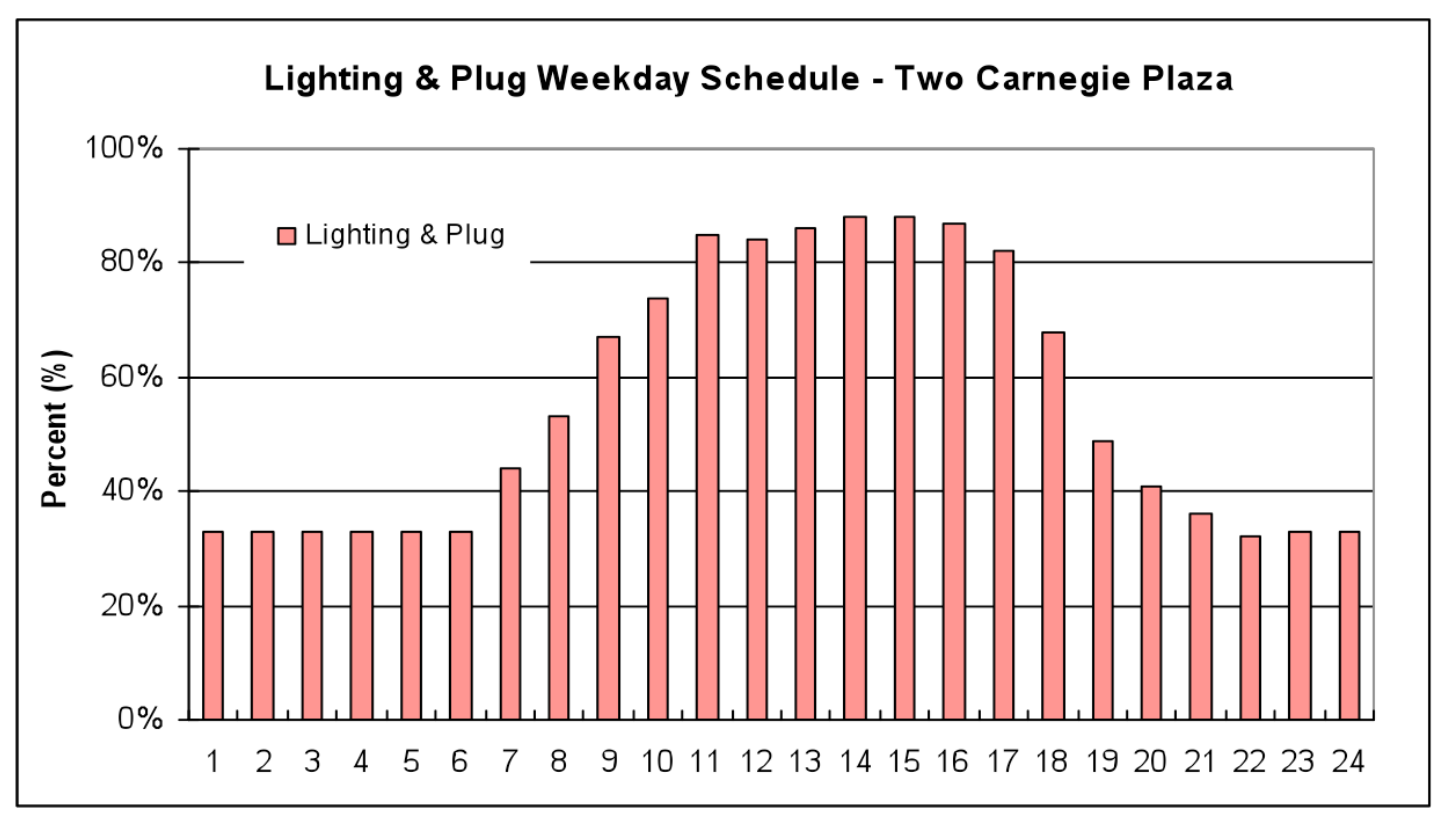

Figure B 1: Lighting and Plug Schedules - Two Carnegie Plaza

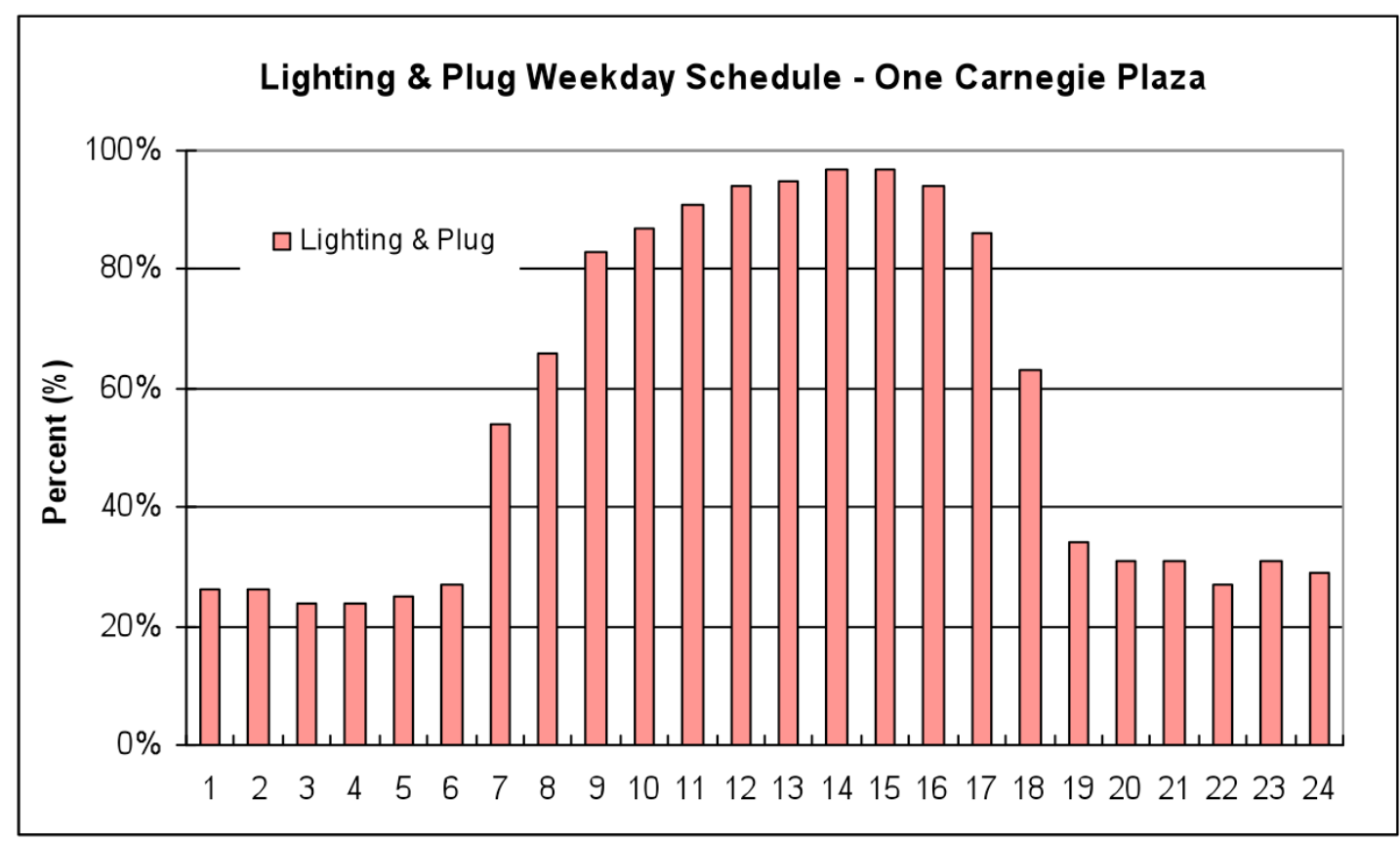

Figure B 2: Lighting and Plug Schedules - One Carnegie Plaza 


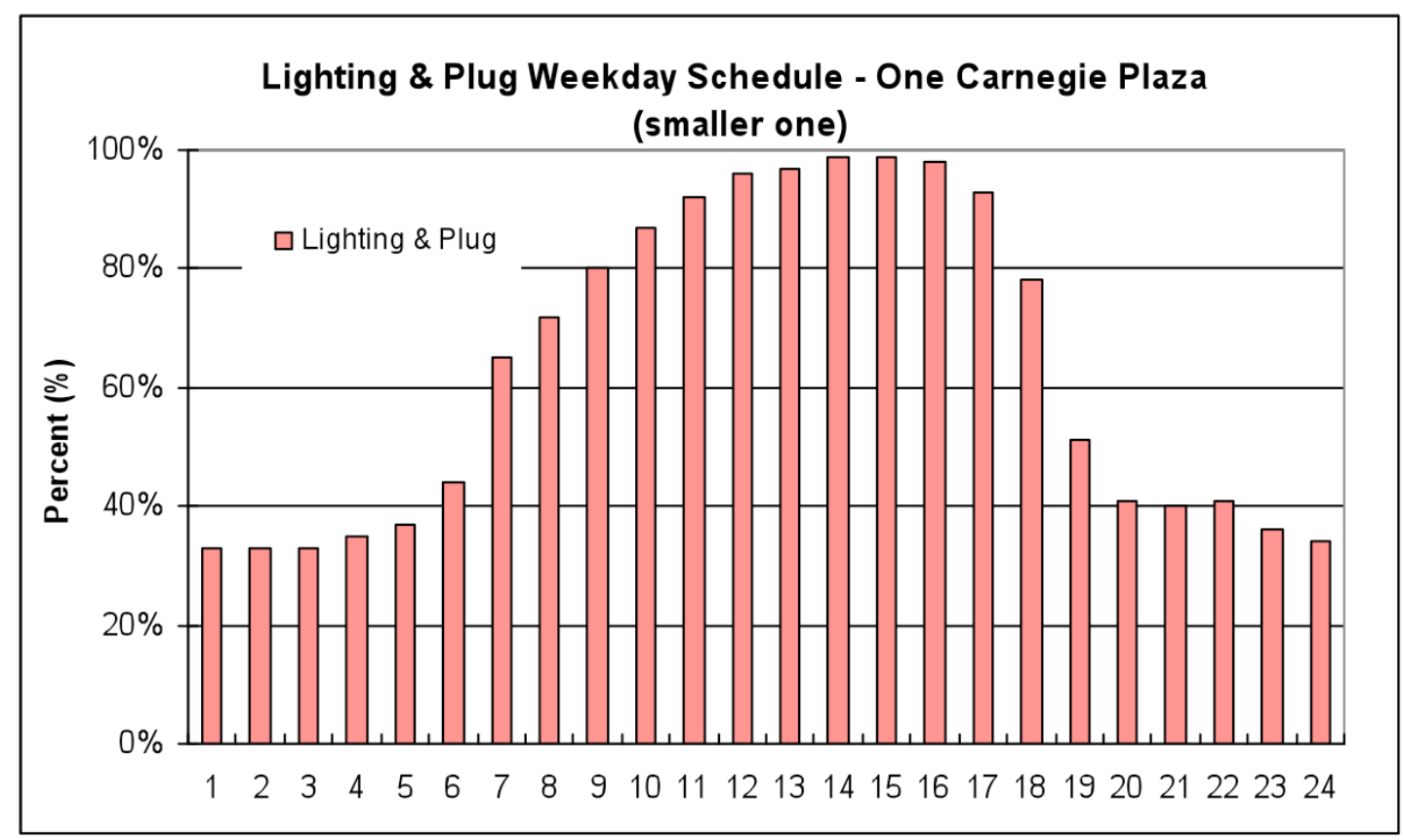

Figure B 3: Lighting and Plug Schedules - One Carnegie Plaza (smaller building)

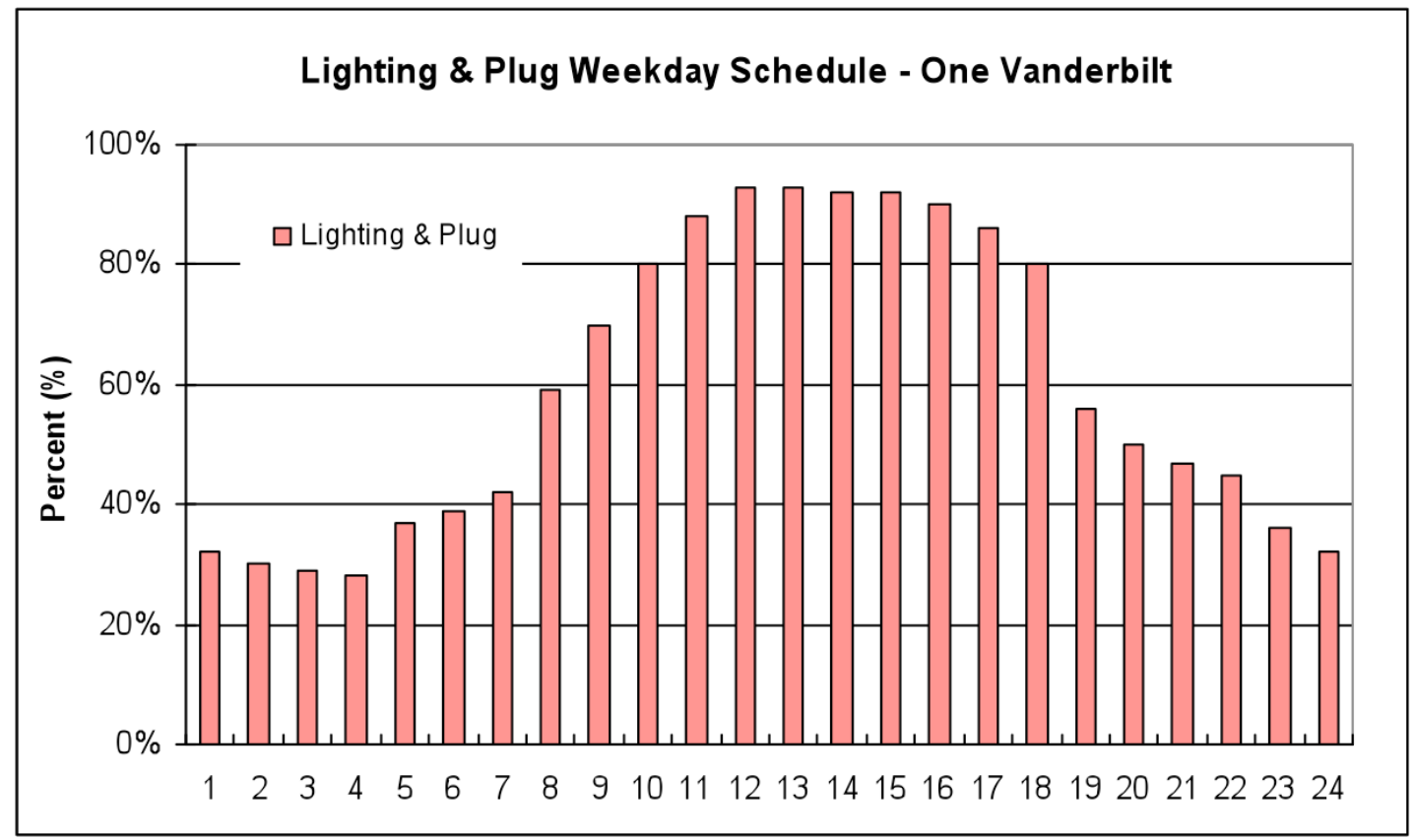

Figure B 4: Lighting and Plug Schedules - One Vanderbilt 


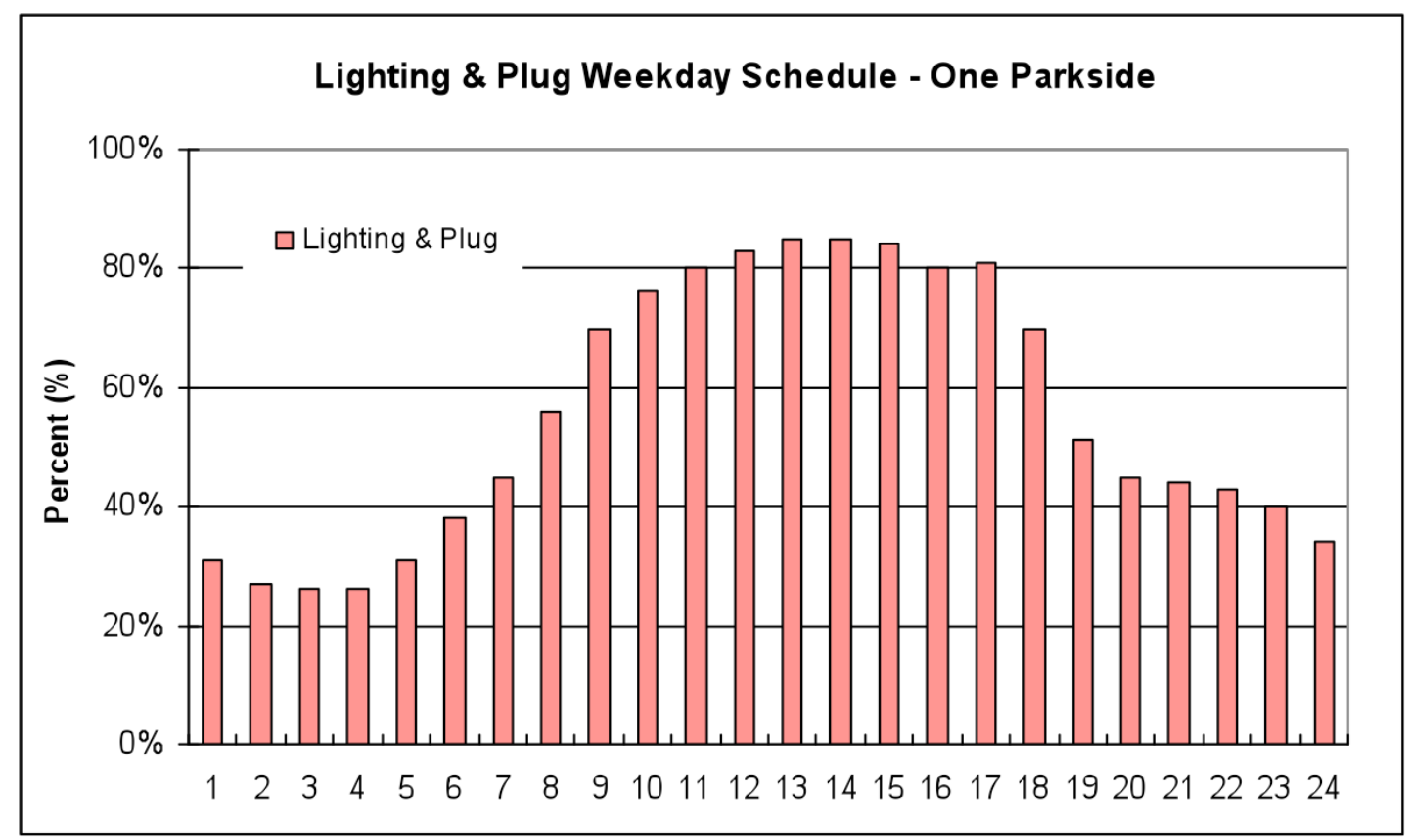

Figure B 5: Lighting and Plug Schedules - One Parkside

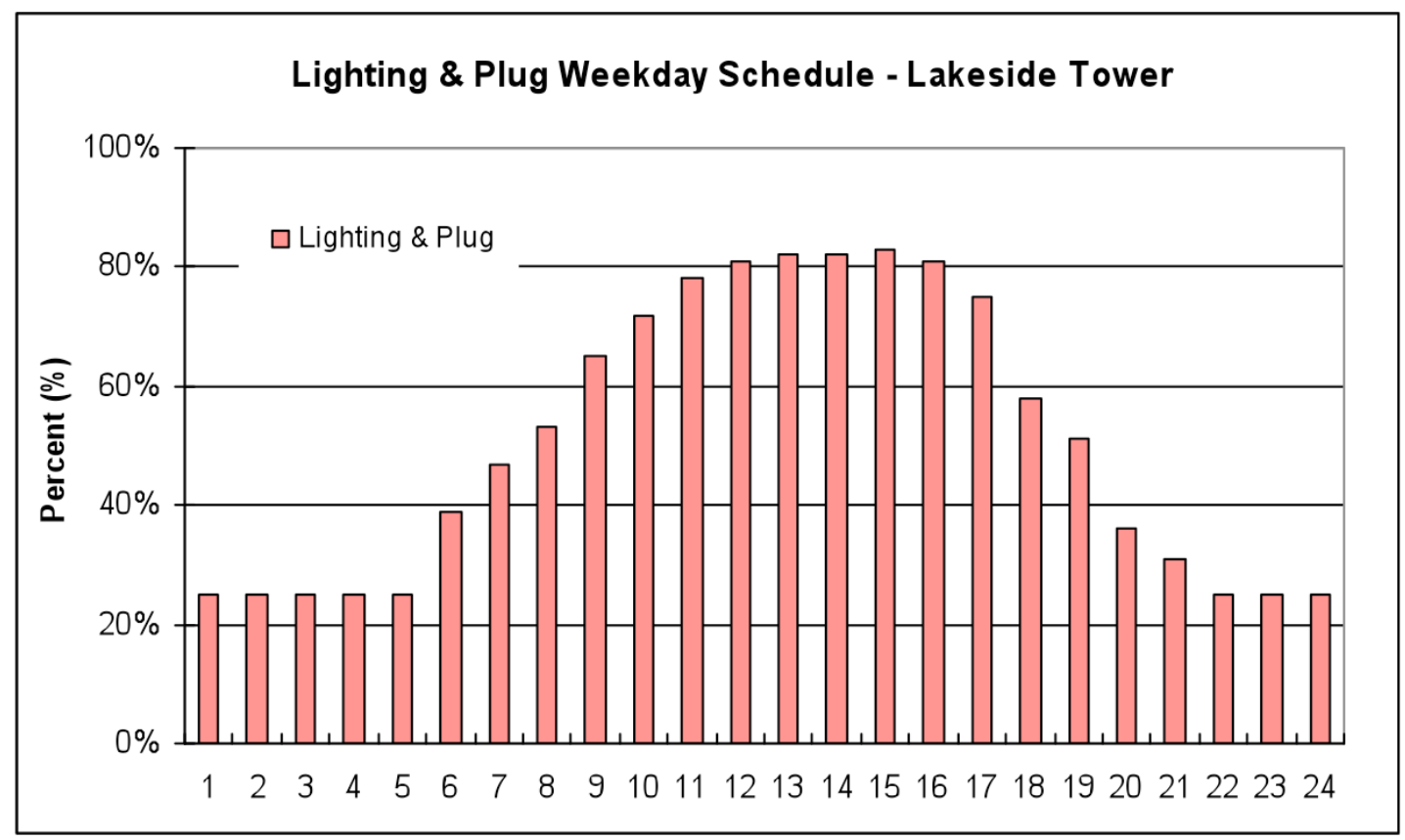

Figure B 6: Lighting and Plug Schedules - Lakeside Tower 


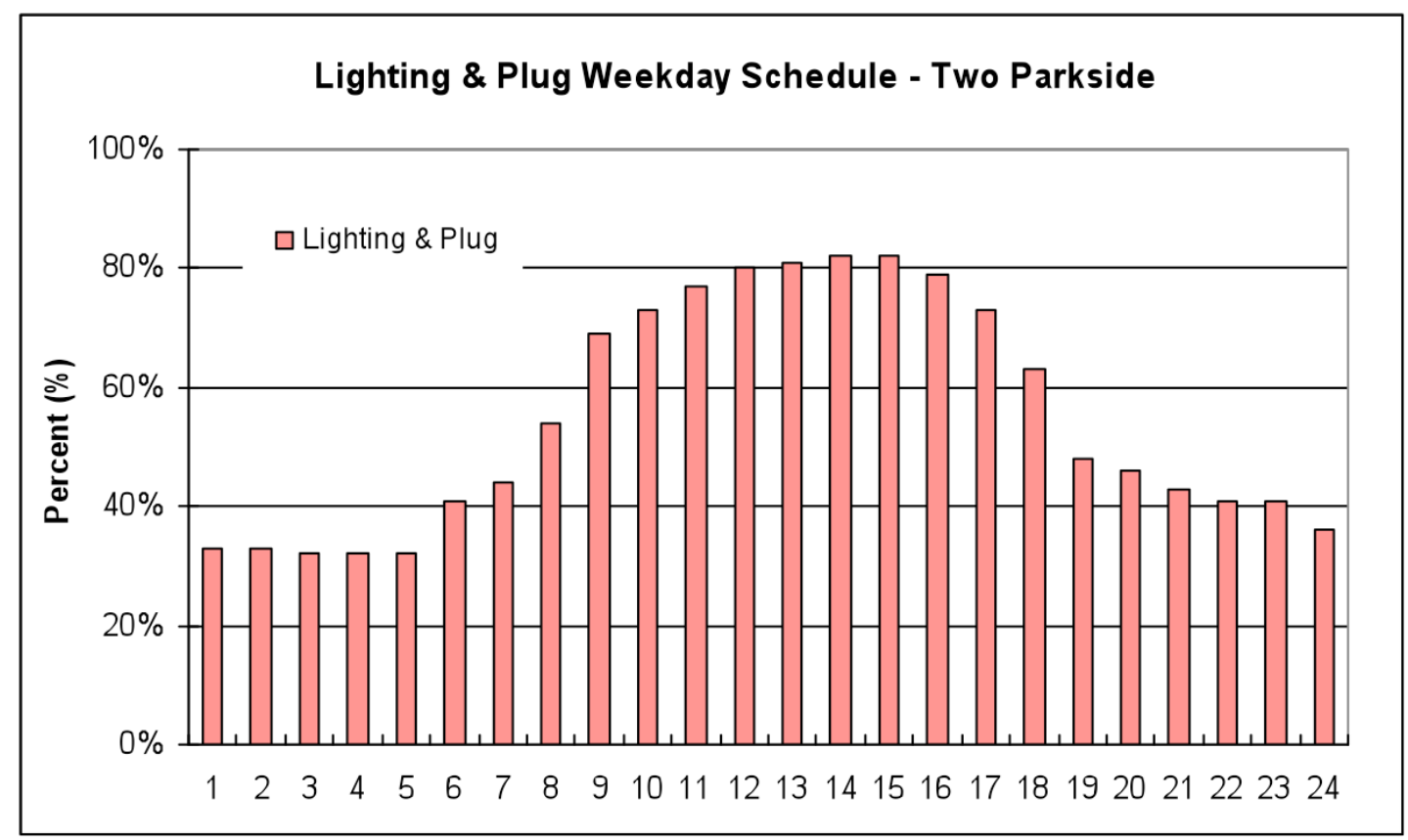

\section{Figure B 7: Lighting and Plug Schedules - Two Parkside}

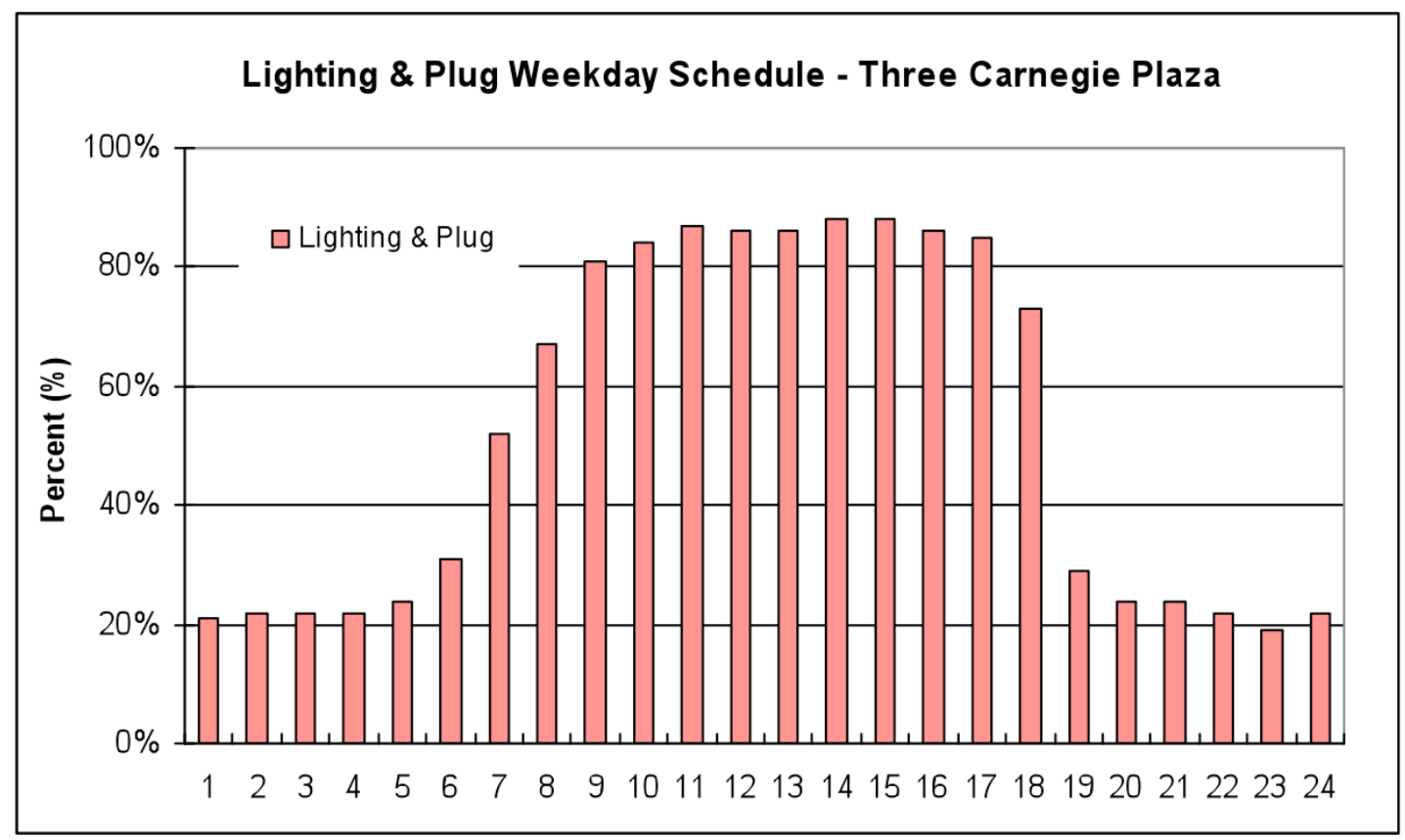

Figure B 8: Lighting and Plug Schedules - Three Carnegie Plaza 


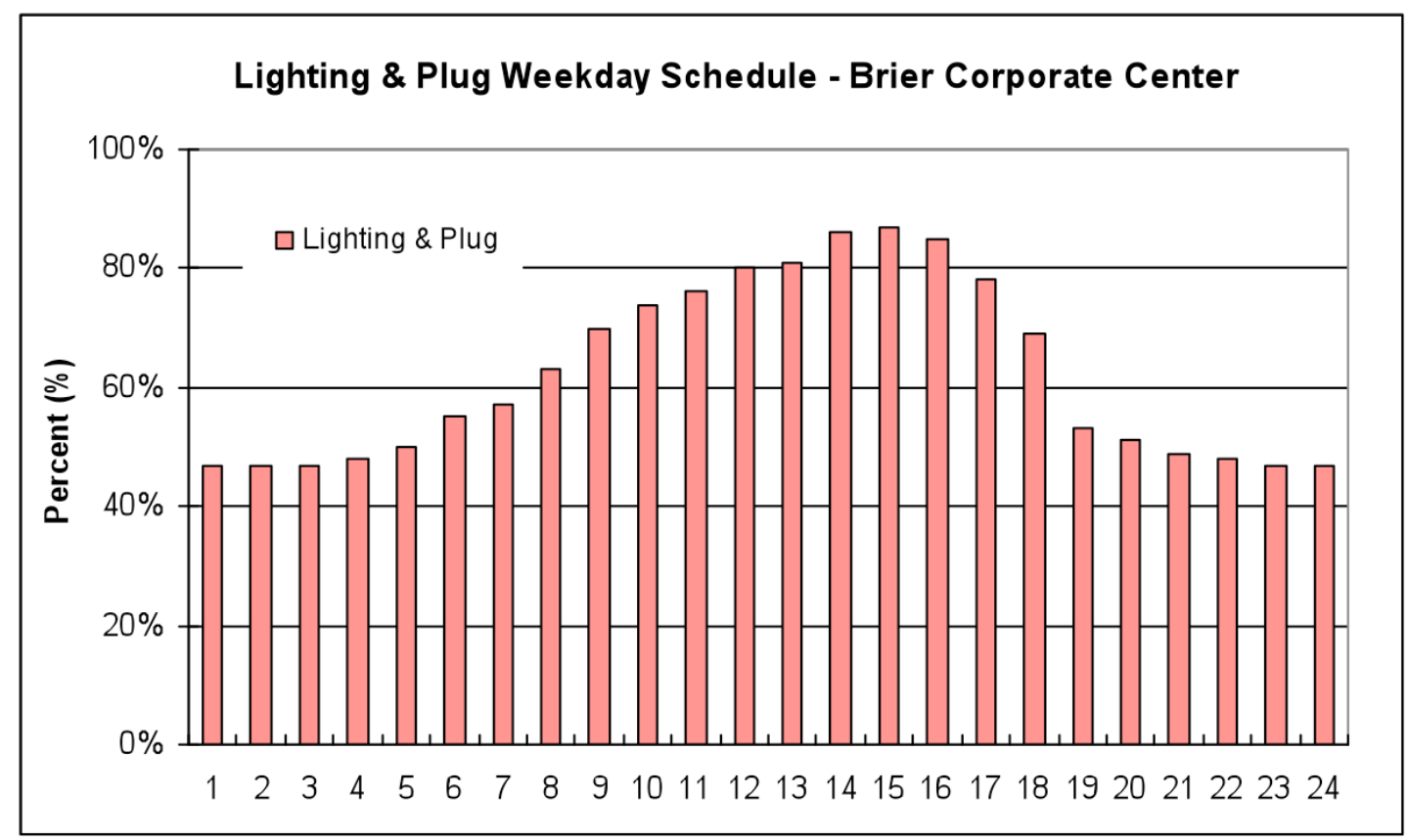

Figure B 9: Lighting and Plug Schedules - Brier Corporate Center

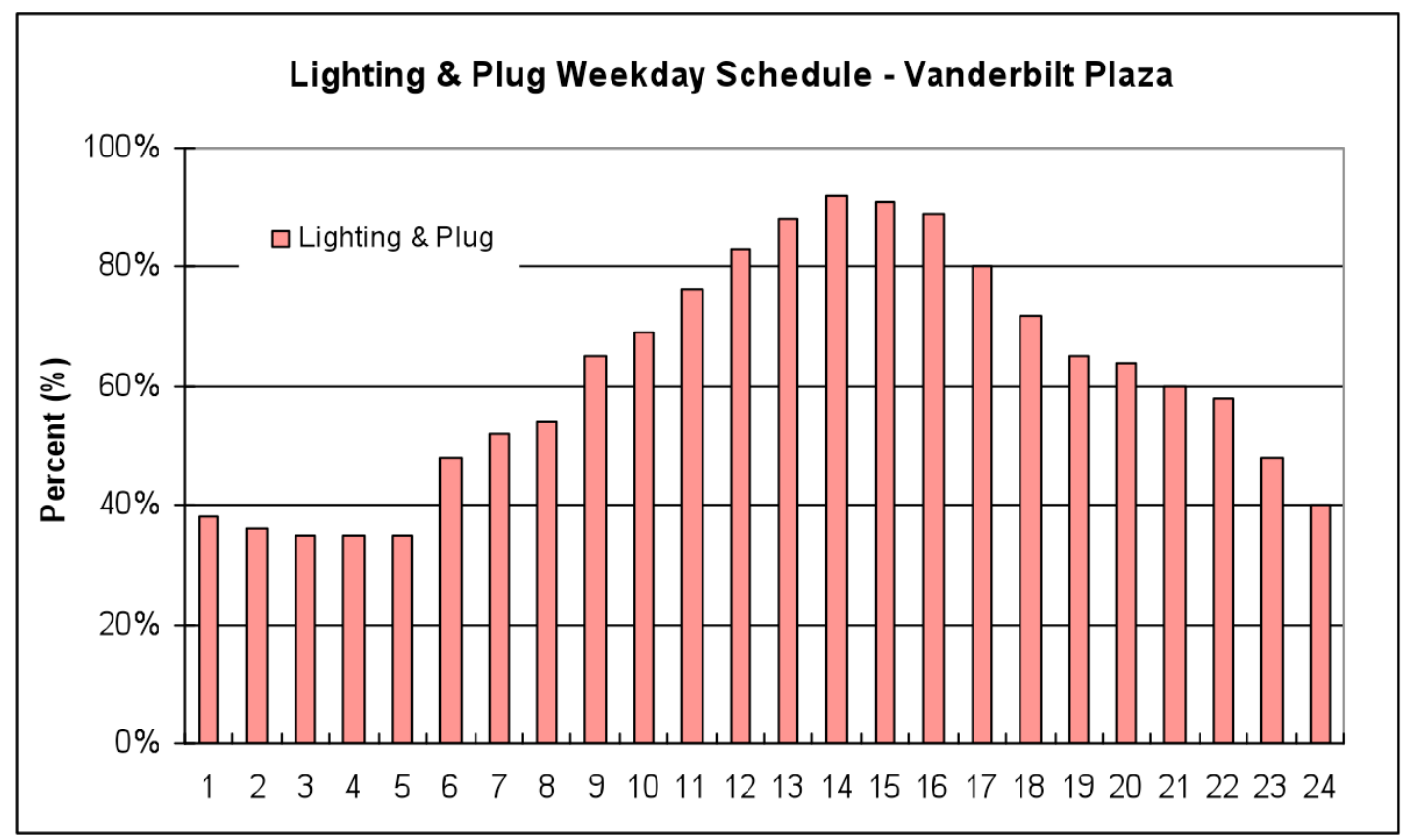

Figure B 10: Lighting and Plug Schedules - Vanderbilt Plaza 


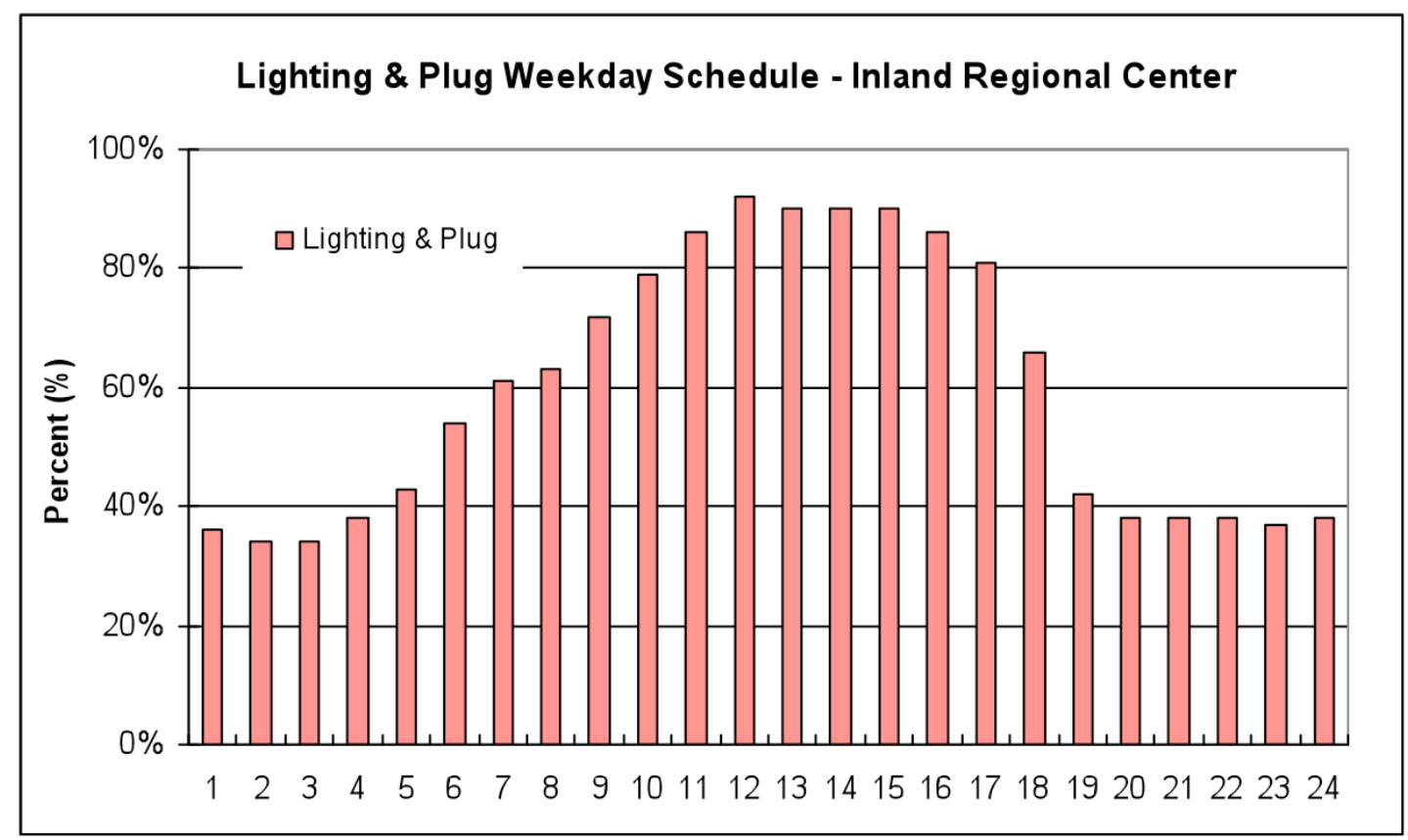

Figure B 11: Lighting and Plug Schedules - Inland Regional Center 


\section{ApPendix C - CaLbration Results}

\section{MONTHLY CALBRATION RESULTS}

\section{Table C 1: Comparison between Calibrated Simulation Results and Actual Data in} SUMMER 2007

\section{Site Name}

Two Carnegie Plaza

One Carnegie Plaza

One Carnegie Plaza

One Vanderbilt

One Parkside

Lakeside Tower

Two Parkside

Three Carnegie Plaza

\section{NDEX}

Measured

Simulation

Difference

Measured

Simulation

Difference

Measured

Simulation

Difference

Measured

Simulation

Difference

Measured

Simulation

Difference

Measured

Simulation

Difference

Measured

Simulation

Difference

Measured

Simulation

Difference

\section{MONTH (KWH)}

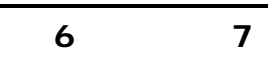

80,257

80,981

724

$1 \%$

86,551

91,053

4,502

$5 \%$

61,972

65,157

3,185

$5 \%$

146,649

148,845

$$
2,196
$$

$1 \%$

100,114

104,489

$$
4,375
$$

$4 \%$

141,811

149,166

$$
7,354
$$

$5 \%$

103,487

103,362

$-125$

0\%

67,019

69,931

2,912

7

90,791

95,495

4,704

$5 \%$

108,140

105,713

$-2,427$

$-2 \%$

75,944

75,965

21

$0 \%$

165,824

169,345

3,520

2\%

115,745

122,594

6,849

$6 \%$

168,731

170,884

2,153

$1 \%$

117,825

120,951

3,126

$3 \%$

80,051

84,550

4,499

\section{8}

94,380

95,472

1,092

$1 \%$

110,590

105,737

$-4,853$

$-4 \%$

82,813

75,447

$-7,366$

$-9 \%$

178,890

168,898

$-9,993$

$-6 \%$

121,942

123,318

1,376

$1 \%$

179,926

174,826

$-5,100$

$-3 \%$

124,713

122,953

$-1,760$

$-1 \%$

86,552

84,571

$-1,981$
Average

( $K W H)$

337,746

344,566

6,820

$2 \%$

392,084

384,753

$-7,331$

$-2 \%$

281,682

275, 009

$-6,674$

$-2 \%$

631,705

622,752

$-8,954$

$-1 \%$

432,751

446, 493

13,742

$3 \%$

630,606

635,906

5,301

$1 \%$

444,840

442,242

$-2,598$

$-1 \%$

301,350

300,356

$-994$ 
DR 06.22

\begin{tabular}{|c|c|c|c|c|c|c|}
\hline & & $4 \%$ & $6 \%$ & $-2 \%$ & $-9 \%$ & $0 \%$ \\
\hline \multirow{4}{*}{$\begin{array}{l}\text { Brier Corporate } \\
\text { Center }\end{array}$} & Measured & 159,325 & 178,754 & 187,255 & 164,857 & 690,191 \\
\hline & Simulation & 161,828 & 186,986 & 187,524 & 148,086 & 684,424 \\
\hline & \multirow[t]{2}{*}{ Difference } & 2,503 & 8,232 & 269 & $-16,771$ & $-5,767$ \\
\hline & & $2 \%$ & $5 \%$ & $0 \%$ & $-10 \%$ & $-1 \%$ \\
\hline \multirow{4}{*}{$\begin{array}{l}\text { Vanderbilt } \\
\text { Plaza }\end{array}$} & Measured & 127,048 & 152,719 & 165,028 & 125,764 & 570,559 \\
\hline & Simulation & 136,118 & 159,638 & 161,984 & 124,334 & 582,074 \\
\hline & \multirow[t]{2}{*}{ Difference } & 9,070 & 6,919 & $-3,044$ & $-1,430$ & 11,515 \\
\hline & & $7 \%$ & $5 \%$ & $-2 \%$ & $-1 \%$ & $2 \%$ \\
\hline \multirow{4}{*}{$\begin{array}{l}\text { Inland Regional } \\
\text { Center }\end{array}$} & Measured & 95,139 & 109,179 & 115,479 & 89,562 & 409,359 \\
\hline & Simulation & 99,944 & 115,992 & 116,928 & 90,549 & 423,413 \\
\hline & \multirow[t]{2}{*}{ Difference } & 4,805 & 6,813 & 1,449 & 987 & 14,054 \\
\hline & & $5 \%$ & $6 \%$ & $1 \%$ & $1 \%$ & $3 \%$ \\
\hline
\end{tabular}




\section{Wefkly and DaIly CAUBRATION RESUltS Two Carneg IE PLAZA}

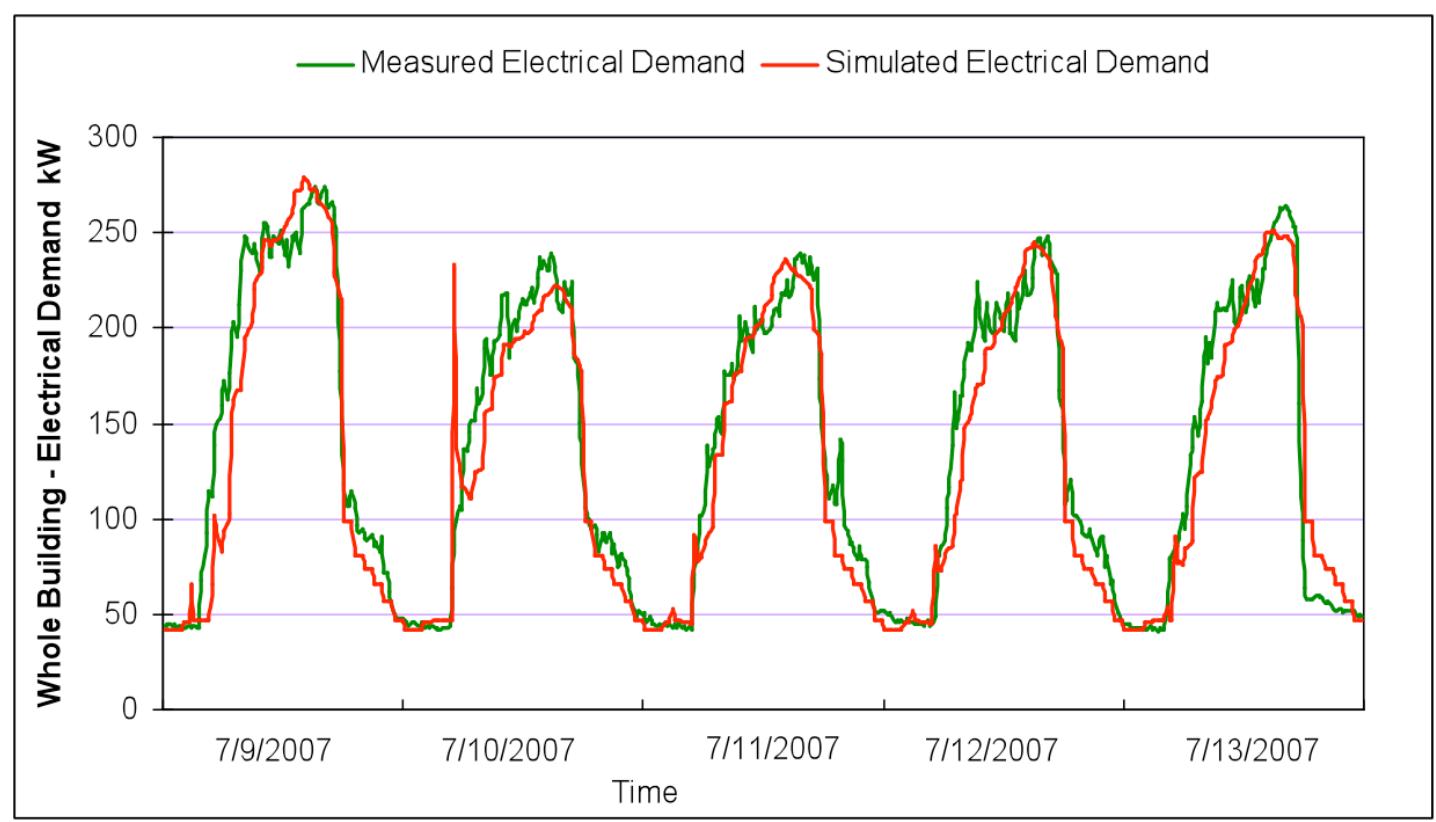

Figure C 1: Daily Electrical Consumption of Simulation Model vs. Actual Electrical Consumption in July - TWo Garnegie Plaza

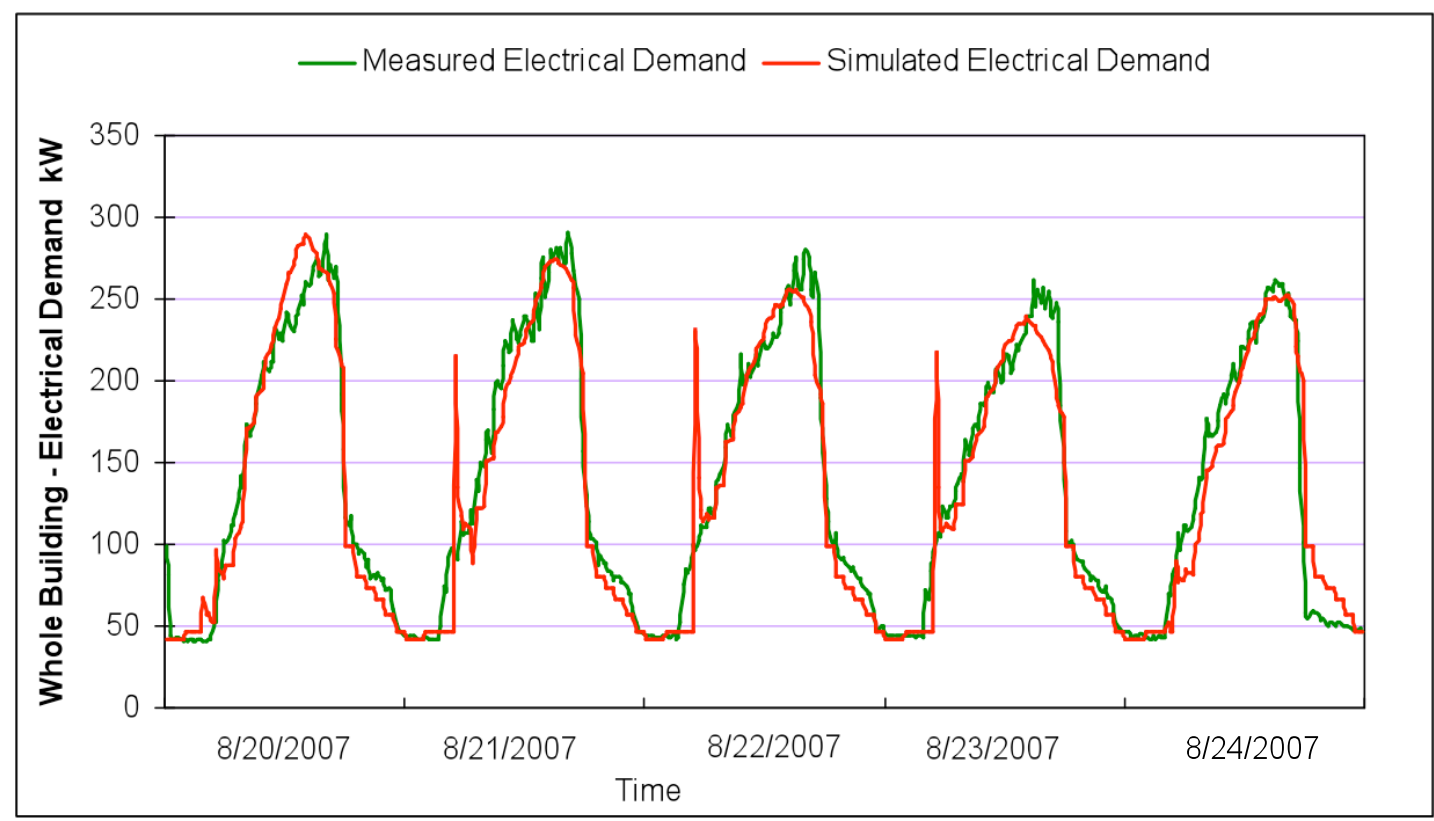

Figure C 2: Daily Electrical Consumption of Simulation Model vs. Actual Electrical Consumption in August - Two Carnegie Plaza 


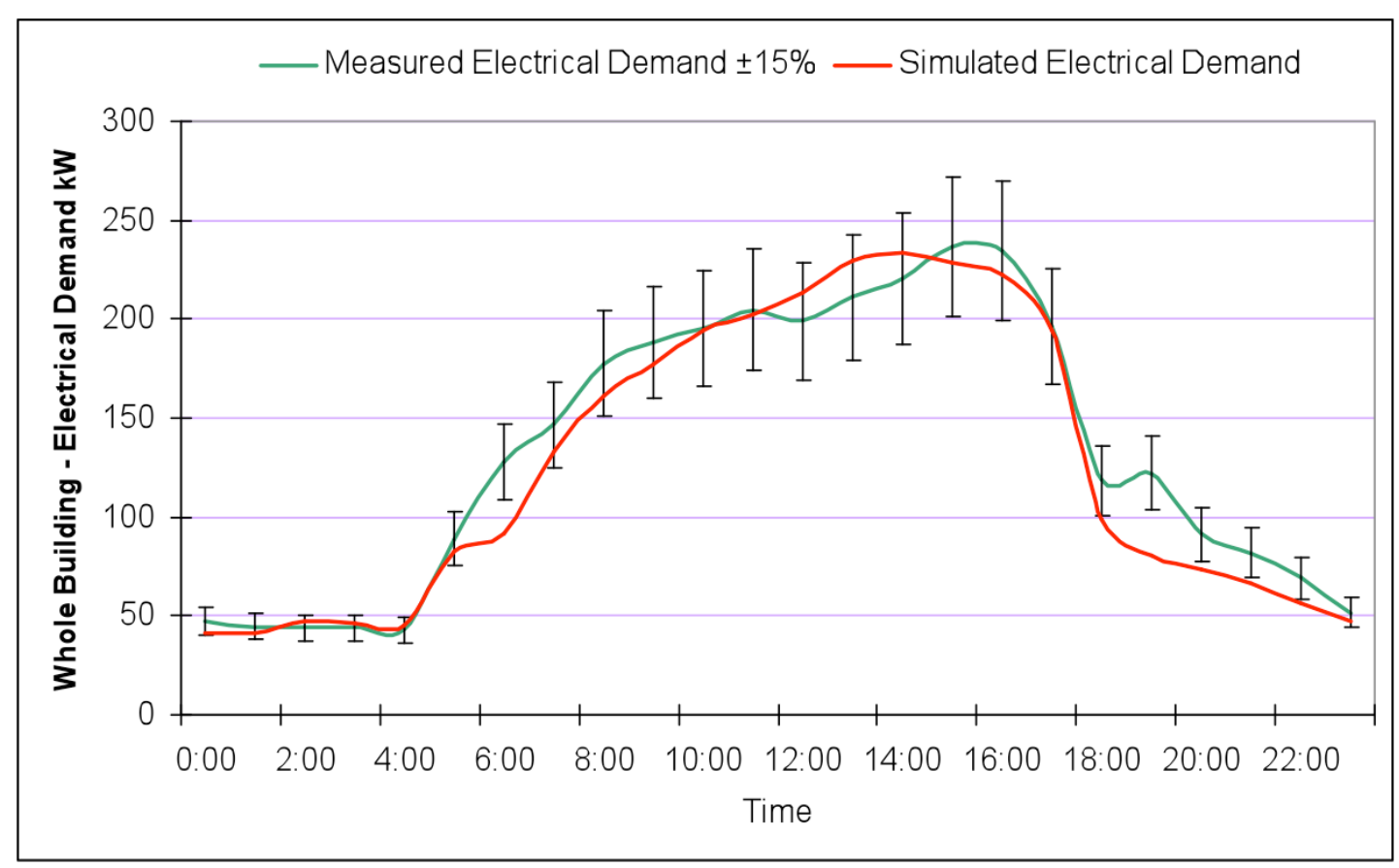

Figure C 3: Hourly Electrical Consumption of Simulation Model vs. Actual Electrical Consumption One day - Two Carnegie Plaza

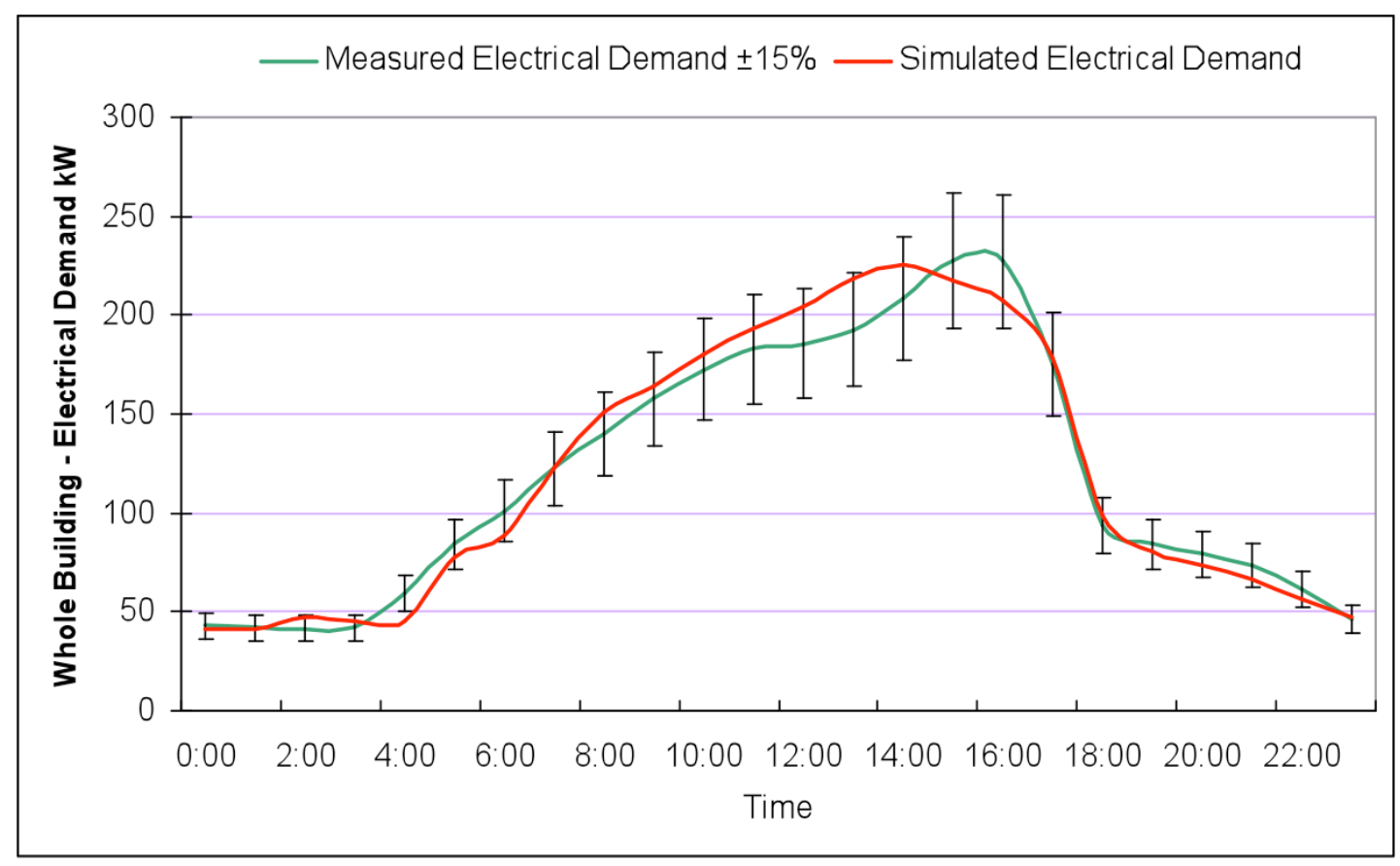

figure C 4: Hourly Electrical Consumption of Simulation Model vs. Actual Electrical Consumption One day - Two Carnegie Plaza 


\section{One Carneg ie Plaza}

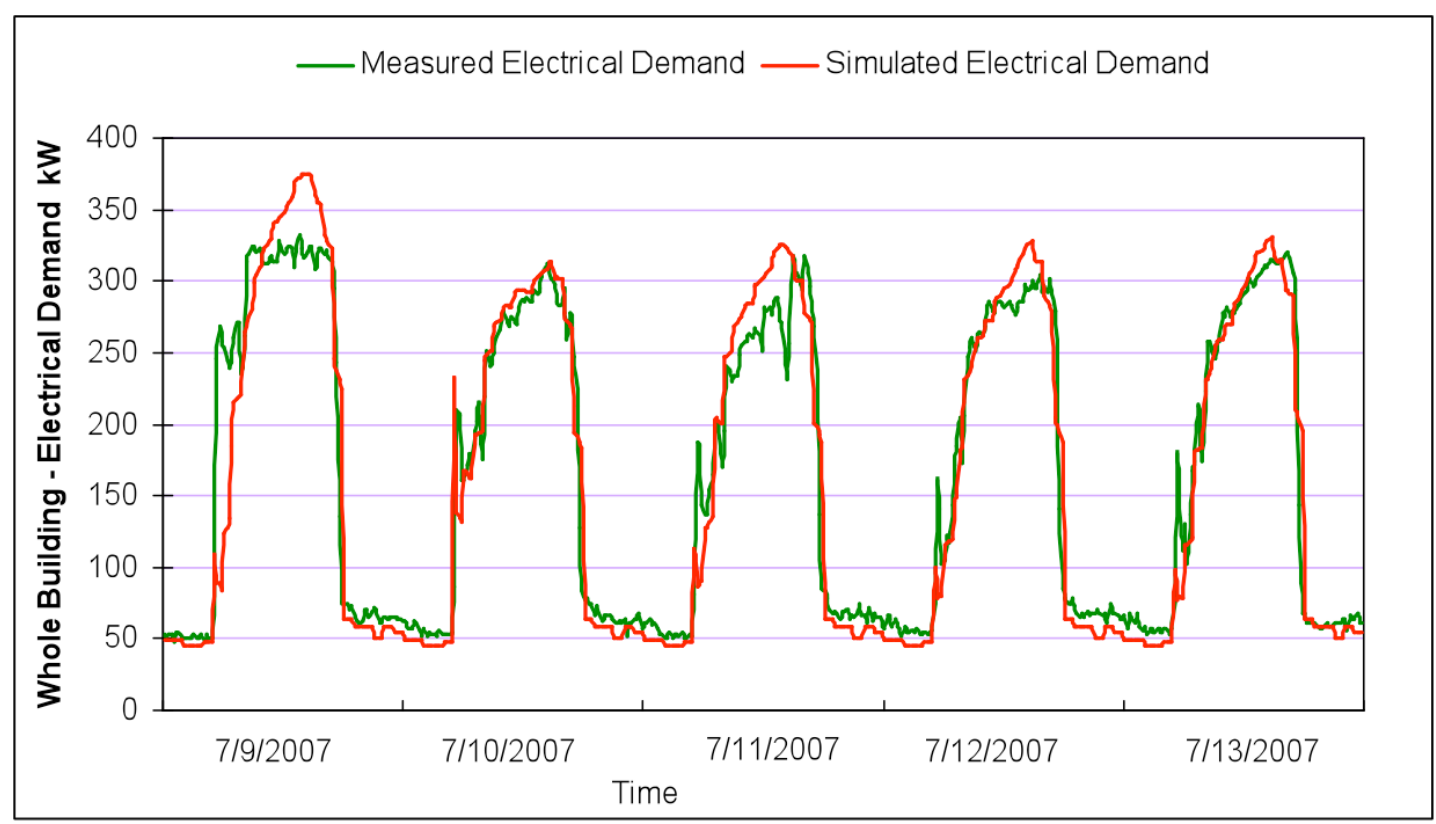

Figure C 5: Daily Electrical Consumption of Simulation Model vs. Actual Electrical Consumption in July - One Carnegie Plaza

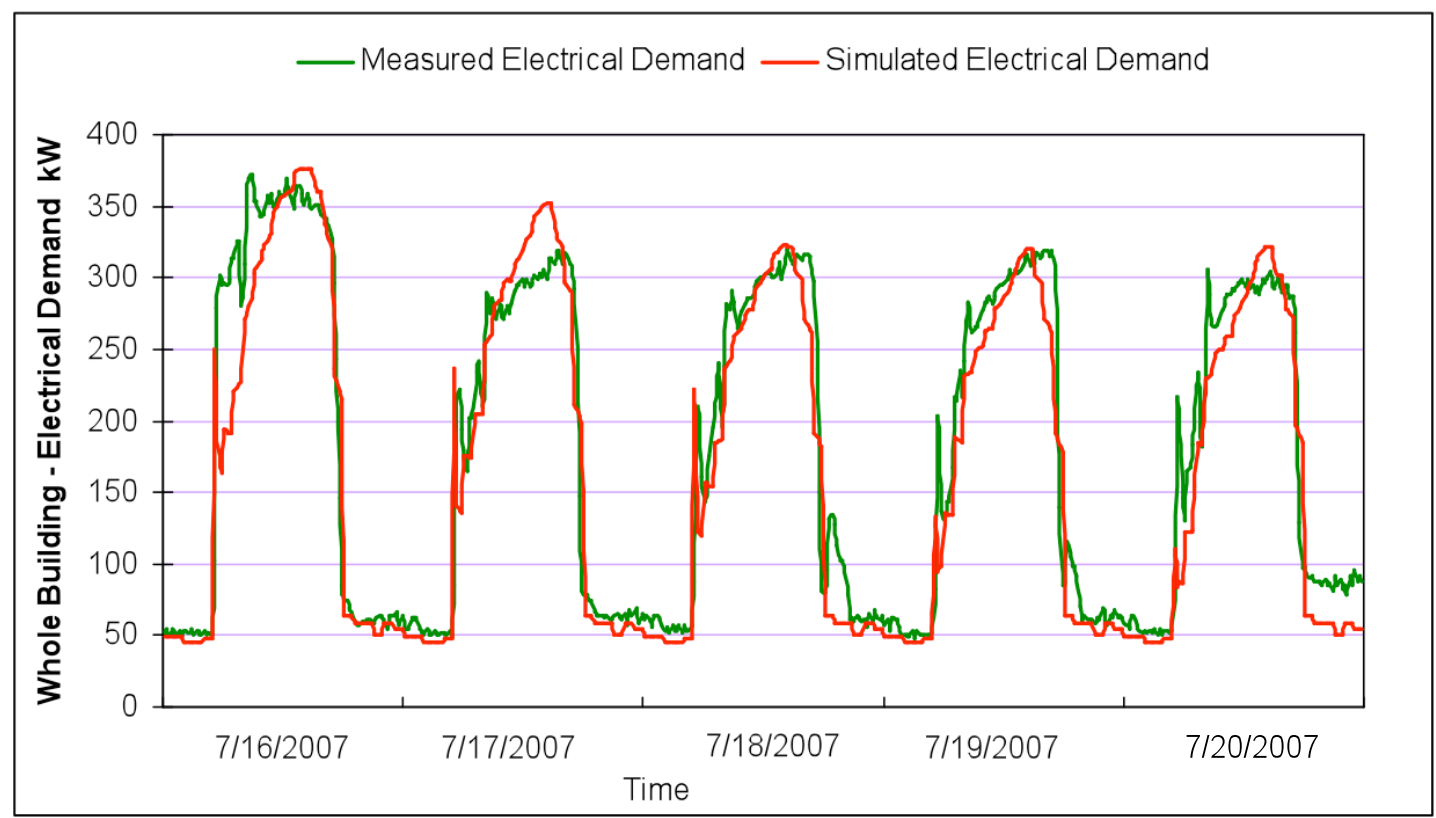

Figure C 6: Daily Electrical Consumption of Simulation Model vs. Actual Electrical Consumption in July - One Carnegie Plaza 


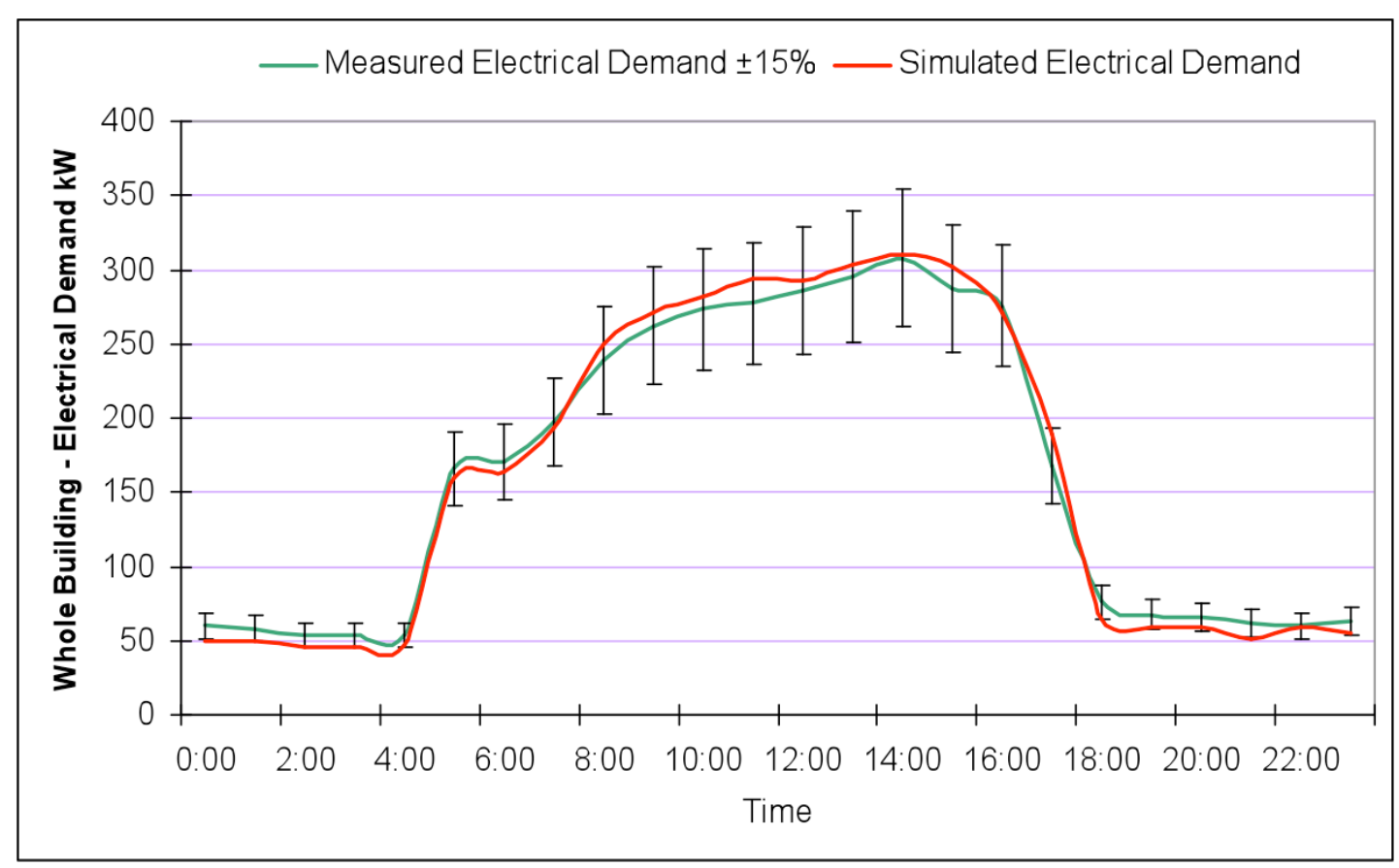

Figure C 7: Hourly Electrical Consumption of Simulation Model vs. Actual Electrical Consumption One day - One Carnegie Plaza

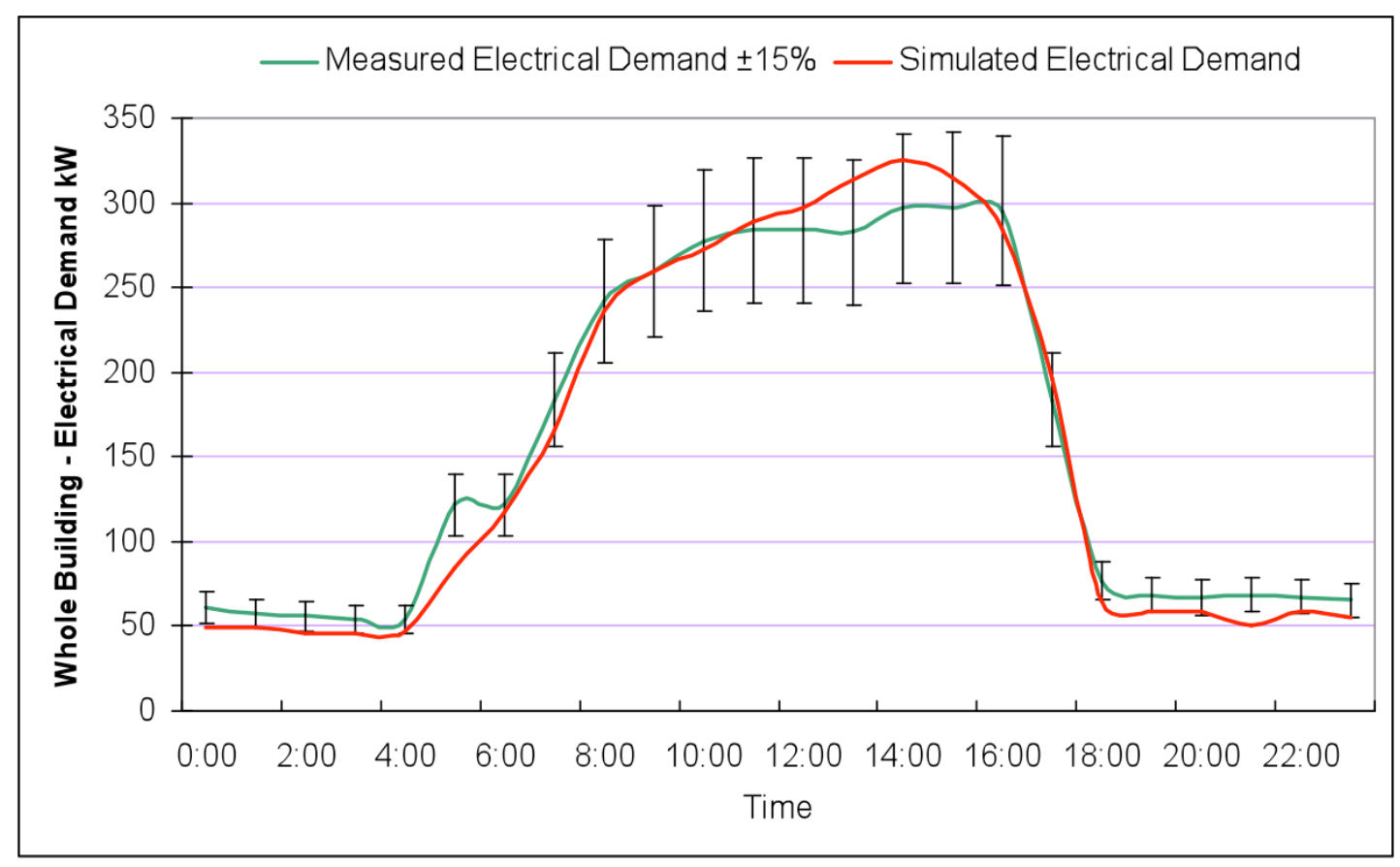

Figure C 8: Hourly Electrical Consumption of Simulation Model vs. Actual Electrical Consumption One day - One Carnegie Plaza 
One Carnegie Plaza (smauer building)

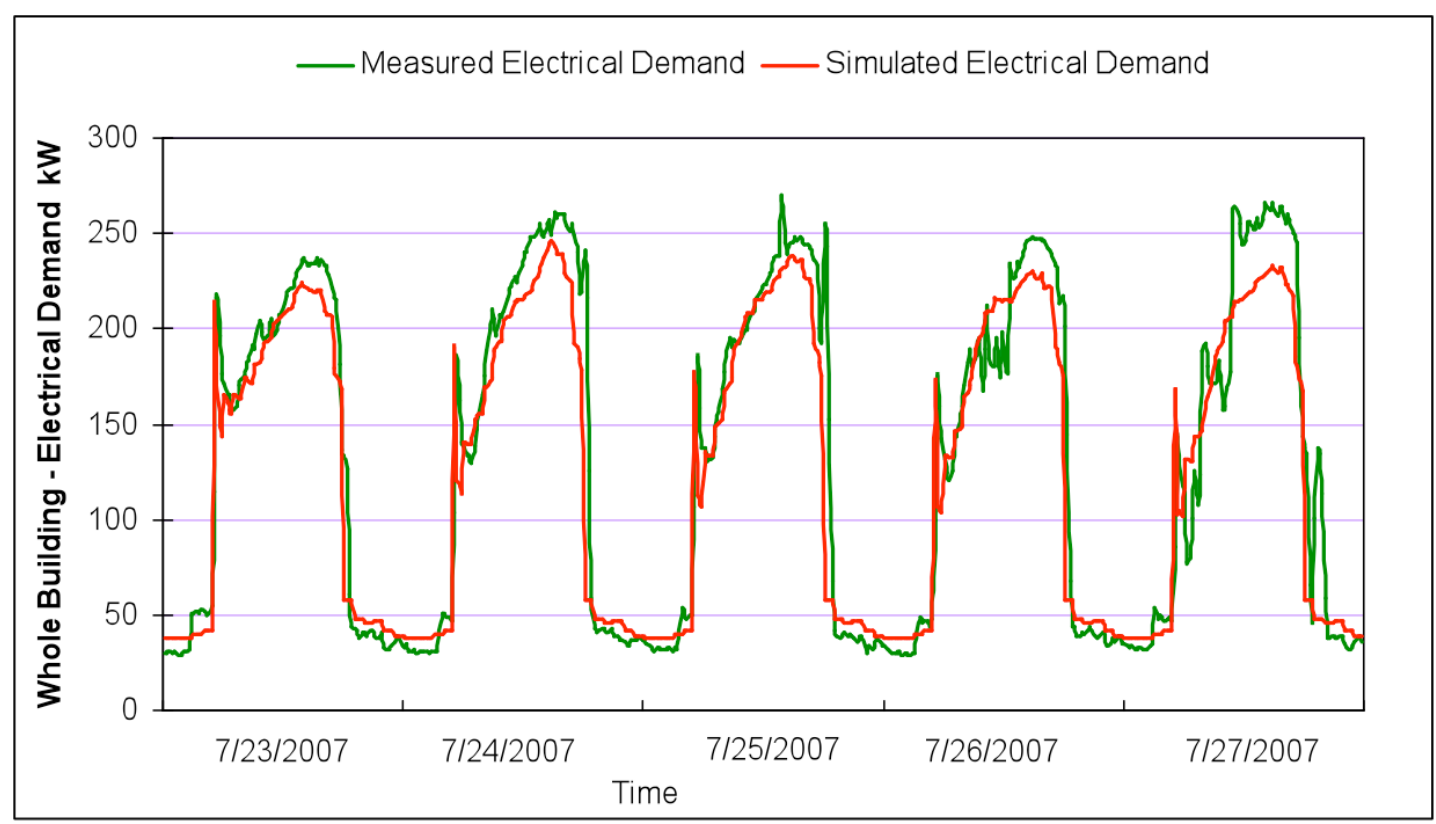

Figure C 9: Daily Electrical Consumption of Simulation Model vs. Actual Electrical Consumption in July - One Garnegie Plaza (smaller building)

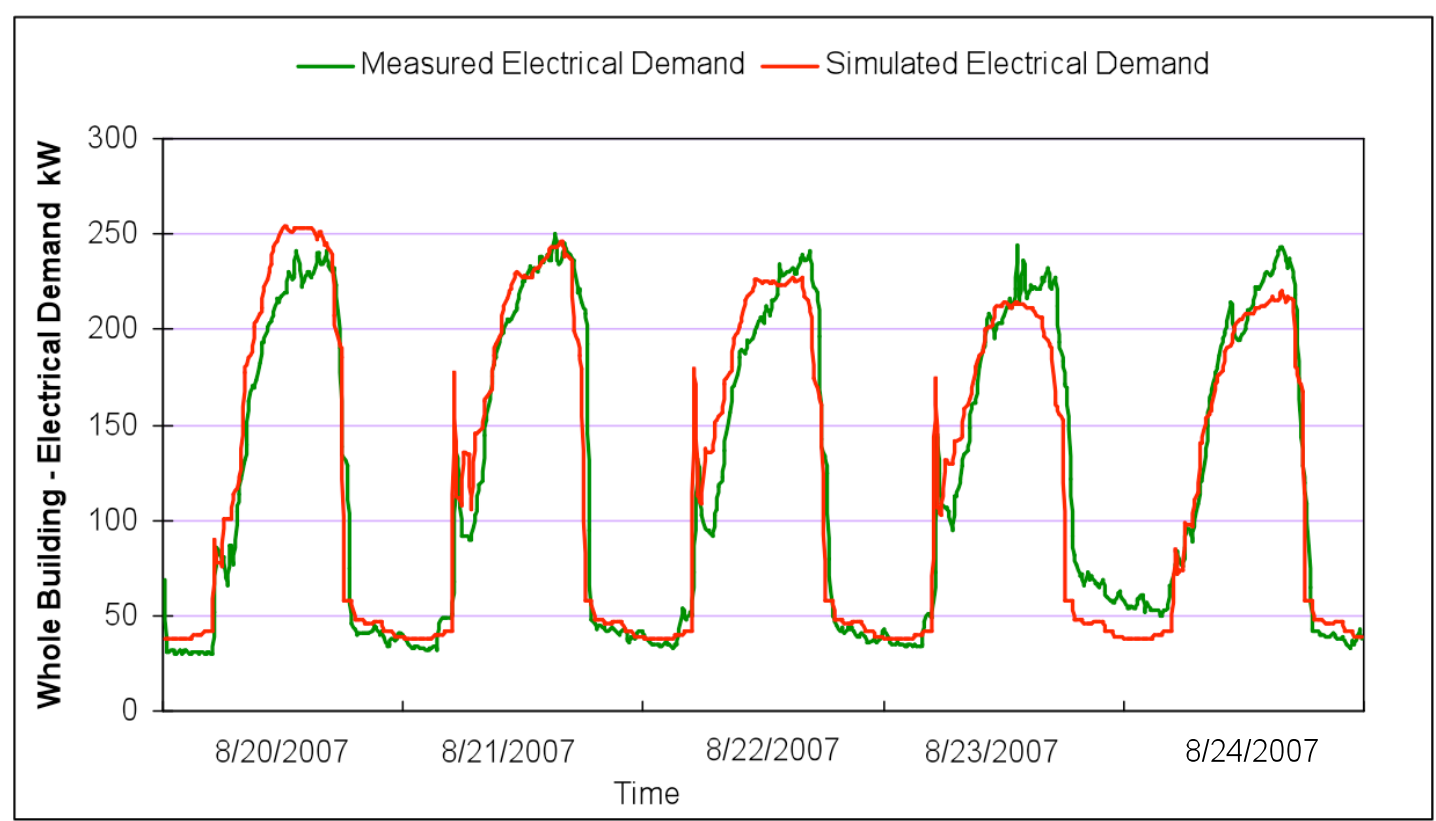

Figure C 10: Daily Electrical Consumption of Simulation Model vs. Actual Electrical Consumption in July - One Carnegie Plaza (smaller building) 


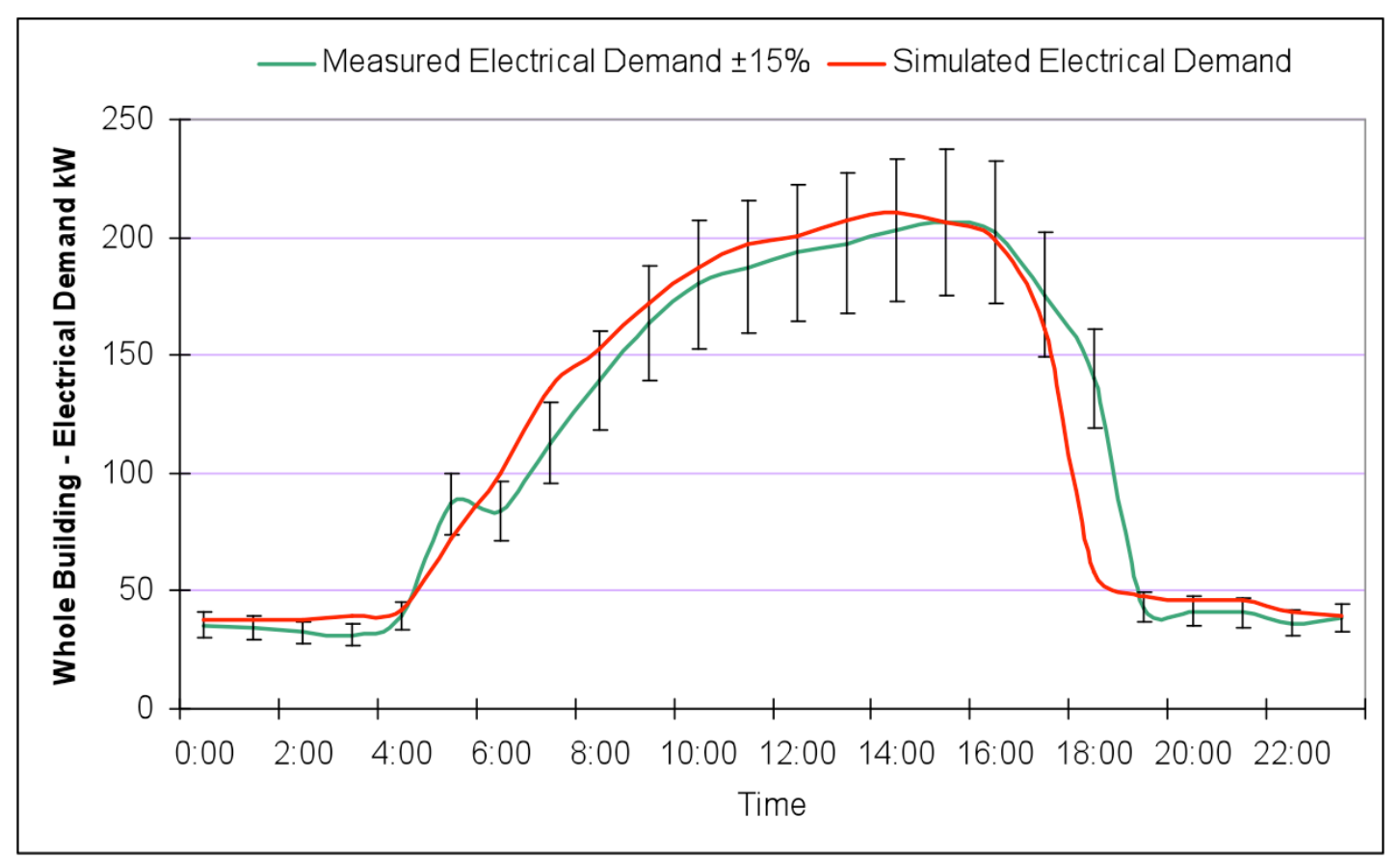

Figure C 11: Hourly Electrical Consumption of Simulation Model vs. Actual Electrical Consumption One day - One Carnegie Plaza (smaller building)

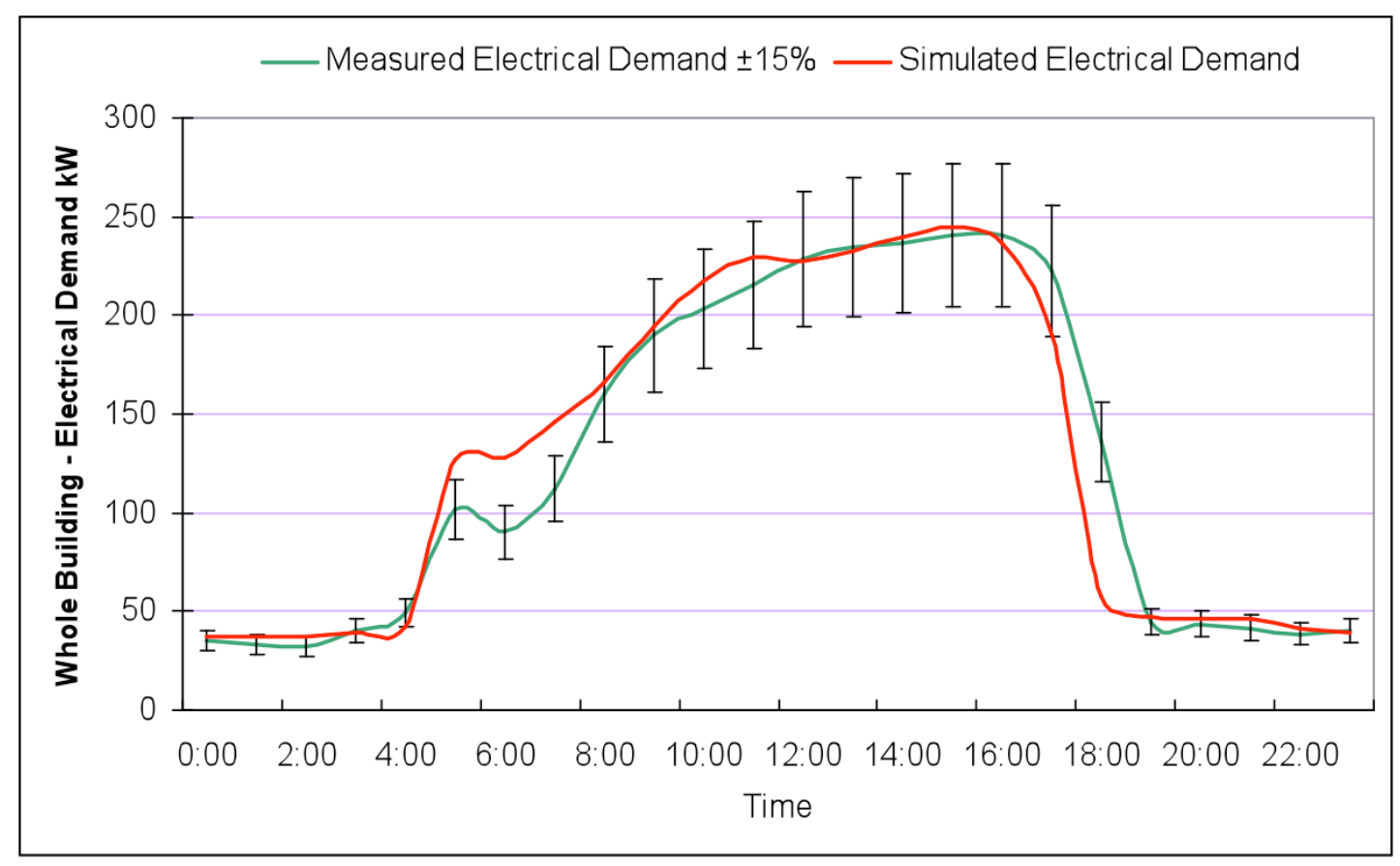

Figure C 12: Hourly Electrical Consumption of Simulation Model vs. Actual Electrical Consumption One day - One Carnegie Plaza (smaller building) 


\section{One VANDERBILt}

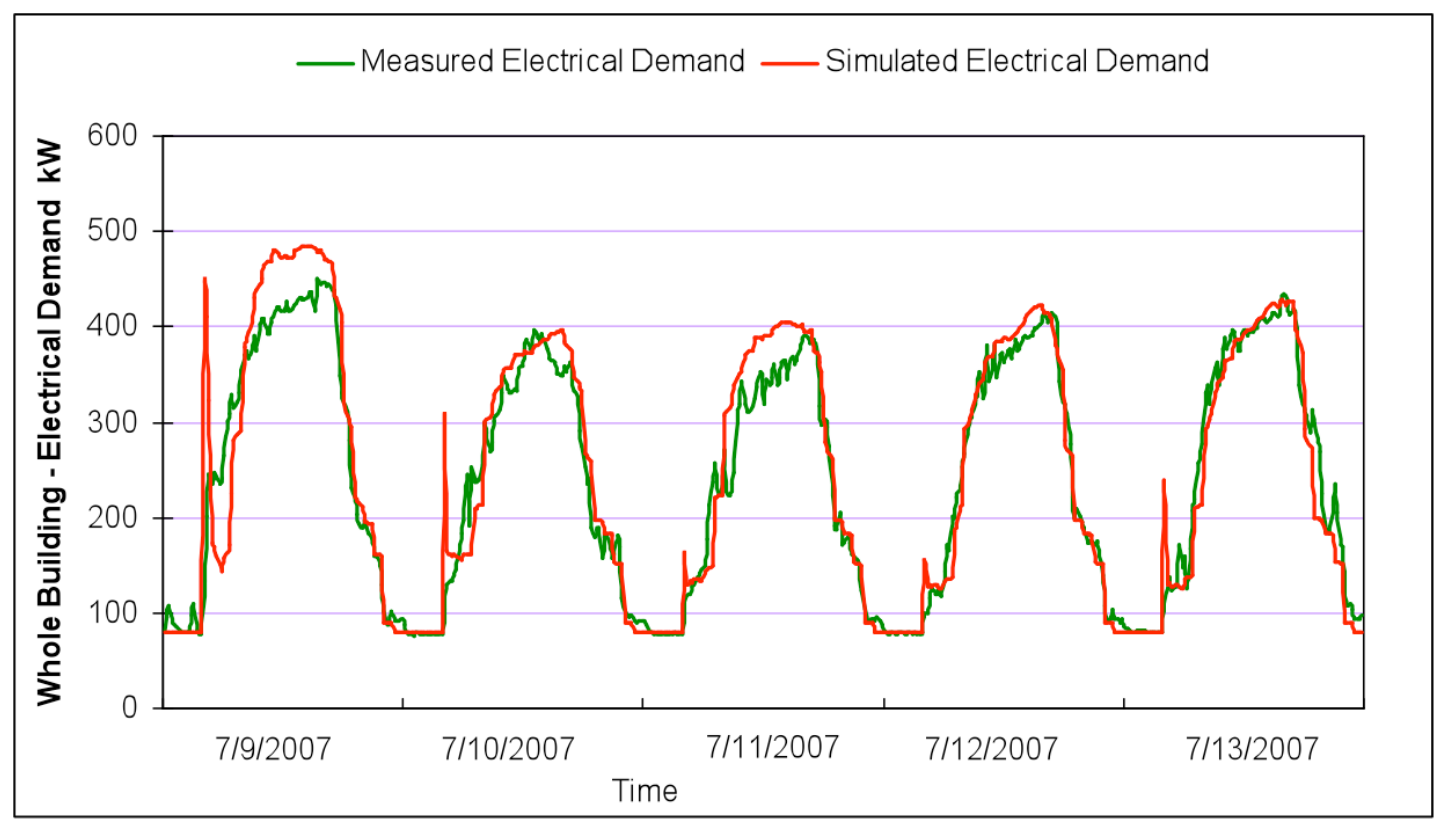

Figure C 13: Daily Electrical Consumption of Simulation Model vs. Actual Electrical CONSUMPTiOn IN July - ONe VANDERBILt

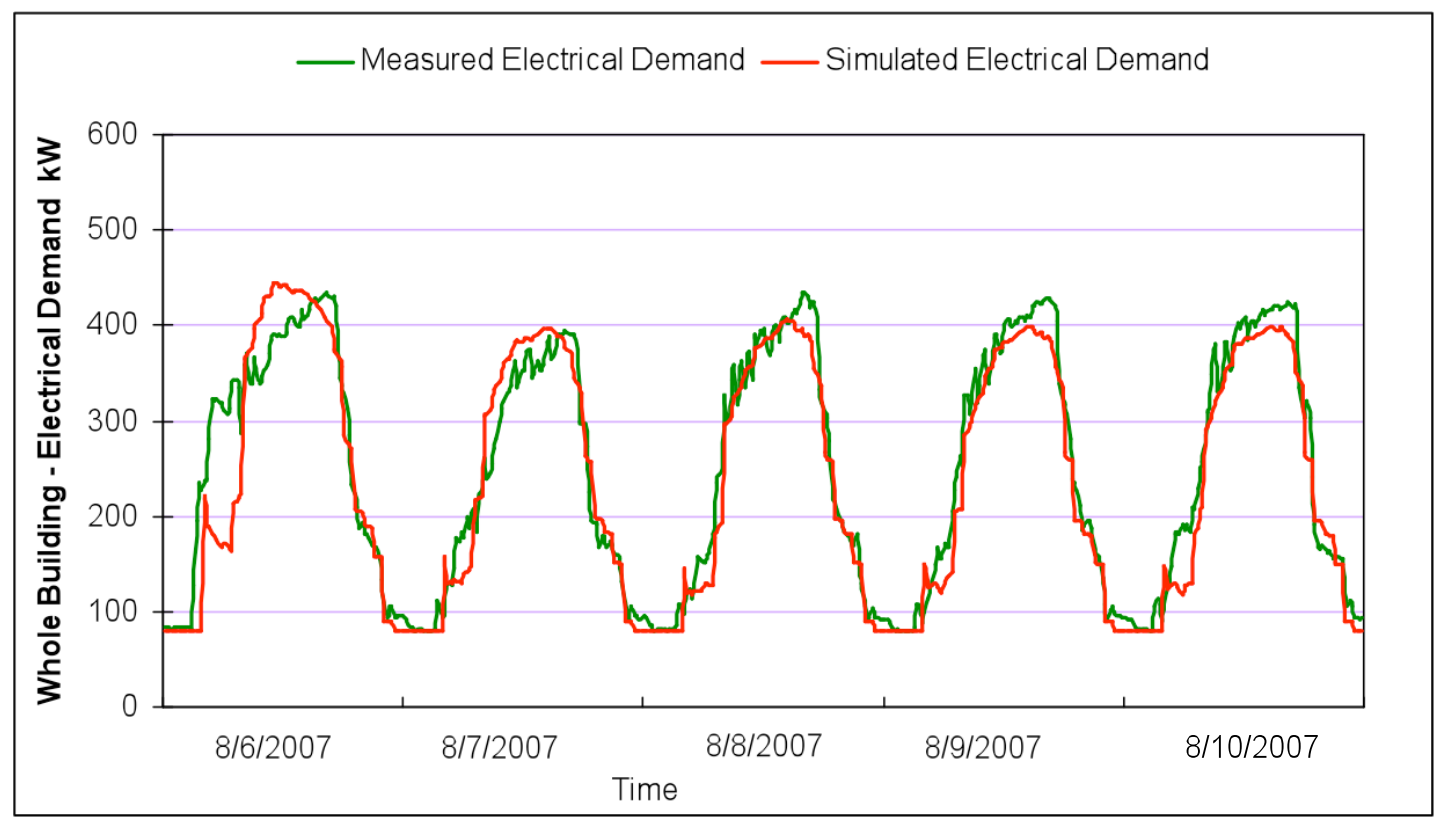

Figure C 14: Daily Electrical Consumption of Simulation Model vs. Actual Electrical CONSUMPTiOn IN July - ONe VANDERBILt 


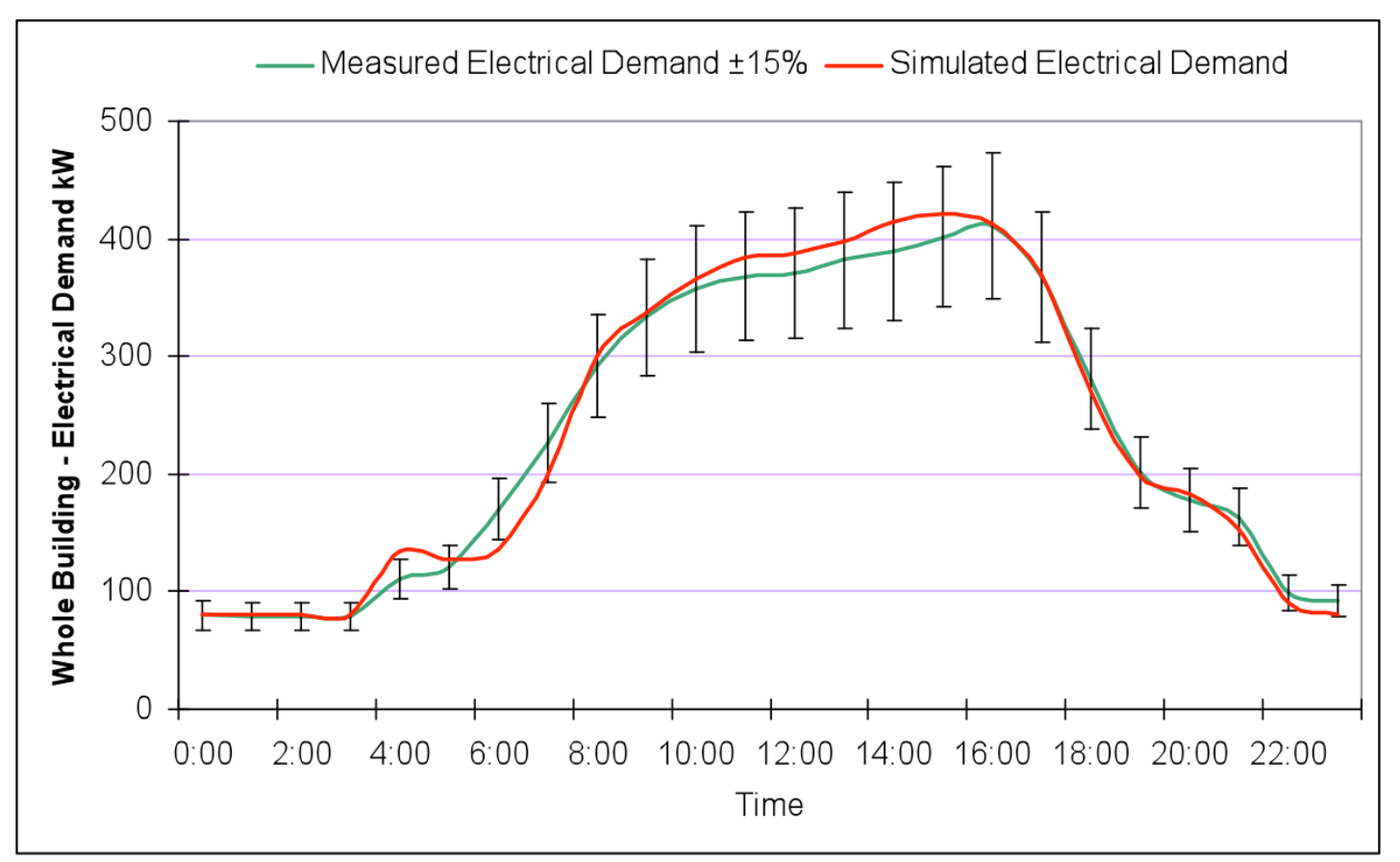

Figure C 15: Hourly Electrical Consumption of Simulation Model vs. Actual Electrical CONSUMPTION ONE DAY - ONe VANDERBILt

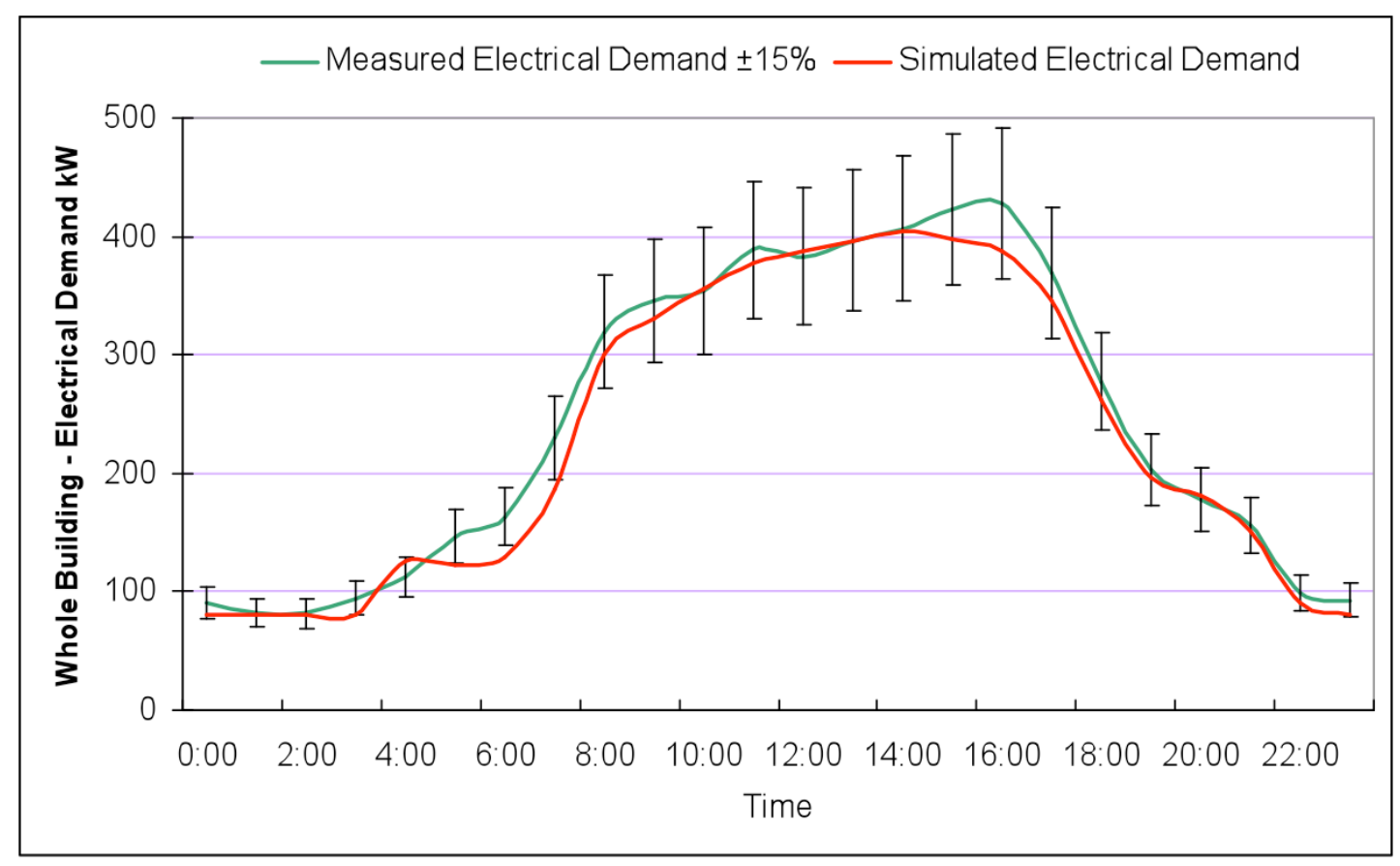

Figure C 16: Hourly Electrical Consumption of Simulation Model vs. Actual Electrical Consumption One day - ONe VANDerbilt 


\section{One PARKSIDE}

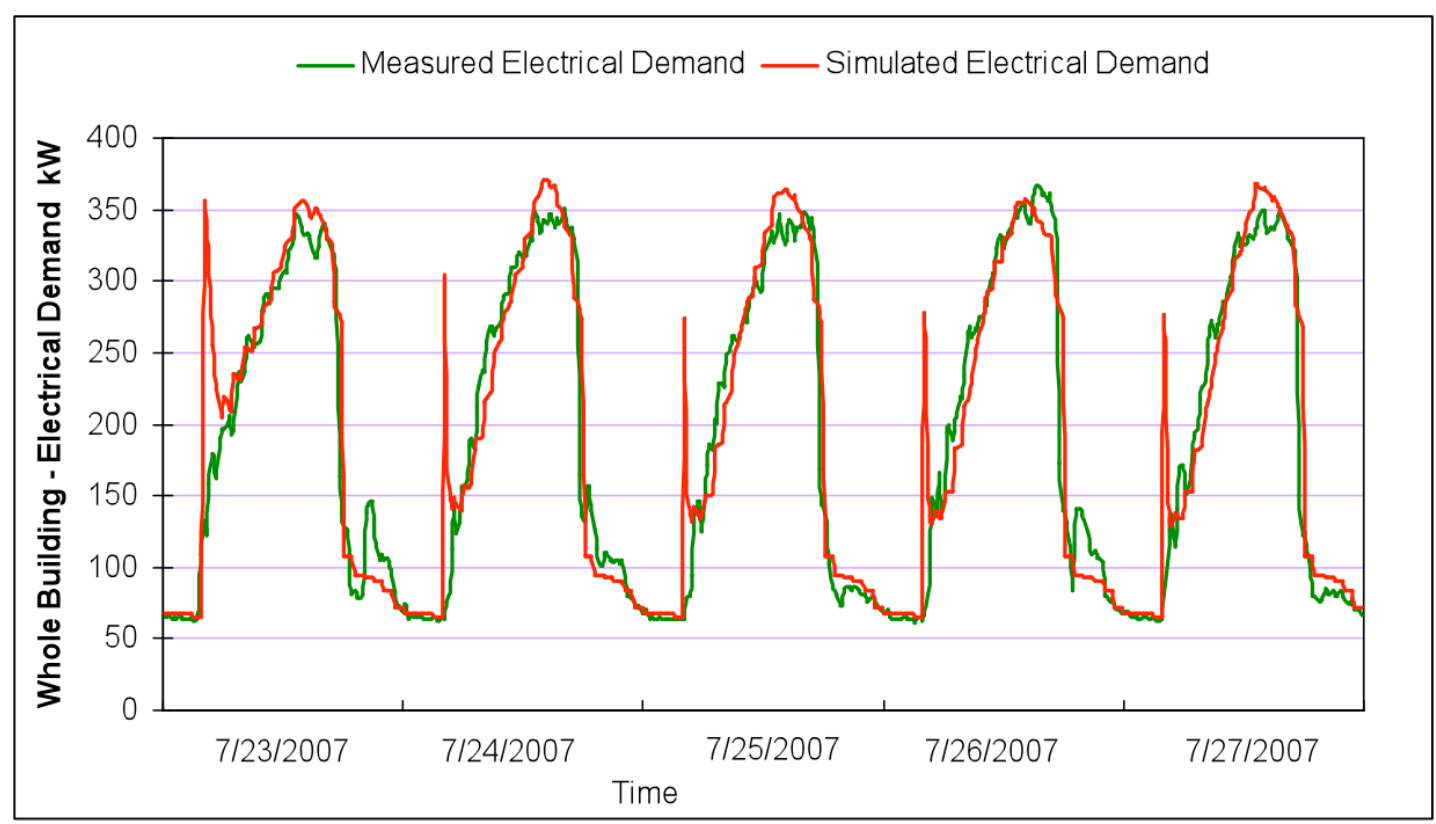

Figure C 17: Daily Electrical Consumption of Simulation Model vs. Actual Electrical Consumption in July - One Parkside

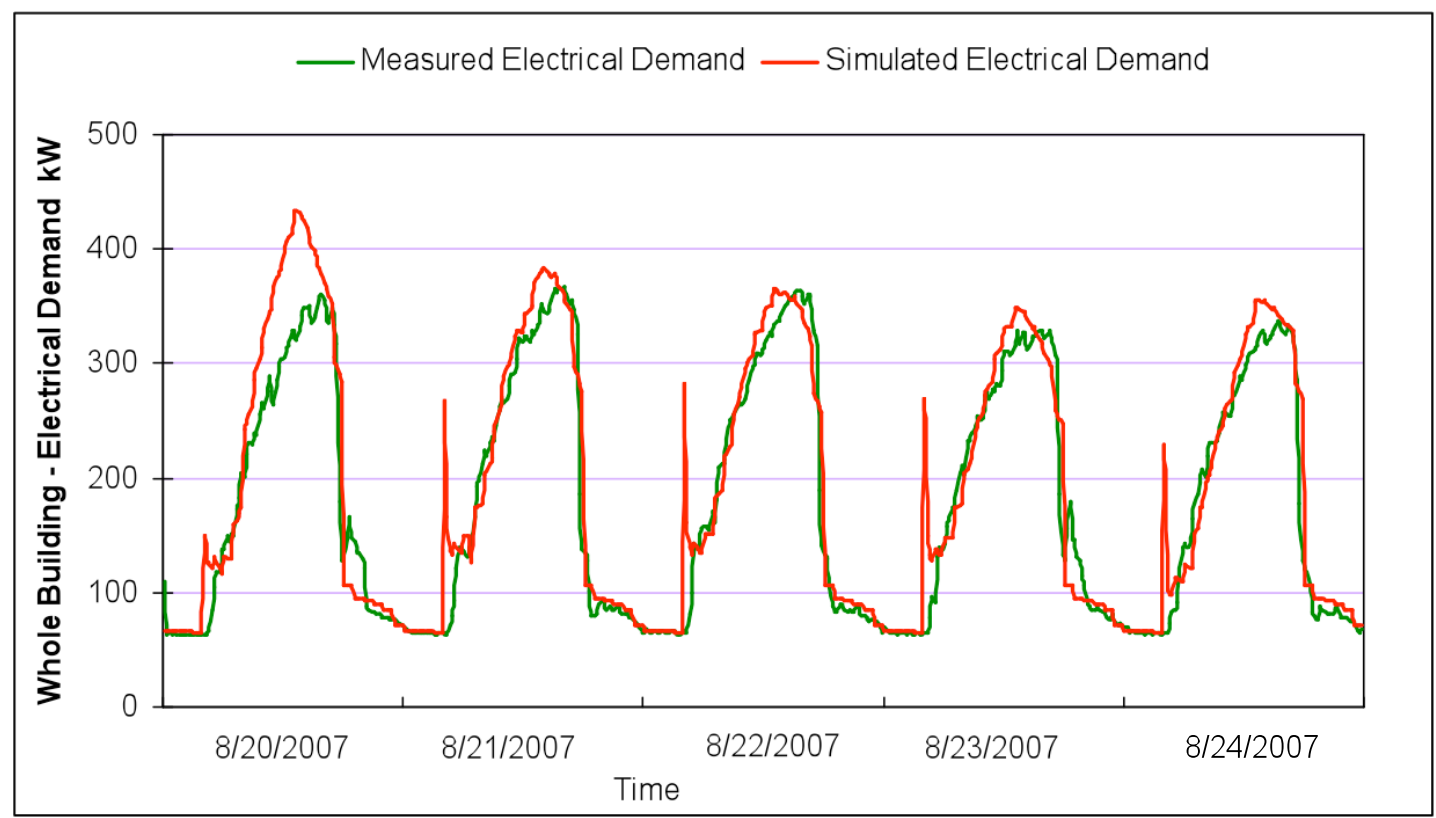

Figure C 18: Daily Electrical Consumption of Simulation Model vs. Actual Electrical Consumption in July - ONe Parkside 


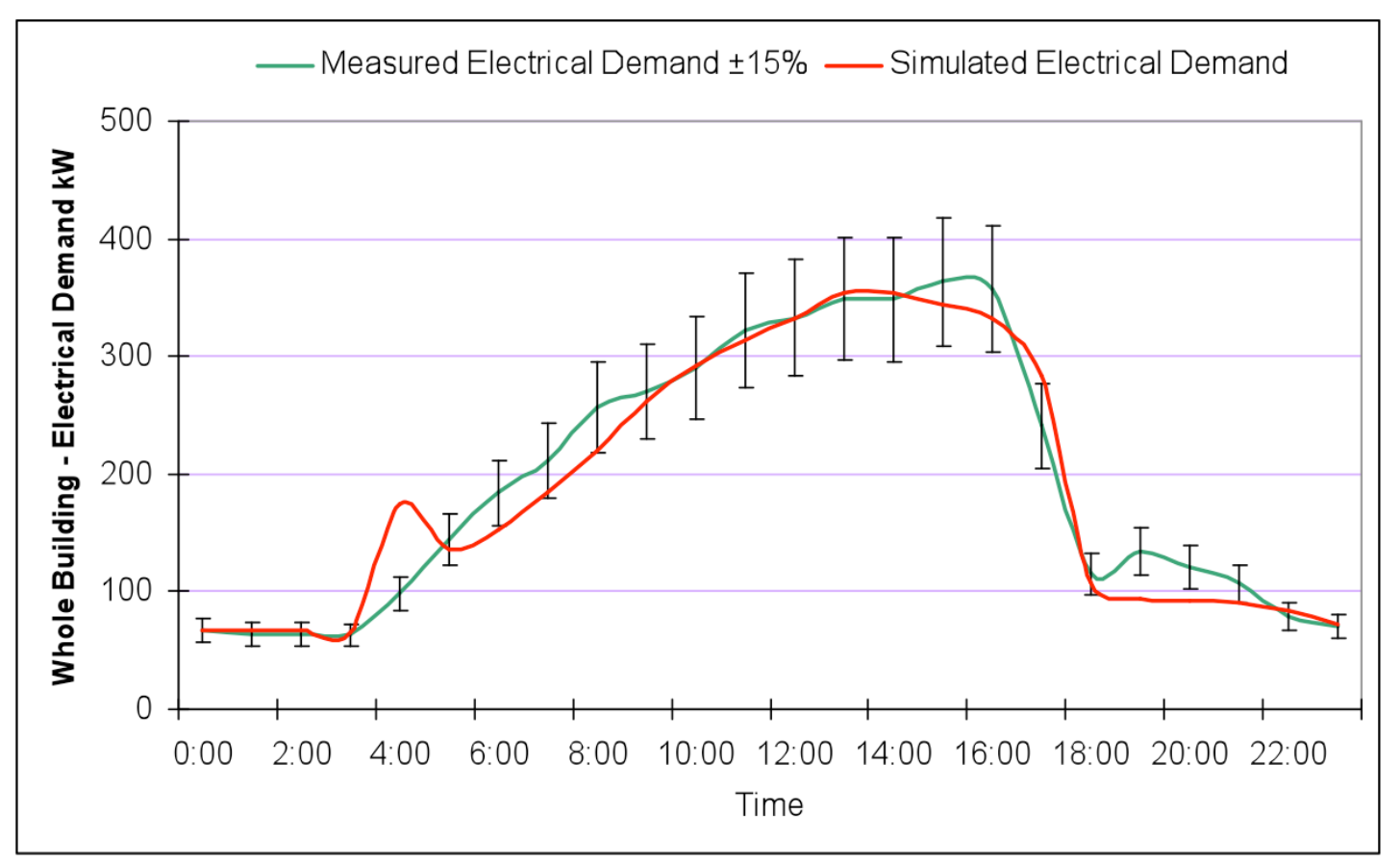

Figure C 19: Hourly Electrical Consumption of Simulation Model vs. Actual Electrical Consumption One day - One Parkside

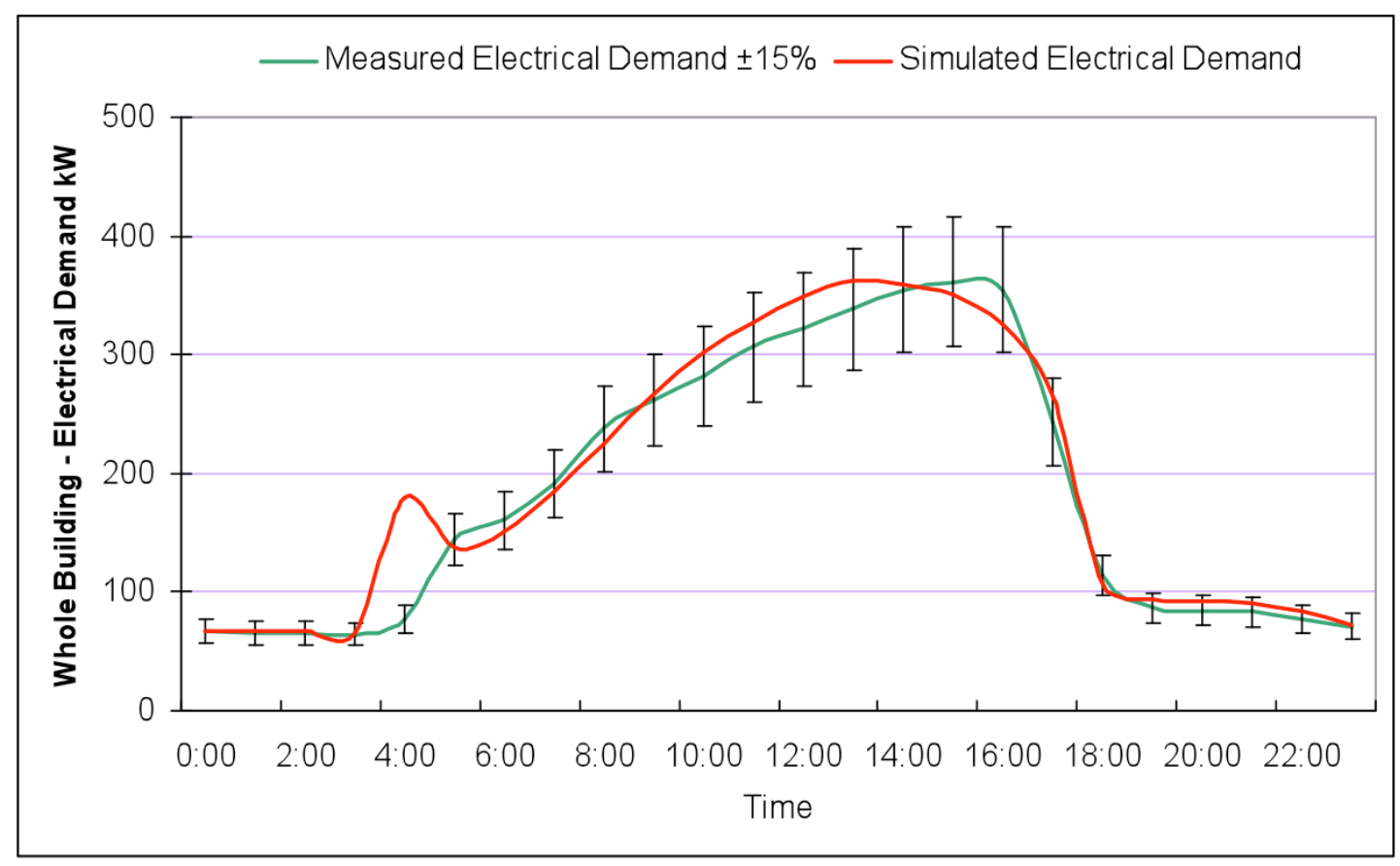

Figure C 20: Hourly Electrical Consumption of Simulation Model vs. Actual Electrical Consumption One day - One Parkside 


\section{LAKESIDE TOWER}

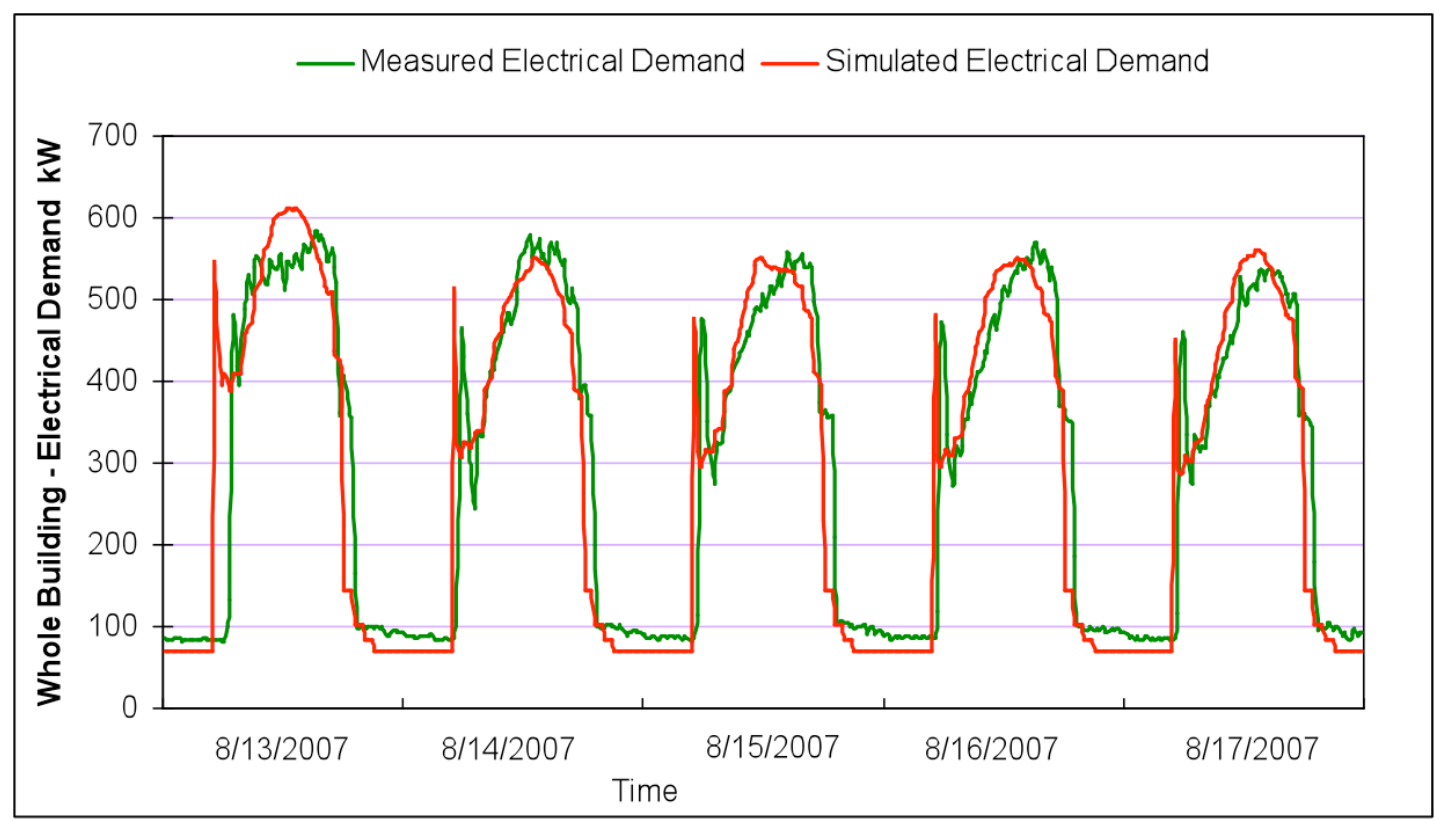

Figure C 21: Daily Electrical Consumption of Simulation Model vs. Actual Electrical CONSUMPTION IN JULY - LAKESIDE TOWER

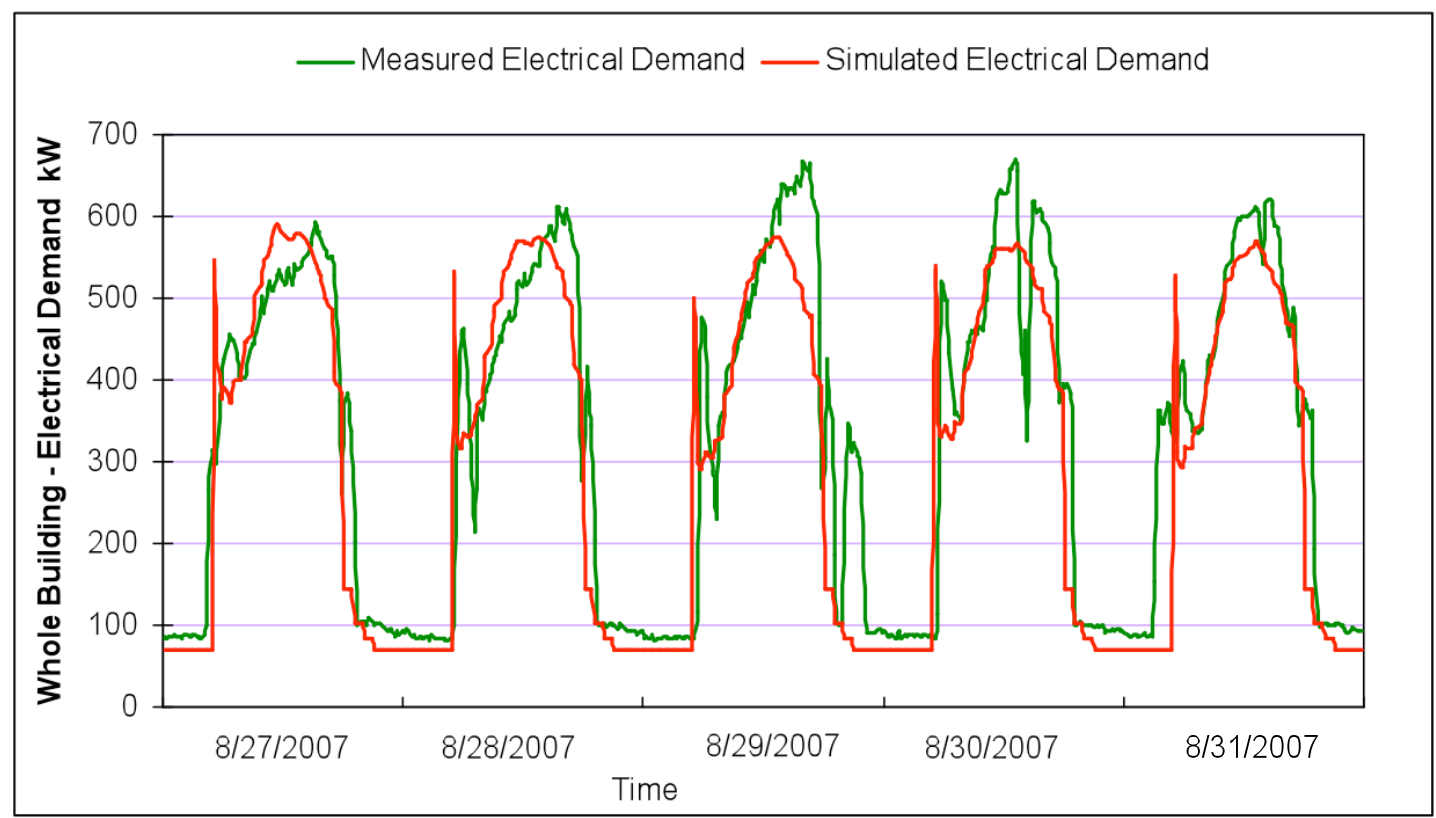

Figure C 22: Daily Electrical Consumption of Simulation Model vs. Actual Electrical CONSUMPTION IN JULY - LAKESIDE TOWER 


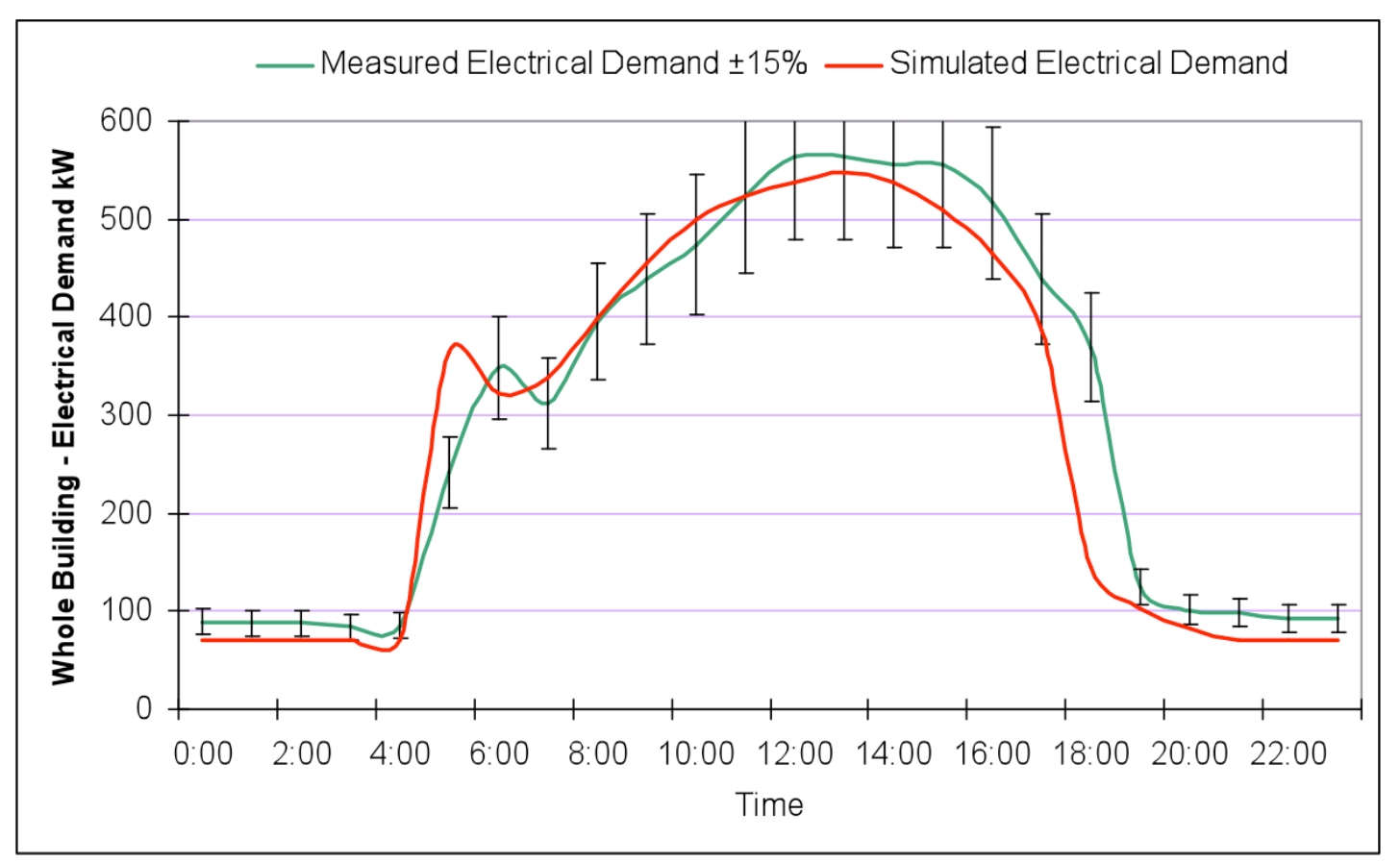

Figure C 23: Hourly Electrical Consumption of Simulation Model vs. Actual Electrical CONSUMPTION ONE DAY - LAKESIDE TOWER

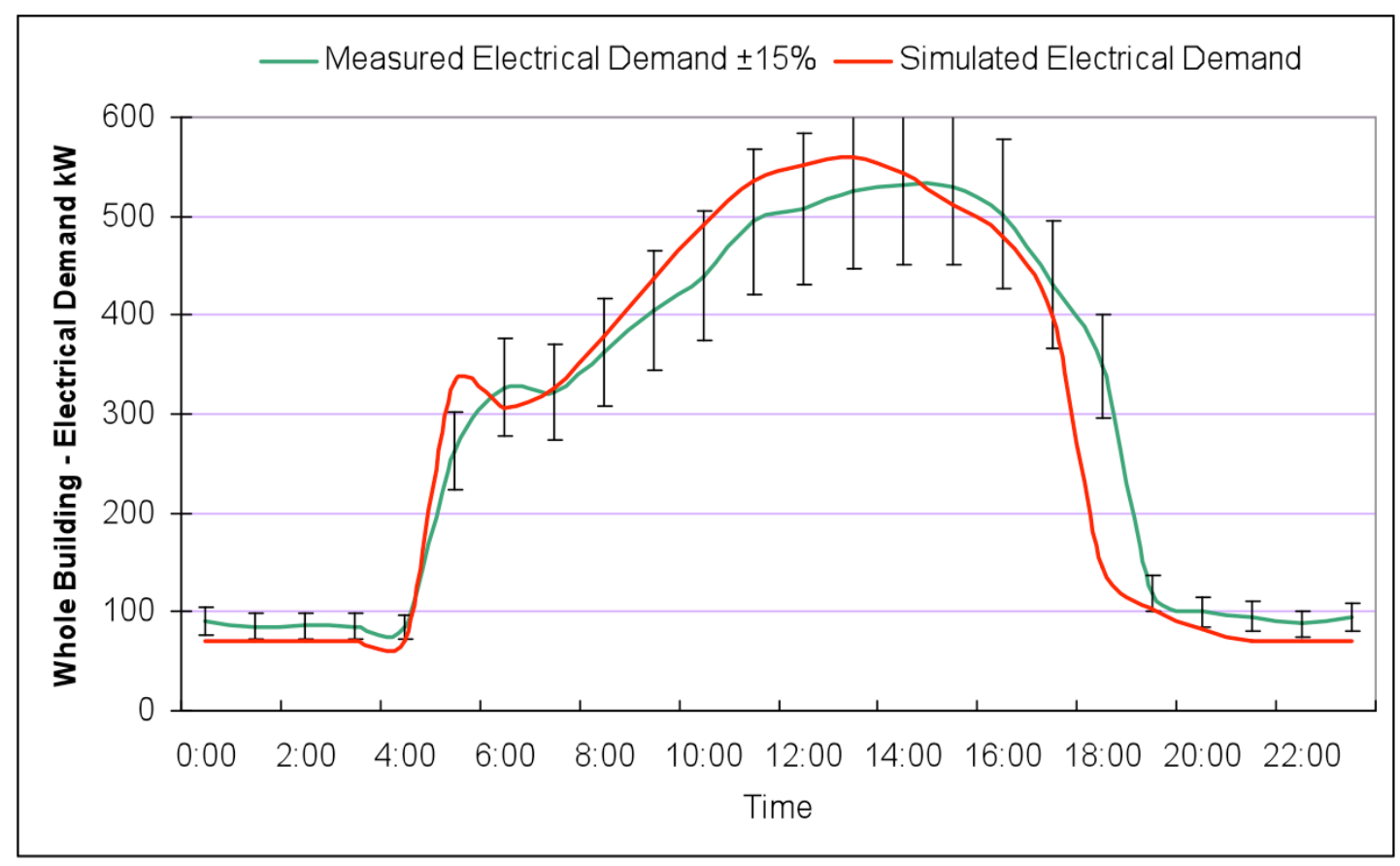

Figure C 24: Hourly Electrical Consumption of Simulation Model vs. Actual Electrical CONSUMPTION ONE dAY - LAKESIDE TOWER 


\section{Two PARKSIDE}

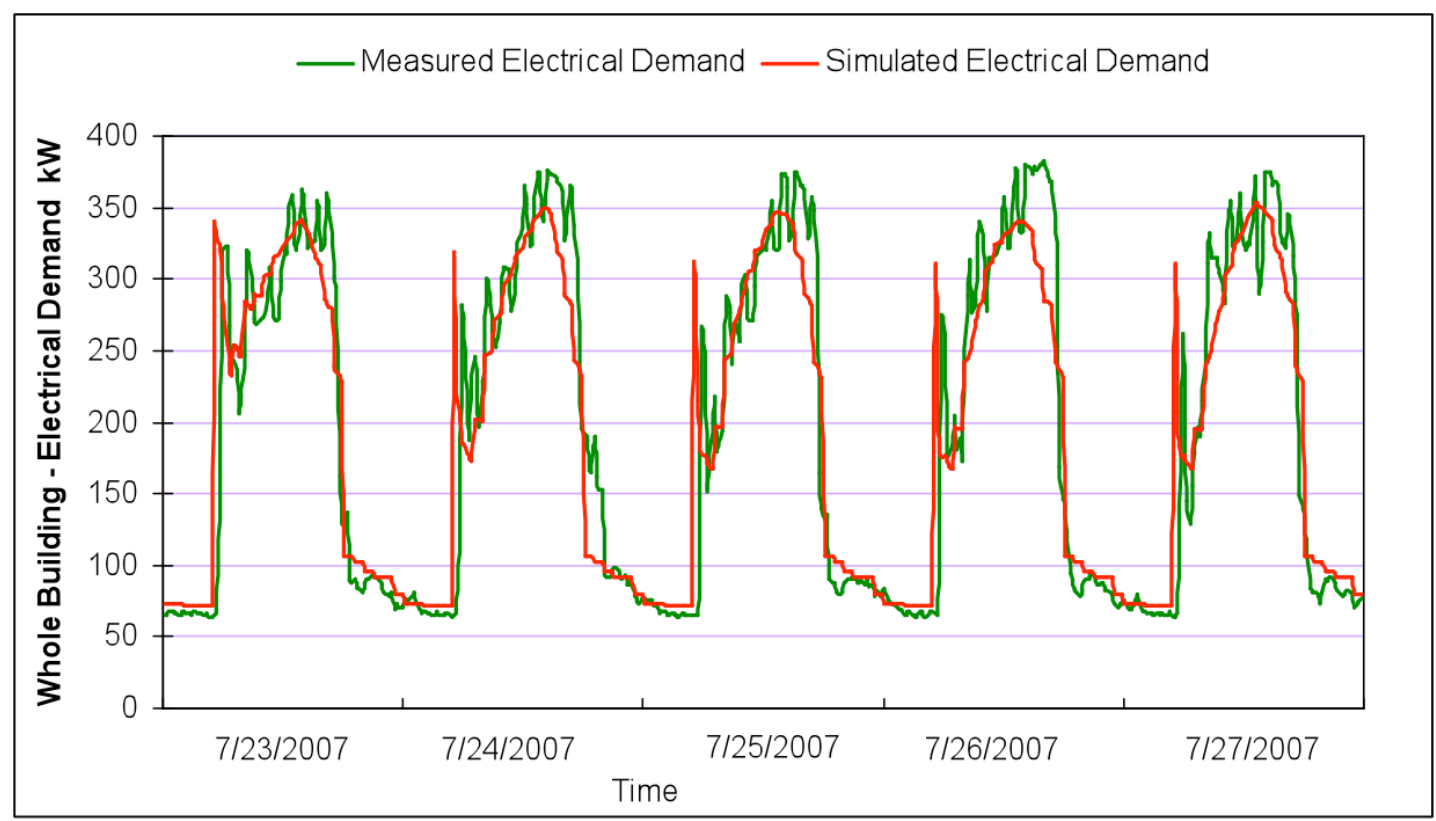

Figure C 25: Daily Electrical Consumption of Simulation Model vs. Actual Electrical Consumption IN JULY - TWO PARKside

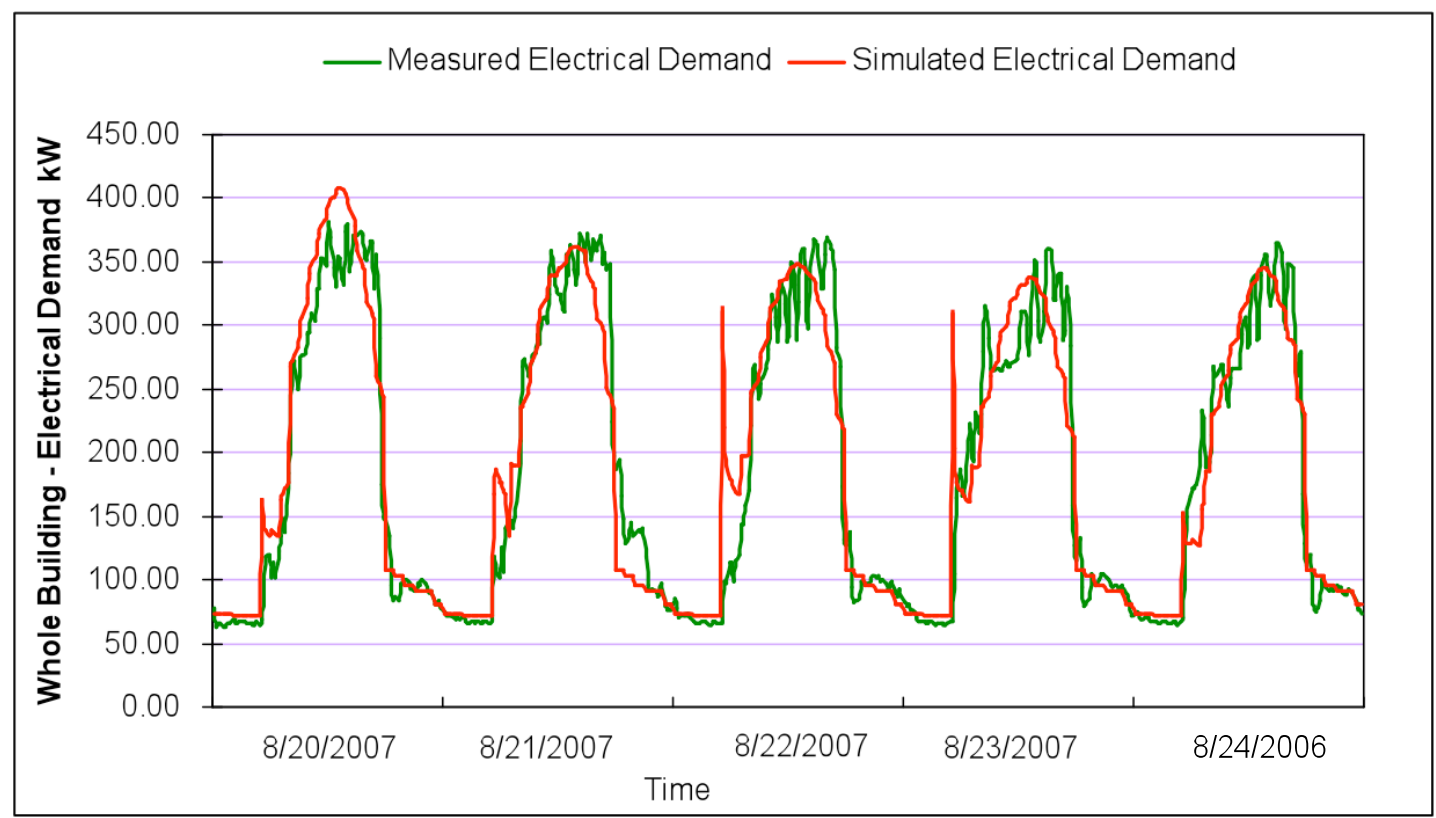

Figure C 26: Daily Electrical Consumption of Simulation Model vs. Actual Electrical Consumption in July - Two Parkside 


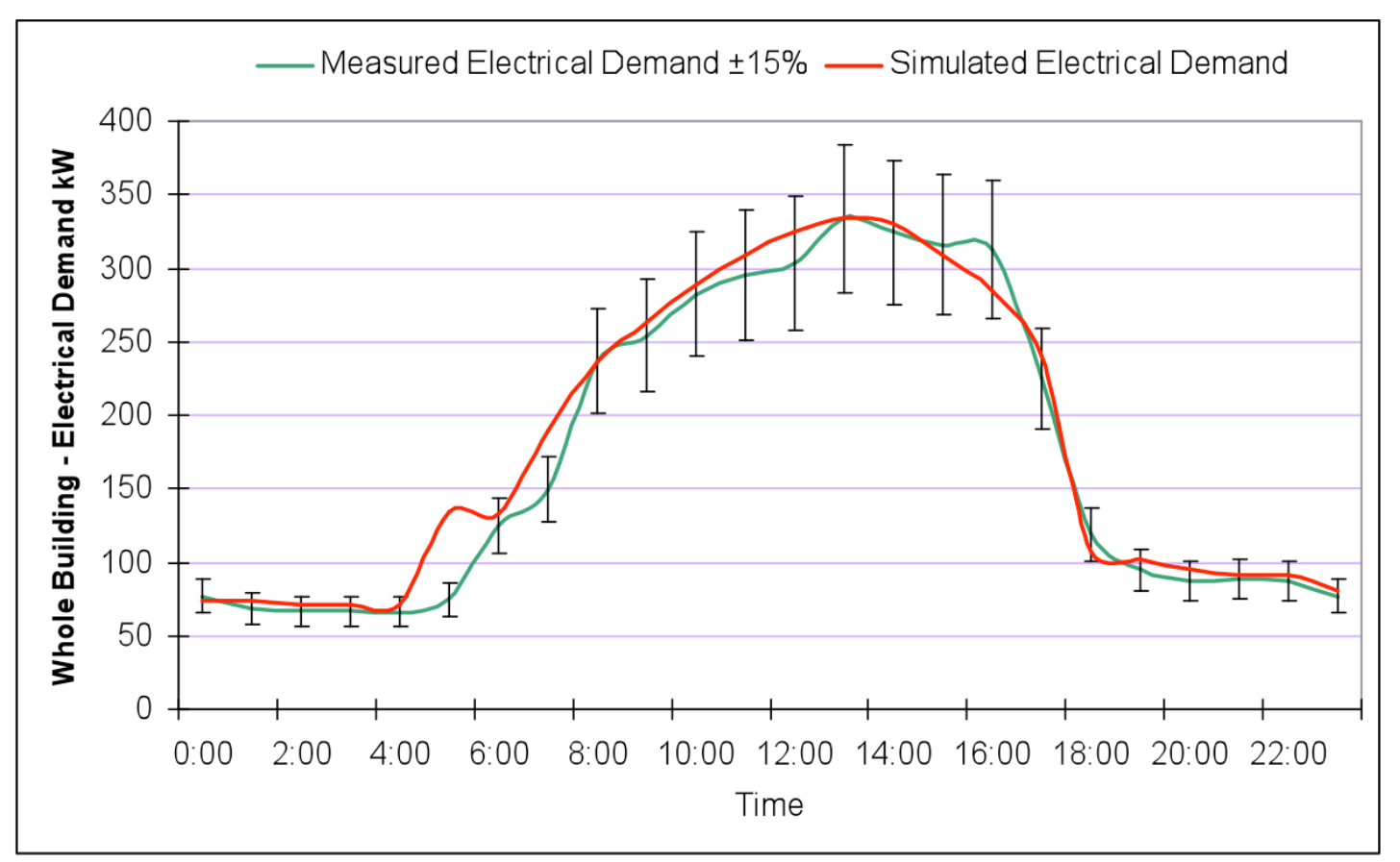

Figure C 27: Hourly Electrical Consumption of Simulation Model vs. Actual Electrical CONSUMPTION ONE DAY - TWO PARKSIDE

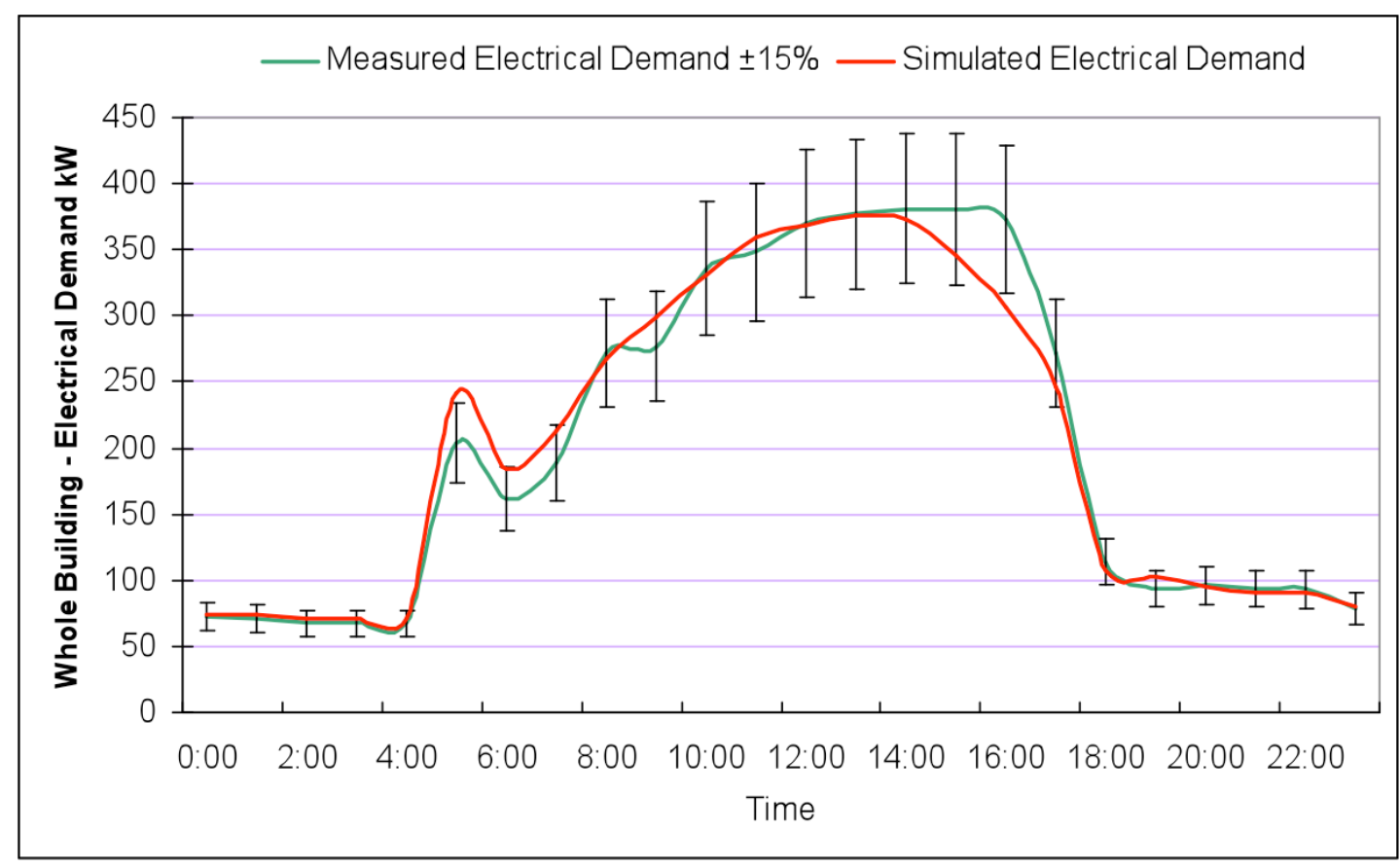

Figure C 28: Hourly Electrical Consumption of Simulation Model vs. Actual Electrical CONSUMPTION ONE daY - TWO PARKSIDE 


\section{THRee CaRNeg ie Plaza}

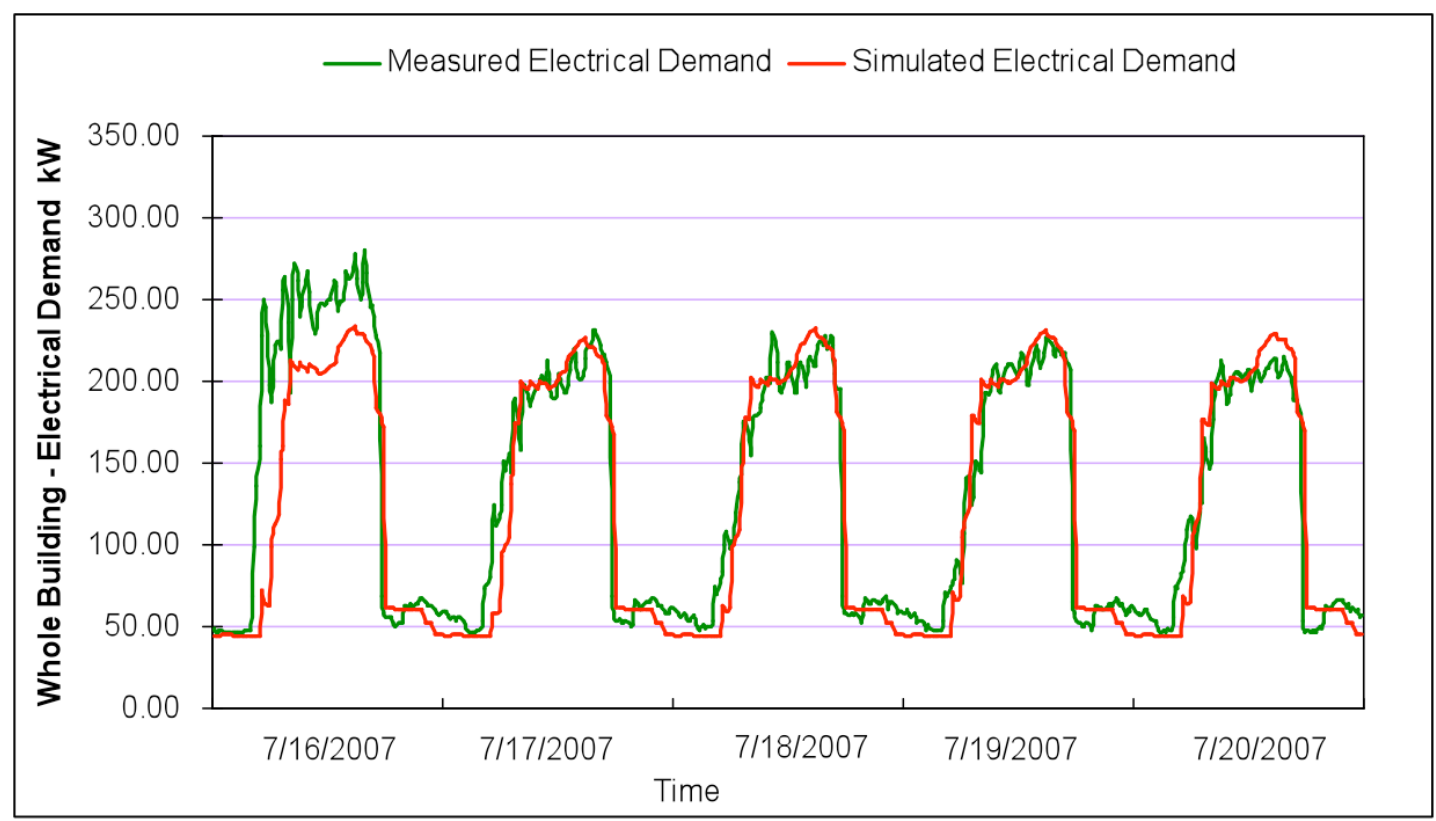

Figure C 29: Daily Electrical Consumption of Simulation Model vs. Actual Electrical Consumption IN JULY - TWO PARKside

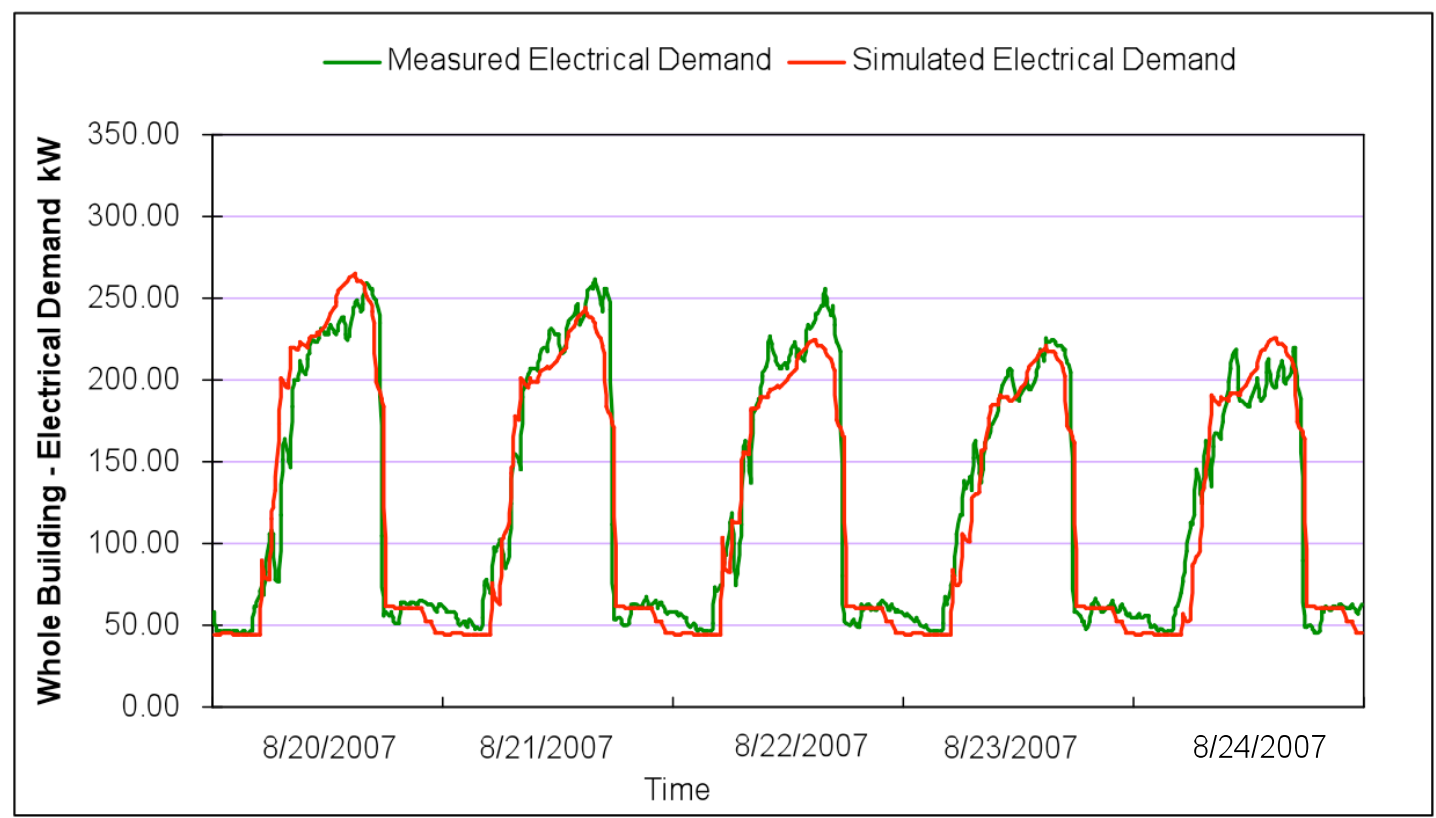

Figure C 30: Daily Electrical Consumption of Simulation Model vs. Actual Electrical Consumption IN July - Two Parkside 


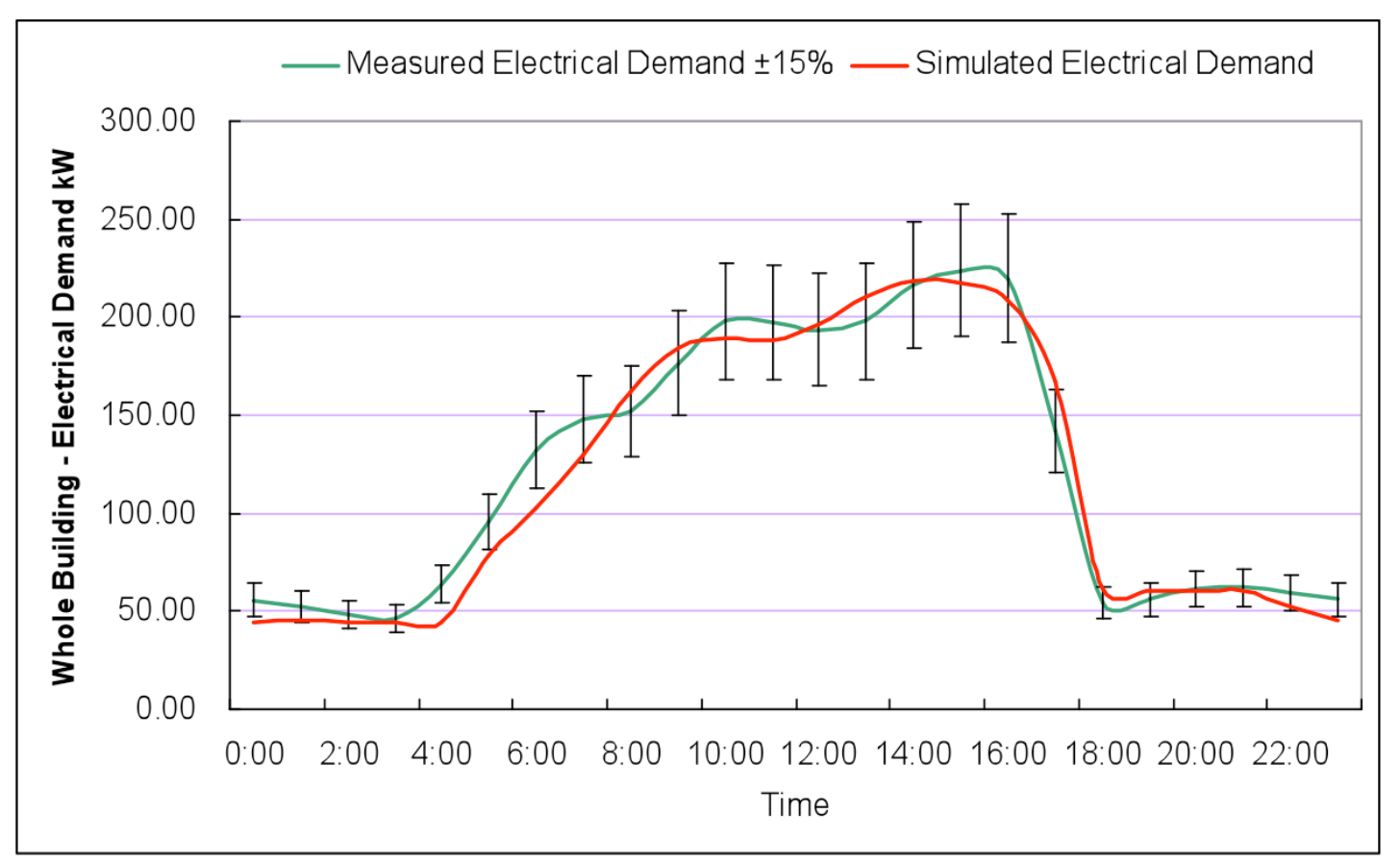

Figure C 31: Hourly Electrical Consumption of Simulation Model vs. Actual Electrical CONSUMPTION ONE DAY - TWO PARKSIDE

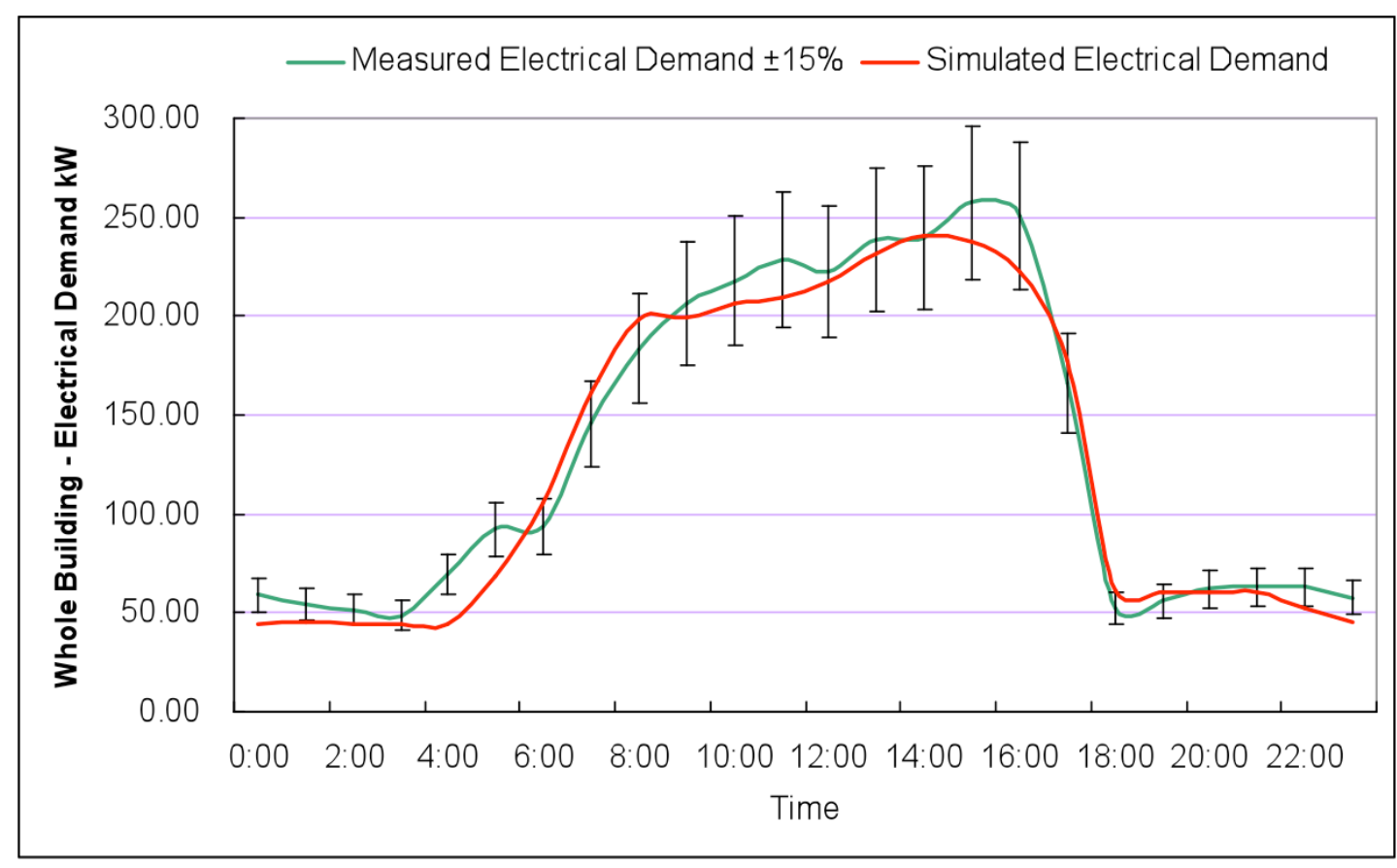

Figure C 32: Hourly Electrical Consumption of Simulation Model vs. Actual Electrical CONSUMPTION ONE daY - TWO PARKSIDE 


\section{Brigr Corporate Center}

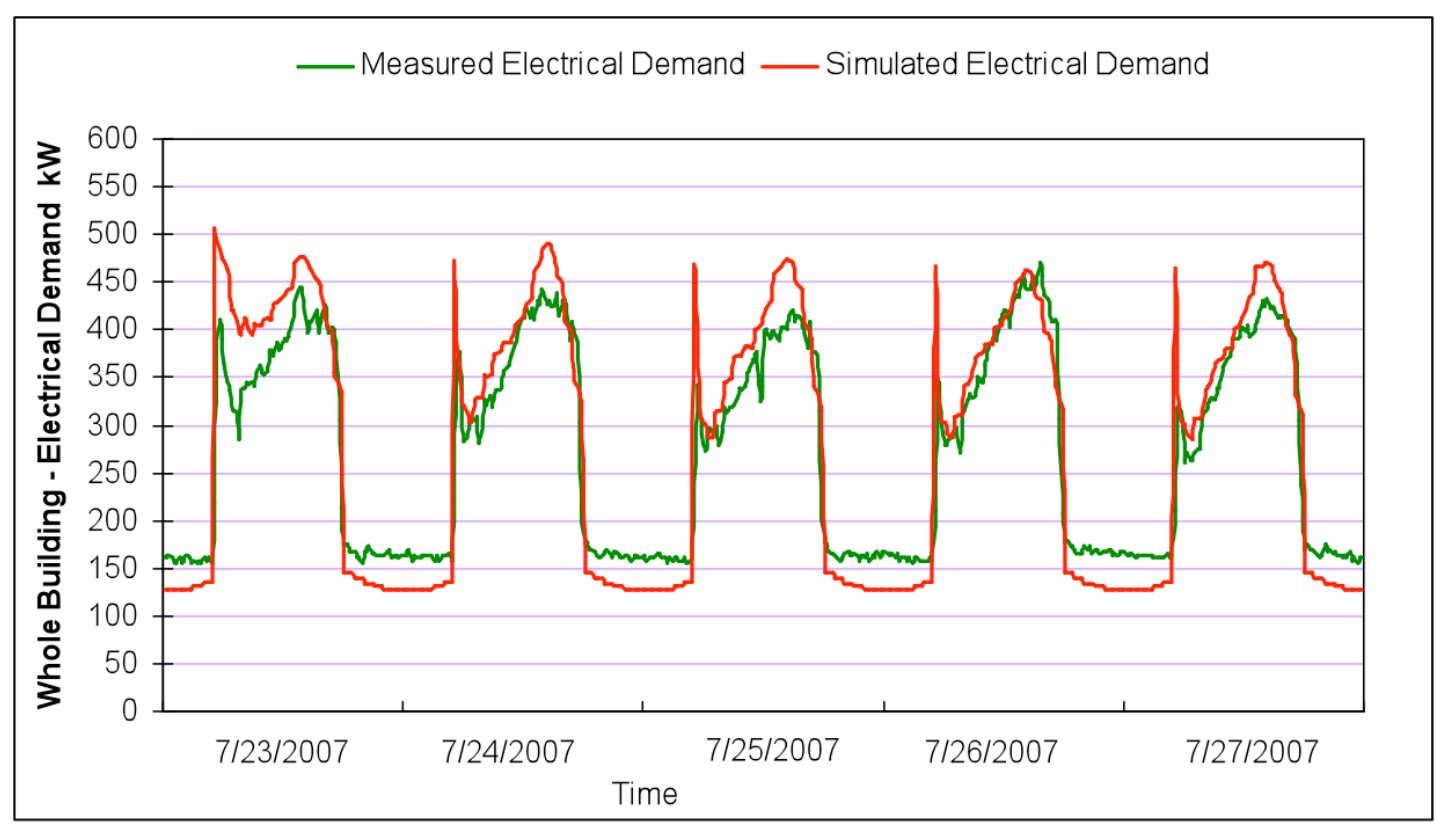

Figure C 33: Daily Electrical Consumption of Simulation Model vs. Actual Electrical Consumption IN JuLY - Two PARKside

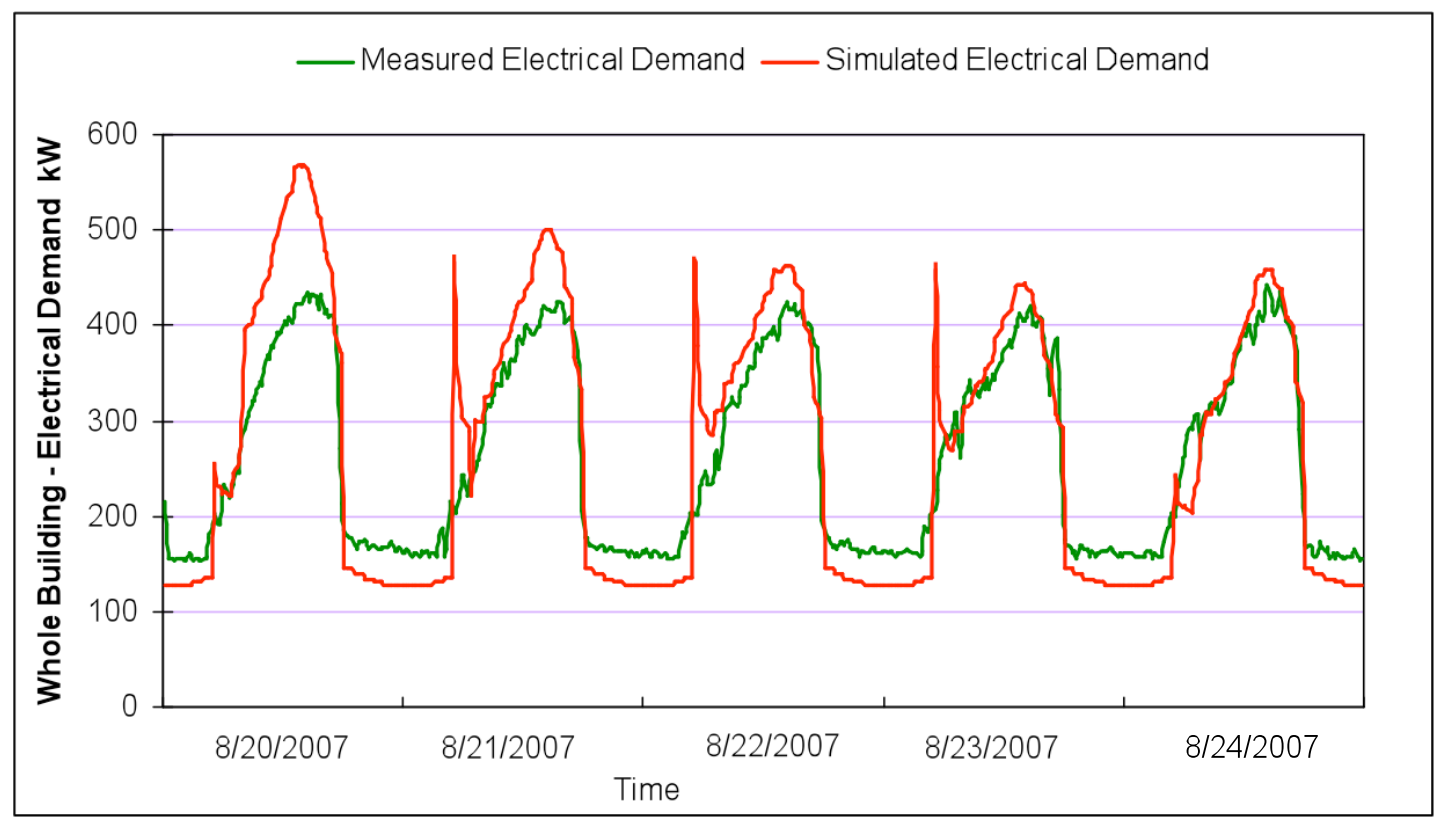

Figure C 34: Daily Electrical Consumption of Simulation Model vs. Actual Electrical Consumption in July - Two Parkside 


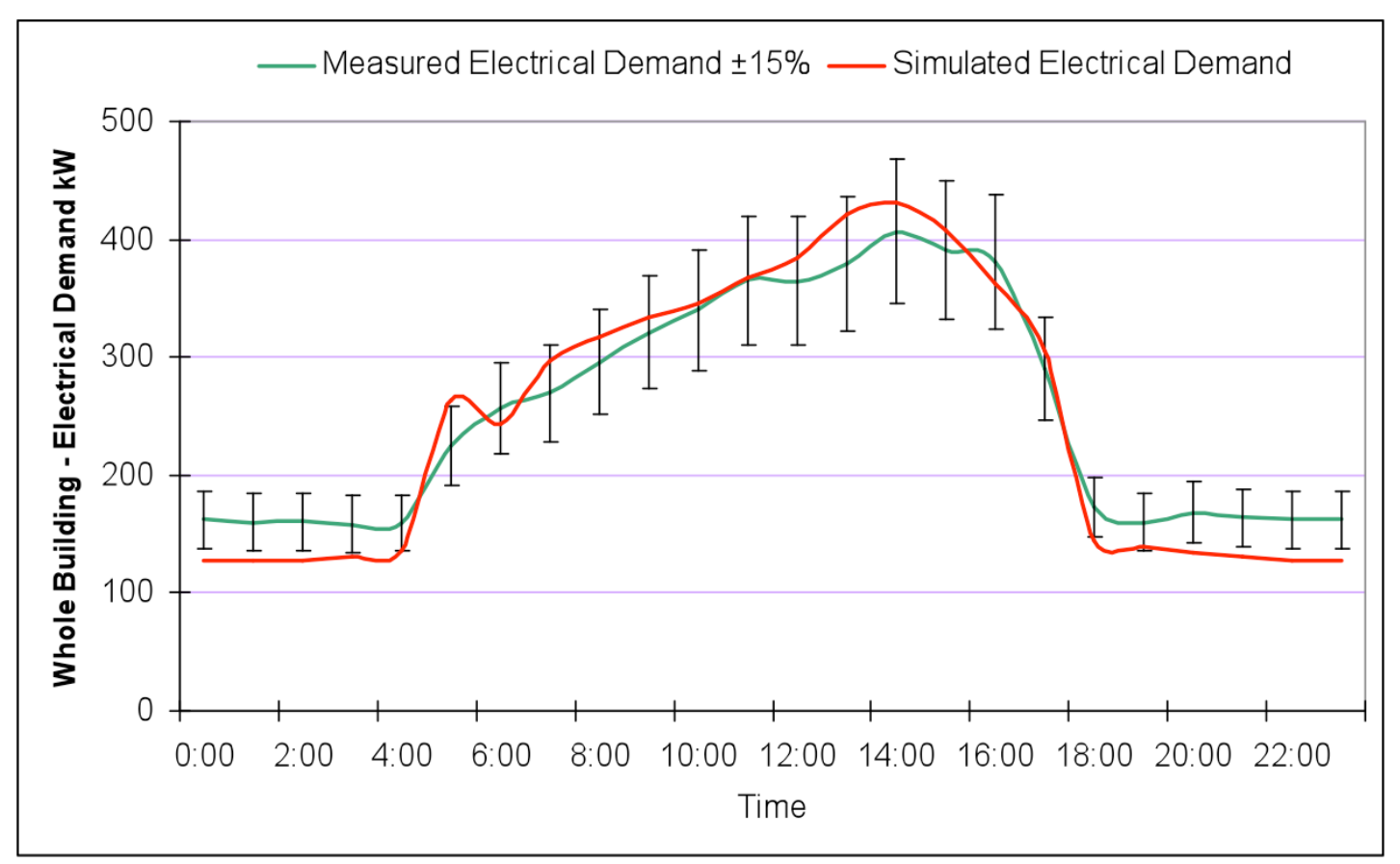

Figure C 35: Hourly Electrical Consumption of Simulation Model vs. Actual Electrical CONSUMPTION ONE daY - TWO PARKSIDE

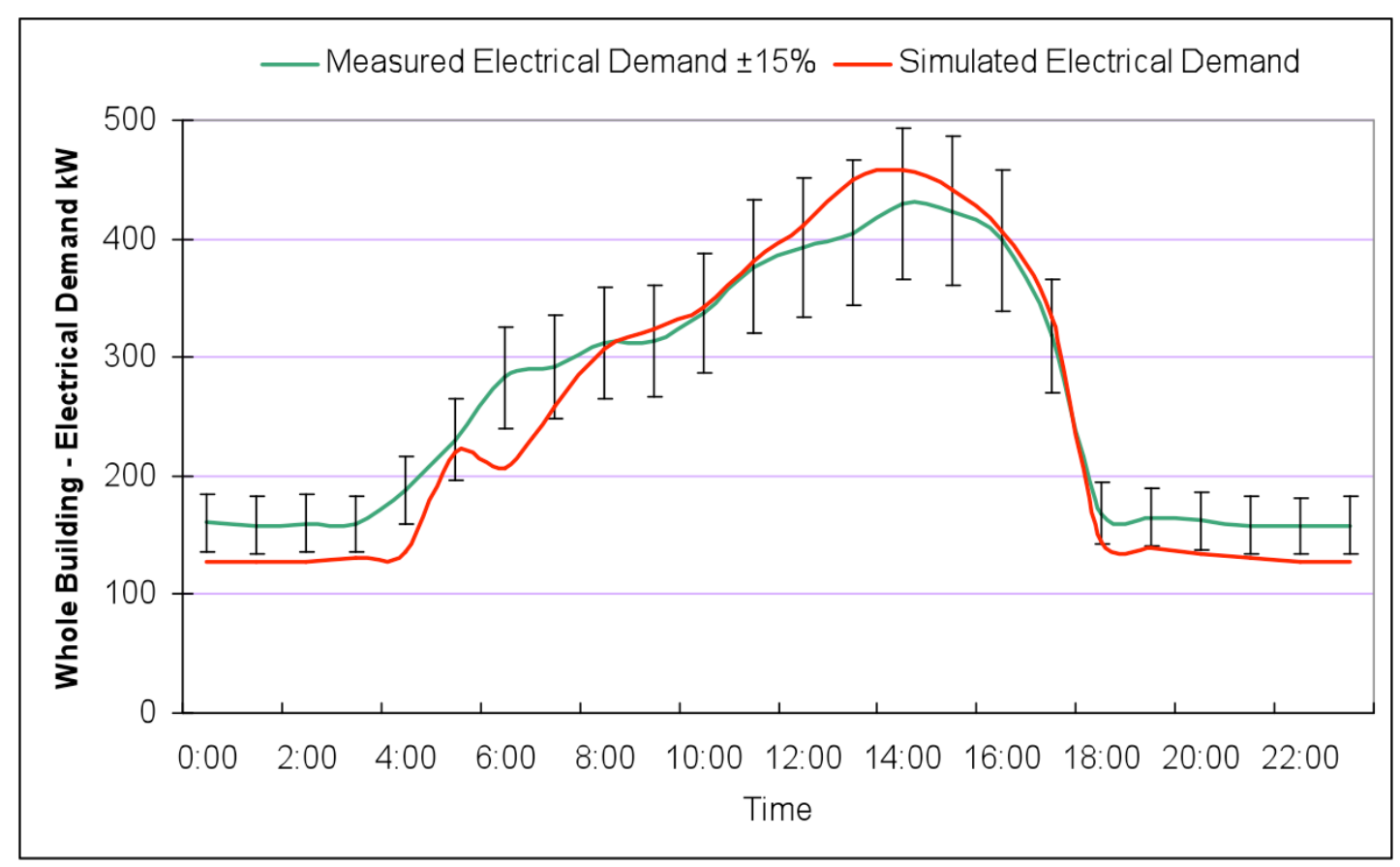

figure C 36: Hourly Electrical Consumption of Simulation Model vs. Actual Electrical Consumption One day - Two Parkside 


\section{VANDERBILTPLAZA}

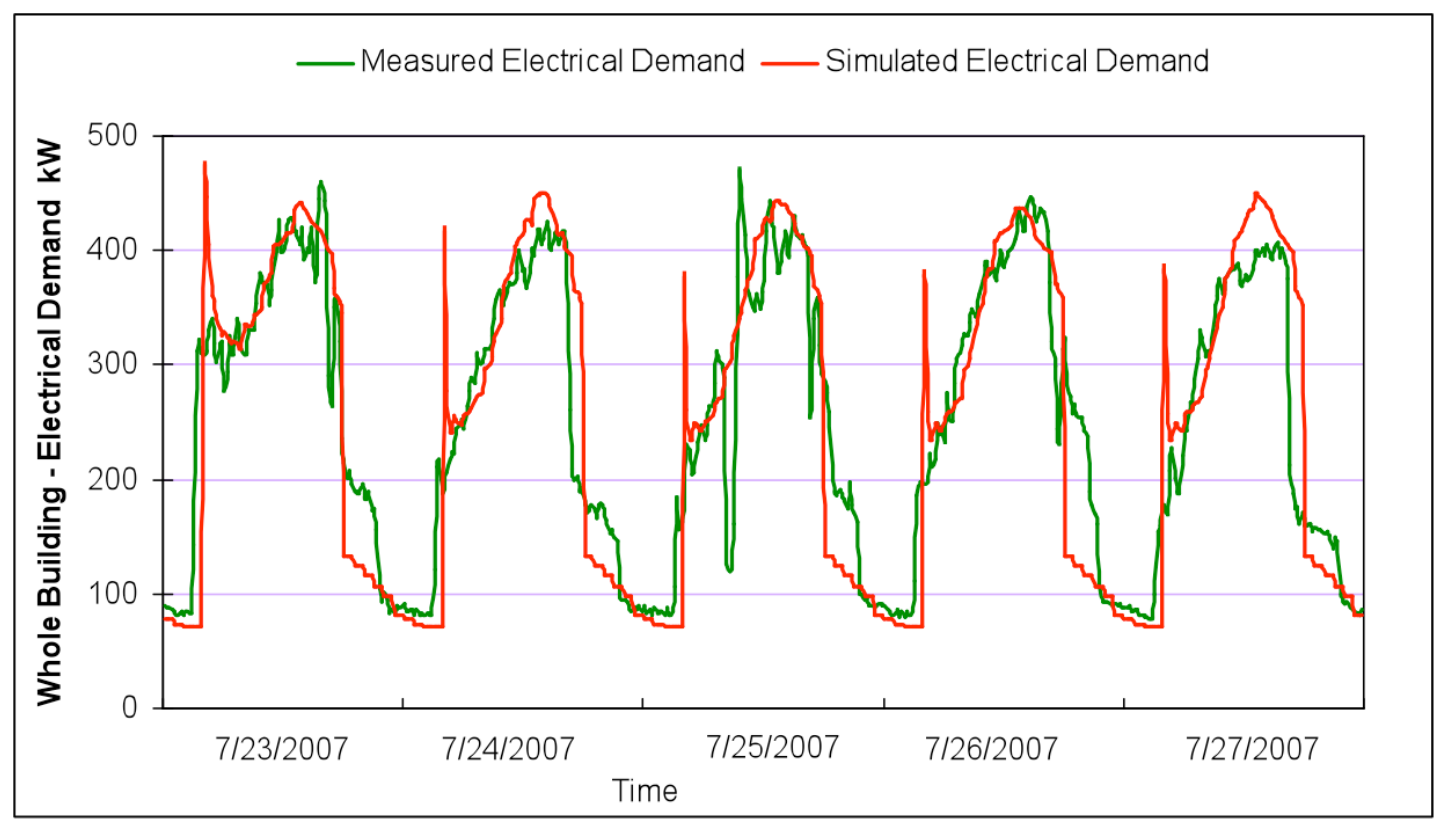

Figure C 37: Daily Electrical Consumption of Simulation Model vs. Actual Electrical CONSUMption IN JULY - TWO PARKside

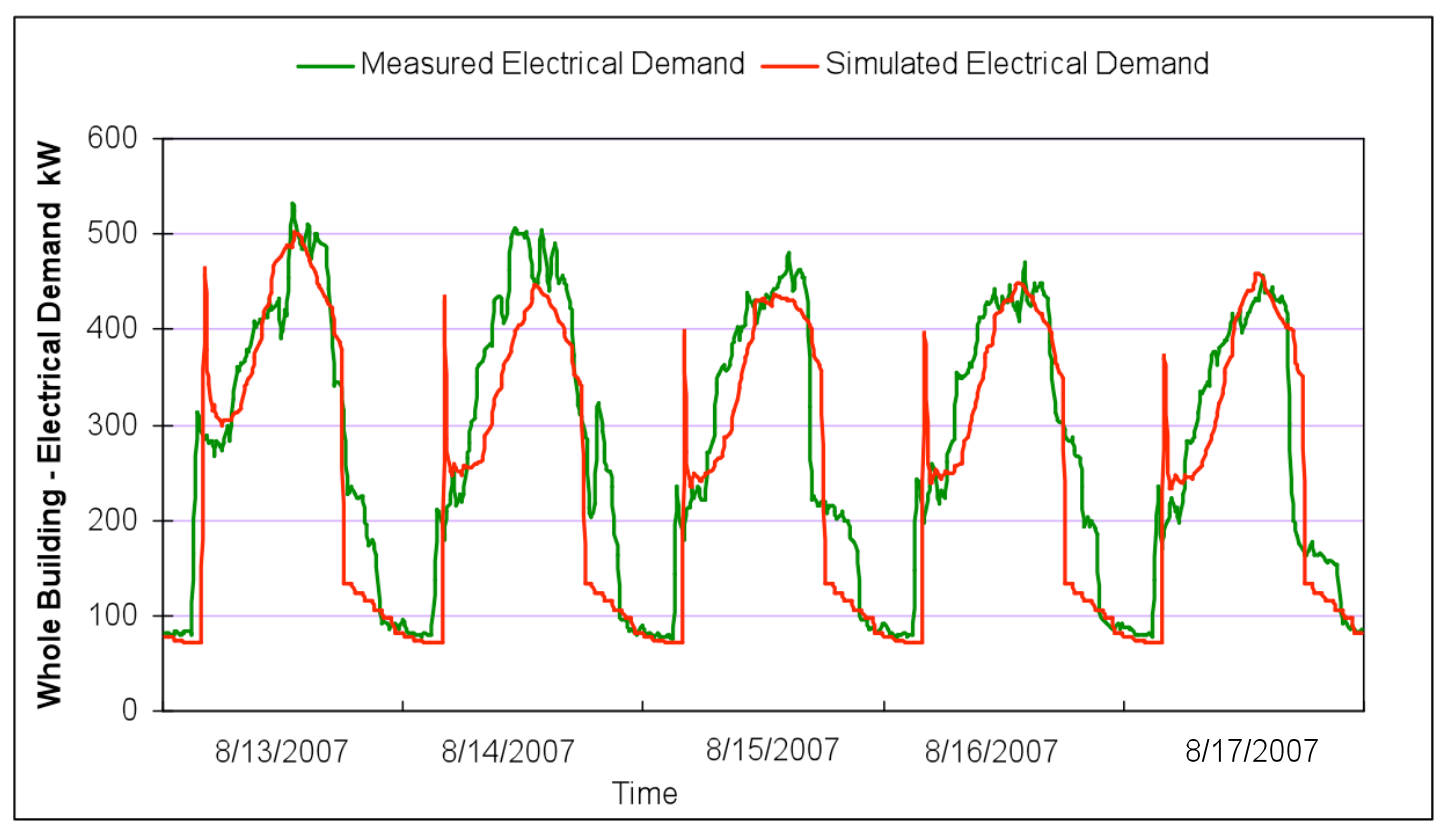

Figure C 38: Daily Electrical Consumption of Simulation Model vs. Actual Electrical Consumption in July - Two Parkside 


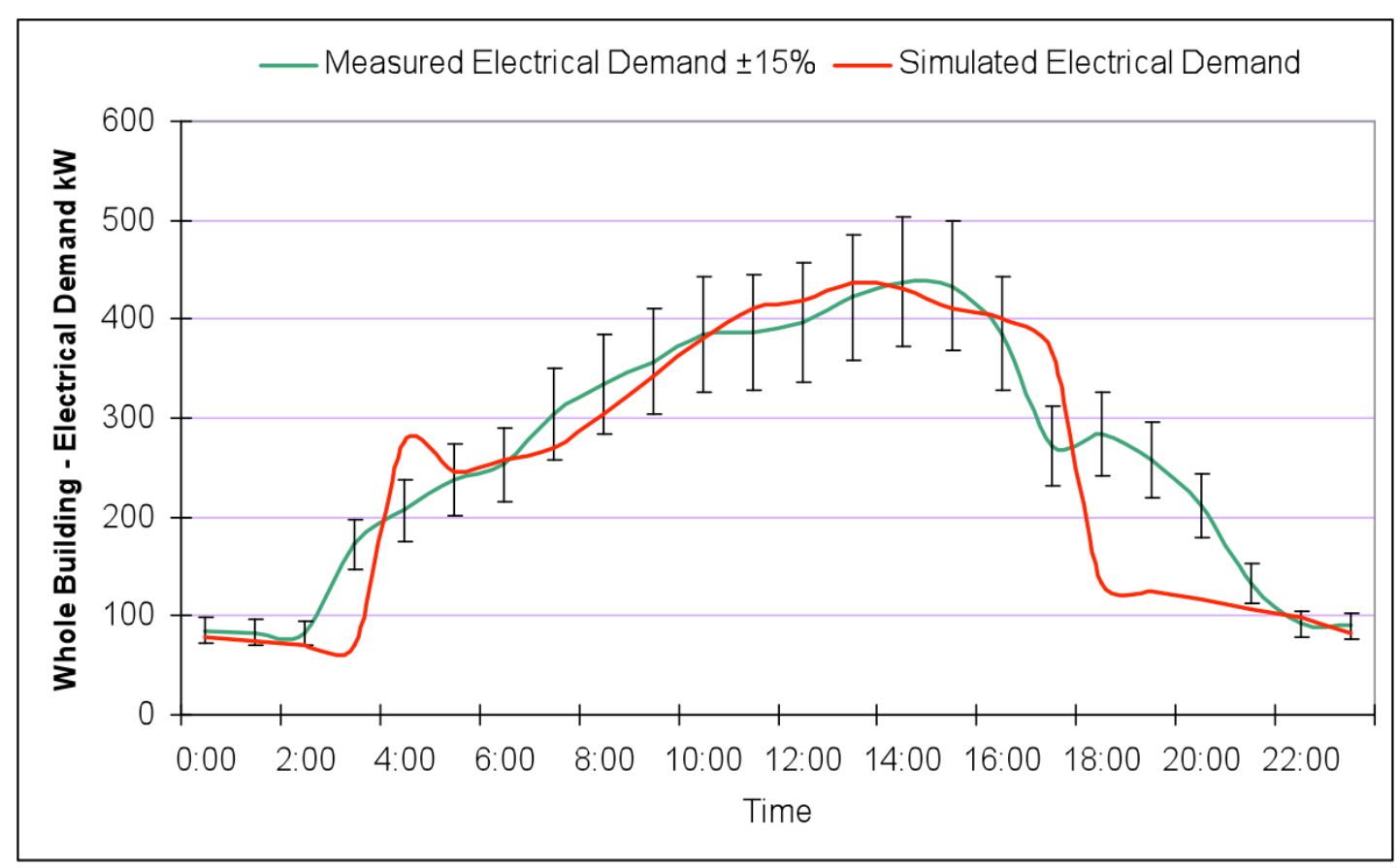

Figure C 39: Hourly Electrical Consumption of Simulation Model vs. Actual Electrical CONSUMPTION ONE daY - TWO PARKSIDE

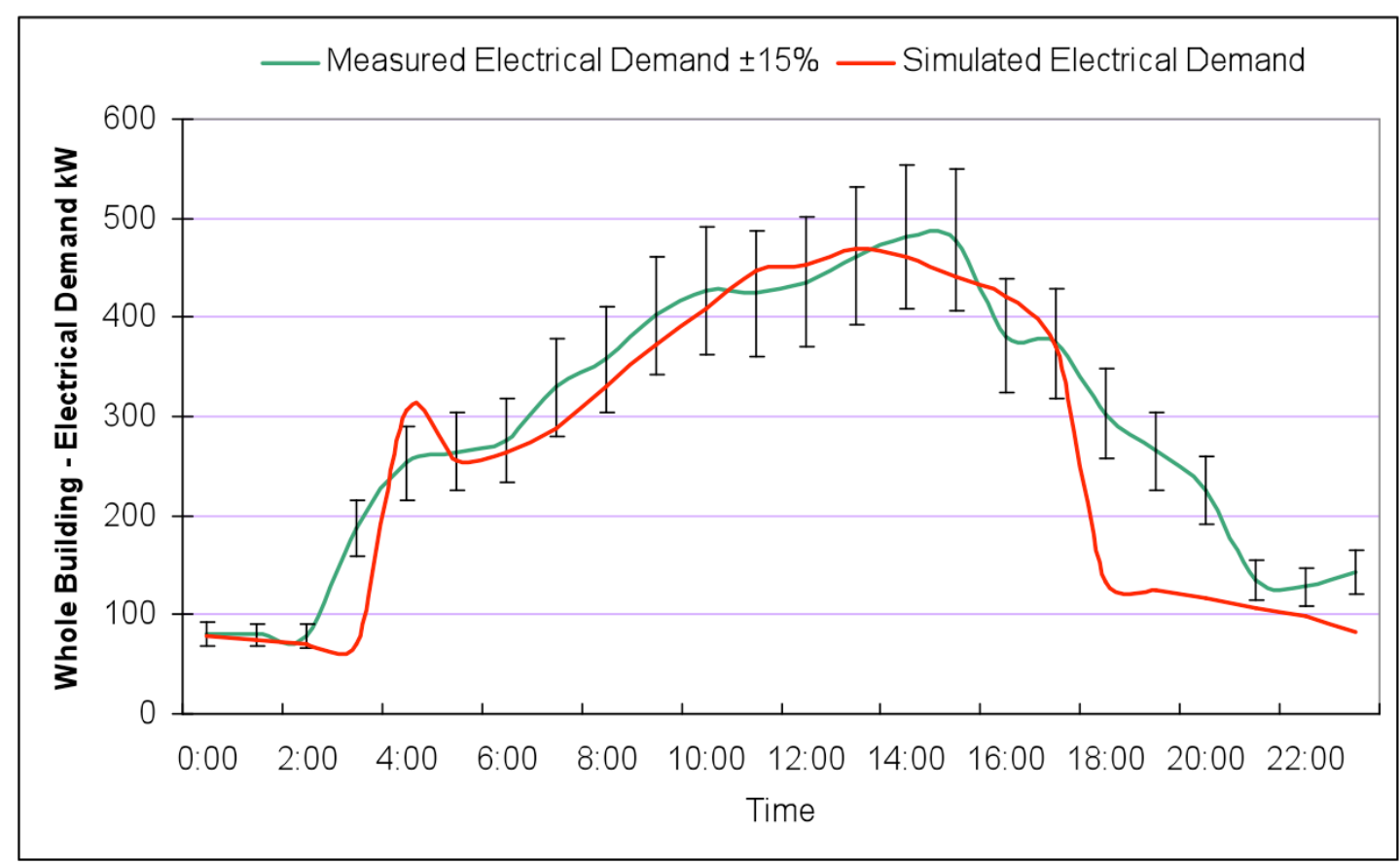

Figure C 40: Hourly Electrical Consumption of Simulation Model vs. Actual Electrical CONSUMPTION ONE dAY - TWO PARKSIDE 


\section{INLAND REgIONAL CENIER}

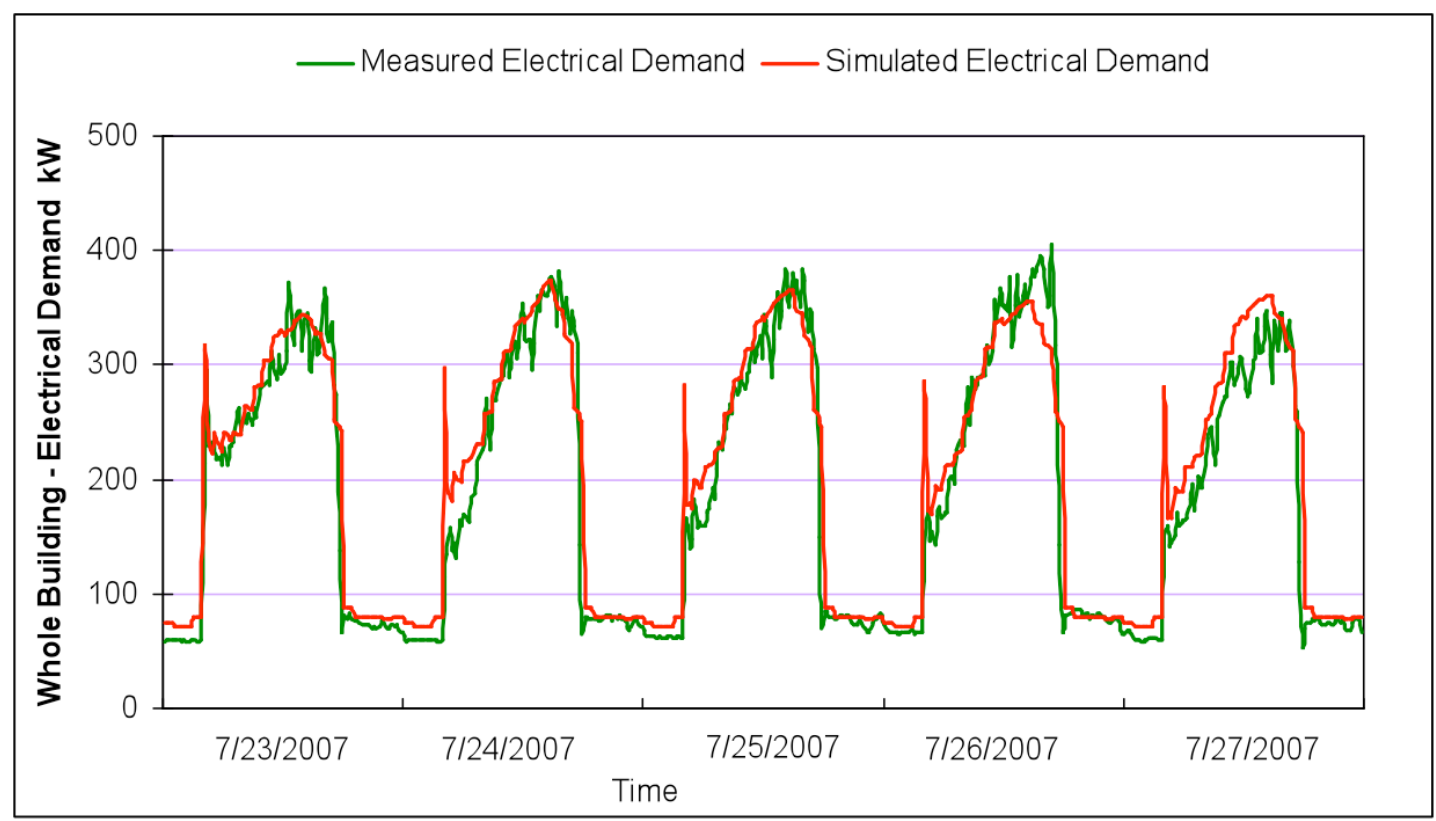

Figure C 41: Daily Electrical Consumption of Simulation Model vs. Actual Electrical CONSUMPTION IN JULY - TWO PARKSIDE

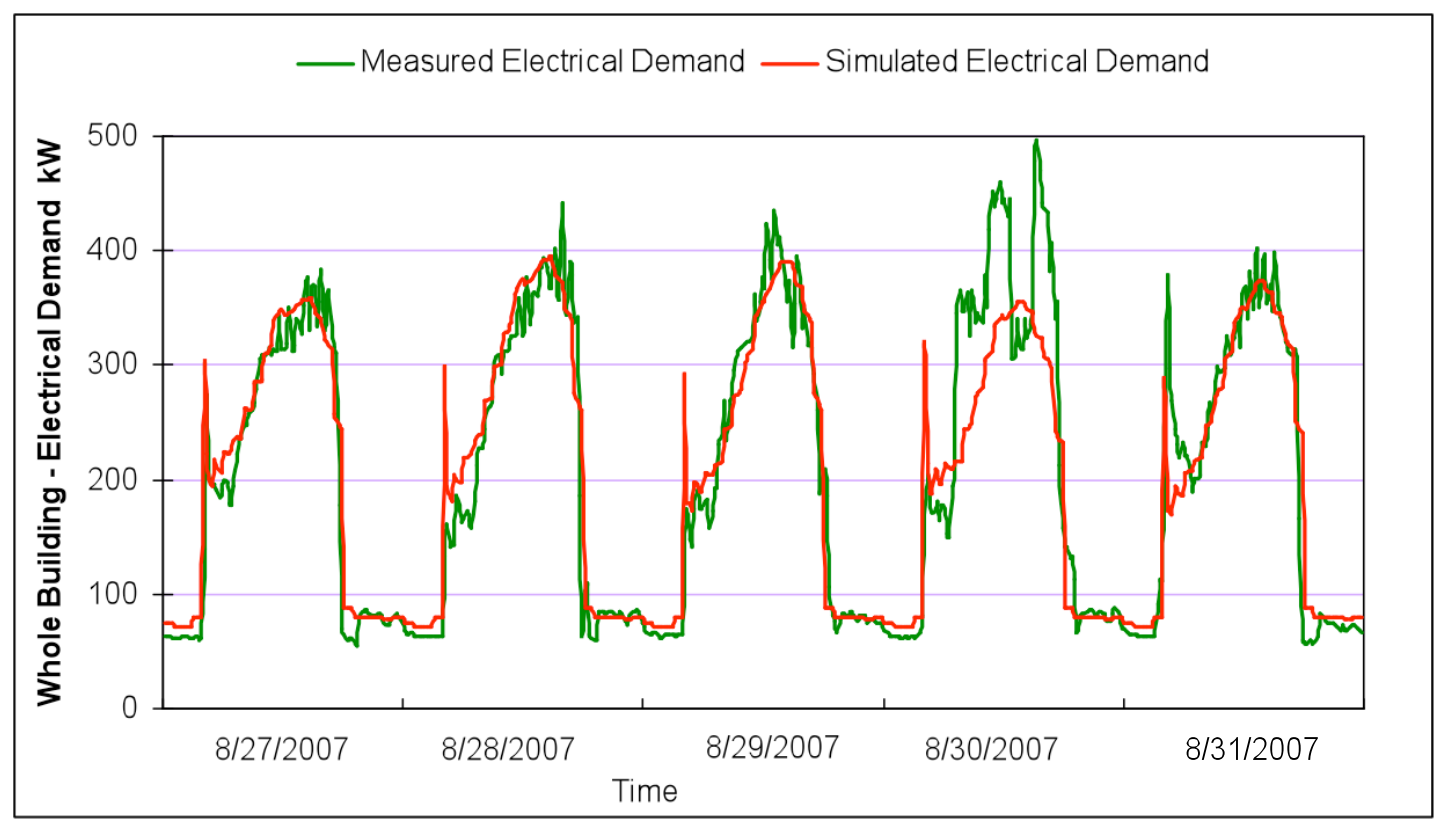

Figure C 42: Daily Electrical Consumption of Simulation Model vs. Actual Electrical Consumption IN July - Two PARKside 


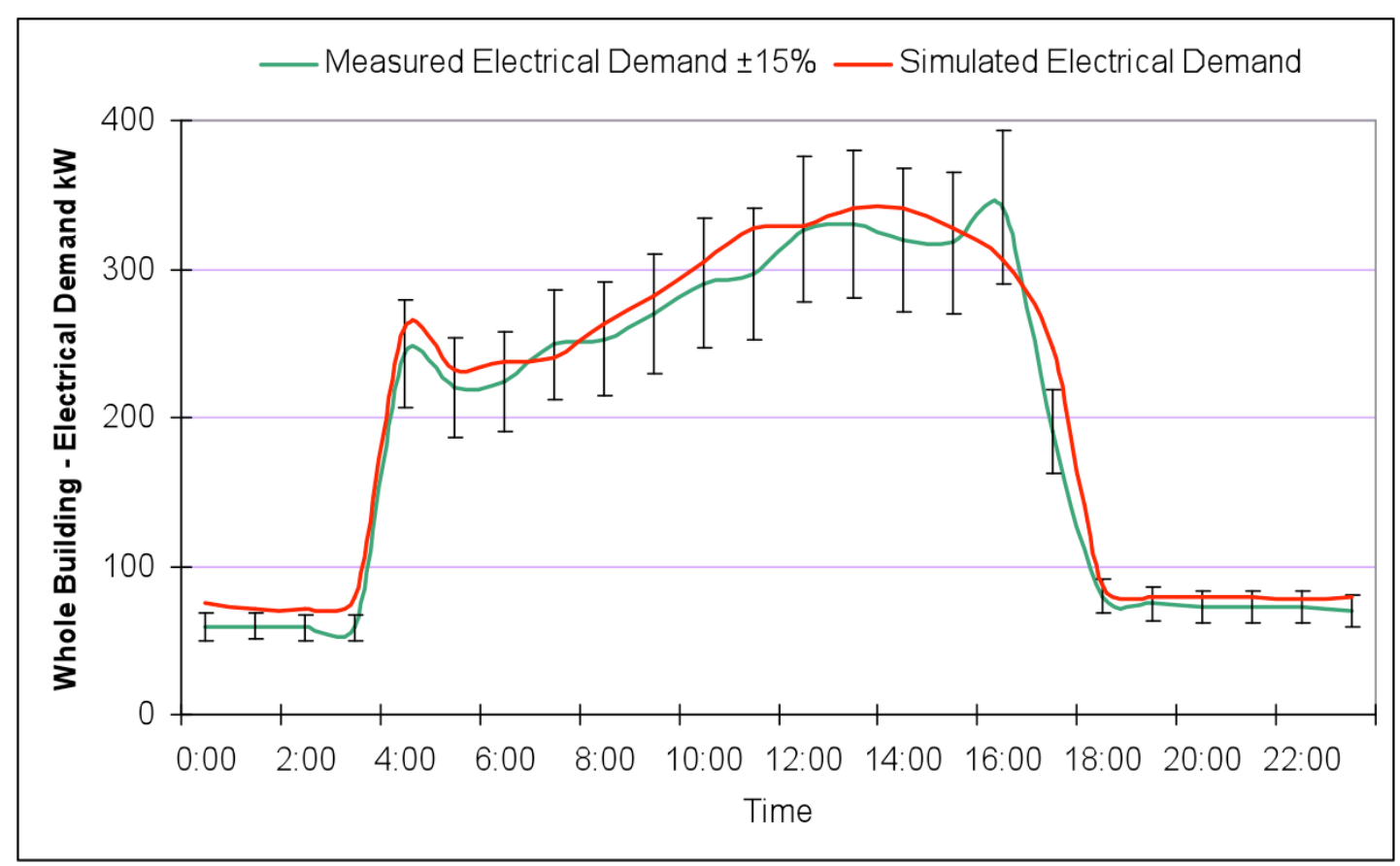

Figure C 43: Hourly Electrical Consumption of Simulation Model vs. Actual Electrical CONSUMPTION ONE daY - TWO PARKSIDE

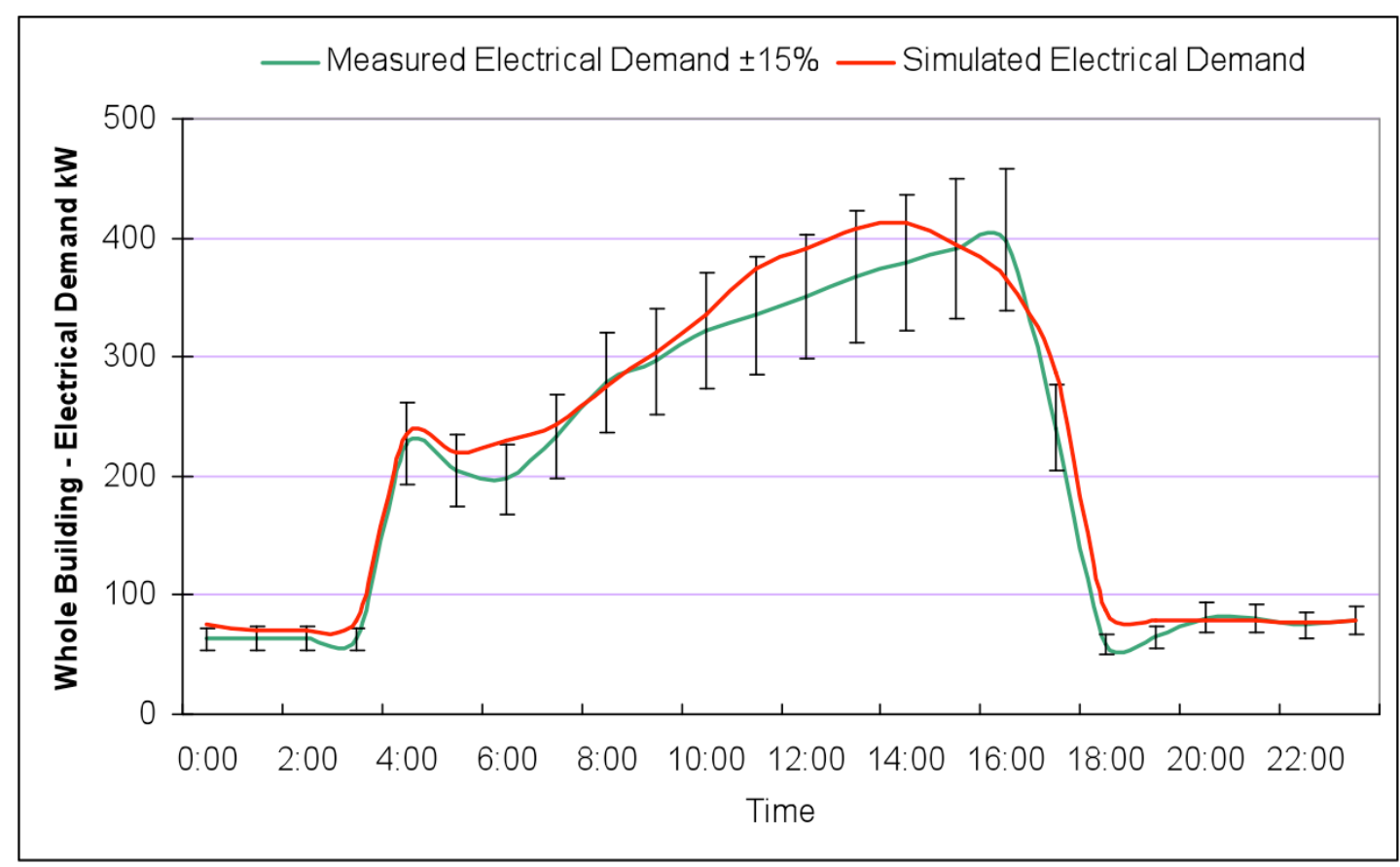

Figure C 44: Hourly Electrical Consumption of Simulation Model vs. Actual Electrical Consumption One day - Two Parkside 


\section{ApPendix D - Fied Results}

\section{ENERG Y ANALYSIS ON AUTO-DR EVENTDAYS}

\section{Table D 1: Demand Shed on Auto-Dr Days - Two Carnegie Plaza}

\begin{tabular}{|c|c|c|c|c|c|c|c|}
\hline \multirow{2}{*}{ DATE } & \multirow{2}{*}{ Period } & \multicolumn{2}{|c|}{$\mathbf{k W}$} & \multicolumn{2}{|c|}{$\mathrm{W} / \mathrm{FT}^{2}$} & \multicolumn{2}{|c|}{ WBP\% } \\
\hline & & Max & Ave & MAX & Ave & MaX & Ave \\
\hline \multirow[t]{2}{*}{ CPP-1 } & Moderate Price ( $12 \mathrm{pm}-3 \mathrm{pm})$ & 45.1 & 18.2 & 0.54 & 0.22 & $15 \%$ & $6 \%$ \\
\hline & High Price ( 3 pm- 6 pm) & 57.6 & -8.2 & 0.69 & -0.10 & $20 \%$ & $-3 \%$ \\
\hline \multirow[t]{2}{*}{ CPP-2 } & Moderate Price ( $12 \mathrm{pm}-3 \mathrm{pm})$ & 42.7 & 12.9 & 0.51 & 0.15 & $15 \%$ & $4 \%$ \\
\hline & High Price ( 3 pm- 6 pm) & 55.2 & 0.8 & 0.66 & 0.01 & $19 \%$ & $0 \%$ \\
\hline \multirow[t]{2}{*}{ CPP-3 } & Moderate Price (12 pm-3 pm) & 19.7 & 9.0 & 0.24 & 0.11 & $7 \%$ & $3 \%$ \\
\hline & High Price ( 3 pm- 6 pm) & 18.7 & -12.4 & 0.22 & -0.15 & $6 \%$ & $-4 \%$ \\
\hline \multirow[t]{2}{*}{ CPP-4 } & Moderate Price ( $12 \mathrm{pm}-3 \mathrm{pm})$ & 30.2 & 19.1 & 0.36 & 0.23 & $12 \%$ & $8 \%$ \\
\hline & High Price ( $3 \mathrm{pm}-6 \mathrm{pm})$ & 30.7 & 17.4 & 0.37 & 0.21 & $13 \%$ & $7 \%$ \\
\hline \multirow[t]{2}{*}{ CPP-5 } & Moderate Price (12 pm-3 pm) & 43.7 & 21.9 & 0.52 & 0.26 & $17 \%$ & $8 \%$ \\
\hline & High Price ( 3 pm- $6 \mathrm{pm})$ & 47.5 & 22.6 & 0.57 & 0.27 & $18 \%$ & $9 \%$ \\
\hline \multirow[t]{2}{*}{ CPP- 6} & Moderate Price ( $12 \mathrm{pm}-3 \mathrm{pm}$ ) & 32.6 & 14.7 & 0.39 & 0.18 & $12 \%$ & $6 \%$ \\
\hline & High Price ( 3 pm- 6 pm) & 46.1 & 16.0 & 0.55 & 0.19 & $17 \%$ & $6 \%$ \\
\hline \multirow[t]{2}{*}{ CPP-7 } & Moderate Price ( $12 \mathrm{pm}-3 \mathrm{pm})$ & 39.8 & 16.0 & 0.48 & 0.19 & $16 \%$ & $7 \%$ \\
\hline & High Price ( 3 pm- 6 pm) & 41.3 & 9.3 & 0.49 & 0.11 & $17 \%$ & $4 \%$ \\
\hline \multirow[t]{2}{*}{ CPP-8 } & Moderate Price ( $12 \mathrm{pm}-3 \mathrm{pm})$ & 43.2 & 21.6 & 0.52 & 0.26 & $18 \%$ & $9 \%$ \\
\hline & High Price ( 3 pm- 6 pm) & 29.3 & 6.6 & 0.35 & 0.08 & $12 \%$ & $3 \%$ \\
\hline \multirow[t]{2}{*}{ CPP-9 } & Moderate Price ( $12 \mathrm{pm}-3 \mathrm{pm}$ ) & 26.9 & 6.9 & 0.32 & 0.08 & $11 \%$ & $3 \%$ \\
\hline & High Price ( 3 pm- 6 pm) & 31.7 & 7.8 & 0.38 & 0.09 & $13 \%$ & $3 \%$ \\
\hline \multirow[t]{2}{*}{ CPP-10 } & Moderate Price (12 pm-3 pm) & 25.4 & 6.1 & 0.30 & 0.07 & $10 \%$ & $2 \%$ \\
\hline & High Price ( 3 pm- $6 \mathrm{pm})$ & 20.2 & 6.0 & 0.24 & 0.07 & $8 \%$ & $2 \%$ \\
\hline \multirow[t]{2}{*}{ CPP-11 } & Moderate Price ( $12 \mathrm{pm}-3 \mathrm{pm})$ & 22.6 & 9.7 & 0.27 & 0.12 & $8 \%$ & $4 \%$ \\
\hline & High Price ( 3 pm- $6 \mathrm{pm})$ & 22.1 & 7.2 & 0.26 & 0.09 & $8 \%$ & $3 \%$ \\
\hline Average & Peak Period ( 12 pm-3 pm) & 33.3 & 13.1 & 0.40 & 0.16 & $13 \%$ & $5 \%$ \\
\hline
\end{tabular}




\section{Table D 2: Demand Shed on Auto-Dr Days - One Carnegie Plaza}

\begin{tabular}{|c|c|c|c|c|c|c|c|}
\hline \multirow{2}{*}{ DATE } & \multirow[t]{2}{*}{ PERIOD } & \multicolumn{2}{|c|}{$\mathbf{k W}$} & \multicolumn{2}{|c|}{$\mathrm{W} / \mathrm{FT}^{2}$} & \multicolumn{2}{|c|}{ WBP\% } \\
\hline & & $\operatorname{MaX}$ & Ave & MAX & Ave & MaX & Ave \\
\hline \multirow[t]{2}{*}{ CPP- 1} & Moderate Price (12 pm-3 pm) & 26.9 & -4.3 & 0.32 & -0.05 & $8 \%$ & $-1 \%$ \\
\hline & High Price ( 3 pm- 6 pm) & 12.5 & -20.1 & 0.15 & -0.24 & $4 \%$ & $-6 \%$ \\
\hline \multirow[t]{2}{*}{ CPP-2 } & Moderate Price (12 pm-3 pm) & -12.5 & -20.9 & -0.15 & -0.25 & $-4 \%$ & $-6 \%$ \\
\hline & High Price ( 3 pm- 6 pm) & 9.6 & -13.2 & 0.11 & -0.16 & $3 \%$ & $-4 \%$ \\
\hline \multirow[t]{2}{*}{ CPP-3 } & Moderate Price (12 pm-3 pm) & 19.2 & -5.3 & 0.23 & -0.06 & $6 \%$ & $-2 \%$ \\
\hline & High Price ( 3 pm- 6 pm) & 35.5 & 7.5 & 0.42 & 0.09 & $10 \%$ & $2 \%$ \\
\hline \multirow[t]{2}{*}{ CPP- 4} & Moderate Price (12 pm-3 pm) & 107.5 & 33.1 & 1.28 & 0.40 & $31 \%$ & $10 \%$ \\
\hline & High Price ( 3 pm- 6 pm) & 34.6 & 14.5 & 0.41 & 0.17 & $10 \%$ & $4 \%$ \\
\hline \multirow[t]{2}{*}{ CPP-5 } & Moderate Price (12 pm-3 pm) & 71.0 & 17.0 & 0.85 & 0.20 & $19 \%$ & $5 \%$ \\
\hline & High Price ( 3 pm- 6 pm) & 49.0 & 11.1 & 0.58 & 0.13 & $13 \%$ & $3 \%$ \\
\hline \multirow[t]{2}{*}{ CPP- 6} & Moderate Price (12 pm-3 pm) & 60.5 & 16.7 & 0.72 & 0.20 & $16 \%$ & $5 \%$ \\
\hline & High Price ( 3 pm-6 pm) & 43.2 & 2.2 & 0.52 & 0.03 & $12 \%$ & $1 \%$ \\
\hline \multirow[t]{2}{*}{ CPP-7 } & Moderate Price ( $12 \mathrm{pm}-3 \mathrm{pm})$ & 90.2 & 41.8 & 1.08 & 0.50 & $25 \%$ & $11 \%$ \\
\hline & High Price ( 3 pm-6 pm) & 75.8 & 32.8 & 0.91 & 0.39 & $21 \%$ & $9 \%$ \\
\hline \multirow[t]{2}{*}{ CPP-8 } & Moderate Price (12 pm-3 pm) & 65.3 & 29.3 & 0.78 & 0.35 & $18 \%$ & $8 \%$ \\
\hline & High Price ( 3 pm-6 pm) & 43.2 & 18.9 & 0.52 & 0.23 & $12 \%$ & $5 \%$ \\
\hline \multirow[t]{2}{*}{ CPP-9 } & Moderate Price ( 12 pm-3 pm) & 46.1 & 22.3 & 0.55 & 0.27 & $13 \%$ & $6 \%$ \\
\hline & High Price ( 3 pm- 6 pm) & 73.9 & 14.0 & 0.88 & 0.17 & $20 \%$ & $4 \%$ \\
\hline \multirow[t]{2}{*}{ CPP- 10} & Moderate Price (12 pm-3 pm) & 68.2 & 13.4 & 0.81 & 0.16 & $19 \%$ & $4 \%$ \\
\hline & High Price ( 3 pm-6 pm) & 71.0 & 7.6 & 0.85 & 0.09 & $19 \%$ & $2 \%$ \\
\hline \multirow[t]{2}{*}{ CPP-11 } & Moderate Price ( 12 pm-3 pm) & 67.2 & 25.4 & 0.80 & 0.30 & $18 \%$ & $7 \%$ \\
\hline & High Price ( 3 pm-6 pm) & 51.8 & 13.0 & 0.62 & 0.16 & $14 \%$ & $4 \%$ \\
\hline Average & Peak Period ( 12 pm-3 pm) & 63.7 & 19.6 & 0.76 & 0.23 & $17 \%$ & $5 \%$ \\
\hline
\end{tabular}




\section{Table D 3: Demand Shed on Auto-dr Days - One Carnegie Plaza (smaller building)}

\begin{tabular}{|c|c|c|c|c|c|c|c|}
\hline \multirow{2}{*}{ DATE } & \multirow[t]{2}{*}{ Period } & \multicolumn{2}{|c|}{$\mathbf{k W}$} & \multicolumn{2}{|c|}{$\mathrm{W} / \mathrm{FT}^{2}$} & \multicolumn{2}{|c|}{ WBP\% } \\
\hline & & MAX & Ave & Max & Ave & MAX & Ave \\
\hline \multirow[t]{2}{*}{ CPP-1 } & Moderate Price ( $12 \mathrm{pm}-3 \mathrm{pm})$ & 34.6 & 3.5 & 0.41 & 0.04 & $18 \%$ & $2 \%$ \\
\hline & High Price ( 3 pm- 6 pm) & 33.6 & 1.6 & 0.40 & 0.02 & $18 \%$ & $1 \%$ \\
\hline \multirow[t]{2}{*}{ CPP-2 } & Moderate Price (12 pm-3 pm) & 35.5 & -13.7 & 0.42 & -0.16 & $19 \%$ & $-7 \%$ \\
\hline & High Price ( 3 pm- 6 pm) & 11.5 & -1.5 & 0.14 & -0.02 & $6 \%$ & $-1 \%$ \\
\hline \multirow[t]{2}{*}{ CPP-3 } & Moderate Price (12 pm-3 pm) & 32.6 & -8.4 & 0.39 & -0.10 & $17 \%$ & $-4 \%$ \\
\hline & High Price ( 3 pm-6 pm) & 16.3 & -2.6 & 0.19 & -0.03 & $9 \%$ & $-1 \%$ \\
\hline \multirow[t]{2}{*}{ CPP-4 } & Moderate Price ( $12 \mathrm{pm}-3 \mathrm{pm})$ & 123.8 & 50.6 & 1.48 & 0.60 & $59 \%$ & $24 \%$ \\
\hline & High Price ( 3 pm-6 pm) & 99.8 & 26.6 & 1.19 & 0.32 & $47 \%$ & $13 \%$ \\
\hline \multirow[t]{2}{*}{ CPP-5 } & Moderate Price ( $12 \mathrm{pm}-3 \mathrm{pm})$ & 34.6 & 18.1 & 0.41 & 0.22 & $16 \%$ & $8 \%$ \\
\hline & High Price ( 3 pm- 6 pm) & 107.5 & 26.2 & 1.28 & 0.31 & $49 \%$ & $12 \%$ \\
\hline \multirow[t]{2}{*}{ CPP-6 } & Moderate Price ( $12 \mathrm{pm}-3 \mathrm{pm})$ & 42.2 & 11.8 & 0.50 & 0.14 & $19 \%$ & $5 \%$ \\
\hline & High Price ( 3 pm- 6 pm) & 67.2 & 24.6 & 0.80 & 0.29 & $30 \%$ & $11 \%$ \\
\hline \multirow[t]{2}{*}{ CPP-7 } & Moderate Price (12 pm-3 pm) & 50.9 & 28.4 & 0.61 & 0.34 & $26 \%$ & $14 \%$ \\
\hline & High Price ( 3 pm- 6 pm) & 48.0 & 20.3 & 0.57 & 0.24 & $24 \%$ & $10 \%$ \\
\hline \multirow[t]{2}{*}{ CPP-8 } & Moderate Price (12 pm-3 pm) & 77.8 & 39.6 & 0.93 & 0.47 & $40 \%$ & $20 \%$ \\
\hline & High Price ( 3 pm- 6 pm) & 36.5 & 15.8 & 0.44 & 0.19 & $19 \%$ & $8 \%$ \\
\hline \multirow[t]{2}{*}{ CPP-9 } & Moderate Price ( $12 \mathrm{pm}-3 \mathrm{pm})$ & 36.5 & 1.3 & 0.44 & 0.02 & $20 \%$ & $1 \%$ \\
\hline & High Price ( 3 pm- 6 pm) & 16.3 & -10.1 & 0.19 & -0.12 & $9 \%$ & $-6 \%$ \\
\hline \multirow[t]{2}{*}{ CPP- 10} & Moderate Price ( $12 \mathrm{pm}-3 \mathrm{pm})$ & 16.3 & -9.1 & 0.19 & -0.11 & $9 \%$ & $-5 \%$ \\
\hline & High Price ( 3 pm- 6 pm) & 35.5 & -0.4 & 0.42 & 0.00 & $20 \%$ & $0 \%$ \\
\hline \multirow[t]{2}{*}{ CPP-11 } & Moderate Price ( $12 \mathrm{pm}-3 \mathrm{pm})$ & 39.4 & 10.1 & 0.47 & 0.12 & $20 \%$ & $5 \%$ \\
\hline & High Price ( 3 pm- 6 pm) & 24.0 & -1.7 & 0.29 & -0.02 & $12 \%$ & $-1 \%$ \\
\hline Average & Peak Period (12 pm-3 pm) & 53.5 & 15.8 & 0.64 & 0.19 & $26 \%$ & $8 \%$ \\
\hline
\end{tabular}




\section{Table D 4: Demand Shed on Auto-DR Days - One Vanderbilt}

\begin{tabular}{|c|c|c|c|c|c|c|c|}
\hline \multirow[t]{2}{*}{ DATE } & \multirow[t]{2}{*}{ Period } & \multicolumn{2}{|c|}{$\mathbf{k W}$} & \multicolumn{2}{|c|}{$\mathbf{W} / \mathrm{FT}^{2}$} & \multicolumn{2}{|c|}{ WBP\% } \\
\hline & & MAX & AVE & MAX & AVE & MAX & AVE \\
\hline \multirow[t]{2}{*}{ CPP-1 } & Moderate Price (12 pm-3 pm) & 19.2 & 5.8 & 0.23 & 0.07 & $5 \%$ & $1 \%$ \\
\hline & High Price ( 3 pm- 6 pm) & 4.8 & -17.1 & 0.06 & -0.20 & $1 \%$ & $-4 \%$ \\
\hline \multirow[t]{2}{*}{ CPP-2 } & Moderate Price (12 pm-3 pm) & 16.3 & 2.8 & 0.19 & 0.03 & $4 \%$ & $1 \%$ \\
\hline & High Price ( 3 pm-6 pm) & 10.6 & -14.9 & 0.13 & -0.18 & $3 \%$ & $-4 \%$ \\
\hline \multirow[t]{2}{*}{ CPP-3 } & Moderate Price ( $12 \mathrm{pm}-3 \mathrm{pm})$ & 7.7 & -0.5 & 0.09 & -0.01 & $2 \%$ & $0 \%$ \\
\hline & High Price ( 3 pm-6 pm) & 2.9 & -3.8 & 0.03 & -0.05 & $1 \%$ & $-1 \%$ \\
\hline \multirow[t]{2}{*}{ CPP- 4} & Moderate Price (12 pm-3 pm) & 84.5 & 45.1 & 1.01 & 0.54 & $19 \%$ & $10 \%$ \\
\hline & High Price ( 3 pm-6 pm) & 34.6 & 12.8 & 0.41 & 0.15 & $8 \%$ & $3 \%$ \\
\hline \multirow[t]{2}{*}{ CPP-5 } & Moderate Price (12 pm-3 pm) & 18.2 & 7.0 & 0.22 & 0.08 & $4 \%$ & $2 \%$ \\
\hline & High Price ( 3 pm-6 pm) & 27.8 & 20.6 & 0.33 & 0.25 & $6 \%$ & $5 \%$ \\
\hline \multirow[t]{2}{*}{ CPP-6 } & Moderate Price ( 12 pm-3 pm) & 11.5 & 7.3 & 0.14 & 0.09 & $3 \%$ & $2 \%$ \\
\hline & High Price ( 3 pm-6 pm) & 22.1 & 13.5 & 0.26 & 0.16 & $5 \%$ & $3 \%$ \\
\hline \multirow[t]{2}{*}{ CPP-7 } & Moderate Price ( $12 \mathrm{pm}-3 \mathrm{pm})$ & 14.4 & 0.1 & 0.17 & 0.00 & $3 \%$ & $0 \%$ \\
\hline & High Price ( 3 pm-6 pm) & 65.3 & 15.1 & 0.78 & 0.18 & $15 \%$ & $4 \%$ \\
\hline \multirow[t]{2}{*}{ CPP-8 } & Moderate Price ( $12 \mathrm{pm}-3 \mathrm{pm})$ & 23.0 & 13.5 & 0.28 & 0.16 & $5 \%$ & $3 \%$ \\
\hline & High Price ( 3 pm-6 pm) & 10.6 & 2.1 & 0.13 & 0.02 & $2 \%$ & $0 \%$ \\
\hline \multirow[t]{2}{*}{ CPP-9 } & Moderate Price ( 12 pm-3 pm) & 28.8 & 22.2 & 0.34 & 0.27 & $7 \%$ & $5 \%$ \\
\hline & High Price ( 3 pm-6 pm) & 80.6 & 53.9 & 0.96 & 0.64 & $19 \%$ & $13 \%$ \\
\hline \multirow[t]{2}{*}{ CPP- 10} & Moderate Price (12 pm-3 pm) & 34.6 & 27.0 & 0.41 & 0.32 & $8 \%$ & $6 \%$ \\
\hline & High Price ( 3 pm-6 pm) & 28.8 & 20.3 & 0.34 & 0.24 & $7 \%$ & $5 \%$ \\
\hline \multirow[t]{2}{*}{ CPP-11 } & Moderate Price ( $12 \mathrm{pm}-3 \mathrm{pm})$ & 8.6 & 1.7 & 0.10 & 0.02 & $2 \%$ & $0 \%$ \\
\hline & High Price ( 3 pm-6 pm) & 2.9 & -0.7 & 0.03 & -0.01 & $1 \%$ & $0 \%$ \\
\hline Average & Peak Period (12 pm-3 pm) & 31.0 & 16.4 & 0.37 & 0.20 & $7 \%$ & $4 \%$ \\
\hline
\end{tabular}




\section{Table D 5: Demand Shed on Auto-DR Days - One Parkside}

\begin{tabular}{|c|c|c|c|c|c|c|c|}
\hline \multirow{2}{*}{ DATE } & \multirow[t]{2}{*}{ PERIOD } & \multicolumn{2}{|c|}{$\mathbf{k W}$} & \multicolumn{2}{|c|}{$\mathbf{W} / \mathrm{FT}^{2}$} & \multicolumn{2}{|c|}{ WBP\% } \\
\hline & & MAX & AVE & MaX & Ave & MAX & AVE \\
\hline \multirow[t]{2}{*}{ CPP-1 } & Moderate Price (12 pm-3 pm) & 16.3 & -2.8 & 0.19 & -0.03 & $5 \%$ & $-1 \%$ \\
\hline & High Price ( 3 pm-6 pm) & 4.8 & -10.6 & 0.06 & -0.13 & $2 \%$ & $-3 \%$ \\
\hline \multirow[t]{2}{*}{ CPP-2 } & Moderate Price (12 pm-3 pm) & 1.0 & -17.4 & 0.01 & -0.21 & $0 \%$ & $-5 \%$ \\
\hline & High Price ( 3 pm-6 pm) & 19.2 & -8.1 & 0.23 & -0.10 & $6 \%$ & $-3 \%$ \\
\hline \multirow[t]{2}{*}{ CPP-3 } & Moderate Price ( $12 \mathrm{pm}-3 \mathrm{pm}$ ) & 19.2 & -5.8 & 0.23 & -0.07 & $6 \%$ & $-2 \%$ \\
\hline & High Price ( 3 pm-6 pm) & 7.7 & -4.1 & 0.09 & -0.05 & $2 \%$ & $-1 \%$ \\
\hline \multirow[t]{2}{*}{ CPP-4 } & Moderate Price (12 pm-3 pm) & 30.7 & -0.1 & 0.37 & 0.00 & $10 \%$ & $0 \%$ \\
\hline & High Price ( 3 pm- 6 pm) & 19.2 & 0.4 & 0.23 & 0.00 & $6 \%$ & $0 \%$ \\
\hline \multirow[t]{2}{*}{ CPP-5 } & Moderate Price (12 pm-3 pm) & 29.8 & 17.0 & 0.36 & 0.20 & $9 \%$ & $5 \%$ \\
\hline & High Price ( 3 pm-6 pm) & 75.8 & 25.2 & 0.91 & 0.30 & $22 \%$ & $7 \%$ \\
\hline \multirow[t]{2}{*}{ CPP-6 } & Moderate Price ( $12 \mathrm{pm}-3 \mathrm{pm}$ ) & 54.7 & 27.4 & 0.65 & 0.33 & $16 \%$ & $8 \%$ \\
\hline & High Price ( 3 pm-6 pm) & 52.8 & 12.3 & 0.63 & 0.15 & $15 \%$ & $4 \%$ \\
\hline \multirow[t]{2}{*}{ CPP-7 } & Moderate Price ( $12 \mathrm{pm}-3 \mathrm{pm}$ ) & 77.8 & 39.9 & 0.93 & 0.48 & $24 \%$ & $12 \%$ \\
\hline & High Price ( 3 pm-6 pm) & 54.7 & 23.9 & 0.65 & 0.29 & $17 \%$ & $7 \%$ \\
\hline \multirow[t]{2}{*}{ CPP-8 } & Moderate Price (12 pm-3 pm) & 52.8 & 34.2 & 0.63 & 0.41 & $16 \%$ & $11 \%$ \\
\hline & High Price ( 3 pm-6 pm) & 61.4 & 20.7 & 0.73 & 0.25 & $19 \%$ & $6 \%$ \\
\hline \multirow[t]{2}{*}{ CPP-9 } & Moderate Price ( 12 pm-3 pm) & 92.2 & 35.3 & 1.10 & 0.42 & $28 \%$ & $11 \%$ \\
\hline & High Price ( 3 pm-6 pm) & 60.5 & 29.6 & 0.72 & 0.35 & $18 \%$ & $9 \%$ \\
\hline \multirow[t]{2}{*}{ CPP- 10} & Moderate Price (12 pm-3 pm) & 51.8 & 32.9 & 0.62 & 0.39 & $16 \%$ & $10 \%$ \\
\hline & High Price ( 3 pm-6 pm) & 41.3 & 15.7 & 0.49 & 0.19 & $12 \%$ & $5 \%$ \\
\hline \multirow[t]{2}{*}{ CPP-11 } & Moderate Price ( 12 pm-3 pm) & 41.3 & 22.6 & 0.49 & 0.27 & $12 \%$ & $7 \%$ \\
\hline & High Price ( 3 pm- 6 pm) & 45.1 & 19.8 & 0.54 & 0.24 & $13 \%$ & $6 \%$ \\
\hline Average & Peak Period (12 pm-3 pm) & 52.6 & 22.3 & 0.63 & 0.27 & $16 \%$ & $7 \%$ \\
\hline
\end{tabular}




\section{Table D 6: Demand Shed on Auto-DR Days - Lakeside Tower}

\begin{tabular}{|c|c|c|c|c|c|c|c|}
\hline \multirow{2}{*}{ DATE } & \multirow{2}{*}{ PERIOD } & \multicolumn{2}{|c|}{$\mathbf{k W}$} & \multicolumn{2}{|c|}{$\mathrm{W} / \mathrm{FT}^{2}$} & \multicolumn{2}{|c|}{ WBP\% } \\
\hline & & MAX & Ave & MAX & Ave & MaX & Ave \\
\hline \multirow[t]{2}{*}{ CPP-1 } & Moderate Price (12 pm-3 pm) & 65.3 & 1.4 & 0.78 & 0.02 & $14 \%$ & $0 \%$ \\
\hline & High Price ( 3 pm- 6 pm) & 134.4 & 16.3 & 1.61 & 0.19 & $28 \%$ & $3 \%$ \\
\hline \multirow[t]{2}{*}{ CPP-2 } & Moderate Price (12 pm-3 pm) & 58.6 & -11.4 & 0.70 & -0.14 & $12 \%$ & $-2 \%$ \\
\hline & High Price ( 3 pm- 6 pm) & 168.0 & 24.6 & 2.01 & 0.29 & $35 \%$ & $5 \%$ \\
\hline \multirow[t]{2}{*}{ CPP-3 } & Moderate Price (12 pm-3 pm) & 24.0 & -6.1 & 0.29 & -0.07 & $5 \%$ & $-1 \%$ \\
\hline & High Price ( 3 pm- 6 pm) & 27.8 & 3.0 & 0.33 & 0.04 & $6 \%$ & $1 \%$ \\
\hline \multirow[t]{2}{*}{ CPP-4 } & Moderate Price (12 pm-3 pm) & 79.7 & 22.6 & 0.95 & 0.27 & $18 \%$ & $5 \%$ \\
\hline & High Price ( 3 pm-6 pm) & 197.8 & 54.4 & 2.36 & 0.65 & $44 \%$ & $12 \%$ \\
\hline \multirow[t]{2}{*}{ CPP-5 } & Moderate Price (12 pm-3 pm) & 253.4 & 78.4 & 3.03 & 0.94 & $49 \%$ & $15 \%$ \\
\hline & High Price ( 3 pm- 6 pm) & 321.6 & 145.3 & 3.84 & 1.74 & $62 \%$ & $28 \%$ \\
\hline \multirow[t]{2}{*}{ CPP-6 } & Moderate Price ( $12 \mathrm{pm}-3 \mathrm{pm})$ & 208.3 & 71.4 & 2.49 & 0.85 & $40 \%$ & $14 \%$ \\
\hline & High Price ( 3 pm- 6 pm) & 333.1 & 132.1 & 3.98 & 1.58 & $64 \%$ & $26 \%$ \\
\hline \multirow[t]{2}{*}{ CPP-7 } & Moderate Price (12 pm-3 pm) & 247.7 & 117.9 & 2.96 & 1.41 & $50 \%$ & $24 \%$ \\
\hline & High Price ( 3 pm- 6 pm) & 273.6 & 106.9 & 3.27 & 1.28 & $55 \%$ & $22 \%$ \\
\hline \multirow[t]{2}{*}{ CPP-8 } & Moderate Price ( $12 \mathrm{pm}-3 \mathrm{pm})$ & 289.9 & 147.7 & 3.46 & 1.76 & $59 \%$ & $30 \%$ \\
\hline & High Price ( 3 pm- 6 pm) & 190.1 & 50.9 & 2.27 & 0.61 & $38 \%$ & $10 \%$ \\
\hline \multirow[t]{2}{*}{ CPP-9 } & Moderate Price ( $12 \mathrm{pm}-3 \mathrm{pm})$ & 320.6 & 150.7 & 3.83 & 1.80 & $62 \%$ & $29 \%$ \\
\hline & High Price ( 3 pm-6 pm) & 282.2 & 120.2 & 3.37 & 1.44 & $55 \%$ & $23 \%$ \\
\hline \multirow[t]{2}{*}{ CPP- 10} & Moderate Price ( $12 \mathrm{pm}-3 \mathrm{pm})$ & 273.6 & 116.1 & 3.27 & 1.39 & $53 \%$ & $22 \%$ \\
\hline & High Price ( 3 pm- 6 pm) & 268.8 & 64.7 & 3.21 & 0.77 & $52 \%$ & $13 \%$ \\
\hline \multirow[t]{2}{*}{ CPP-11 } & Moderate Price ( $12 \mathrm{pm}-3 \mathrm{pm})$ & 94.1 & 60.2 & 1.12 & 0.72 & $17 \%$ & $11 \%$ \\
\hline & High Price ( 3 pm-6 pm) & 112.3 & 67.6 & 1.34 & 0.81 & $20 \%$ & $12 \%$ \\
\hline Average & Peak Period ( 12 pm-3 pm) & 234.2 & 94.2 & 2.80 & 1.13 & $46 \%$ & $18 \%$ \\
\hline
\end{tabular}




\section{Table D 7: Demand Shed on Auto-DR Days - Two Parkside}

\begin{tabular}{|c|c|c|c|c|c|c|c|}
\hline \multirow[t]{2}{*}{ DATE } & \multirow{2}{*}{ Period } & \multicolumn{2}{|c|}{$\mathbf{k W}$} & \multicolumn{2}{|c|}{$\mathbf{W} / \mathrm{FT}^{2}$} & \multicolumn{2}{|c|}{ WBP\% } \\
\hline & & MAX & Ave & Max & AVE & MAX & Ave \\
\hline \multirow[t]{2}{*}{ CPP- 1} & Moderate Price (12 pm-3 pm) & 84.5 & 51.4 & 1.01 & 0.61 & $21 \%$ & $13 \%$ \\
\hline & High Price ( 3 pm- 6 pm) & 44.2 & 12.1 & 0.53 & 0.14 & $11 \%$ & $3 \%$ \\
\hline \multirow[t]{2}{*}{ CPP-2 } & Moderate Price (12 pm-3 pm) & 87.8 & 43.2 & 1.05 & 0.52 & $22 \%$ & $11 \%$ \\
\hline & High Price ( 3 pm- 6 pm) & 136.3 & 9.3 & 1.63 & 0.11 & $34 \%$ & $2 \%$ \\
\hline \multirow[t]{2}{*}{ CPP-3 } & Moderate Price ( 12 pm-3 pm) & 88.8 & 54.5 & 1.06 & 0.65 & $22 \%$ & $14 \%$ \\
\hline & High Price ( 3 pm- 6 pm) & 55.7 & -18.0 & 0.67 & -0.22 & $14 \%$ & $-5 \%$ \\
\hline \multirow[t]{2}{*}{ CPP- 4} & Moderate Price ( $12 \mathrm{pm}-3 \mathrm{pm}$ ) & 52.8 & 2.5 & 0.63 & 0.03 & $15 \%$ & $1 \%$ \\
\hline & High Price ( 3 pm- 6 pm) & 66.7 & 34.3 & 0.80 & 0.41 & $19 \%$ & $10 \%$ \\
\hline \multirow[t]{2}{*}{ CPP-5 } & Moderate Price (12 pm-3 pm) & 132.5 & 86.5 & 1.58 & 1.03 & $32 \%$ & $21 \%$ \\
\hline & High Price ( 3 pm- 6 pm) & 158.9 & 82.2 & 1.90 & 0.98 & $39 \%$ & $20 \%$ \\
\hline \multirow[t]{2}{*}{ CPP-6 } & Moderate Price ( $12 \mathrm{pm}-3 \mathrm{pm}$ ) & 104.2 & 60.1 & 1.24 & 0.72 & $25 \%$ & $15 \%$ \\
\hline & High Price ( 3 pm- 6 pm) & 162.2 & 103.6 & 1.94 & 1.24 & $39 \%$ & $25 \%$ \\
\hline \multirow[t]{2}{*}{ CPP-7 } & Moderate Price (12 pm-3 pm) & 70.1 & 30.1 & 0.84 & 0.36 & $18 \%$ & $8 \%$ \\
\hline & High Price ( 3 pm- 6 pm) & 104.6 & 33.1 & 1.25 & 0.40 & $27 \%$ & $8 \%$ \\
\hline \multirow[t]{2}{*}{ CPP-8 } & Moderate Price (12 pm-3 pm) & 73.9 & 27.8 & 0.88 & 0.33 & $19 \%$ & $7 \%$ \\
\hline & High Price ( 3 pm- 6 pm) & 76.3 & 26.9 & 0.91 & 0.32 & $19 \%$ & $7 \%$ \\
\hline \multirow[t]{2}{*}{ CPP-9 } & Moderate Price (12 pm-3 pm) & 37.9 & -1.7 & 0.45 & -0.02 & $13 \%$ & $-1 \%$ \\
\hline & High Price ( 3 pm- 6 pm) & 32.2 & -13.1 & 0.38 & -0.16 & $11 \%$ & $-4 \%$ \\
\hline \multirow[t]{2}{*}{ CPP- 10} & Moderate Price ( 12 pm-3 pm) & 39.8 & 22.3 & 0.48 & 0.27 & $13 \%$ & $7 \%$ \\
\hline & High Price ( 3 pm- 6 pm) & 37.0 & -12.1 & 0.44 & -0.14 & $12 \%$ & $-4 \%$ \\
\hline \multirow[t]{2}{*}{ CPP-11 } & Moderate Price (12 pm-3 pm) & 127.2 & 34.4 & 1.52 & 0.41 & $33 \%$ & $9 \%$ \\
\hline & High Price ( 3 pm- 6 pm) & 73.0 & 8.4 & 0.87 & 0.10 & $19 \%$ & $2 \%$ \\
\hline Average & Peak Period ( 12 pm-3 pm) & 84.3 & 32.8 & 1.01 & 0.39 & $22 \%$ & $8 \%$ \\
\hline
\end{tabular}




\section{Table D 8: Demand Shed on Auto-Dr Days - Three Carnegie Plaza}

\begin{tabular}{|c|c|c|c|c|c|c|c|}
\hline \multirow{2}{*}{ DATE } & \multirow[t]{2}{*}{ Period } & \multicolumn{2}{|c|}{$\mathbf{k W}$} & \multicolumn{2}{|c|}{$\mathrm{W} / \mathrm{FT}^{2}$} & \multicolumn{2}{|c|}{ WBP\% } \\
\hline & & MaX & Ave & $\operatorname{MAX}$ & Ave & Max & Ave \\
\hline \multirow[t]{2}{*}{ CPP-1 } & Moderate Price ( $12 \mathrm{pm}-3 \mathrm{pm}$ ) & 56.6 & 24.6 & 0.68 & 0.29 & $24 \%$ & $10 \%$ \\
\hline & High Price ( 3 pm- 6 pm) & 31.7 & -37.6 & 0.38 & -0.45 & $13 \%$ & $-16 \%$ \\
\hline \multirow[t]{2}{*}{ CPP-2 } & Moderate Price ( $12 \mathrm{pm}-3 \mathrm{pm})$ & 43.2 & 4.3 & 0.52 & 0.05 & $18 \%$ & $2 \%$ \\
\hline & High Price ( 3 pm- 6 pm) & 48.0 & -23.2 & 0.57 & -0.28 & $20 \%$ & $-10 \%$ \\
\hline \multirow[t]{2}{*}{ CPP-3 } & Moderate Price (12 pm-3 pm) & 2.9 & -11.4 & 0.03 & -0.14 & $1 \%$ & $-5 \%$ \\
\hline & High Price ( 3 pm-6 pm) & 20.2 & -20.9 & 0.24 & -0.25 & $8 \%$ & $-9 \%$ \\
\hline \multirow[t]{2}{*}{ CPP-4 } & Moderate Price ( $12 \mathrm{pm}-3 \mathrm{pm})$ & 63.4 & 50.6 & 0.76 & 0.60 & $27 \%$ & $21 \%$ \\
\hline & High Price ( 3 pm- 6 pm) & 68.2 & 51.6 & 0.81 & 0.62 & $29 \%$ & $22 \%$ \\
\hline \multirow[t]{2}{*}{ CPP-5 } & Moderate Price (12 pm-3 pm) & 69.1 & 54.5 & 0.83 & 0.65 & $27 \%$ & $21 \%$ \\
\hline & High Price ( 3 pm- 6 pm) & 86.4 & 54.2 & 1.03 & 0.65 & $34 \%$ & $21 \%$ \\
\hline \multirow[t]{2}{*}{ CPP-6 } & Moderate Price ( $12 \mathrm{pm}-3 \mathrm{pm})$ & 71.0 & 50.5 & 0.85 & 0.60 & $28 \%$ & $20 \%$ \\
\hline & High Price ( 3 pm-6 pm) & 64.3 & 45.0 & 0.77 & 0.54 & $25 \%$ & $18 \%$ \\
\hline \multirow[t]{2}{*}{ CPP-7 } & Moderate Price ( $12 \mathrm{pm}-3 \mathrm{pm})$ & 111.4 & 101.1 & 1.33 & 1.21 & $36 \%$ & $33 \%$ \\
\hline & High Price ( 3 pm- 6 pm) & 84.5 & 50.6 & 1.01 & 0.61 & $27 \%$ & $16 \%$ \\
\hline \multirow[t]{2}{*}{ CPP-8 } & Moderate Price ( $12 \mathrm{pm}-3 \mathrm{pm})$ & 90.2 & 77.5 & 1.08 & 0.93 & $29 \%$ & $25 \%$ \\
\hline & High Price ( 3 pm-6 pm) & 66.2 & 32.8 & 0.79 & 0.39 & $21 \%$ & $11 \%$ \\
\hline \multirow[t]{2}{*}{ CPP-9 } & Moderate Price ( $12 \mathrm{pm}-3 \mathrm{pm})$ & 82.6 & 66.1 & 0.99 & 0.79 & $28 \%$ & $22 \%$ \\
\hline & High Price ( 3 pm-6 pm) & 72.0 & 56.4 & 0.86 & 0.67 & $25 \%$ & $19 \%$ \\
\hline \multirow[t]{2}{*}{ CPP-10 } & Moderate Price ( $12 \mathrm{pm}-3 \mathrm{pm})$ & 74.9 & 59.2 & 0.89 & 0.71 & $25 \%$ & $20 \%$ \\
\hline & High Price ( 3 pm- 6 pm) & 63.4 & 43.2 & 0.76 & 0.52 & $22 \%$ & $15 \%$ \\
\hline \multirow[t]{2}{*}{ CPP-11 } & Moderate Price ( $12 \mathrm{pm}-3 \mathrm{pm})$ & 64.3 & 51.3 & 0.77 & 0.61 & $23 \%$ & $18 \%$ \\
\hline & High Price ( 3 pm-6 pm) & 58.6 & 37.2 & 0.70 & 0.44 & $21 \%$ & $13 \%$ \\
\hline Average & Peak Period (12 pm-3 pm) & 74.4 & 55.1 & 0.89 & 0.66 & $27 \%$ & $20 \%$ \\
\hline
\end{tabular}




\section{Table D 9: Demand Shed on Auto-DR Days - Brier Corporate Center}

\begin{tabular}{|c|c|c|c|c|c|c|c|}
\hline \multirow[t]{2}{*}{ DATE } & \multirow[t]{2}{*}{ Period } & \multicolumn{2}{|c|}{$\mathbf{k W}$} & \multicolumn{2}{|c|}{$\mathbf{W} / \mathrm{FT}^{2}$} & \multicolumn{2}{|c|}{ WBP\% } \\
\hline & & MAX & AVE & MAX & Ave & MAX & Ave \\
\hline \multirow[t]{2}{*}{ CPP-1 } & Moderate Price ( $12 \mathrm{pm}-3 \mathrm{pm}$ ) & 45.6 & 25.6 & 0.54 & 0.31 & $11 \%$ & $6 \%$ \\
\hline & High Price ( 3 pm- 6 pm) & 24.0 & -68.8 & 0.29 & -0.82 & $6 \%$ & $-16 \%$ \\
\hline \multirow[t]{2}{*}{ CPP-2 } & Moderate Price (12 pm-3 pm) & 21.6 & 12.0 & 0.26 & 0.14 & $5 \%$ & $3 \%$ \\
\hline & High Price ( 3 pm- 6 pm) & 16.8 & -51.8 & 0.20 & -0.62 & $4 \%$ & $-12 \%$ \\
\hline \multirow[t]{2}{*}{ CPP-3 } & Moderate Price (12 pm-3 pm) & 12.0 & 0.8 & 0.14 & 0.01 & $3 \%$ & $0 \%$ \\
\hline & High Price ( 3 pm- 6 pm) & 26.4 & -36.0 & 0.32 & -0.43 & $6 \%$ & $-8 \%$ \\
\hline \multirow[t]{2}{*}{ CPP- 4} & Moderate Price ( $12 \mathrm{pm}-3 \mathrm{pm}$ ) & 28.8 & 16.2 & 0.34 & 0.19 & $7 \%$ & $4 \%$ \\
\hline & High Price ( 3 pm- 6 pm) & 28.8 & 13.2 & 0.34 & 0.16 & $7 \%$ & $3 \%$ \\
\hline \multirow[t]{2}{*}{ CPP-5 } & Moderate Price ( $12 \mathrm{pm}-3 \mathrm{pm})$ & 72.0 & 55.8 & 0.86 & 0.67 & $15 \%$ & $12 \%$ \\
\hline & High Price ( 3 pm- 6 pm) & 84.0 & 71.2 & 1.00 & 0.85 & $18 \%$ & $15 \%$ \\
\hline \multirow[t]{2}{*}{ CPP-6 } & Moderate Price ( $12 \mathrm{pm}-3 \mathrm{pm}$ ) & 74.4 & 52.8 & 0.89 & 0.63 & $16 \%$ & $11 \%$ \\
\hline & High Price ( 3 pm-6 pm) & 69.6 & 55.6 & 0.83 & 0.66 & $15 \%$ & $12 \%$ \\
\hline \multirow[t]{2}{*}{ CPP-7 } & Moderate Price (12 pm-3 pm) & 67.2 & 47.2 & 0.80 & 0.56 & $15 \%$ & $10 \%$ \\
\hline & High Price ( 3 pm- 6 pm) & 52.8 & 26.2 & 0.63 & 0.31 & $12 \%$ & $6 \%$ \\
\hline \multirow[t]{2}{*}{ CPP-8 } & Moderate Price ( $12 \mathrm{pm}-3 \mathrm{pm})$ & 69.6 & 47.0 & 0.83 & 0.56 & $15 \%$ & $10 \%$ \\
\hline & High Price ( 3 pm- 6 pm) & 38.4 & 14.8 & 0.46 & 0.18 & $9 \%$ & $3 \%$ \\
\hline \multirow[t]{2}{*}{ CPP-9 } & Moderate Price ( 12 pm-3 pm) & 21.6 & 6.0 & 0.26 & 0.07 & $5 \%$ & $1 \%$ \\
\hline & High Price ( 3 pm-6 pm) & 24.0 & 5.6 & 0.29 & 0.07 & $6 \%$ & $1 \%$ \\
\hline \multirow[t]{2}{*}{ CPP-10 } & Moderate Price ( $12 \mathrm{pm}-3 \mathrm{pm})$ & 12.0 & 0.8 & 0.14 & 0.01 & $3 \%$ & $0 \%$ \\
\hline & High Price ( 3 pm- 6 pm) & 21.6 & -2.4 & 0.26 & -0.03 & $5 \%$ & $-1 \%$ \\
\hline \multirow[t]{2}{*}{ CPP-11 } & Moderate Price ( $12 \mathrm{pm}-3 \mathrm{pm}$ ) & 57.6 & 39.8 & 0.69 & 0.48 & $12 \%$ & $8 \%$ \\
\hline & High Price ( 3 pm-6 pm) & 38.4 & 25.6 & 0.46 & 0.31 & $8 \%$ & $5 \%$ \\
\hline Average & Peak Period (12 pm-3 pm) & 47.6 & 29.7 & 0.57 & 0.35 & $10 \%$ & $6 \%$ \\
\hline
\end{tabular}




\section{Table D 10: Demand Shed on Auto-DR Days - Vanderbilt Plaza}

\begin{tabular}{|c|c|c|c|c|c|c|c|}
\hline \multirow[t]{2}{*}{ DATE } & \multirow{2}{*}{ PERIOD } & \multicolumn{2}{|c|}{$\mathbf{k W}$} & \multicolumn{2}{|c|}{$\mathrm{W} / \mathrm{FT}^{2}$} & \multicolumn{2}{|c|}{ WBP\% } \\
\hline & & MAX & AVE & MAX & AVE & MAX & Ave \\
\hline \multirow[t]{2}{*}{ CPP-1 } & Moderate Price (12 pm-3 pm) & 87.8 & 59.5 & 1.05 & 0.71 & $16 \%$ & $11 \%$ \\
\hline & High Price ( 3 pm- 6 pm) & 90.7 & 25.8 & 1.08 & 0.31 & $16 \%$ & $5 \%$ \\
\hline \multirow[t]{2}{*}{ CPP-2 } & Moderate Price (12 pm-3 pm) & 126.7 & 85.6 & 1.51 & 1.02 & $23 \%$ & $15 \%$ \\
\hline & High Price ( 3 pm- 6 pm) & 157.0 & 49.2 & 1.88 & 0.59 & $28 \%$ & $9 \%$ \\
\hline \multirow[t]{2}{*}{ CPP-3 } & Moderate Price (12 pm-3 pm) & 37.4 & 23.4 & 0.45 & 0.28 & $7 \%$ & $4 \%$ \\
\hline & High Price ( 3 pm-6 pm) & 106.6 & 24.0 & 1.27 & 0.29 & $19 \%$ & $4 \%$ \\
\hline \multirow[t]{2}{*}{ CPP-4 } & Moderate Price (12 pm-3 pm) & 97.9 & 70.8 & 1.17 & 0.85 & $22 \%$ & $16 \%$ \\
\hline & High Price ( 3 pm-6 pm) & 89.3 & 49.3 & 1.07 & 0.59 & $20 \%$ & $11 \%$ \\
\hline \multirow[t]{2}{*}{ CPP-5 } & Moderate Price (12 pm-3 pm) & 178.6 & 131.6 & 2.13 & 1.57 & $34 \%$ & $25 \%$ \\
\hline & High Price ( 3 pm- 6 pm) & 161.3 & 121.3 & 1.93 & 1.45 & $31 \%$ & $23 \%$ \\
\hline \multirow[t]{2}{*}{ CPP-6 } & Moderate Price (12 pm-3 pm) & 169.9 & 144.6 & 2.03 & 1.73 & $32 \%$ & $28 \%$ \\
\hline & High Price ( 3 pm- 6 pm) & 139.7 & 94.8 & 1.67 & 1.13 & $27 \%$ & $18 \%$ \\
\hline \multirow[t]{2}{*}{ CPP-7 } & Moderate Price (12 pm-3 pm) & 93.6 & 61.6 & 1.12 & 0.74 & $21 \%$ & $14 \%$ \\
\hline & High Price ( 3 pm- 6 pm) & 54.7 & 12.8 & 0.65 & 0.15 & $13 \%$ & $3 \%$ \\
\hline \multirow[t]{2}{*}{ CPP-8 } & Moderate Price ( $12 \mathrm{pm}-3 \mathrm{pm})$ & 105.1 & 68.0 & 1.26 & 0.81 & $24 \%$ & $16 \%$ \\
\hline & High Price ( 3 pm- 6 pm) & 106.6 & 34.4 & 1.27 & 0.41 & $24 \%$ & $8 \%$ \\
\hline \multirow[t]{2}{*}{ CPP-9 } & Moderate Price ( $12 \mathrm{pm}-3 \mathrm{pm})$ & 76.3 & 54.5 & 0.91 & 0.65 & $18 \%$ & $13 \%$ \\
\hline & High Price ( 3 pm-6 pm) & 70.6 & 28.3 & 0.84 & 0.34 & $16 \%$ & $7 \%$ \\
\hline \multirow[t]{2}{*}{ CPP- 10} & Moderate Price ( $12 \mathrm{pm}-3 \mathrm{pm})$ & 80.6 & 56.6 & 0.96 & 0.68 & $19 \%$ & $13 \%$ \\
\hline & High Price ( 3 pm- 6 pm) & 79.2 & 14.6 & 0.95 & 0.17 & $18 \%$ & $3 \%$ \\
\hline \multirow[t]{2}{*}{ CPP-11 } & Moderate Price ( $12 \mathrm{pm}-3 \mathrm{pm})$ & 72.0 & 46.9 & 0.86 & 0.56 & $16 \%$ & $10 \%$ \\
\hline & High Price ( 3 pm- 6 pm) & 83.5 & 46.3 & 1.00 & 0.55 & $18 \%$ & $10 \%$ \\
\hline Average & Peak Period ( 12 pm-3 pm) & 103.7 & 64.8 & 1.24 & 0.77 & $22 \%$ & $14 \%$ \\
\hline
\end{tabular}




\section{Table D 11: Demand Shed on Auto-DR Days - Inland Regional Center}

\begin{tabular}{|c|c|c|c|c|c|c|c|}
\hline \multirow[t]{2}{*}{ DATE } & \multirow{2}{*}{ Period } & \multicolumn{2}{|c|}{$\mathbf{k W}$} & \multicolumn{2}{|c|}{$\mathbf{W} / \mathrm{FT}^{2}$} & \multicolumn{2}{|c|}{ WBP\% } \\
\hline & & MAX & AVE & MAX & AVE & MaX & Ave \\
\hline \multirow[t]{2}{*}{ CPP-1 } & Moderate Price (12 pm-3 pm) & 30.7 & 0.2 & 0.37 & 0.00 & $7 \%$ & $0 \%$ \\
\hline & High Price ( 3 pm- 6 pm) & 31.2 & -33.9 & 0.37 & -0.41 & $7 \%$ & $-8 \%$ \\
\hline \multirow[t]{2}{*}{ CPP-2 } & Moderate Price (12 pm-3 pm) & 25.9 & -8.8 & 0.31 & -0.11 & $6 \%$ & $-2 \%$ \\
\hline & High Price ( 3 pm- 6 pm) & 42.7 & -24.2 & 0.51 & -0.29 & $10 \%$ & $-6 \%$ \\
\hline \multirow[t]{2}{*}{ CPP-3 } & Moderate Price (12 pm-3 pm) & 23.0 & -9.7 & 0.28 & -0.12 & $5 \%$ & $-2 \%$ \\
\hline & High Price ( 3 pm- 6 pm) & 33.6 & -6.8 & 0.40 & -0.08 & $8 \%$ & $-2 \%$ \\
\hline \multirow[t]{2}{*}{ CPP- 4} & Moderate Price ( $12 \mathrm{pm}-3 \mathrm{pm})$ & 104.2 & 67.0 & 1.24 & 0.80 & $26 \%$ & $17 \%$ \\
\hline & High Price ( 3 pm- 6 pm) & 109.9 & 81.5 & 1.31 & 0.97 & $28 \%$ & $20 \%$ \\
\hline \multirow[t]{2}{*}{ CPP-5 } & Moderate Price ( $12 \mathrm{pm}-3 \mathrm{pm})$ & 107.0 & 61.1 & 1.28 & 0.73 & $23 \%$ & $13 \%$ \\
\hline & High Price ( 3 pm- 6 pm) & 185.3 & 117.1 & 2.21 & 1.40 & $39 \%$ & $25 \%$ \\
\hline \multirow[t]{2}{*}{ CPP-6 } & Moderate Price ( $12 \mathrm{pm}-3 \mathrm{pm}$ ) & 104.6 & 49.6 & 1.25 & 0.59 & $22 \%$ & $11 \%$ \\
\hline & High Price ( 3 pm- 6 pm) & 133.9 & 67.6 & 1.60 & 0.81 & $28 \%$ & $14 \%$ \\
\hline \multirow[t]{2}{*}{ CPP-7 } & Moderate Price ( $12 \mathrm{pm}-3 \mathrm{pm}$ ) & -9.6 & -27.3 & -0.11 & -0.33 & $-3 \%$ & $-7 \%$ \\
\hline & High Price ( 3 pm- 6 pm) & -1.9 & -23.8 & -0.02 & -0.28 & $-1 \%$ & $-6 \%$ \\
\hline \multirow[t]{2}{*}{ CPP-8 } & Moderate Price ( $12 \mathrm{pm}-3 \mathrm{pm})$ & -9.6 & -28.1 & -0.11 & -0.34 & $-3 \%$ & $-7 \%$ \\
\hline & High Price ( 3 pm- 6 pm) & 37.0 & -27.7 & 0.44 & -0.33 & $10 \%$ & $-7 \%$ \\
\hline \multirow[t]{2}{*}{ CPP-9 } & Moderate Price ( 12 pm-3 pm) & 49.4 & 7.9 & 0.59 & 0.09 & $13 \%$ & $2 \%$ \\
\hline & High Price ( 3 pm-6 pm) & 82.1 & 32.1 & 0.98 & 0.38 & $22 \%$ & $9 \%$ \\
\hline \multirow[t]{2}{*}{ CPP-10 } & Moderate Price ( $12 \mathrm{pm}-3 \mathrm{pm}$ ) & 55.7 & 12.0 & 0.67 & 0.14 & $15 \%$ & $3 \%$ \\
\hline & High Price ( 3 pm- 6 pm) & 58.6 & 20.3 & 0.70 & 0.24 & $16 \%$ & $5 \%$ \\
\hline \multirow[t]{2}{*}{ CPP-11 } & Moderate Price ( $12 \mathrm{pm}-3 \mathrm{pm}$ ) & 103.2 & 72.2 & 1.23 & 0.86 & $21 \%$ & $14 \%$ \\
\hline & High Price ( 3 pm- 6 pm) & 139.2 & 86.1 & 1.66 & 1.03 & $28 \%$ & $17 \%$ \\
\hline Average & Peak Period (12 pm-3 pm) & 78.1 & 35.5 & 0.93 & 0.42 & $18 \%$ & $8 \%$ \\
\hline
\end{tabular}




\section{Demand Ploton Auto-DR Events Days}

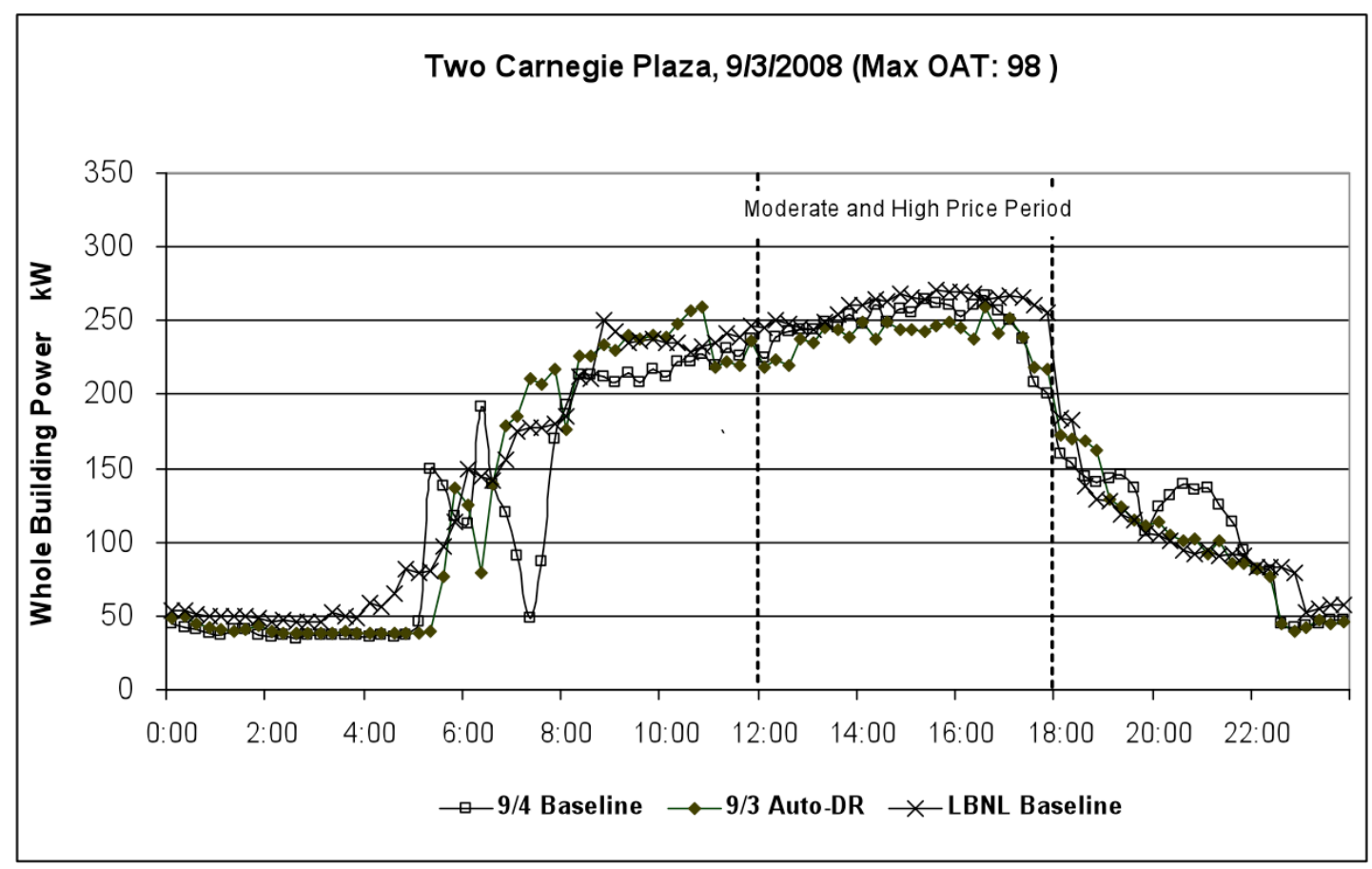

Figure D 1: Field Test Results of Pre-cooling Strategies on Auto-DR Day - Two Carnegie Plaza

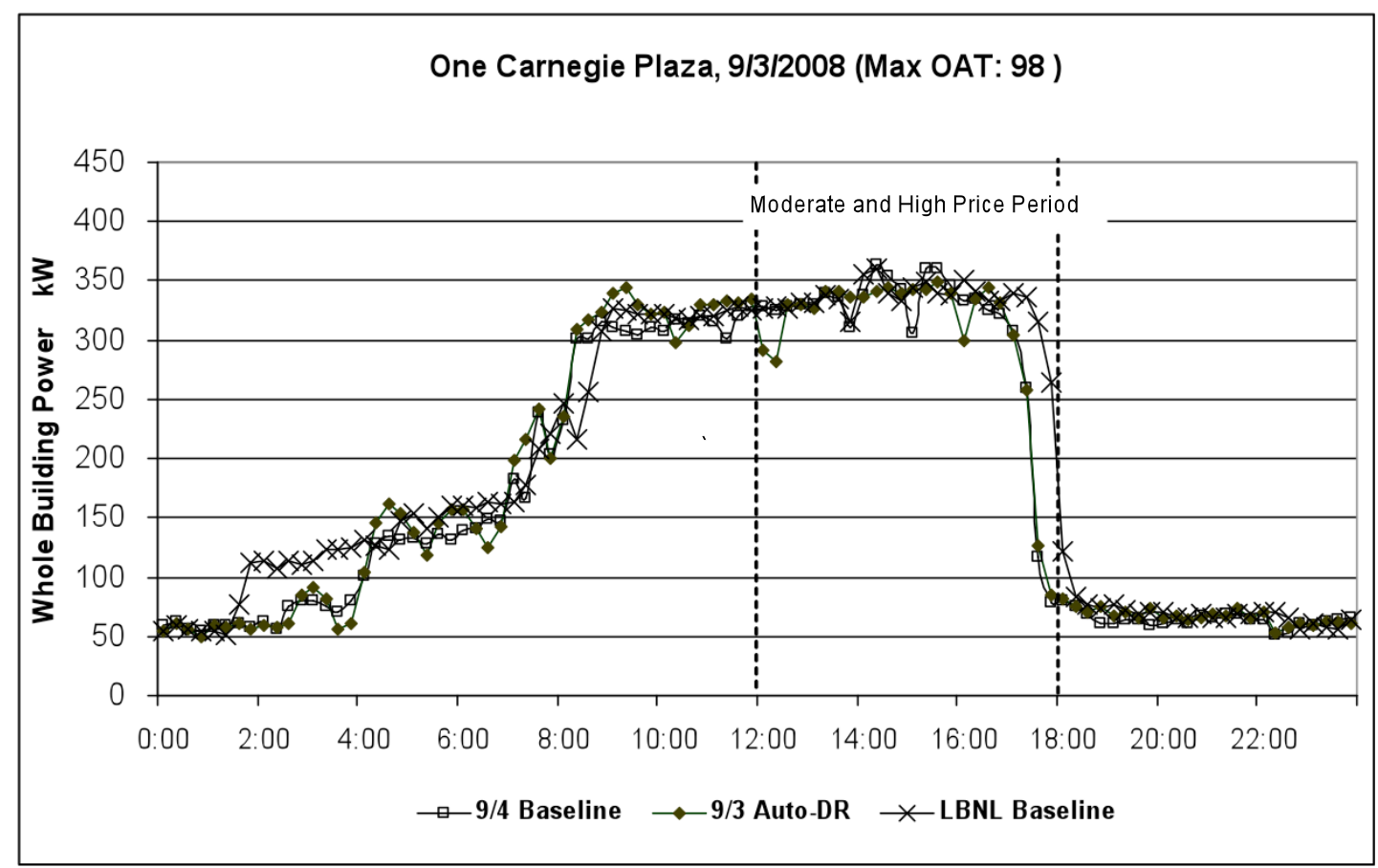

Figure D 2: Field Test Results of Pre-cooling Strategies on Auto-dr Day - One Carnegie Plaza 


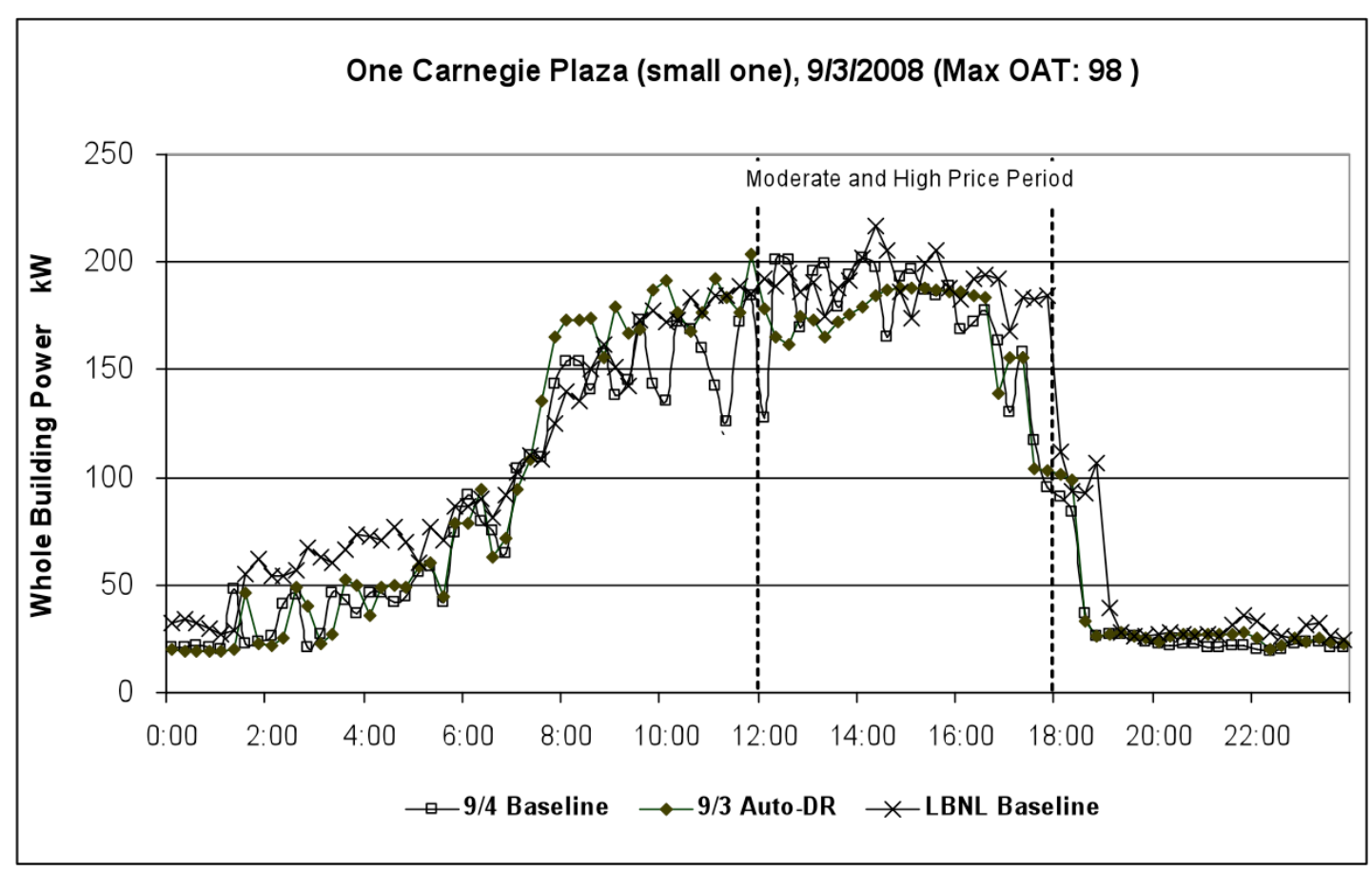

\section{Figure D 3: Field Test Results of Pre-cooling Strategies on Auto-Dr Day - One} Carnegie Plaza (small one)

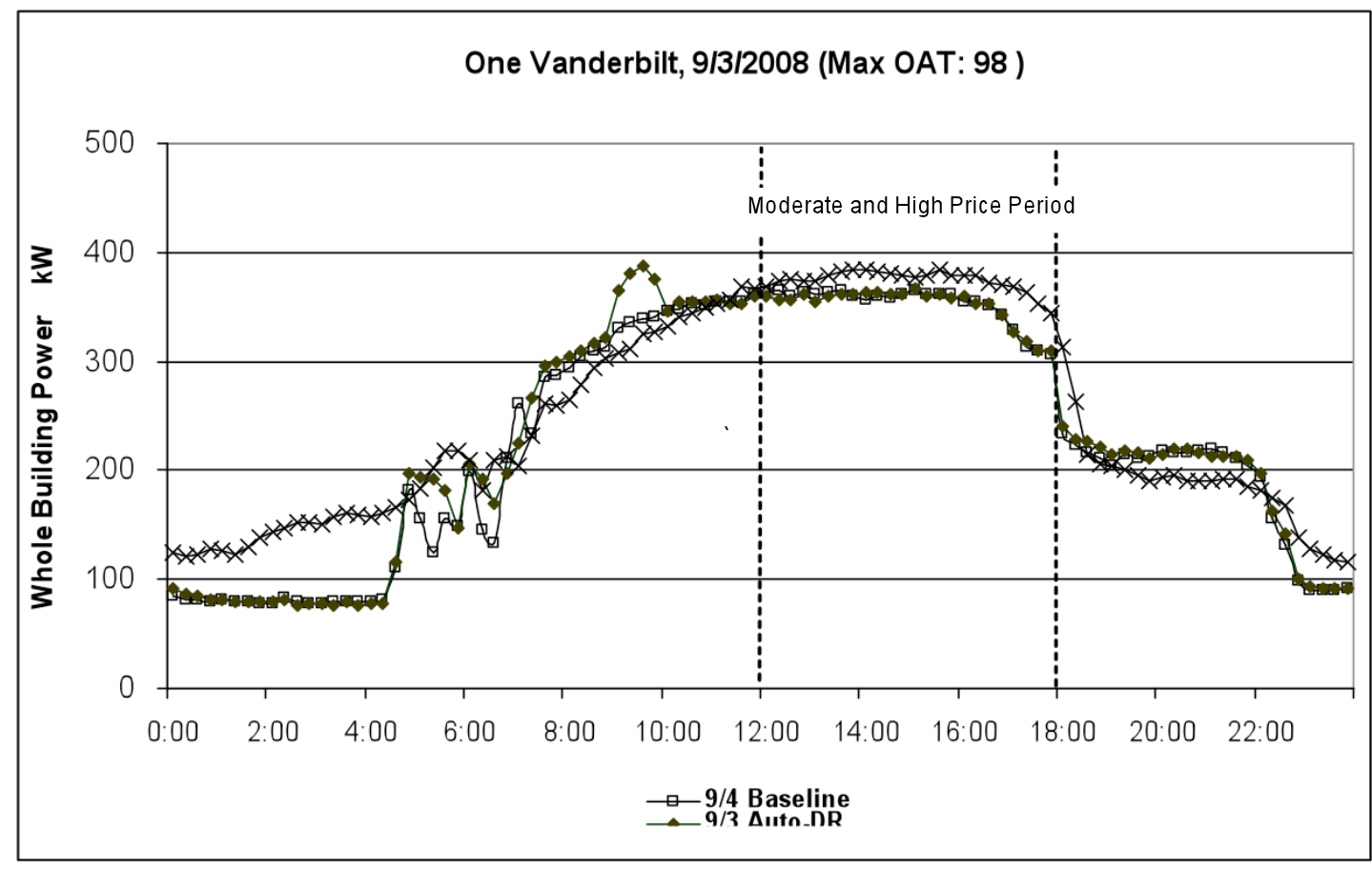

Figure D 4: Field Test Results of Pre-cooling Strategies on Auto-Dr Day - One VANDERBILT 


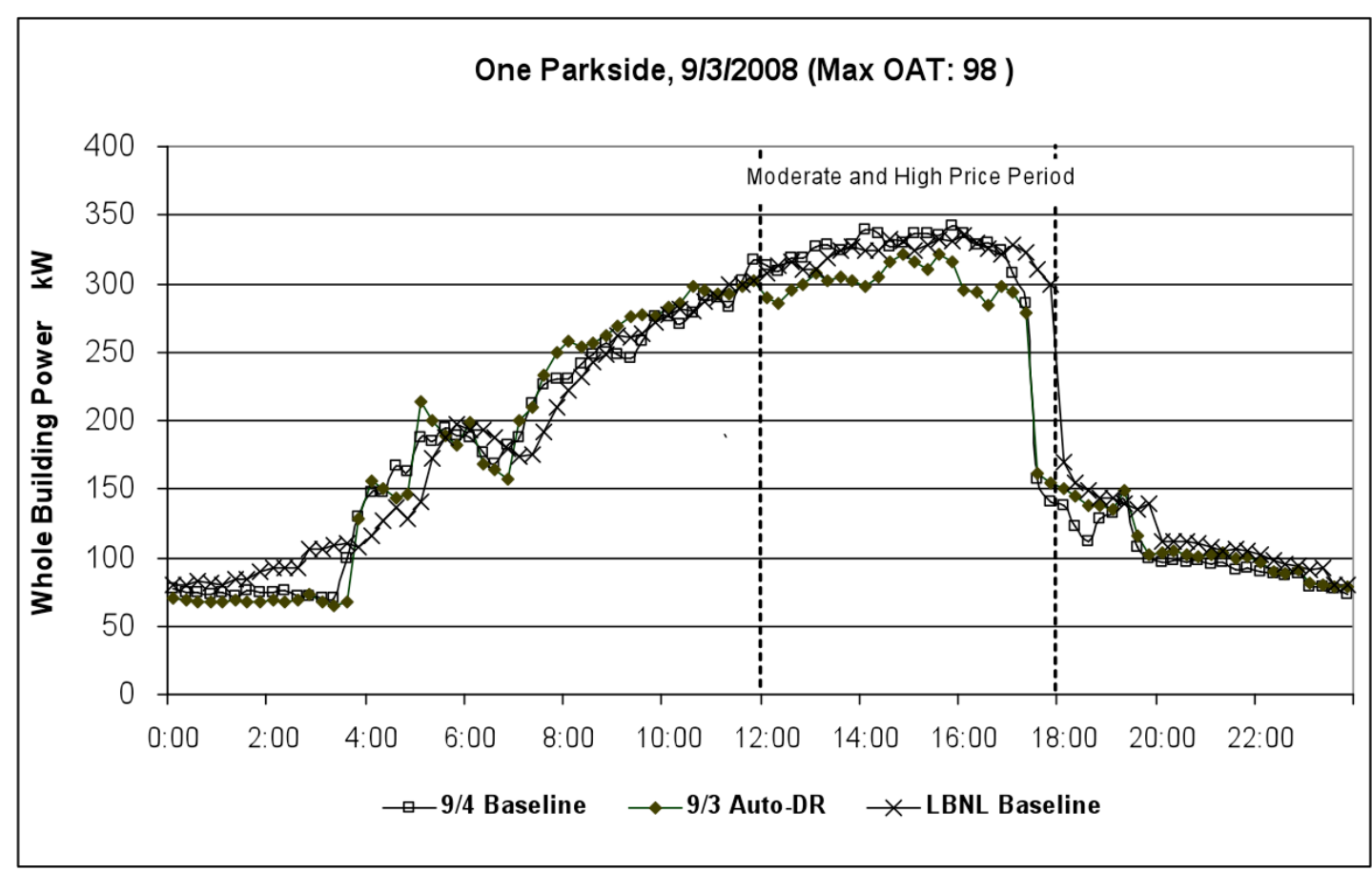

\section{Figure D 5: Field Test Results of Pre-cooling Strategies on Auto-Dr Day - One} PARKSIDE

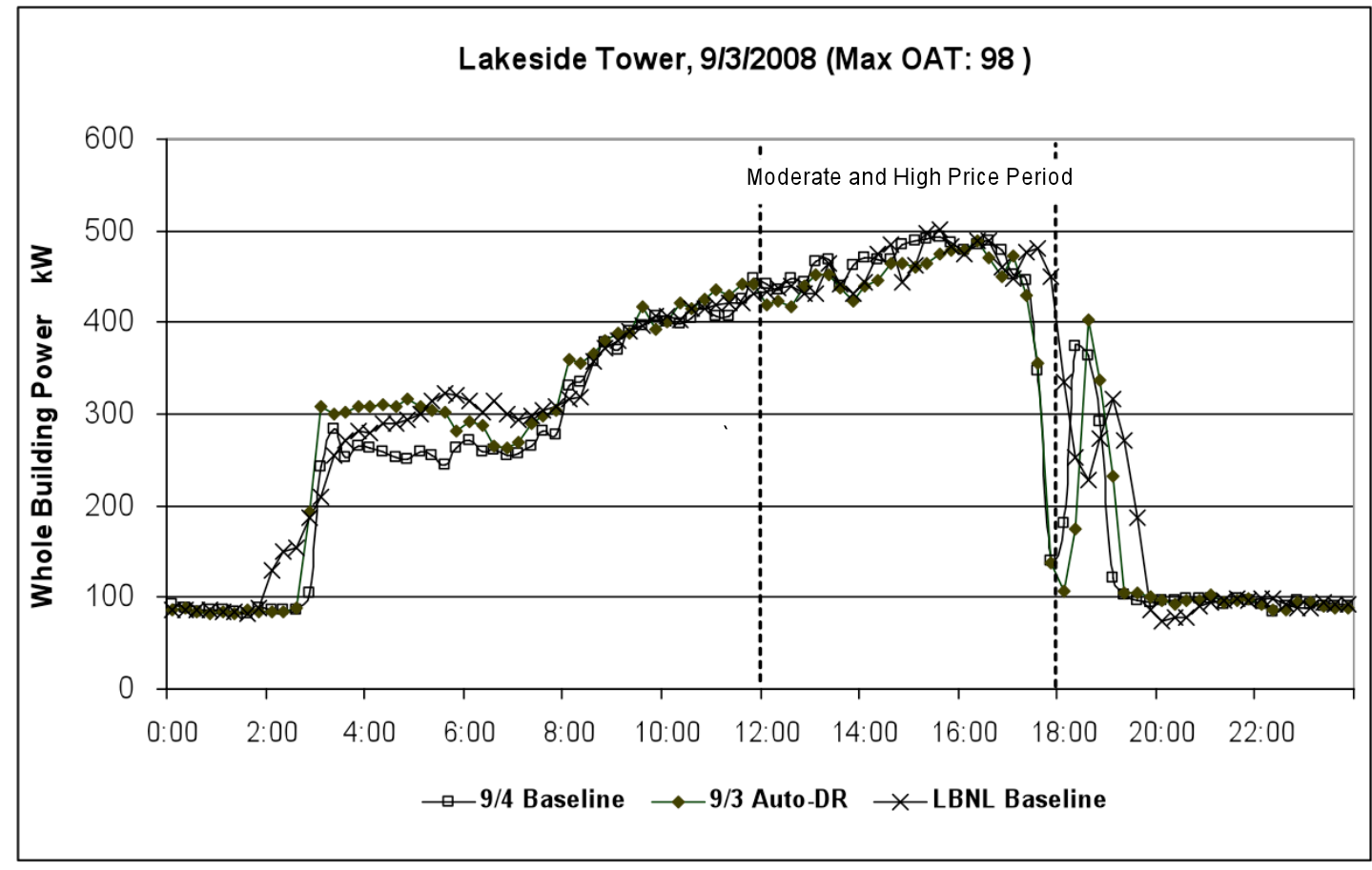

Figure D 6: Field Test Results of Pre-cooling Strategies on Auto-DR Day - Lakeside TOWER 


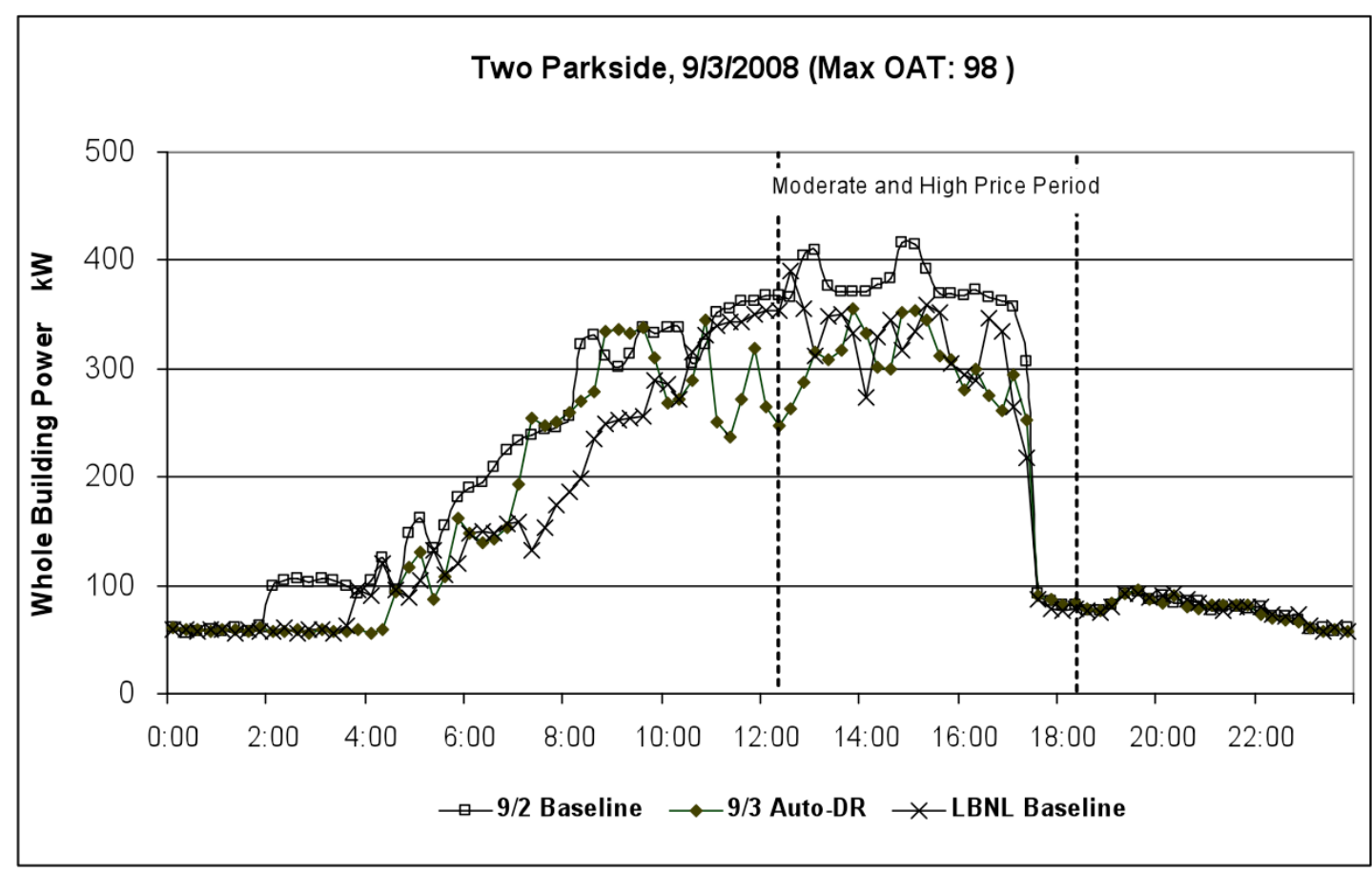

Figure D 7: Field Test Results of Pre-cooling Strategies on Auto-DR Day - Two PARKSIDE

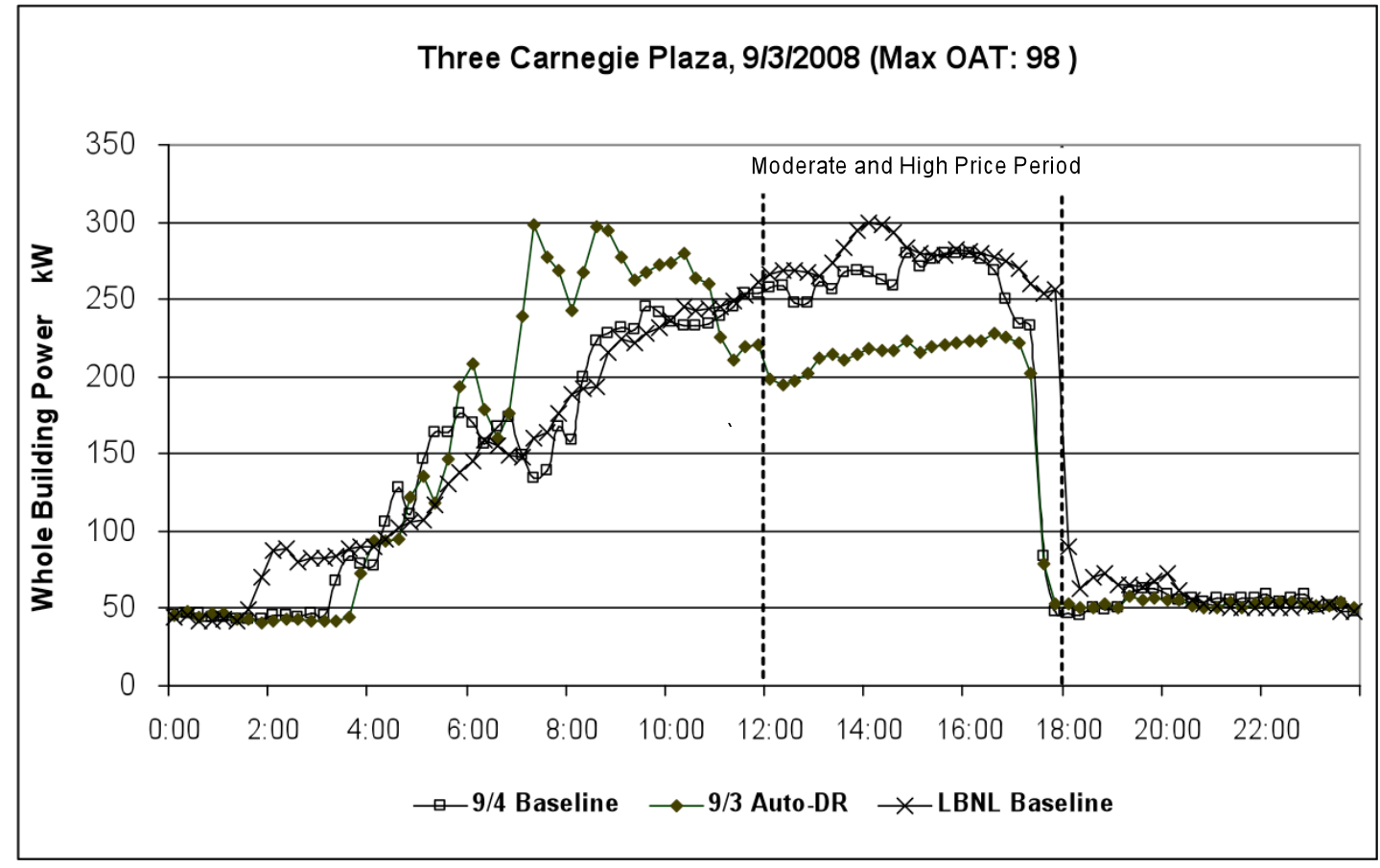

Figure D 8: Field Test Results of Pre-cooling Strategies on Auto-Dr Day - Three Carnegie Plaza 


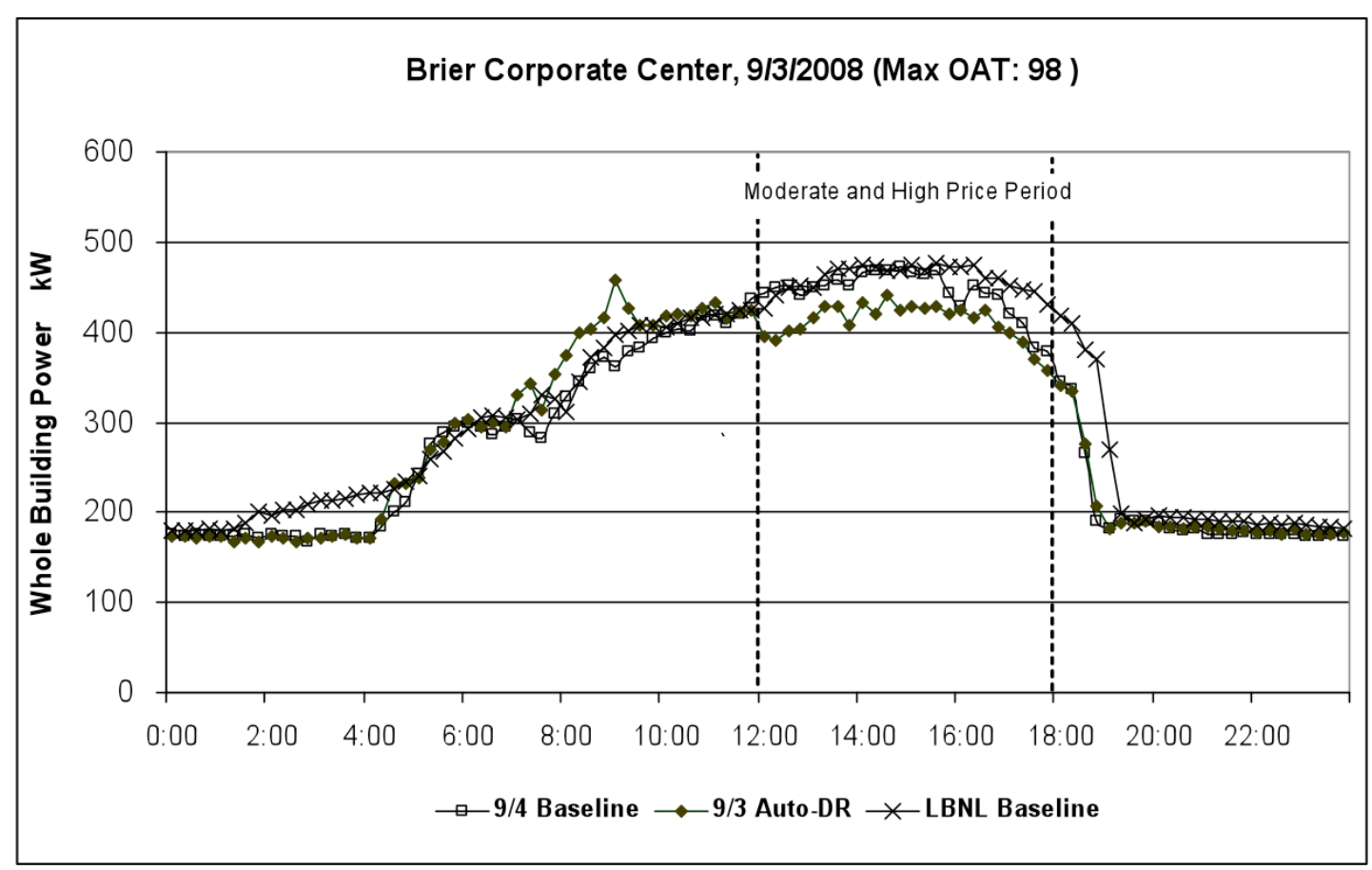

Figure D 9: Field Test Results of Pre-cooling Strategies on Auto-dR Day - Brier Corporate Center

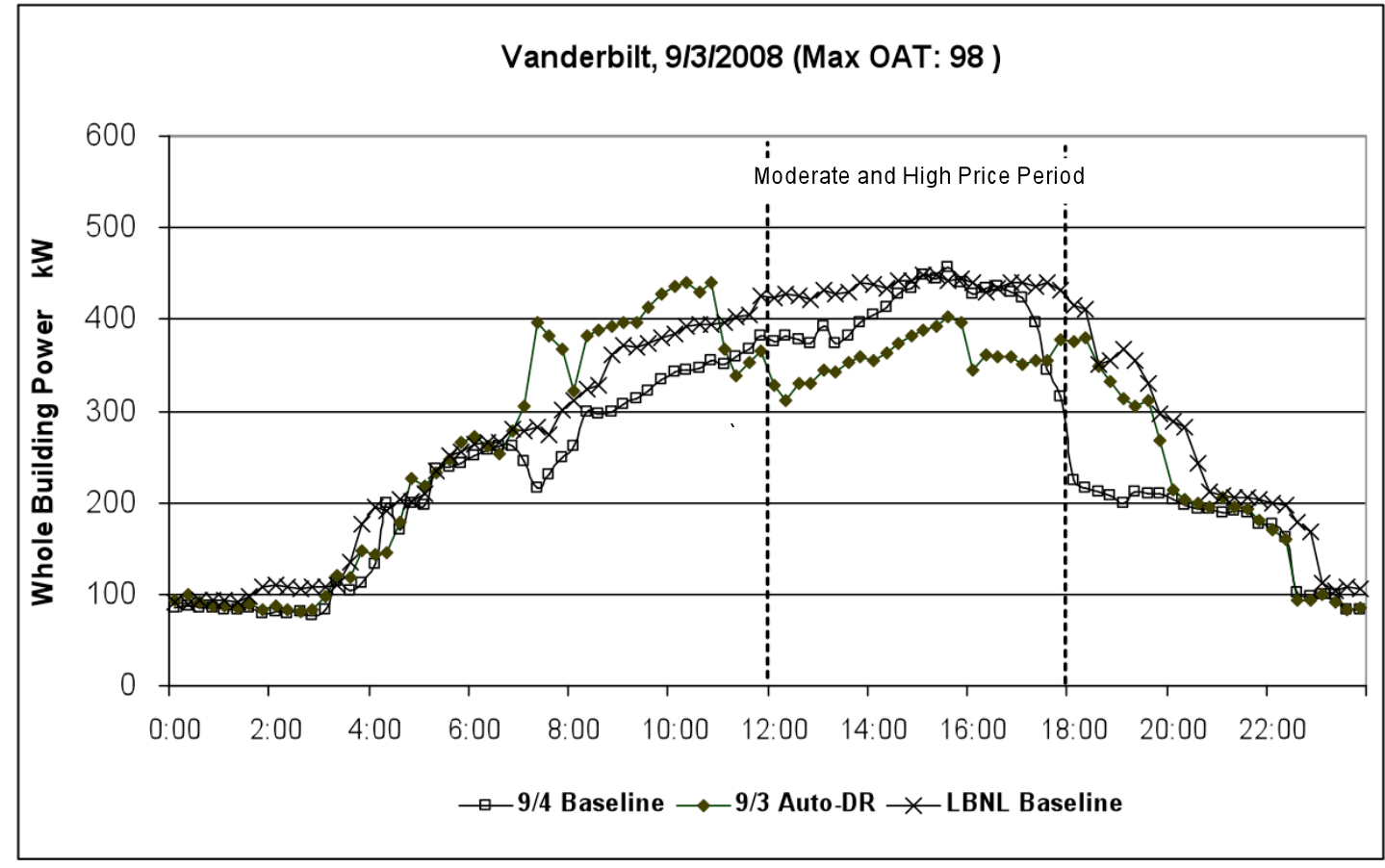

Figure D 10: Field Test Results of Pre-cooling Strategies on Auto-DR Day VANDERBILT 


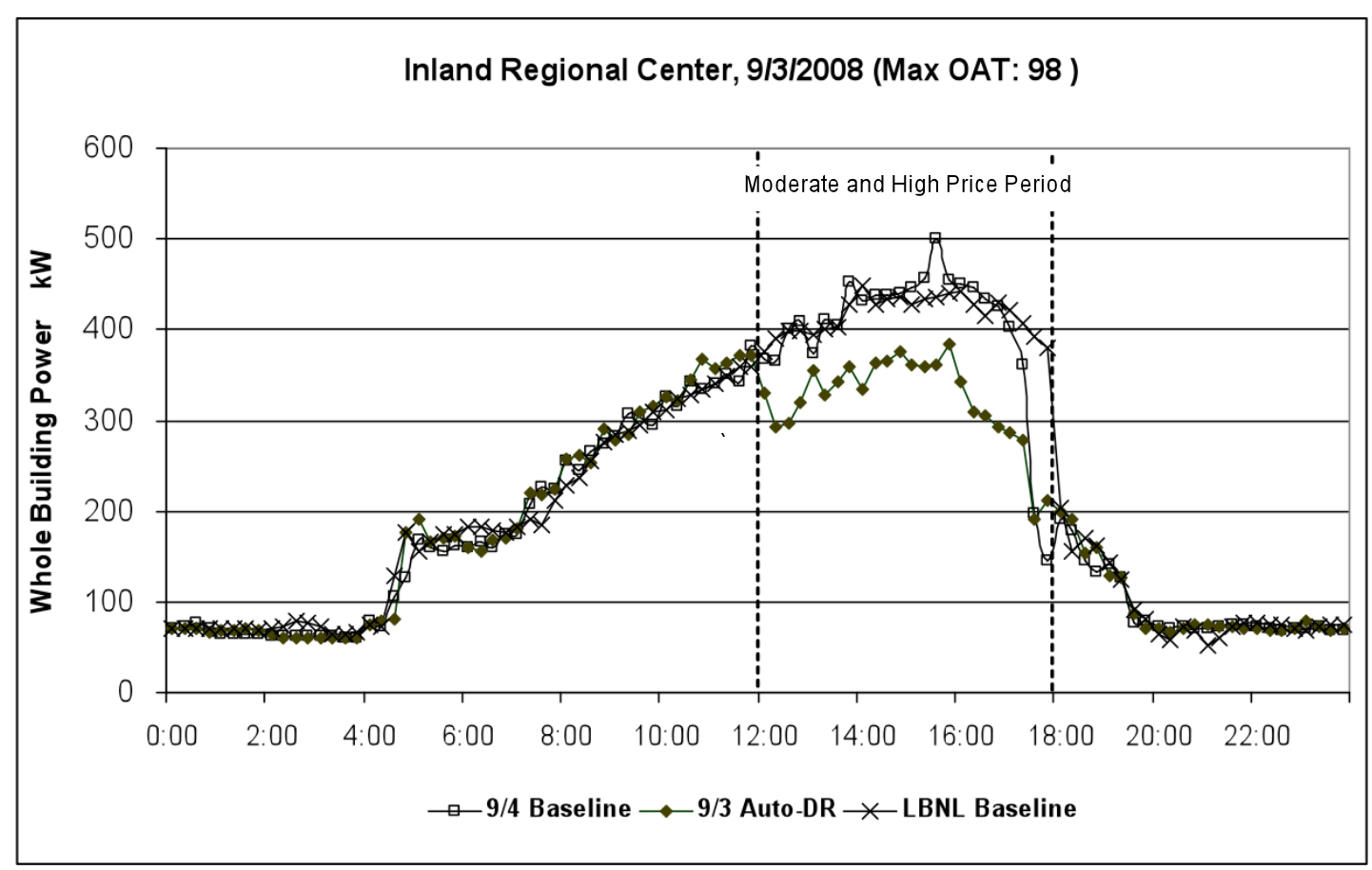

Figure D 11: Field Test Results of Pre-cooling Strategies on Auto-DR Day - Inland Regional Center 


\title{
EConomic Analysis on AUTO-DR Events Days
}

\author{
Table D 12: Summary of Energy and Demand Savings for Auto-DR events - Two \\ Carnegie Plaza
}

\begin{tabular}{|c|c|c|c|c|c|}
\hline \multirow[b]{2}{*}{ DATE } & \multirow[b]{2}{*}{ I NDEX } & \multicolumn{2}{|c|}{ ENERGY } & \multicolumn{2}{|c|}{ Demand } \\
\hline & & $\begin{array}{r}\text { CONSUMPTI ON } \\
\left(\mathrm{KW} \mathbf{W}_{\mathrm{H}}\right)\end{array}$ & $\begin{array}{r}\text { CHARGE } \\
(\$)\end{array}$ & $\begin{array}{r}\text { Max Demand } \\
\text { ON PeAK } \\
(\mathrm{kW})\end{array}$ & $\begin{array}{r}\text { Demand } \\
\text { SAVI NGS (\$) }\end{array}$ \\
\hline \multirow[t]{3}{*}{ CPP-1 } & Baseline & 3,715 & 1,352 & 293 & 4,667 \\
\hline & Actual Auto-DR Event & 3,535 & 1,234 & 301 & 4,795 \\
\hline & Savings & 180 & 118 & -8 & -127 \\
\hline \multirow[t]{3}{*}{ CPP-2 } & Baseline & 3,715 & 1,352 & 293 & 4,667 \\
\hline & Actual Auto-DR Event & 3,678 & 1,311 & 276 & 4,397 \\
\hline & Savings & 37 & 41 & 17 & 271 \\
\hline \multirow[t]{3}{*}{ CPP-3 } & Baseline & 3,715 & 1,352 & 293 & 4,667 \\
\hline & Actual Auto-DR Event & 3,768 & 1,375 & 281 & 4,476 \\
\hline & Savings & -53 & -23 & 12 & 191 \\
\hline \multirow[t]{3}{*}{ CPP-4 } & Baseline & 3,225 & 1,201 & 244 & 3,887 \\
\hline & Actual Auto-DR Event & 3,127 & 1,128 & 224 & 3,568 \\
\hline & Savings & 98 & 73 & 20 & 319 \\
\hline \multirow[t]{3}{*}{ CPP-5 } & Baseline & 3,374 & 1,288 & 264 & 4,206 \\
\hline & Actual Auto-DR Event & 3,329 & 1,213 & 244 & 3,887 \\
\hline & Savings & 45 & 75 & 20 & 319 \\
\hline \multirow[t]{3}{*}{ CPP- 6} & Baseline & 3,374 & 1,288 & 264 & 4,206 \\
\hline & Actual Auto-DR Event & 3,398 & 1,243 & 240 & 3,823 \\
\hline & Savings & -24 & 45 & 24 & 382 \\
\hline \multirow[t]{3}{*}{ CPP-7 } & Baseline & 3,068 & 1,156 & 249 & 3,967 \\
\hline & Actual Auto-DR Event & 3,413 & 1,191 & 219 & 3,489 \\
\hline & Savings & -345 & -35 & 30 & 478 \\
\hline \multirow[t]{3}{*}{ CPP-8 } & Baseline & 3,068 & 1,156 & 249 & 3,967 \\
\hline & Actual Auto-DR Event & 3,156 & 1,153 & 223 & 3,552 \\
\hline & Savings & -88 & 3 & 26 & 414 \\
\hline \multirow[t]{3}{*}{ CPP-9 } & Baseline & 3,064 & 1,184 & 243 & 3,871 \\
\hline & Actual Auto-DR Event & 3,289 & 1,193 & 235 & 3,744 \\
\hline & Savings & -225 & -9 & 8 & 127 \\
\hline
\end{tabular}




\begin{tabular}{|c|c|c|c|c|c|}
\hline \multirow[b]{2}{*}{ DATE } & \multirow[b]{2}{*}{ I NDEX } & \multicolumn{2}{|c|}{ ENERGY } & \multicolumn{2}{|c|}{ DEMAND } \\
\hline & & $\begin{array}{r}\text { CONSUMPTION } \\
(\mathrm{KWH})\end{array}$ & $\begin{array}{r}\text { Charge } \\
(\$)\end{array}$ & $\begin{array}{r}\text { Max Demand } \\
\text { On PeAK } \\
(\mathrm{KW})\end{array}$ & $\begin{array}{r}\text { Demand } \\
\text { SAVI NGS (\$) }\end{array}$ \\
\hline \multirow[t]{3}{*}{ CPP- 10} & Baseline & 3,064 & 1,184 & 243 & 3,871 \\
\hline & Actual Auto-DR Event & 3,335 & 1,207 & 237 & 3,775 \\
\hline & Savings & -271 & -23 & 6 & 96 \\
\hline \multirow[t]{3}{*}{ CPP- 11} & Baseline & 3,537 & 1,348 & 267 & 4,253 \\
\hline & Actual Auto-DR Event & 3,563 & 1,326 & 260 & 4,142 \\
\hline & Savings & -26 & 22 & 7 & 112 \\
\hline \multicolumn{2}{|c|}{ Average Savings } & 293 & -105 & 19 & 281 \\
\hline
\end{tabular}




\section{Table D 13: Summary of Energy and Demand Savings for Auto-DR events - One} Carnegie Plaza

\begin{tabular}{|c|c|c|c|c|c|}
\hline \multirow[b]{2}{*}{ DATE } & \multirow[b]{2}{*}{ I NDEX } & \multicolumn{2}{|c|}{ ENERGY } & \multicolumn{2}{|c|}{ DEMAND } \\
\hline & & $\begin{array}{r}\text { CONSUMPTION } \\
(\mathrm{KWH})\end{array}$ & $\begin{array}{r}\text { CHARGE } \\
(\$)\end{array}$ & $\begin{array}{r}\text { MAX DEMAND } \\
\text { ON PEAK } \\
(\mathrm{kW})\end{array}$ & $\begin{array}{r}\text { Demand } \\
\text { SAVINGS (\$) }\end{array}$ \\
\hline \multirow[t]{3}{*}{ CPP-1 } & Baseline & 4,726 & 1,657 & 344 & 5,480 \\
\hline & Actual Auto-DR Event & 4,383 & 1,660 & 377 & 6,006 \\
\hline & Savings & 343 & -3 & -33 & -526 \\
\hline \multirow[t]{3}{*}{ CPP-2 } & Baseline & 4,726 & 1,657 & 344 & 5,480 \\
\hline & Actual Auto-DR Event & 4,484 & 1,663 & 363 & 5,783 \\
\hline & Savings & 242 & -6 & -19 & -303 \\
\hline \multirow[t]{3}{*}{ CPP-3 } & Baseline & 4,726 & 1,657 & 344 & 5,480 \\
\hline & Actual Auto-DR Event & 4,683 & 1,635 & 345 & 5,496 \\
\hline & Savings & 43 & 22 & -1 & -16 \\
\hline \multirow[t]{3}{*}{ CPP-4 } & Baseline & 5,480 & 1,317 & 345 & 5,496 \\
\hline & Actual Auto-DR Event & 4,235 & 1,184 & 356 & 5,671 \\
\hline & Savings & 1,245 & 133 & -11 & -175 \\
\hline \multirow[t]{3}{*}{ CPP-5 } & Baseline & 4,474 & 1,682 & 368 & 5,862 \\
\hline & Actual Auto-DR Event & 4,537 & 1,653 & 354 & 5,639 \\
\hline & Savings & -63 & 29 & 14 & 223 \\
\hline \multirow[t]{3}{*}{ СРP-6 } & Baseline & 4,474 & 1,682 & 368 & 5,862 \\
\hline & Actual Auto-DR Event & 4,400 & 1,651 & 368 & 5,862 \\
\hline & Savings & 74 & 31 & 0 & 0 \\
\hline \multirow[t]{3}{*}{ CPP- 7} & Baseline & 4,474 & 1,682 & 368 & 5,862 \\
\hline & Actual Auto-DR Event & 4,501 & 1,570 & 331 & 5,273 \\
\hline & Savings & -27 & 112 & 37 & 589 \\
\hline \multirow[t]{3}{*}{ CPP-8 } & Baseline & 4,474 & 1,682 & 368 & 5,862 \\
\hline & Actual Auto-DR Event & 4,112 & 1,557 & 355 & 5,655 \\
\hline & Savings & 362 & 125 & 13 & 207 \\
\hline \multirow[t]{3}{*}{ CPP-9 } & Baseline & 4,474 & 1,682 & 368 & 5,862 \\
\hline & Actual Auto-DR Event & 4,278 & 1,603 & 365 & 5,814 \\
\hline & Savings & 196 & 79 & 3 & 48 \\
\hline \multirow[t]{2}{*}{ CPP-10 } & Baseline & 4,474 & 1,682 & 368 & 5,862 \\
\hline & Actual Auto-DR Event & 4,404 & 1,644 & 364 & 5,799 \\
\hline
\end{tabular}




\begin{tabular}{|c|c|c|c|c|c|}
\hline \multirow[b]{2}{*}{ DATE } & \multirow[b]{2}{*}{ I NDEX } & \multicolumn{2}{|c|}{ ENERGY } & \multicolumn{2}{|c|}{ Demand } \\
\hline & & $\begin{array}{r}\text { CONSUMPTI ON } \\
(\text { (KW })\end{array}$ & $\begin{array}{r}\text { ChARGE } \\
(\$)\end{array}$ & $\begin{array}{r}\text { Max Demand } \\
\text { On PeAK } \\
(\mathrm{kW})\end{array}$ & $\begin{array}{r}\text { Demand } \\
\text { SaVings (\$) }\end{array}$ \\
\hline & Savings & 70 & 38 & 4 & 64 \\
\hline \multirow[t]{3}{*}{ CPP-11 } & Baseline & 4,932 & 1,777 & 362 & 5,767 \\
\hline & Actual Auto-DR Event & 4,416 & 1,646 & 349 & 5,560 \\
\hline & Savings & 516 & 131 & 13 & 207 \\
\hline \multicolumn{2}{|c|}{ Average Savings } & 293 & 206 & 62 & 992 \\
\hline
\end{tabular}




\section{Table D 14: Summary of Energy and Demand Savings for Auto-DR events - One}

Carnegie Plaza (small one)

\begin{tabular}{|c|c|c|c|c|c|}
\hline \multirow[b]{2}{*}{ DATE } & \multirow[b]{2}{*}{ I NDEX } & \multicolumn{2}{|c|}{ ENERGY } & \multicolumn{2}{|c|}{ Demand } \\
\hline & & $\begin{array}{r}\text { CoNSUMPTI ON } \\
(\mathrm{KWH})\end{array}$ & $\begin{array}{r}\text { Charge } \\
(\$)\end{array}$ & $\begin{array}{r}\text { Max Demand } \\
\text { ON PeAK } \\
(\mathrm{KW})\end{array}$ & $\begin{array}{r}\text { Demand } \\
\text { SaVings ( } \$ \text { ) }\end{array}$ \\
\hline \multirow[t]{3}{*}{ CPP- 1} & Baseline & 2,396 & 881 & 192 & 3,059 \\
\hline & Actual Auto-DR Event & 2,037 & 822 & 194 & 3,090 \\
\hline & Savings & 359 & 59 & -2 & -32 \\
\hline \multirow[t]{3}{*}{ CPP-2 } & Baseline & 2,396 & 881 & 192 & 3,059 \\
\hline & Actual Auto-DR Event & 2,181 & 875 & 218 & 3,473 \\
\hline & Savings & 215 & 6 & -26 & -414 \\
\hline \multirow[t]{3}{*}{ CPP-3 } & Baseline & 2,396 & 881 & 192 & 3,059 \\
\hline & Actual Auto-DR Event & 2,248 & 877 & 186 & 2,963 \\
\hline & Savings & 148 & 4 & 6 & 96 \\
\hline \multirow[t]{3}{*}{ CPP-4 } & Baseline & 2,997 & 1,026 & 210 & 3,345 \\
\hline & Actual Auto-DR Event & 2,074 & 783 & 196 & 3,122 \\
\hline & Savings & 923 & 243 & 14 & 223 \\
\hline \multirow[t]{3}{*}{ CPP-5 } & Baseline & 2,454 & 974 & 221 & 3,521 \\
\hline & Actual Auto-DR Event & 2,343 & 883 & 199 & 3,170 \\
\hline & Savings & 111 & 91 & 22 & 350 \\
\hline \multirow[t]{3}{*}{ CPP- 6} & Baseline & 2,454 & 974 & 221 & 3,521 \\
\hline & Actual Auto-DR Event & 2,324 & 890 & 199 & 3,170 \\
\hline & Savings & 130 & 84 & 22 & 350 \\
\hline \multirow[t]{3}{*}{ CPP- 7} & Baseline & 2,273 & 872 & 197 & 3,138 \\
\hline & Actual Auto-DR Event & 2,329 & 807 & 166 & 2,644 \\
\hline & Savings & -56 & 65 & 31 & 494 \\
\hline \multirow[t]{3}{*}{ CPP-8 } & Baseline & 2,273 & 872 & 197 & 3,138 \\
\hline & Actual Auto-DR Event & 1,932 & 748 & 162 & 2,581 \\
\hline & Savings & 341 & 124 & 35 & 558 \\
\hline \multirow[t]{3}{*}{ CPP-9 } & Baseline & 1,999 & 772 & 179 & 2,851 \\
\hline & Actual Auto-DR Event & 2,177 & 823 & 195 & 3,106 \\
\hline & Savings & -178 & -51 & -16 & -255 \\
\hline \multirow[t]{2}{*}{ CPP- 10} & Baseline & 1,999 & 772 & 179 & 2,851 \\
\hline & Actual Auto-DR Event & 2,198 & 813 & 180 & 2,867 \\
\hline
\end{tabular}




\begin{tabular}{|c|c|c|c|c|c|}
\hline \multirow[b]{2}{*}{ DATE } & \multirow[b]{2}{*}{ I NDEX } & \multicolumn{2}{|c|}{ ENERGY } & \multicolumn{2}{|c|}{ Demand } \\
\hline & & $\begin{array}{r}\text { CONSUMPTION } \\
(\text { KWH) }\end{array}$ & $\begin{array}{r}\text { Charge } \\
(\$)\end{array}$ & $\begin{array}{r}\text { Max Demand } \\
\text { On PeAK } \\
(\mathrm{kW})\end{array}$ & $\begin{array}{r}\text { Demand } \\
\text { SaVI NGS (\$) }\end{array}$ \\
\hline & Savings & -199 & -41 & -1 & -16 \\
\hline \multirow[t]{3}{*}{ CPP-11 } & Baseline & 2,249 & 887 & 202 & 3,218 \\
\hline & Actual Auto-DR Event & 2,347 & 899 & 188 & 2,995 \\
\hline & Savings & -98 & -12 & 14 & 223 \\
\hline \multicolumn{2}{|c|}{ Average Savings } & 122 & 63 & 15 & 315 \\
\hline
\end{tabular}




\section{Table D 15: Summary of Energy and Demand Savings for Auto-DR events - One}

VANDERBILT

\begin{tabular}{|c|c|c|c|c|c|}
\hline \multirow[b]{2}{*}{ DATE } & \multirow[b]{2}{*}{ I NDEX } & \multicolumn{2}{|c|}{ ENERGY } & \multicolumn{2}{|c|}{ DEMAND } \\
\hline & & $\begin{array}{r}\text { CONSUMPTION } \\
(\mathrm{KWH})\end{array}$ & $\begin{array}{r}\text { ChARGE } \\
(\$)\end{array}$ & $\begin{array}{r}\text { Max Demand } \\
\text { ON PEAK } \\
(\mathrm{KW})\end{array}$ & $\begin{array}{r}\text { Demand } \\
\text { SaVI NGS ( } \$ \text { ) }\end{array}$ \\
\hline \multirow[t]{3}{*}{ CPP-1 } & Baseline & 6,849 & 2,287 & 419 & 6,675 \\
\hline & Actual Auto-DR Event & 6,404 & 2,256 & 417 & 6,643 \\
\hline & Savings & 445 & 31 & 2 & 32 \\
\hline \multirow[t]{3}{*}{ CPP-2 } & Baseline & 6,849 & 2,287 & 419 & 6,675 \\
\hline & Actual Auto-DR Event & 6,380 & 2,247 & 420 & 6,691 \\
\hline & Savings & 469 & 40 & -1 & -16 \\
\hline \multirow[t]{3}{*}{ CPP-3 } & Baseline & 6,849 & 2,287 & 419 & 6,675 \\
\hline & Actual Auto-DR Event & 6,756 & 2,290 & 416 & 6,627 \\
\hline & Savings & 93 & -3 & 3 & 48 \\
\hline \multirow[t]{3}{*}{ CPP-4 } & Baseline & 7,550 & 2,464 & 435 & 6,930 \\
\hline & Actual Auto-DR Event & 6,109 & 2,175 & 404 & 6,436 \\
\hline & Savings & 1,441 & 289 & 31 & 494 \\
\hline \multirow[t]{3}{*}{ CPP-5 } & Baseline & 6,730 & 2,400 & 445 & 7,089 \\
\hline & Actual Auto-DR Event & 6,623 & 2,331 & 432 & 6,882 \\
\hline & Savings & 107 & 69 & 13 & 207 \\
\hline \multirow[t]{3}{*}{ CPP-6 } & Baseline & 6,730 & 2,400 & 445 & 7,089 \\
\hline & Actual Auto-DR Event & 6,525 & 2,332 & 431 & 6,866 \\
\hline & Savings & 205 & 68 & 14 & 223 \\
\hline \multirow[t]{3}{*}{ CPP- 7} & Baseline & 6,473 & 2,280 & 425 & 6,770 \\
\hline & Actual Auto-DR Event & 6,688 & 2,277 & 416 & 6,627 \\
\hline & Savings & -215 & 3 & 9 & 143 \\
\hline \multirow[t]{3}{*}{ CPP-8 } & Baseline & 6,473 & 2,280 & 425 & 6,770 \\
\hline & Actual Auto-DR Event & 6,055 & 2,200 & 415 & 6,611 \\
\hline & Savings & 418 & 80 & 10 & 159 \\
\hline \multirow[t]{3}{*}{ CPP-9 } & Baseline & 6,817 & 2,356 & 429 & 6,834 \\
\hline & Actual Auto-DR Event & 6,248 & 2,126 & 407 & 6,484 \\
\hline & Savings & 569 & 230 & 22 & 350 \\
\hline \multirow[t]{2}{*}{ CPP-10 } & Baseline & 6,817 & 2,356 & 429 & 6,834 \\
\hline & Actual Auto-DR Event & 6,191 & 2,187 & 408 & 6,499 \\
\hline
\end{tabular}




\begin{tabular}{|c|c|c|c|c|c|}
\hline \multirow[b]{2}{*}{ DATE } & \multirow[b]{2}{*}{ I NDEX } & \multicolumn{2}{|c|}{ ENERGY } & \multicolumn{2}{|c|}{ Demand } \\
\hline & & $\begin{array}{r}\text { CONSUMPTION } \\
(\text { KWH) }\end{array}$ & $\begin{array}{r}\text { Charge } \\
(\$)\end{array}$ & $\begin{array}{r}\text { Max Demand } \\
\text { On PeAK } \\
(\mathrm{kW})\end{array}$ & $\begin{array}{r}\text { Demand } \\
\text { SaVI NGS (\$) }\end{array}$ \\
\hline & Savings & 626 & 169 & 21 & 335 \\
\hline \multirow[t]{3}{*}{ CPP-11 } & Baseline & 5,575 & 1,992 & 365 & 5,814 \\
\hline & Actual Auto-DR Event & 5,704 & 2,013 & 367 & 5,846 \\
\hline & Savings & -129 & -21 & -2 & -32 \\
\hline \multicolumn{2}{|c|}{ Average Savings } & 378 & 111 & 15 & 315 \\
\hline
\end{tabular}




\section{Table D 16: Summary of Energy and Demand Savings for Auto-DR events - One} PARKSIDE

\begin{tabular}{|c|c|c|c|c|c|}
\hline \multirow[b]{2}{*}{ DATE } & \multirow[b]{2}{*}{ I NDEX } & \multicolumn{2}{|c|}{ ENERGY } & \multicolumn{2}{|c|}{ DEMAND } \\
\hline & & $\begin{array}{r}\text { CONSUMPTION } \\
(\mathrm{KWH})\end{array}$ & $\begin{array}{r}\text { CHARGE } \\
(\$)\end{array}$ & $\begin{array}{r}\text { MAX DEMAND } \\
\text { ON PEAK } \\
(\mathrm{kW})\end{array}$ & $\begin{array}{r}\text { Demand } \\
\text { SAVINGS (\$) }\end{array}$ \\
\hline \multirow[t]{3}{*}{ CPP-1 } & Baseline & 4,457 & 1,561 & 317 & 5,050 \\
\hline & Actual Auto-DR Event & 4,204 & 1,551 & 324 & 5,161 \\
\hline & Savings & 253 & 10 & -7 & -112 \\
\hline \multirow[t]{3}{*}{ CPP-2 } & Baseline & 4,457 & 1,561 & 317 & 5,050 \\
\hline & Actual Auto-DR Event & 4,250 & 1,562 & 327 & 5,209 \\
\hline & Savings & 207 & -1 & -10 & -159 \\
\hline \multirow[t]{3}{*}{ CPP-3 } & Baseline & 4,457 & 1,561 & 317 & 5,050 \\
\hline & Actual Auto-DR Event & 4,412 & 1,570 & 325 & 5,177 \\
\hline & Savings & 45 & -9 & -8 & -127 \\
\hline \multirow[t]{3}{*}{ CPP-4 } & Baseline & 4,044 & 1,485 & 303 & 4,827 \\
\hline & Actual Auto-DR Event & 4,247 & 1,516 & 308 & 4,906 \\
\hline & Savings & -203 & -31 & -5 & -80 \\
\hline \multirow[t]{3}{*}{ CPP-5 } & Baseline & 4,418 & 1,629 & 341 & 5,432 \\
\hline & Actual Auto-DR Event & 4,314 & 1,542 & 311 & 4,954 \\
\hline & Savings & 104 & 87 & 30 & 478 \\
\hline \multirow[t]{3}{*}{ СРP-6 } & Baseline & 4,418 & 1,629 & 341 & 5,432 \\
\hline & Actual Auto-DR Event & 4,240 & 1,548 & 324 & 5,161 \\
\hline & Savings & 178 & 81 & 17 & 271 \\
\hline \multirow[t]{3}{*}{ CPP- 7} & Baseline & 4,316 & 1,566 & 325 & 5,177 \\
\hline & Actual Auto-DR Event & 4,262 & 1,466 & 294 & 4,683 \\
\hline & Savings & 54 & 100 & 31 & 494 \\
\hline \multirow[t]{3}{*}{ CPP-8 } & Baseline & 4,316 & 1,566 & 325 & 5,177 \\
\hline & Actual Auto-DR Event & 4,001 & 1,441 & 293 & 4,667 \\
\hline & Savings & 315 & 125 & 32 & 510 \\
\hline \multirow[t]{3}{*}{ CPP-9 } & Baseline & 4,470 & 1,610 & 332 & 5,289 \\
\hline & Actual Auto-DR Event & 4,297 & 1,487 & 293 & 4,667 \\
\hline & Savings & 173 & 123 & 39 & 621 \\
\hline \multirow[t]{2}{*}{ CPP-10 } & Baseline & 4,470 & 1,610 & 332 & 5,289 \\
\hline & Actual Auto-DR Event & 4,201 & 1,502 & 293 & 4,667 \\
\hline
\end{tabular}




\begin{tabular}{|c|c|c|c|c|c|}
\hline \multirow[b]{2}{*}{ DATE } & \multirow[b]{2}{*}{ I NDEX } & \multicolumn{2}{|c|}{ ENERGY } & \multicolumn{2}{|c|}{ Demand } \\
\hline & & $\begin{array}{r}\text { CONSUMPTI ON } \\
(\text { (KW })\end{array}$ & $\begin{array}{r}\text { Charge } \\
(\$)\end{array}$ & $\begin{array}{r}\text { Max Demand } \\
\text { On PeAK } \\
(\mathrm{kW})\end{array}$ & $\begin{array}{r}\text { Demand } \\
\text { Savings (\$) }\end{array}$ \\
\hline & Savings & 269 & 108 & 39 & 621 \\
\hline \multirow[t]{3}{*}{ CPP-11 } & Baseline & 4,598 & 1,688 & 342 & 5,448 \\
\hline & Actual Auto-DR Event & 4,529 & 1,615 & 322 & 5,129 \\
\hline & Savings & 69 & 73 & 20 & 319 \\
\hline \multicolumn{2}{|c|}{ Average Savings } & 120 & 83 & 25 & 404 \\
\hline
\end{tabular}


Table D 17: Summary of Energy and Demand Savings for Auto-DR events - Lakeside TOWER

\begin{tabular}{|c|c|c|c|c|c|}
\hline \multirow[b]{2}{*}{ DATE } & \multirow[b]{2}{*}{ I NDEX } & \multicolumn{2}{|c|}{ ENERGY } & \multicolumn{2}{|c|}{ Demand } \\
\hline & & $\begin{array}{r}\text { CONSUMPTION } \\
(\mathrm{KWH})\end{array}$ & $\begin{array}{r}\text { CHARGE } \\
(\$)\end{array}$ & $\begin{array}{r}\text { Max Demand } \\
\text { ON PEAK } \\
(\mathrm{kW})\end{array}$ & $\begin{array}{r}\text { Demand } \\
\text { SaVings (\$) }\end{array}$ \\
\hline \multirow[t]{3}{*}{ CPP-1 } & Baseline & 6,775 & 2,303 & 474 & 7,285 \\
\hline & Actual Auto-DR Event & 6,562 & 2,240 & 560 & 8,607 \\
\hline & Savings & 213 & 63 & -86 & $-1,322$ \\
\hline \multirow[t]{3}{*}{ CPP-2 } & Baseline & 6,775 & 2,303 & 474 & 7,285 \\
\hline & Actual Auto-DR Event & 6,552 & 2,217 & 526 & 8,085 \\
\hline & Savings & 223 & 86 & -52 & -799 \\
\hline \multirow[t]{3}{*}{ CPP-3 } & Baseline & 6,775 & 2,303 & 474 & 7,285 \\
\hline & Actual Auto-DR Event & 7,005 & 2,337 & 483 & 7,424 \\
\hline & Savings & -230 & -34 & -9 & -138 \\
\hline \multirow[t]{3}{*}{ CPP-4 } & Baseline & 5,958 & 2,069 & 444 & 6,824 \\
\hline & Actual Auto-DR Event & 5,768 & 1,907 & 427 & 6,563 \\
\hline & Savings & 190 & 162 & 17 & 261 \\
\hline \multirow[t]{3}{*}{ CPP-5 } & Baseline & 7,452 & 2,540 & 517 & 7,946 \\
\hline & Actual Auto-DR Event & 6,367 & 2,005 & 506 & 7,777 \\
\hline & Savings & 1,085 & 535 & 11 & 169 \\
\hline \multirow[t]{3}{*}{ CPP-6 } & Baseline & 7,452 & 2,540 & 517 & 7,946 \\
\hline & Actual Auto-DR Event & 6,308 & 2,030 & 506 & 7,777 \\
\hline & Savings & 1,144 & 510 & 11 & 169 \\
\hline \multirow[t]{3}{*}{ CPP-7 } & Baseline & 6,860 & 2,318 & 495 & 7,608 \\
\hline & Actual Auto-DR Event & 5,964 & 1,859 & 520 & 7,992 \\
\hline & Savings & 896 & 459 & -25 & -384 \\
\hline \multirow[t]{3}{*}{ CPP-8 } & Baseline & 6,860 & 2,318 & 495 & 7,608 \\
\hline & Actual Auto-DR Event & 5,716 & 1,912 & 536 & 8,238 \\
\hline & Savings & 1,144 & 406 & -41 & -630 \\
\hline \multirow[t]{3}{*}{ CPP-9 } & Baseline & 7,452 & 2,540 & 517 & 7,946 \\
\hline & Actual Auto-DR Event & 6,086 & 1,957 & 531 & 8,161 \\
\hline & Savings & 1,366 & 583 & -14 & -215 \\
\hline \multirow[t]{2}{*}{ CPP-10 } & Baseline & 7,452 & 2,540 & 517 & 7,946 \\
\hline & Actual Auto-DR Event & 6,500 & 2,161 & 552 & 8,484 \\
\hline
\end{tabular}




\begin{tabular}{|c|c|c|c|c|c|}
\hline \multirow[b]{2}{*}{ DATE } & \multirow[b]{2}{*}{ I NDEX } & \multicolumn{2}{|c|}{ ENERGY } & \multicolumn{2}{|c|}{ DEMAND } \\
\hline & & $\begin{array}{r}\text { CONSUMPTI ON } \\
(\text { (KW })\end{array}$ & $\begin{array}{r}\text { ChARGE } \\
(\$)\end{array}$ & $\begin{array}{r}\text { Max Demand } \\
\text { On PeAK } \\
(\mathrm{kW})\end{array}$ & $\begin{array}{r}\text { Demand } \\
\text { SaVings (\$) }\end{array}$ \\
\hline & Savings & 952 & 379 & -35 & -538 \\
\hline \multirow[t]{3}{*}{ CPP-11 } & Baseline & 7,704 & 2,623 & 558 & 8,576 \\
\hline & Actual Auto-DR Event & 6,751 & 2,290 & 490 & 7,531 \\
\hline & Savings & 953 & 333 & 68 & 1,045 \\
\hline \multicolumn{2}{|c|}{ Average Savings } & 966 & 421 & -1 & -15 \\
\hline
\end{tabular}




\section{Table D 18: Summary of Energy and Demand Savings for Auto-DR events - Two}

PARKSIDE

\begin{tabular}{|c|c|c|c|c|c|}
\hline \multirow[b]{2}{*}{ DATE } & \multirow[b]{2}{*}{ I NDEX } & \multicolumn{2}{|c|}{ Energy } & \multicolumn{2}{|c|}{ DEMAND } \\
\hline & & $\begin{array}{r}\text { CONSUMPTION } \\
(\text { KWH })\end{array}$ & $\begin{array}{r}\text { CHARGE } \\
(\$)\end{array}$ & $\begin{array}{r}\text { MAX DEMAND } \\
\text { ON PEAK } \\
(\mathrm{kW})\end{array}$ & $\begin{array}{r}\text { Demand } \\
\text { Savings (\$) }\end{array}$ \\
\hline \multirow[t]{3}{*}{ CPP-1 } & Baseline & 4,730 & 1,765 & 399 & 6,356 \\
\hline & Actual Auto-DR Event & 4,218 & 1,616 & 360 & 5,735 \\
\hline & Savings & 512 & 149 & 39 & 621 \\
\hline \multirow[t]{3}{*}{ CPP-2 } & Baseline & 4,730 & 1,765 & 399 & 6,356 \\
\hline & Actual Auto-DR Event & 4,324 & 1,653 & 390 & 6,213 \\
\hline & Savings & 406 & 112 & 9 & 143 \\
\hline \multirow[t]{3}{*}{ CPP-3 } & Baseline & 4,730 & 1,765 & 399 & 6,356 \\
\hline & Actual Auto-DR Event & 4,731 & 1,762 & 402 & 6,404 \\
\hline & Savings & -1 & 3 & -3 & -48 \\
\hline \multirow[t]{3}{*}{ CPP-4 } & Baseline & 3,585 & 1,422 & 344 & 5,480 \\
\hline & Actual Auto-DR Event & 3,704 & 1,364 & 312 & 4,970 \\
\hline & Savings & -119 & 58 & 32 & 510 \\
\hline \multirow[t]{3}{*}{ CPP-5 } & Baseline & 4,518 & 1,829 & 412 & 6,563 \\
\hline & Actual Auto-DR Event & 4,190 & 1,520 & 347 & 5,528 \\
\hline & Savings & 328 & 309 & 65 & 1,035 \\
\hline \multirow[t]{3}{*}{ CPP- 6} & Baseline & 4,518 & 1,829 & 412 & 6,563 \\
\hline & Actual Auto-DR Event & 3,924 & 1,452 & 339 & 5,400 \\
\hline & Savings & 594 & 377 & 73 & 1,163 \\
\hline \multirow[t]{3}{*}{ CPP- 7} & Baseline & 4,229 & 1,630 & 392 & 6,245 \\
\hline & Actual Auto-DR Event & 4,232 & 1,524 & 339 & 5,400 \\
\hline & Savings & -3 & 106 & 53 & 844 \\
\hline \multirow[t]{3}{*}{ CPP-8 } & Baseline & 4,229 & 1,630 & 392 & 6,245 \\
\hline & Actual Auto-DR Event & 3,912 & 1,495 & 340 & 5,416 \\
\hline & Savings & 317 & 135 & 52 & 828 \\
\hline \multirow[t]{3}{*}{ CPP-9 } & Baseline & 3,637 & 1,396 & 299 & 4,763 \\
\hline & Actual Auto-DR Event & 4,238 & 1,531 & 337 & 5,368 \\
\hline & Savings & -601 & -135 & -38 & -605 \\
\hline \multirow[t]{2}{*}{ CPP-10 } & Baseline & 3,637 & 1,396 & 299 & 4,763 \\
\hline & Actual Auto-DR Event & 4,004 & 1,464 & 298 & 4,747 \\
\hline
\end{tabular}




\begin{tabular}{|c|c|c|c|c|c|}
\hline \multirow[b]{2}{*}{ DAte } & \multirow[b]{2}{*}{ I NDEX } & \multicolumn{2}{|c|}{ ENERGY } & \multicolumn{2}{|c|}{ Demand } \\
\hline & & $\begin{array}{r}\text { CONSUMPTI ON } \\
(\text { (KW })\end{array}$ & $\begin{array}{r}\text { ChARGE } \\
(\$)\end{array}$ & $\begin{array}{r}\text { Max Demand } \\
\text { On PeAK } \\
(\mathrm{kW})\end{array}$ & $\begin{array}{r}\text { Demand } \\
\text { SAVINGS (\$) }\end{array}$ \\
\hline & Savings & -367 & -68 & 1 & 16 \\
\hline \multirow[t]{3}{*}{ CPP-11 } & Baseline & 4,930 & 1,849 & 417 & 6,643 \\
\hline & Actual Auto-DR Event & 4,164 & 1,531 & 356 & 5,671 \\
\hline & Savings & 766 & 318 & 61 & 972 \\
\hline \multicolumn{2}{|c|}{ Average Savings } & 114 & 138 & 37 & 595 \\
\hline
\end{tabular}


Table D 19: Summary of Energy and Demand Savings for Auto-DR events - Three Carnegie Plaza

\begin{tabular}{|c|c|c|c|c|c|}
\hline \multirow[b]{2}{*}{ DATE } & \multirow[b]{2}{*}{ I NDEX } & \multicolumn{2}{|c|}{ ENERGY } & \multicolumn{2}{|c|}{ Demand } \\
\hline & & $\begin{array}{r}\text { CONSUMPTION } \\
(\text { KWH })\end{array}$ & $\begin{array}{r}\text { CHARGE } \\
(\$)\end{array}$ & $\begin{array}{r}\text { MAX DEMAND } \\
\text { ON PEAK } \\
(\mathrm{kW})\end{array}$ & $\begin{array}{r}\text { DEMAND } \\
\text { SAVI NGS ( } \$ \text { ) }\end{array}$ \\
\hline \multirow[t]{3}{*}{ CPP- 1} & Baseline & 3,228 & 1,113 & 239 & 3,807 \\
\hline & Actual Auto-DR Event & 3,003 & 1,139 & 348 & 5,544 \\
\hline & Savings & 225 & -26 & -109 & $-1,736$ \\
\hline \multirow[t]{3}{*}{ CPP-2 } & Baseline & 3,228 & 1,113 & 239 & 3,807 \\
\hline & Actual Auto-DR Event & 2,997 & 1,094 & 276 & 4,397 \\
\hline & Savings & 231 & 19 & -37 & -589 \\
\hline \multirow[t]{3}{*}{ CPP-3 } & Baseline & 3,228 & 1,113 & 239 & 3,807 \\
\hline & Actual Auto-DR Event & 3,468 & 1,208 & 252 & 4,014 \\
\hline & Savings & -240 & -95 & -13 & -207 \\
\hline \multirow[t]{3}{*}{ CPP-4 } & Baseline & 2,909 & 1,096 & 239 & 3,807 \\
\hline & Actual Auto-DR Event & 2,715 & 905 & 172 & 2,740 \\
\hline & Savings & 194 & 191 & 67 & 1,067 \\
\hline \multirow[t]{3}{*}{ CPP-5 } & Baseline & 3,250 & 1,199 & 254 & 4,046 \\
\hline & Actual Auto-DR Event & 3,009 & 994 & 189 & 3,011 \\
\hline & Savings & 241 & 205 & 65 & 1,035 \\
\hline \multirow[t]{3}{*}{ CPP-6 } & Baseline & 3,250 & 1,199 & 254 & 4,046 \\
\hline & Actual Auto-DR Event & 3,030 & 1,020 & 192 & 3,059 \\
\hline & Savings & 220 & 179 & 62 & 988 \\
\hline \multirow[t]{3}{*}{ CPP-7 } & Baseline & 3,822 & 1,417 & 311 & 4,954 \\
\hline & Actual Auto-DR Event & 3,343 & 1,136 & 228 & 3,632 \\
\hline & Savings & 479 & 281 & 83 & 1,322 \\
\hline \multirow[t]{3}{*}{ CPP-8 } & Baseline & 3,822 & 1,417 & 311 & 4,954 \\
\hline & Actual Auto-DR Event & 3,280 & 1,190 & 254 & 4,046 \\
\hline & Savings & 542 & 227 & 57 & 908 \\
\hline \multirow[t]{3}{*}{ CPP-9 } & Baseline & 3,643 & 1,386 & 294 & 4,683 \\
\hline & Actual Auto-DR Event & 3,272 & 1,142 & 228 & 3,632 \\
\hline & Savings & 371 & 244 & 66 & 1,051 \\
\hline \multirow[t]{2}{*}{ CPP-10 } & Baseline & 3,643 & 1,386 & 294 & 4,683 \\
\hline & Actual Auto-DR Event & 3,415 & 1,199 & 248 & 3,951 \\
\hline
\end{tabular}




\begin{tabular}{|c|c|c|c|c|c|}
\hline \multirow[b]{2}{*}{ DATE } & \multirow[b]{2}{*}{ I NDEX } & \multicolumn{2}{|c|}{ ENERGY } & \multicolumn{2}{|c|}{ Demand } \\
\hline & & $\begin{array}{r}\text { CONSUMPTION } \\
(\text { KW }\end{array}$ & $\begin{array}{r}\text { ChARGE } \\
\text { (\$) }\end{array}$ & $\begin{array}{r}\text { Max Demand } \\
\text { ON PeAK } \\
(\mathrm{KW})\end{array}$ & $\begin{array}{r}\text { Demand } \\
\text { SAVINGS (\$) }\end{array}$ \\
\hline & Savings & 228 & 187 & 46 & 733 \\
\hline \multirow[t]{3}{*}{ CPP-11 } & Baseline & 3,515 & 1,312 & 280 & 4,460 \\
\hline & Actual Auto-DR Event & 3,450 & 1,175 & 228 & 3,632 \\
\hline & Savings & 65 & 137 & 52 & 828 \\
\hline \multicolumn{2}{|c|}{ Average Savings } & 293 & 206 & 62 & 992 \\
\hline
\end{tabular}




\section{Table D 20: Summary of Energy and Demand Savings for Auto-DR events - Brier} Corporate Center

\begin{tabular}{|c|c|c|c|c|c|}
\hline \multirow[b]{2}{*}{ DATE } & \multirow[b]{2}{*}{ I NDEX } & \multicolumn{2}{|c|}{ ENERGY } & \multicolumn{2}{|c|}{ Demand } \\
\hline & & $\begin{array}{r}\text { CONSUMPTION } \\
(\mathrm{KWH})\end{array}$ & $\begin{array}{r}\text { Charge } \\
(\$)\end{array}$ & $\begin{array}{r}\text { MAX DEMAND } \\
\text { ON PEAK } \\
(\mathrm{KW})\end{array}$ & $\begin{array}{r}\text { Demand } \\
\text { Savings ( \$) }\end{array}$ \\
\hline \multirow[t]{3}{*}{ CPP-1 } & Baseline & 6,626 & 2,238 & 430 & 6,850 \\
\hline & Actual Auto-DR Event & 6,803 & 2,386 & 494 & 7,869 \\
\hline & Savings & -177 & -148 & -64 & $-1,020$ \\
\hline \multirow[t]{3}{*}{ CPP-2 } & Baseline & 6,626 & 2,238 & 430 & 6,850 \\
\hline & Actual Auto-DR Event & 6,786 & 2,322 & 418 & 6,659 \\
\hline & Savings & -160 & -84 & 12 & 191 \\
\hline \multirow[t]{3}{*}{ CPP-3 } & Baseline & 6,626 & 2,238 & 430 & 6,850 \\
\hline & Actual Auto-DR Event & 6,742 & 2,326 & 422 & 6,722 \\
\hline & Savings & -116 & -88 & 8 & 127 \\
\hline \multirow[t]{3}{*}{ CPP-4 } & Baseline & 6,497 & 2,241 & 406 & 6,468 \\
\hline & Actual Auto-DR Event & 6,473 & 2,192 & 391 & 6,229 \\
\hline & Savings & 24 & 49 & 15 & 239 \\
\hline \multirow[t]{3}{*}{ CPP-5 } & Baseline & 7,226 & 2,549 & 470 & 7,487 \\
\hline & Actual Auto-DR Event & 6,817 & 2,278 & 413 & 6,579 \\
\hline & Savings & 409 & 271 & 57 & 908 \\
\hline \multirow[t]{3}{*}{ CPP- 6} & Baseline & 7,226 & 2,549 & 470 & 7,487 \\
\hline & Actual Auto-DR Event & 6,907 & 2,327 & 422 & 6,722 \\
\hline & Savings & 319 & 222 & 48 & 765 \\
\hline \multirow[t]{3}{*}{ CPP-7 } & Baseline & 6,949 & 2,373 & 451 & 7,184 \\
\hline & Actual Auto-DR Event & 6,704 & 2,232 & 401 & 6,388 \\
\hline & Savings & 245 & 141 & 50 & 797 \\
\hline \multirow[t]{3}{*}{ CPP-8 } & Baseline & 6,949 & 2,373 & 451 & 7,184 \\
\hline & Actual Auto-DR Event & 6,682 & 2,258 & 413 & 6,579 \\
\hline & Savings & 267 & 115 & 38 & 605 \\
\hline \multirow[t]{3}{*}{ CPP-9 } & Baseline & 6,673 & 2,292 & 425 & 6,770 \\
\hline & Actual Auto-DR Event & 6,894 & 2,310 & 418 & 6,659 \\
\hline & Savings & -221 & -18 & 7 & 112 \\
\hline \multirow[t]{2}{*}{ CPP-10 } & Baseline & 6,673 & 2,292 & 425 & 6,770 \\
\hline & Actual Auto-DR Event & 7,027 & 2,351 & 427 & 6,802 \\
\hline
\end{tabular}




\begin{tabular}{|c|c|c|c|c|c|}
\hline \multirow[b]{2}{*}{ DATE } & \multirow[b]{2}{*}{ I NDEX } & \multicolumn{2}{|c|}{ ENERGY } & \multicolumn{2}{|c|}{ DEMAND } \\
\hline & & $\begin{array}{r}\text { CONSUMPTION } \\
(\mathrm{KWH})\end{array}$ & $\begin{array}{r}\text { Charge } \\
(\$)\end{array}$ & $\begin{array}{r}\text { Max Demand } \\
\text { ON PeAK } \\
(k W)\end{array}$ & $\begin{array}{r}\text { Demand } \\
\text { SaVings (\$) }\end{array}$ \\
\hline & Savings & -354 & -59 & -2 & -32 \\
\hline \multirow[t]{3}{*}{ CPP-11 } & Baseline & 7,154 & 2,519 & 473 & 7,535 \\
\hline & Actual Auto-DR Event & 7,131 & 2,425 & 442 & 7,041 \\
\hline & Savings & 23 & 94 & 31 & 494 \\
\hline \multicolumn{2}{|c|}{ Average Savings } & 89 & 102 & 31 & 486 \\
\hline
\end{tabular}


Table D 21: Summary of Energy and Demand Savings for Auto-DR events - Vanderbilt Plaza

\begin{tabular}{|c|c|c|c|c|c|}
\hline \multirow[b]{2}{*}{ DATE } & \multirow[b]{2}{*}{ I NDEX } & \multicolumn{2}{|c|}{ ENERGY } & \multicolumn{2}{|c|}{ DEMAND } \\
\hline & & $\begin{array}{r}\text { CONSUMPTION } \\
(\mathrm{KWH})\end{array}$ & $\begin{array}{r}\text { CHARGE } \\
(\$)\end{array}$ & $\begin{array}{r}\text { MAX DEMAND } \\
\text { ON PEAK } \\
(\mathrm{kW})\end{array}$ & $\begin{array}{r}\text { Demand } \\
\text { SAVINGS (\$) }\end{array}$ \\
\hline \multirow[t]{3}{*}{ CPP- 1} & Baseline & 8,160 & 2,818 & 563 & 8,969 \\
\hline & Actual Auto-DR Event & 6,583 & 2,459 & 492 & 7,838 \\
\hline & Savings & 1,577 & 359 & 71 & 1,131 \\
\hline \multirow[t]{3}{*}{ CPP-2 } & Baseline & 8,160 & 2,818 & 563 & 8,969 \\
\hline & Actual Auto-DR Event & 6,324 & 2,292 & 442 & 7,041 \\
\hline & Savings & 1,836 & 526 & 121 & 1,928 \\
\hline \multirow[t]{3}{*}{ CPP-3 } & Baseline & 8,160 & 2,818 & 563 & 8,969 \\
\hline & Actual Auto-DR Event & 7,611 & 2,657 & 495 & 7,885 \\
\hline & Savings & 549 & 161 & 68 & 1,083 \\
\hline \multirow[t]{3}{*}{ CPP-4 } & Baseline & 5,882 & 2,213 & 439 & 6,993 \\
\hline & Actual Auto-DR Event & 5,675 & 2,006 & 399 & 6,356 \\
\hline & Savings & 207 & 207 & 40 & 637 \\
\hline \multirow[t]{3}{*}{ CPP-5 } & Baseline & 6,891 & 2,614 & 524 & 8,347 \\
\hline & Actual Auto-DR Event & 6,402 & 2,154 & 433 & 6,898 \\
\hline & Savings & 489 & 460 & 91 & 1,450 \\
\hline \multirow[t]{3}{*}{ СРP-6 } & Baseline & 6,891 & 2,614 & 524 & 8,347 \\
\hline & Actual Auto-DR Event & 6,346 & 2,187 & 431 & 6,866 \\
\hline & Savings & 545 & 427 & 93 & 1,481 \\
\hline \multirow[t]{3}{*}{ CPP- 7} & Baseline & 5,925 & 2,182 & 438 & 6,977 \\
\hline & Actual Auto-DR Event & 6,925 & 2,264 & 436 & 6,945 \\
\hline & Savings & $-1,000$ & -82 & 2 & 32 \\
\hline \multirow[t]{3}{*}{ CPP-8 } & Baseline & 5,925 & 2,182 & 438 & 6,977 \\
\hline & Actual Auto-DR Event & 6,286 & 2,111 & 521 & 8,300 \\
\hline & Savings & -361 & 71 & -83 & $-1,322$ \\
\hline \multirow[t]{3}{*}{ CPP-9 } & Baseline & 6,055 & 2,188 & 433 & 6,898 \\
\hline & Actual Auto-DR Event & 6,353 & 2,127 & 400 & 6,372 \\
\hline & Savings & -298 & 61 & 33 & 526 \\
\hline \multirow[t]{2}{*}{ CPP-10 } & Baseline & 6,055 & 2,188 & 433 & 6,898 \\
\hline & Actual Auto-DR Event & 6,289 & 2,144 & 508 & 8,092 \\
\hline
\end{tabular}




\begin{tabular}{|c|c|c|c|c|c|}
\hline \multirow[b]{2}{*}{ DATE } & \multirow[b]{2}{*}{ I NDEX } & \multicolumn{2}{|c|}{ ENERGY } & \multicolumn{2}{|c|}{ DEMAND } \\
\hline & & $\begin{array}{r}\text { CONSUMPTION } \\
(\text { KWH) }\end{array}$ & $\begin{array}{r}\text { ChARGE } \\
(\$)\end{array}$ & $\begin{array}{r}\text { Max Demand } \\
\text { On PeAK } \\
(\mathrm{kW})\end{array}$ & $\begin{array}{r}\text { Demand } \\
\text { SaVI NGS (\$) }\end{array}$ \\
\hline & Savings & -234 & 44 & -75 & $-1,195$ \\
\hline \multirow[t]{3}{*}{ CPP-11 } & Baseline & 6,033 & 2,251 & 456 & 7,264 \\
\hline & Actual Auto-DR Event & 6,427 & 2,177 & 402 & 6,404 \\
\hline & Savings & -394 & 74 & 54 & 860 \\
\hline \multicolumn{2}{|c|}{ Average Savings } & -131 & 158 & 19 & 309 \\
\hline
\end{tabular}


Table D 22: Summary of Energy and Demand Savings for Auto-DR events - InLand Regional Center

\begin{tabular}{|c|c|c|c|c|c|}
\hline \multirow[b]{2}{*}{ DATE } & \multirow[b]{2}{*}{ I NDEX } & \multicolumn{2}{|c|}{ ENERGY } & \multicolumn{2}{|c|}{ Demand } \\
\hline & & $\begin{array}{r}\text { CONSUMPTI ON } \\
\left(\mathrm{KW}_{\mathrm{H}}\right)\end{array}$ & $\begin{array}{r}\text { ChARGE } \\
(\$)\end{array}$ & $\begin{array}{r}\text { MAX DEMAND } \\
\text { ON PEAK } \\
(\mathrm{kW})\end{array}$ & $\begin{array}{r}\text { Demand } \\
\text { SaVI NGS (\$) }\end{array}$ \\
\hline \multirow[t]{3}{*}{ CPP-1 } & Baseline & 5,121 & 1,918 & 420 & 6,691 \\
\hline & Actual Auto-DR Event & 4,566 & 1,903 & 492 & 7,838 \\
\hline & Savings & 555 & 15 & -72 & $-1,147$ \\
\hline \multirow[t]{3}{*}{ CPP-2 } & Baseline & 5,121 & 1,918 & 420 & 6,691 \\
\hline & Actual Auto-DR Event & 4,607 & 1,877 & 509 & 8,108 \\
\hline & Savings & 514 & 41 & -89 & $-1,418$ \\
\hline \multirow[t]{3}{*}{ CPP-3 } & Baseline & 5,121 & 1,918 & 420 & 6,691 \\
\hline & Actual Auto-DR Event & 4,962 & 1,914 & 440 & 7,009 \\
\hline & Savings & 159 & 4 & -20 & -319 \\
\hline \multirow[t]{3}{*}{ CPP-4 } & Baseline & 4,656 & 1,832 & 399 & 6,356 \\
\hline & Actual Auto-DR Event & 4,027 & 1,492 & 322 & 5,129 \\
\hline & Savings & 629 & 340 & 77 & 1,227 \\
\hline \multirow[t]{3}{*}{ CPP-5 } & Baseline & 5,137 & 2,061 & 471 & 7,503 \\
\hline & Actual Auto-DR Event & 4,608 & 1,655 & 351 & 5,591 \\
\hline & Savings & 529 & 406 & 120 & 1,912 \\
\hline \multirow[t]{3}{*}{ CPP-6 } & Baseline & 6,891 & 2,614 & 524 & 8,347 \\
\hline & Actual Auto-DR Event & 4,703 & 1,799 & 387 & 6,165 \\
\hline & Savings & 2,188 & 815 & 137 & 2,182 \\
\hline \multirow[t]{3}{*}{ CPP-7 } & Baseline & 4,492 & 1,747 & 377 & 6,006 \\
\hline & Actual Auto-DR Event & 4,859 & 1,882 & 403 & 6,420 \\
\hline & Savings & -367 & -135 & -26 & -414 \\
\hline \multirow[t]{3}{*}{ CPP-8 } & Baseline & 4,492 & 1,747 & 377 & 6,006 \\
\hline & Actual Auto-DR Event & 4,581 & 1,849 & 418 & 6,659 \\
\hline & Savings & -89 & -102 & -41 & -653 \\
\hline \multirow[t]{3}{*}{ CPP-9 } & Baseline & 4,318 & 1,702 & 372 & 5,926 \\
\hline & Actual Auto-DR Event & 4,454 & 1,649 & 357 & 5,687 \\
\hline & Savings & -136 & 53 & 15 & 239 \\
\hline \multirow[t]{2}{*}{ CPP-10 } & Baseline & 4,318 & 1,702 & 372 & 5,926 \\
\hline & Actual Auto-DR Event & 4,565 & 1,687 & 355 & 5,655 \\
\hline
\end{tabular}




\begin{tabular}{|c|c|c|c|c|c|}
\hline \multirow[b]{2}{*}{ DATE } & \multirow[b]{2}{*}{ I NDEX } & \multicolumn{2}{|c|}{ ENERGY } & \multicolumn{2}{|c|}{ Demand } \\
\hline & & $\begin{array}{r}\text { CONSUMPTION } \\
(\text { KWH) }\end{array}$ & $\begin{array}{r}\text { Charge } \\
(\$)\end{array}$ & $\begin{array}{r}\text { Max Demand } \\
\text { On PeAK } \\
(\mathrm{kW})\end{array}$ & $\begin{array}{r}\text { Demand } \\
\text { SaVI NGS (\$) }\end{array}$ \\
\hline & Savings & -247 & 15 & 17 & 271 \\
\hline \multirow[t]{3}{*}{ CPP-11 } & Baseline & 5,097 & 2,061 & 501 & 7,981 \\
\hline & Actual Auto-DR Event & 4,683 & 1,742 & 385 & 6,133 \\
\hline & Savings & 414 & 319 & 116 & 1,848 \\
\hline \multicolumn{2}{|c|}{ Average Savings } & 365 & 214 & 52 & 826 \\
\hline
\end{tabular}




\section{APPENDIX E- SimULATION RESULTS OF RECAUBRATED MODE}

\section{Table E 1: Simulation Results of Recalibrated Model on CPP Days - Two Carnegie Plaza}

\begin{tabular}{|c|c|c|c|c|c|c|c|}
\hline \multirow[t]{2}{*}{ DATE } & \multirow{2}{*}{ Period } & \multicolumn{2}{|c|}{$\mathbf{k W}$} & \multicolumn{2}{|c|}{$\mathrm{W} / \mathrm{FT}^{2}$} & \multicolumn{2}{|c|}{ WBP\% } \\
\hline & & MaX & Ave & Max & Ave & MaX & Ave \\
\hline \multirow[t]{2}{*}{ CPP- 1} & Moderate Price (12 pm-3 pm) & 66.2 & 37.0 & 0.96 & 0.54 & $25 \%$ & $14 \%$ \\
\hline & High Price ( 3 pm- 6 pm) & 62.9 & 33.0 & 0.91 & 0.48 & $24 \%$ & $13 \%$ \\
\hline \multirow[t]{2}{*}{ CPP-2 } & Moderate Price (12 pm-3 pm) & 55.5 & 31.2 & 0.81 & 0.45 & $24 \%$ & $13 \%$ \\
\hline & High Price ( 3 pm-6 pm) & 55.8 & 30.3 & 0.81 & 0.44 & $24 \%$ & $13 \%$ \\
\hline \multirow[t]{2}{*}{ CPP-3 } & Moderate Price (12 pm-3 pm) & 82.6 & 41.3 & 1.20 & 0.60 & $30 \%$ & $15 \%$ \\
\hline & High Price ( 3 pm-6 pm) & 71.6 & 41.0 & 1.04 & 0.59 & $26 \%$ & $15 \%$ \\
\hline \multirow[t]{2}{*}{ CPP-4 } & Moderate Price ( $12 \mathrm{pm}-3 \mathrm{pm}$ ) & 82.7 & 42.5 & 1.20 & 0.62 & $29 \%$ & $15 \%$ \\
\hline & High Price ( 3 pm- 6 pm) & 78.2 & 42.9 & 1.13 & 0.62 & $27 \%$ & $15 \%$ \\
\hline \multirow[t]{2}{*}{ CPP-5 } & Moderate Price (12 pm-3 pm) & 113.1 & 54.2 & 1.64 & 0.79 & $36 \%$ & $17 \%$ \\
\hline & High Price ( 3 pm- 6 pm) & 89.7 & 44.5 & 1.30 & 0.65 & $28 \%$ & $14 \%$ \\
\hline \multirow[t]{2}{*}{ CPP-6 } & Moderate Price (12 pm-3 pm) & 111.9 & 50.8 & 1.62 & 0.74 & $38 \%$ & $17 \%$ \\
\hline & High Price ( 3 pm- 6 pm) & 76.2 & 38.8 & 1.10 & 0.56 & $26 \%$ & $13 \%$ \\
\hline \multirow[t]{2}{*}{ CPP-7 } & Moderate Price (12 pm-3 pm) & 113.2 & 47.1 & 1.64 & 0.68 & $36 \%$ & $15 \%$ \\
\hline & High Price ( 3 pm- 6 pm) & 82.0 & 42.5 & 1.19 & 0.62 & $26 \%$ & $14 \%$ \\
\hline \multirow[t]{2}{*}{ CPP-8 } & Moderate Price (12 pm-3 pm) & 111.5 & 47.0 & 1.62 & 0.68 & $37 \%$ & $16 \%$ \\
\hline & High Price ( 3 pm-6 pm) & 79.9 & 42.0 & 1.16 & 0.61 & $27 \%$ & $14 \%$ \\
\hline \multirow[t]{2}{*}{ CPP-9 } & Moderate Price (12 pm-3 pm) & 81.2 & 38.7 & 1.18 & 0.56 & $31 \%$ & $15 \%$ \\
\hline & High Price ( 3 pm-6 pm) & 79.9 & 37.0 & 1.16 & 0.54 & $30 \%$ & $14 \%$ \\
\hline \multirow[t]{2}{*}{ CPP-10 } & Moderate Price ( 12 pm-3 pm) & 85.2 & 42.0 & 1.24 & 0.61 & $32 \%$ & $16 \%$ \\
\hline & High Price ( 3 pm- 6 pm) & 70.5 & 35.9 & 1.02 & 0.52 & $27 \%$ & $14 \%$ \\
\hline \multirow[t]{2}{*}{ CPP-11 } & Moderate Price (12 pm-3 pm) & 80.4 & 41.0 & 1.17 & 0.59 & $30 \%$ & $15 \%$ \\
\hline & High Price ( 3 pm- 6 pm) & 69.9 & 36.1 & 1.01 & 0.52 & $26 \%$ & $13 \%$ \\
\hline \multirow[t]{2}{*}{ CPP-12 } & Moderate Price ( 12 pm-3 pm) & 76.5 & 39.4 & 1.11 & 0.57 & $30 \%$ & $15 \%$ \\
\hline & High Price ( 3 pm- 6 pm) & 61.2 & 31.3 & 0.89 & 0.45 & $24 \%$ & $12 \%$ \\
\hline ge & Peak Period ( 12 pm-3 pm) & 80.7 & 40.3 & 1.17 & 0.58 & $29 \%$ & $14 \%$ \\
\hline
\end{tabular}




\section{Table E 2: Simulation Results of Recalibrated Model on CPP Days - One Carnegie}

\section{Plaza}

\begin{tabular}{|c|c|c|c|c|c|c|c|}
\hline \multirow[t]{2}{*}{ DATE } & \multirow[t]{2}{*}{ Period } & \multicolumn{2}{|c|}{$\mathbf{k W}$} & \multicolumn{2}{|c|}{$\mathbf{W} / \mathrm{FT}^{2}$} & \multicolumn{2}{|c|}{ WBP\% } \\
\hline & & MAX & Ave & MAX & Ave & MaX & Ave \\
\hline \multirow[t]{2}{*}{ CPP-1 } & Moderate Price (12 pm-3 pm) & 78.6 & 37.2 & 1.25 & 0.59 & $25 \%$ & $12 \%$ \\
\hline & High Price ( 3 pm- 6 pm) & 59.9 & 30.1 & 0.95 & 0.48 & $19 \%$ & $10 \%$ \\
\hline \multirow[t]{2}{*}{ CPP-2 } & Moderate Price (12 pm-3 pm) & 69.5 & 32.7 & 1.11 & 0.52 & $24 \%$ & $11 \%$ \\
\hline & High Price ( 3 pm- 6 pm) & 54.3 & 27.5 & 0.86 & 0.44 & $19 \%$ & $10 \%$ \\
\hline \multirow[t]{2}{*}{ CPP-3 } & Moderate Price (12 pm-3 pm) & 93.8 & 40.9 & 1.49 & 0.65 & $29 \%$ & $12 \%$ \\
\hline & High Price ( 3 pm- 6 pm) & 67.3 & 36.6 & 1.07 & 0.58 & $21 \%$ & $11 \%$ \\
\hline \multirow[t]{2}{*}{ CPP- 4} & Moderate Price (12 pm-3 pm) & 95.8 & 42.4 & 1.52 & 0.68 & $28 \%$ & $13 \%$ \\
\hline & High Price ( 3 pm- 6 pm) & 74.4 & 38.8 & 1.19 & 0.62 & $22 \%$ & $11 \%$ \\
\hline \multirow[t]{2}{*}{ CPP-5 } & Moderate Price ( $12 \mathrm{pm}-3 \mathrm{pm})$ & 125.8 & 53.7 & 2.00 & 0.85 & $34 \%$ & $15 \%$ \\
\hline & High Price ( 3 pm- $6 \mathrm{pm})$ & 84.2 & 40.1 & 1.34 & 0.64 & $23 \%$ & $11 \%$ \\
\hline \multirow[t]{2}{*}{ CPP- 6} & Moderate Price (12 pm-3 pm) & 124.7 & 50.5 & 1.99 & 0.80 & $35 \%$ & $14 \%$ \\
\hline & High Price ( 3 pm- $6 \mathrm{pm})$ & 71.8 & 35.1 & 1.14 & 0.56 & $20 \%$ & $10 \%$ \\
\hline \multirow[t]{2}{*}{ CPP- 7} & Moderate Price (12 pm-3 pm) & 120.2 & 47.9 & 1.91 & 0.76 & $33 \%$ & $13 \%$ \\
\hline & High Price ( 3 pm- 6 pm) & 77.0 & 38.9 & 1.23 & 0.62 & $21 \%$ & $11 \%$ \\
\hline \multirow[t]{2}{*}{ CPP-8 } & Moderate Price (12 pm-3 pm) & 116.6 & 46.9 & 1.86 & 0.75 & $33 \%$ & $13 \%$ \\
\hline & High Price ( 3 pm-6 pm) & 75.2 & 38.2 & 1.20 & 0.61 & $21 \%$ & $11 \%$ \\
\hline \multirow[t]{2}{*}{ CPP-9 } & Moderate Price (12 pm-3 pm) & 93.1 & 38.7 & 1.48 & 0.62 & $30 \%$ & $12 \%$ \\
\hline & High Price ( 3 pm- 6 pm) & 75.2 & 33.6 & 1.20 & 0.54 & $24 \%$ & $11 \%$ \\
\hline \multirow[t]{2}{*}{ CPP-10 } & Moderate Price ( $12 \mathrm{pm}-3 \mathrm{pm})$ & 98.7 & 42.2 & 1.57 & 0.67 & $31 \%$ & $13 \%$ \\
\hline & High Price ( 3 pm-6 pm) & 68.1 & 33.3 & 1.09 & 0.53 & $21 \%$ & $10 \%$ \\
\hline \multirow[t]{2}{*}{ CPP-11 } & Moderate Price ( $12 \mathrm{pm}-3 \mathrm{pm})$ & 92.4 & 41.0 & 1.47 & 0.65 & $28 \%$ & $13 \%$ \\
\hline & High Price ( 3 pm- 6 pm) & 67.0 & 32.9 & 1.07 & 0.52 & $20 \%$ & $10 \%$ \\
\hline \multirow[t]{2}{*}{ CPP-12 } & Moderate Price ( $12 \mathrm{pm}-3 \mathrm{pm})$ & 88.5 & 39.5 & 1.41 & 0.63 & $28 \%$ & $13 \%$ \\
\hline & High Price ( 3 pm- 6 pm) & 58.5 & 28.8 & 0.93 & 0.46 & $19 \%$ & $9 \%$ \\
\hline Average & Peak Period (12 pm-3 pm) & 84.6 & 38.7 & 1.35 & 0.62 & $25 \%$ & $12 \%$ \\
\hline
\end{tabular}




\section{Table E 3: Simulation Results of Regalibrated Model on CPP Days - One Carnegie}

\section{Plaza (building)}

\begin{tabular}{|c|c|c|c|c|c|c|c|}
\hline \multirow[t]{2}{*}{ Date } & \multirow[t]{2}{*}{ Period } & \multicolumn{2}{|c|}{ KW } & \multicolumn{2}{|c|}{$\mathrm{W} / \mathrm{FT}^{2}$} & \multicolumn{2}{|c|}{ WBP\% } \\
\hline & & MAX & Ave & MAX & Ave & MAX & Ave \\
\hline \multirow[t]{2}{*}{ CPP-1 } & Moderate Price (12 pm-3 pm) & 51.6 & 22.8 & 1.33 & 0.59 & $24 \%$ & $11 \%$ \\
\hline & High Price ( 3 pm- 6 pm) & 38.9 & 21.0 & 1.00 & 0.54 & $18 \%$ & $10 \%$ \\
\hline \multirow[t]{2}{*}{ CPP-2 } & Moderate Price ( 12 pm-3 pm) & 45.6 & 20.0 & 1.18 & 0.52 & $23 \%$ & $10 \%$ \\
\hline & High Price ( 3 pm- 6 pm) & 35.5 & 18.8 & 0.91 & 0.48 & $18 \%$ & $9 \%$ \\
\hline \multirow[t]{2}{*}{ CPP-3 } & Moderate Price ( 12 pm-3 pm) & 62.5 & 25.2 & 1.61 & 0.65 & $27 \%$ & $11 \%$ \\
\hline & High Price ( 3 pm- 6 pm) & 42.9 & 26.6 & 1.10 & 0.69 & $19 \%$ & $12 \%$ \\
\hline \multirow[t]{2}{*}{ CPP-4 } & Moderate Price ( 12 pm-3 pm) & 63.9 & 26.1 & 1.65 & 0.67 & $27 \%$ & $11 \%$ \\
\hline & High Price ( 3 pm- $6 \mathrm{pm})$ & 46.8 & 26.7 & 1.21 & 0.69 & $20 \%$ & $11 \%$ \\
\hline \multirow[t]{2}{*}{ CPP-5 } & Moderate Price ( 12 pm-3 pm) & 81.8 & 32.9 & 2.11 & 0.85 & $33 \%$ & $13 \%$ \\
\hline & High Price ( 3 pm- 6 pm) & 52.6 & 27.6 & 1.36 & 0.71 & $21 \%$ & $11 \%$ \\
\hline \multirow[t]{2}{*}{ CPP- 6} & Moderate Price ( 12 pm-3 pm) & 81.2 & 30.8 & 2.09 & 0.79 & $34 \%$ & $13 \%$ \\
\hline & High Price ( 3 pm- $6 \mathrm{pm})$ & 45.3 & 25.1 & 1.17 & 0.65 & $19 \%$ & $11 \%$ \\
\hline \multirow[t]{2}{*}{ CPP-7 } & Moderate Price ( 12 pm-3 pm) & 76.0 & 28.9 & 1.96 & 0.74 & $31 \%$ & $12 \%$ \\
\hline & High Price ( 3 pm- $6 \mathrm{pm})$ & 47.5 & 26.3 & 1.22 & 0.68 & $19 \%$ & $11 \%$ \\
\hline \multirow[t]{2}{*}{ CPP-8 } & Moderate Price ( 12 pm-3 pm) & 75.8 & 28.0 & 1.95 & 0.72 & $32 \%$ & $12 \%$ \\
\hline & High Price ( 3 pm- 6 pm) & 45.2 & 25.4 & 1.16 & 0.65 & $19 \%$ & $11 \%$ \\
\hline \multirow[t]{2}{*}{ CPP-9 } & Moderate Price ( 12 pm-3 pm) & 63.0 & 23.5 & 1.62 & 0.61 & $29 \%$ & $11 \%$ \\
\hline & High Price ( 3 pm- $6 \mathrm{pm})$ & 45.2 & 22.7 & 1.16 & 0.59 & $21 \%$ & $10 \%$ \\
\hline \multirow[t]{2}{*}{ CPP-10 } & Moderate Price ( 12 pm-3 pm) & 65.2 & 24.7 & 1.68 & 0.64 & $31 \%$ & $12 \%$ \\
\hline & High Price ( 3 pm- 6 pm) & 39.1 & 20.6 & 1.01 & 0.53 & $19 \%$ & $10 \%$ \\
\hline \multirow[t]{2}{*}{ CPP-11 } & Moderate Price ( 12 pm-3 pm) & 62.0 & 23.7 & 1.60 & 0.61 & $30 \%$ & $11 \%$ \\
\hline & High Price ( 3 pm- 6 pm) & 38.2 & 20.8 & 0.98 & 0.54 & $18 \%$ & $10 \%$ \\
\hline \multirow[t]{2}{*}{ CPP- 12} & Moderate Price ( 12 pm-3 pm) & 58.7 & 23.2 & 1.51 & 0.60 & $29 \%$ & $11 \%$ \\
\hline & High Price ( 3 pm- 6 pm) & 35.0 & 17.9 & 0.90 & 0.46 & $17 \%$ & $9 \%$ \\
\hline Average & Peak Period ( 12 pm-3 pm) & 54.1 & 24.6 & 1.40 & 0.63 & $24 \%$ & $11 \%$ \\
\hline
\end{tabular}




\section{Table E 4: Simulation Results of Recalibrated Model on CPP Days - One Vanderbilt}

\begin{tabular}{|c|c|c|c|c|c|c|c|}
\hline \multirow[t]{2}{*}{ DATE } & \multirow[t]{2}{*}{ Period } & \multicolumn{2}{|c|}{$\mathbf{k W}$} & \multicolumn{2}{|c|}{$\mathbf{W} / \mathrm{FT}^{2}$} & \multicolumn{2}{|c|}{ WBP\% } \\
\hline & & MAX & Ave & MaX & Ave & Max & Ave \\
\hline \multirow[t]{2}{*}{ CPP-1 } & Moderate Price (12 pm-3 pm) & 92.3 & 43.1 & 1.25 & 0.58 & $21 \%$ & $10 \%$ \\
\hline & High Price ( 3 pm- 6 pm) & 72.2 & 40.9 & 0.98 & 0.56 & $17 \%$ & $9 \%$ \\
\hline \multirow[t]{2}{*}{ CPP-2 } & Moderate Price (12 pm-3 pm) & 82.3 & 38.2 & 1.12 & 0.52 & $20 \%$ & $9 \%$ \\
\hline & High Price ( 3 pm- 6 pm) & 66.5 & 37.5 & 0.90 & 0.51 & $16 \%$ & $9 \%$ \\
\hline \multirow[t]{2}{*}{ CPP-3 } & Moderate Price (12 pm-3 pm) & 113.3 & 48.0 & 1.54 & 0.65 & $25 \%$ & $10 \%$ \\
\hline & High Price ( 3 pm- 6 pm) & 80.5 & 51.1 & 1.09 & 0.69 & $17 \%$ & $11 \%$ \\
\hline \multirow[t]{2}{*}{ CPP- 4} & Moderate Price ( $12 \mathrm{pm}-3 \mathrm{pm})$ & 111.3 & 48.9 & 1.51 & 0.66 & $24 \%$ & $11 \%$ \\
\hline & High Price ( 3 pm-6 pm) & 86.8 & 50.8 & 1.18 & 0.69 & $19 \%$ & $11 \%$ \\
\hline \multirow[t]{2}{*}{ CPP-5 } & Moderate Price (12 pm-3 pm) & 143.5 & 61.3 & 1.95 & 0.83 & $29 \%$ & $12 \%$ \\
\hline & High Price ( 3 pm- 6 pm) & 97.4 & 53.4 & 1.32 & 0.72 & $20 \%$ & $11 \%$ \\
\hline \multirow[t]{2}{*}{ CPP- 6} & Moderate Price (12 pm-3 pm) & 142.6 & 58.3 & 1.93 & 0.79 & $31 \%$ & $12 \%$ \\
\hline & High Price ( 3 pm- 6 pm) & 84.9 & 48.9 & 1.15 & 0.66 & $18 \%$ & $10 \%$ \\
\hline \multirow[t]{2}{*}{ CPP- 7} & Moderate Price (12 pm-3 pm) & 148.3 & 59.2 & 2.01 & 0.80 & $28 \%$ & $11 \%$ \\
\hline & High Price ( 3 pm-6 pm) & 95.6 & 54.6 & 1.30 & 0.74 & $18 \%$ & $10 \%$ \\
\hline \multirow[t]{2}{*}{ CPP-8 } & Moderate Price (12 pm-3 pm) & 142.7 & 56.3 & 1.93 & 0.76 & $29 \%$ & $11 \%$ \\
\hline & High Price ( 3 pm- 6 pm) & 91.1 & 52.6 & 1.24 & 0.71 & $18 \%$ & $11 \%$ \\
\hline \multirow[t]{2}{*}{ CPP-9 } & Moderate Price ( $12 \mathrm{pm}-3 \mathrm{pm})$ & 111.3 & 44.7 & 1.51 & 0.61 & $25 \%$ & $10 \%$ \\
\hline & High Price ( 3 pm- 6 pm) & 91.1 & 44.7 & 1.24 & 0.61 & $21 \%$ & $10 \%$ \\
\hline \multirow[t]{2}{*}{ CPP-10 } & Moderate Price (12 pm-3 pm) & 120.1 & 48.2 & 1.63 & 0.65 & $28 \%$ & $11 \%$ \\
\hline & High Price ( 3 pm- 6 pm) & 77.1 & 42.7 & 1.05 & 0.58 & $18 \%$ & $10 \%$ \\
\hline \multirow[t]{2}{*}{ CPP-11 } & Moderate Price ( $12 \mathrm{pm}-3 \mathrm{pm})$ & 110.3 & 45.9 & 1.50 & 0.62 & $26 \%$ & $11 \%$ \\
\hline & High Price ( 3 pm- 6 pm) & 74.4 & 42.1 & 1.01 & 0.57 & $17 \%$ & $10 \%$ \\
\hline \multirow[t]{2}{*}{ CPP-12 } & Moderate Price ( $12 \mathrm{pm}-3 \mathrm{pm})$ & 104.3 & 44.5 & 1.42 & 0.60 & $25 \%$ & $11 \%$ \\
\hline & High Price ( 3 pm-6 pm) & 67.3 & 36.8 & 0.91 & 0.50 & $16 \%$ & $9 \%$ \\
\hline Average & Peak Period (12 pm-3 pm) & 100.3 & 48.0 & 1.36 & 0.65 & $22 \%$ & $10 \%$ \\
\hline
\end{tabular}




\section{Table E 5: Simulation Results of Recalibrated Model on CPP Days - One Parkside}

\begin{tabular}{|c|c|c|c|c|c|c|c|}
\hline \multirow{2}{*}{ DATE } & \multirow{2}{*}{ Period } & \multicolumn{2}{|c|}{$\mathbf{k W}$} & \multicolumn{2}{|c|}{$\mathbf{W} / \mathrm{FT}^{2}$} & \multicolumn{2}{|c|}{ WBP\% } \\
\hline & & MAX & Ave & MAX & AVE & MAX & Ave \\
\hline \multirow[t]{2}{*}{ CPP- 1} & Moderate Price ( $12 \mathrm{pm}-3 \mathrm{pm}$ ) & 92.8 & 45.0 & 1.33 & 0.64 & $26 \%$ & $13 \%$ \\
\hline & High Price ( 3 pm- 6 pm) & 70.3 & 38.2 & 1.00 & 0.54 & $20 \%$ & $11 \%$ \\
\hline \multirow[t]{2}{*}{ CPP-2 } & Moderate Price ( $12 \mathrm{pm}-3 \mathrm{pm}$ ) & 82.2 & 39.8 & 1.17 & 0.57 & $25 \%$ & $12 \%$ \\
\hline & High Price ( 3 pm- 6 pm) & 64.7 & 35.5 & 0.92 & 0.51 & $19 \%$ & $11 \%$ \\
\hline \multirow[t]{2}{*}{ CPP-3 } & Moderate Price ( $12 \mathrm{pm}-3 \mathrm{pm}$ ) & 115.9 & 50.3 & 1.65 & 0.72 & $31 \%$ & $13 \%$ \\
\hline & High Price ( 3 pm- 6 pm) & 77.6 & 46.5 & 1.11 & 0.66 & $21 \%$ & $12 \%$ \\
\hline \multirow[t]{2}{*}{ CPP-4 } & Moderate Price ( $12 \mathrm{pm}-3 \mathrm{pm})$ & 115.9 & 51.7 & 1.65 & 0.74 & $30 \%$ & $13 \%$ \\
\hline & High Price ( 3 pm- 6 pm) & 85.5 & 48.4 & 1.22 & 0.69 & $22 \%$ & $13 \%$ \\
\hline \multirow[t]{2}{*}{ CPP-5 } & Moderate Price (12 pm-3 pm) & 147.6 & 65.8 & 2.11 & 0.94 & $34 \%$ & $15 \%$ \\
\hline & High Price ( 3 pm- 6 pm) & 98.6 & 52.0 & 1.41 & 0.74 & $23 \%$ & $12 \%$ \\
\hline \multirow[t]{2}{*}{ CPP-6 } & Moderate Price ( 12 pm-3 pm) & 147.0 & 62.3 & 2.10 & 0.89 & $35 \%$ & $15 \%$ \\
\hline & High Price ( 3 pm- 6 pm) & 84.2 & 45.6 & 1.20 & 0.65 & $20 \%$ & $11 \%$ \\
\hline \multirow[t]{2}{*}{ CPP-7 } & Moderate Price (12 pm-3 pm) & 140.7 & 59.6 & 2.01 & 0.85 & $32 \%$ & $13 \%$ \\
\hline & High Price ( 3 pm- 6 pm) & 91.3 & 49.4 & 1.30 & 0.70 & $21 \%$ & $11 \%$ \\
\hline \multirow[t]{2}{*}{ CPP-8 } & Moderate Price ( $12 \mathrm{pm}-3 \mathrm{pm})$ & 136.9 & 57.4 & 1.95 & 0.82 & $32 \%$ & $13 \%$ \\
\hline & High Price ( 3 pm- 6 pm) & 88.7 & 47.8 & 1.27 & 0.68 & $21 \%$ & $11 \%$ \\
\hline \multirow[t]{2}{*}{ CPP-9 } & Moderate Price ( $12 \mathrm{pm}-3 \mathrm{pm}$ ) & 114.5 & 48.0 & 1.63 & 0.69 & $31 \%$ & $13 \%$ \\
\hline & High Price ( 3 pm-6 pm) & 88.7 & 42.1 & 1.27 & 0.60 & $24 \%$ & $12 \%$ \\
\hline \multirow[t]{2}{*}{ CPP-10 } & Moderate Price ( $12 \mathrm{pm}-3 \mathrm{pm}$ ) & 123.6 & 53.2 & 1.76 & 0.76 & $33 \%$ & $14 \%$ \\
\hline & High Price ( 3 pm- 6 pm) & 81.5 & 43.2 & 1.16 & 0.62 & $22 \%$ & $11 \%$ \\
\hline \multirow[t]{2}{*}{ CPP-11 } & Moderate Price ( $12 \mathrm{pm}-3 \mathrm{pm}$ ) & 114.9 & 51.6 & 1.64 & 0.74 & $30 \%$ & $13 \%$ \\
\hline & High Price ( 3 pm- 6 pm) & 78.6 & 41.6 & 1.12 & 0.59 & $20 \%$ & $11 \%$ \\
\hline \multirow[t]{2}{*}{ CPP-12 } & Moderate Price (12 pm-3 pm) & 109.9 & 50.0 & 1.57 & 0.71 & $29 \%$ & $13 \%$ \\
\hline & High Price ( 3 pm- 6 pm) & 72.6 & 38.0 & 1.04 & 0.54 & $19 \%$ & $10 \%$ \\
\hline Average & Peak Period ( 12 pm-3 pm) & 101.0 & 48.4 & 1.44 & 0.69 & $26 \%$ & $12 \%$ \\
\hline
\end{tabular}




\section{Table E 6: Simulation Results of Recalibrated Model on CPP Days - Lakeside Tower}

\begin{tabular}{|c|c|c|c|c|c|c|c|}
\hline \multirow{2}{*}{ DATE } & \multirow{2}{*}{ Period } & \multicolumn{2}{|c|}{ KW } & \multicolumn{2}{|c|}{$\mathrm{W} / \mathrm{FT}^{2}$} & \multicolumn{2}{|c|}{ WBP\% } \\
\hline & & MAX & Ave & Max & Ave & MAX & Ave \\
\hline \multirow[t]{2}{*}{ CPP-1 } & Moderate Price (12 pm-3 pm) & 80.5 & 35.5 & 0.71 & 0.31 & $15 \%$ & $7 \%$ \\
\hline & High Price ( 3 pm-6 pm) & 45.6 & 25.3 & 0.40 & 0.22 & $8 \%$ & $5 \%$ \\
\hline \multirow[t]{2}{*}{ CPP-2 } & Moderate Price ( $12 \mathrm{pm}-3 \mathrm{pm})$ & 79.7 & 33.6 & 0.71 & 0.30 & $16 \%$ & $7 \%$ \\
\hline & High Price ( 3 pm- 6 pm) & 42.2 & 22.8 & 0.37 & 0.20 & $8 \%$ & $4 \%$ \\
\hline \multirow[t]{2}{*}{ CPP-3 } & Moderate Price (12 pm-3 pm) & 97.1 & 47.7 & 0.86 & 0.42 & $17 \%$ & $8 \%$ \\
\hline & High Price ( 3 pm- 6 pm) & 51.9 & 30.2 & 0.46 & 0.27 & $9 \%$ & $5 \%$ \\
\hline \multirow[t]{2}{*}{ CPP- 4} & Moderate Price (12 pm-3 pm) & 93.3 & 43.6 & 0.83 & 0.39 & $16 \%$ & $8 \%$ \\
\hline & High Price ( 3 pm-6 pm) & 50.3 & 28.6 & 0.45 & 0.25 & $9 \%$ & $5 \%$ \\
\hline \multirow[t]{2}{*}{ CPP-5 } & Moderate Price (12 pm-3 pm) & 100.5 & 44.6 & 0.89 & 0.40 & $17 \%$ & $8 \%$ \\
\hline & High Price ( 3 pm- $6 \mathrm{pm})$ & 52.2 & 29.3 & 0.46 & 0.26 & $9 \%$ & $5 \%$ \\
\hline \multirow[t]{2}{*}{ CPP- 6} & Moderate Price ( $12 \mathrm{pm}-3 \mathrm{pm})$ & 99.0 & 43.7 & 0.88 & 0.39 & $17 \%$ & $7 \%$ \\
\hline & High Price ( 3 pm- 6 pm) & 50.4 & 28.7 & 0.45 & 0.25 & $9 \%$ & $5 \%$ \\
\hline \multirow[t]{2}{*}{ CPP- 7} & Moderate Price (12 pm-3 pm) & 119.7 & 65.8 & 1.06 & 0.58 & $19 \%$ & $10 \%$ \\
\hline & High Price ( 3 pm-6 pm) & 77.4 & 39.9 & 0.69 & 0.35 & $12 \%$ & $6 \%$ \\
\hline \multirow[t]{2}{*}{ CPP-8 } & Moderate Price (12 pm-3 pm) & 129.0 & 54.9 & 1.14 & 0.49 & $21 \%$ & $9 \%$ \\
\hline & High Price ( 3 pm- 6 pm) & 67.0 & 37.6 & 0.59 & 0.33 & $11 \%$ & $6 \%$ \\
\hline \multirow[t]{2}{*}{ CPP-9 } & Moderate Price (12 pm-3 pm) & 91.3 & 39.5 & 0.81 & 0.35 & $17 \%$ & $7 \%$ \\
\hline & High Price ( 3 pm- 6 pm) & 67.0 & 27.0 & 0.59 & 0.24 & $12 \%$ & $5 \%$ \\
\hline \multirow[t]{2}{*}{ CPP-10 } & Moderate Price (12 pm-3 pm) & 113.2 & 47.4 & 1.00 & 0.42 & $20 \%$ & $8 \%$ \\
\hline & High Price ( 3 pm- 6 pm) & 53.4 & 26.3 & 0.47 & 0.23 & $9 \%$ & $5 \%$ \\
\hline \multirow[t]{2}{*}{ CPP-11 } & Moderate Price ( $12 \mathrm{pm}-3 \mathrm{pm}$ ) & 99.9 & 46.0 & 0.89 & 0.41 & $17 \%$ & $8 \%$ \\
\hline & High Price ( 3 pm- 6 pm) & 47.4 & 25.7 & 0.42 & 0.23 & $8 \%$ & $4 \%$ \\
\hline \multirow[t]{2}{*}{ CPP-12 } & Moderate Price ( $12 \mathrm{pm}-3 \mathrm{pm})$ & 99.5 & 42.7 & 0.88 & 0.38 & $17 \%$ & $7 \%$ \\
\hline & High Price ( $3 \mathrm{pm}-6 \mathrm{pm})$ & 51.3 & 23.1 & 0.46 & 0.20 & $9 \%$ & $4 \%$ \\
\hline Average & Peak Period (12 pm-3 pm) & 77.5 & 37.1 & 0.69 & 0.33 & $13 \%$ & $6 \%$ \\
\hline
\end{tabular}




\section{Table E 7: Simulation Results of Recalibrated Model on CPP Days - Two Parkside}

\begin{tabular}{|c|c|c|c|c|c|c|c|}
\hline \multirow[t]{2}{*}{ Date } & \multirow[t]{2}{*}{ Period } & \multicolumn{2}{|c|}{ KW } & \multicolumn{2}{|c|}{$\mathbf{W} / \mathrm{FT}^{2}$} & \multicolumn{2}{|c|}{ WBP\% } \\
\hline & & MAX & AVE & MAX & Ave & MAX & $\overline{\text { Ave }}$ \\
\hline \multirow[t]{2}{*}{ CPP-1 } & Moderate Price (12 pm-3 pm) & 109.4 & 52.3 & 1.35 & 0.65 & $31 \%$ & $15 \%$ \\
\hline & High Price ( 3 pm- 6 pm) & 80.1 & 42.5 & 0.99 & 0.53 & $23 \%$ & $12 \%$ \\
\hline \multirow[t]{2}{*}{ CPP-2 } & Moderate Price ( $12 \mathrm{pm}-3 \mathrm{pm})$ & 99.1 & 46.8 & 1.23 & 0.58 & $30 \%$ & $14 \%$ \\
\hline & High Price ( 3 pm- 6 pm) & 73.4 & 39.6 & 0.91 & 0.49 & $22 \%$ & $12 \%$ \\
\hline \multirow[t]{2}{*}{ CPP-3 } & Moderate Price (12 pm-3 pm) & 131.2 & 57.5 & 1.62 & 0.71 & $36 \%$ & $16 \%$ \\
\hline & High Price ( 3 pm- 6 pm) & 86.8 & 49.9 & 1.07 & 0.62 & $23 \%$ & $14 \%$ \\
\hline \multirow[t]{2}{*}{ CPP-4 } & Moderate Price (12 pm-3 pm) & 134.3 & 59.5 & 1.66 & 0.74 & $35 \%$ & $16 \%$ \\
\hline & High Price ( 3 pm- 6 pm) & 96.7 & 53.7 & 1.20 & 0.66 & $25 \%$ & $14 \%$ \\
\hline \multirow[t]{2}{*}{ CPP-5 } & Moderate Price (12 pm-3 pm) & 175.2 & 75.7 & 2.17 & 0.94 & $41 \%$ & $18 \%$ \\
\hline & High Price ( 3 pm- 6 pm) & 111.4 & 57.2 & 1.38 & 0.71 & $26 \%$ & $13 \%$ \\
\hline \multirow[t]{2}{*}{ CPP- 6} & Moderate Price (12 pm-3 pm) & 173.9 & 71.2 & 2.15 & 0.88 & $42 \%$ & $17 \%$ \\
\hline & High Price ( 3 pm- 6 pm) & 94.0 & 48.9 & 1.16 & 0.61 & $23 \%$ & $12 \%$ \\
\hline \multirow[t]{2}{*}{ CPP-7 } & Moderate Price (12 pm-3 pm) & 139.3 & 62.9 & 1.72 & 0.78 & $32 \%$ & $14 \%$ \\
\hline & High Price ( 3 pm- $6 \mathrm{pm})$ & 103.8 & 53.8 & 1.29 & 0.67 & $24 \%$ & $12 \%$ \\
\hline \multirow[t]{2}{*}{ CPP-8 } & Moderate Price ( $12 \mathrm{pm}-3 \mathrm{pm}$ ) & 149.5 & 64.4 & 1.85 & 0.80 & $35 \%$ & $15 \%$ \\
\hline & High Price ( 3 pm- 6 pm) & 99.7 & 51.4 & 1.23 & 0.64 & $24 \%$ & $12 \%$ \\
\hline \multirow[t]{2}{*}{ CPP-9 } & Moderate Price (12 pm-3 pm) & 134.1 & 56.3 & 1.66 & 0.70 & $38 \%$ & $16 \%$ \\
\hline & High Price ( $3 \mathrm{pm}-6 \mathrm{pm})$ & 99.7 & 46.1 & 1.23 & 0.57 & $28 \%$ & $13 \%$ \\
\hline \multirow[t]{2}{*}{ CPP-10 } & Moderate Price (12 pm-3 pm) & 146.0 & 62.4 & 1.81 & 0.77 & $39 \%$ & $16 \%$ \\
\hline & High Price ( 3 pm- 6 pm) & 93.3 & 48.7 & 1.15 & 0.60 & $25 \%$ & $13 \%$ \\
\hline \multirow[t]{2}{*}{ CPP-11 } & Moderate Price (12 pm-3 pm) & 135.5 & 59.7 & 1.68 & 0.74 & $35 \%$ & $16 \%$ \\
\hline & High Price ( 3 pm- $6 \mathrm{pm})$ & 89.6 & 46.4 & 1.11 & 0.57 & $23 \%$ & $12 \%$ \\
\hline \multirow[t]{2}{*}{ CPP-12 } & Moderate Price (12 pm-3 pm) & 130.4 & 58.7 & 1.61 & 0.73 & $35 \%$ & $16 \%$ \\
\hline & High Price ( $3 \mathrm{pm}-6 \mathrm{pm})$ & 84.0 & 43.6 & 1.04 & 0.54 & $22 \%$ & $12 \%$ \\
\hline Average & Peak Period ( $12 \mathrm{pm}-3 \mathrm{pm})$ & 115.4 & 54.5 & 1.43 & 0.68 & $30 \%$ & $15 \%$ \\
\hline
\end{tabular}




\section{Table E 8: Simulation Results of Recalibrated Model on CPP Days - Three Carnegie} Plaza

\begin{tabular}{|c|c|c|c|c|c|c|c|}
\hline \multirow[t]{2}{*}{ DATE } & \multirow[t]{2}{*}{ PERIOD } & \multicolumn{2}{|c|}{$\mathbf{K W}$} & \multicolumn{2}{|c|}{$\mathbf{W} / \mathbf{F T}^{2}$} & \multicolumn{2}{|c|}{ WBP\% } \\
\hline & & MaX & Ave & MaX & Ave & MaX & Ave \\
\hline \multirow[t]{2}{*}{ CPP-1 } & Moderate Price (12 pm-3 pm) & 79.3 & 48.9 & 0.95 & 0.58 & $28 \%$ & $17 \%$ \\
\hline & High Price ( 3 pm- 6 pm) & 48.2 & 36.5 & 0.58 & 0.44 & $17 \%$ & $13 \%$ \\
\hline \multirow[t]{2}{*}{ CPP-2 } & Moderate Price (12 pm-3 pm) & 69.0 & 42.5 & 0.82 & 0.51 & $27 \%$ & $17 \%$ \\
\hline & High Price ( 3 pm- 6 pm) & 45.9 & 32.9 & 0.55 & 0.39 & $18 \%$ & $13 \%$ \\
\hline \multirow[t]{2}{*}{ CPP-3 } & Moderate Price (12 pm-3 pm) & 95.5 & 53.4 & 1.14 & 0.64 & $32 \%$ & $18 \%$ \\
\hline & High Price ( 3 pm- 6 pm) & 55.7 & 45.0 & 0.66 & 0.54 & $19 \%$ & $15 \%$ \\
\hline \multirow[t]{2}{*}{ CPP-4 } & Moderate Price (12 pm-3 pm) & 99.2 & 56.1 & 1.19 & 0.67 & $32 \%$ & $18 \%$ \\
\hline & High Price ( 3 pm- 6 pm) & 62.8 & 47.3 & 0.75 & 0.57 & $20 \%$ & $15 \%$ \\
\hline \multirow[t]{2}{*}{ CPP-5 } & Moderate Price (12 pm-3 pm) & 138.1 & 71.4 & 1.65 & 0.85 & $39 \%$ & $20 \%$ \\
\hline & High Price ( 3 pm-6 pm) & 68.3 & 48.6 & 0.82 & 0.58 & $19 \%$ & $14 \%$ \\
\hline \multirow[t]{2}{*}{ CPP- 6} & Moderate Price (12 pm-3 pm) & 136.9 & 65.9 & 1.64 & 0.79 & $41 \%$ & $20 \%$ \\
\hline & High Price ( 3 pm- 6 pm) & 57.3 & 42.2 & 0.69 & 0.50 & $17 \%$ & $13 \%$ \\
\hline \multirow[t]{2}{*}{ CPP-7 } & Moderate Price (12 pm-3 pm) & 132.2 & 62.0 & 1.58 & 0.74 & $39 \%$ & $18 \%$ \\
\hline & High Price ( 3 pm- 6 pm) & 62.9 & 45.3 & 0.75 & 0.54 & $18 \%$ & $13 \%$ \\
\hline \multirow[t]{2}{*}{ CPP-8 } & Moderate Price (12 pm-3 pm) & 125.3 & 60.5 & 1.50 & 0.72 & $38 \%$ & $18 \%$ \\
\hline & High Price ( 3 pm- 6 pm) & 61.8 & 44.5 & 0.74 & 0.53 & $19 \%$ & $14 \%$ \\
\hline \multirow[t]{2}{*}{ CPP-9 } & Moderate Price (12 pm-3 pm) & 96.1 & 50.9 & 1.15 & 0.61 & $34 \%$ & $18 \%$ \\
\hline & High Price ( 3 pm- $6 \mathrm{pm}$ ) & 55.3 & 40.9 & 0.66 & 0.49 & $19 \%$ & $14 \%$ \\
\hline \multirow[t]{2}{*}{ CPP- 10} & Moderate Price (12 pm-3 pm) & 101.3 & 55.5 & 1.21 & 0.66 & $35 \%$ & $19 \%$ \\
\hline & High Price ( 3 pm- 6 pm) & 55.7 & 40.3 & 0.66 & 0.48 & $19 \%$ & $14 \%$ \\
\hline \multirow[t]{2}{*}{ CPP-11 } & Moderate Price (12 pm-3 pm) & 95.3 & 54.2 & 1.14 & 0.65 & $31 \%$ & $18 \%$ \\
\hline & High Price ( 3 pm- $6 \mathrm{pm}$ ) & 54.8 & 40.4 & 0.66 & 0.48 & $18 \%$ & $13 \%$ \\
\hline \multirow[t]{2}{*}{ CPP- 12} & Moderate Price (12 pm-3 pm) & 92.3 & 52.2 & 1.10 & 0.62 & $32 \%$ & $18 \%$ \\
\hline & High Price ( 3 pm- 6 pm) & 48.7 & 35.2 & 0.58 & 0.42 & $17 \%$ & $12 \%$ \\
\hline Average & Peak Period (12 pm-3 pm) & 80.7 & 48.9 & 0.97 & 0.58 & $26 \%$ & $16 \%$ \\
\hline
\end{tabular}




\section{Table E 9: Simulation Results of Recalibrated Model on CPP Days - Brier Corporate Center}

\begin{tabular}{|c|c|c|c|c|c|c|c|}
\hline \multirow[t]{2}{*}{ DATE } & \multirow[t]{2}{*}{ Period } & \multicolumn{2}{|c|}{ KW } & \multicolumn{2}{|c|}{$\mathrm{W} / \mathrm{FT}^{2}$} & \multicolumn{2}{|c|}{ WBP\% } \\
\hline & & MAX & AVE & MaX & Ave & MAX & AVE \\
\hline \multirow[t]{2}{*}{ CPP-1 } & Moderate Price (12 pm-3 pm) & 98.3 & 59.9 & 0.94 & 0.57 & $23 \%$ & $14 \%$ \\
\hline & High Price ( 3 pm- 6 pm) & 83.8 & 47.7 & 0.80 & 0.46 & $20 \%$ & $11 \%$ \\
\hline \multirow[t]{2}{*}{ CPP-2 } & Moderate Price ( $12 \mathrm{pm}-3 \mathrm{pm})$ & 85.5 & 51.3 & 0.82 & 0.49 & $22 \%$ & $13 \%$ \\
\hline & High Price ( 3 pm- 6 pm) & 75.4 & 44.8 & 0.72 & 0.43 & $19 \%$ & $11 \%$ \\
\hline \multirow[t]{2}{*}{ CPP-3 } & Moderate Price (12 pm-3 pm) & 109.1 & 63.2 & 1.04 & 0.61 & $24 \%$ & $14 \%$ \\
\hline & High Price ( 3 pm- 6 pm) & 92.3 & 59.1 & 0.88 & 0.57 & $21 \%$ & $13 \%$ \\
\hline \multirow[t]{2}{*}{ CPP-4 } & Moderate Price (12 pm-3 pm) & 109.9 & 65.9 & 1.05 & 0.63 & $23 \%$ & $14 \%$ \\
\hline & High Price ( 3 pm- $6 \mathrm{pm})$ & 102.9 & 63.1 & 0.98 & 0.60 & $22 \%$ & $13 \%$ \\
\hline \multirow[t]{2}{*}{ CPP-5 } & Moderate Price (12 pm-3 pm) & 147.1 & 84.3 & 1.41 & 0.81 & $28 \%$ & $16 \%$ \\
\hline & High Price ( 3 pm- 6 pm) & 115.5 & 64.4 & 1.11 & 0.62 & $22 \%$ & $12 \%$ \\
\hline \multirow[t]{2}{*}{ CPP-6 } & Moderate Price (12 pm-3 pm) & 149.9 & 81.7 & 1.43 & 0.78 & $30 \%$ & $17 \%$ \\
\hline & High Price ( 3 pm- 6 pm) & 99.2 & 55.1 & 0.95 & 0.53 & $20 \%$ & $11 \%$ \\
\hline \multirow[t]{2}{*}{ CPP-7 } & Moderate Price ( $12 \mathrm{pm}-3 \mathrm{pm}$ ) & 106.5 & 51.2 & 1.02 & 0.49 & $19 \%$ & $9 \%$ \\
\hline & High Price ( 3 pm- 6 pm) & 106.5 & 71.0 & 1.02 & 0.68 & $19 \%$ & $13 \%$ \\
\hline \multirow[t]{2}{*}{ CPP-8 } & Moderate Price (12 pm-3 pm) & 110.6 & 63.0 & 1.06 & 0.60 & $20 \%$ & $12 \%$ \\
\hline & High Price ( 3 pm- $6 \mathrm{pm})$ & 117.3 & 68.2 & 1.12 & 0.65 & $21 \%$ & $12 \%$ \\
\hline \multirow[t]{2}{*}{ CPP-9 } & Moderate Price (12 pm-3 pm) & 110.4 & 60.8 & 1.06 & 0.58 & $26 \%$ & $15 \%$ \\
\hline & High Price ( 3 pm- 6 pm) & 117.3 & 51.3 & 1.12 & 0.49 & $28 \%$ & $12 \%$ \\
\hline \multirow[t]{2}{*}{ CPP-10 } & Moderate Price (12 pm-3 pm) & 118.3 & 65.5 & 1.13 & 0.63 & $28 \%$ & $15 \%$ \\
\hline & High Price ( 3 pm- 6 pm) & 89.6 & 50.5 & 0.86 & 0.48 & $21 \%$ & $12 \%$ \\
\hline \multirow[t]{2}{*}{ CPP-11 } & Moderate Price ( $12 \mathrm{pm}-3 \mathrm{pm})$ & 108.5 & 63.1 & 1.04 & 0.60 & $25 \%$ & $14 \%$ \\
\hline & High Price ( 3 pm- $6 \mathrm{pm})$ & 88.8 & 50.3 & 0.85 & 0.48 & $20 \%$ & $11 \%$ \\
\hline \multirow[t]{2}{*}{ CPP-12 } & Moderate Price (12 pm-3 pm) & 109.2 & 63.3 & 1.05 & 0.61 & $26 \%$ & $15 \%$ \\
\hline & High Price ( 3 pm- $6 \mathrm{pm})$ & 81.1 & 45.8 & 0.78 & 0.44 & $19 \%$ & $11 \%$ \\
\hline Average & Peak Period (12 pm-3 pm) & 105.5 & 60.2 & 1.01 & 0.58 & $23 \%$ & $13 \%$ \\
\hline
\end{tabular}




\section{Table E 10: Simulation Results of Recalibrated Model on CPP Days - Vanderbilt Plaza}

\begin{tabular}{|c|c|c|c|c|c|c|c|}
\hline \multirow[t]{2}{*}{ DATE } & \multirow[t]{2}{*}{ Period } & \multicolumn{2}{|c|}{ KW } & \multicolumn{2}{|c|}{$\mathrm{W} / \mathrm{FT}^{2}$} & \multicolumn{2}{|c|}{ WBP\% } \\
\hline & & MAX & AVE & MaX & AVE & MAX & Ave \\
\hline \multirow[t]{2}{*}{ CPP-1 } & Moderate Price ( $12 \mathrm{pm}-3 \mathrm{pm})$ & 72.4 & 32.5 & 0.61 & 0.27 & $17 \%$ & $7 \%$ \\
\hline & High Price ( 3 pm- 6 pm) & 44.7 & 25.8 & 0.38 & 0.22 & $10 \%$ & $6 \%$ \\
\hline \multirow[t]{2}{*}{ CPP-2 } & Moderate Price ( $12 \mathrm{pm}-3 \mathrm{pm})$ & 71.3 & 30.0 & 0.60 & 0.25 & $17 \%$ & $7 \%$ \\
\hline & High Price ( 3 pm-6 pm) & 40.9 & 22.9 & 0.34 & 0.19 & $10 \%$ & $6 \%$ \\
\hline \multirow[t]{2}{*}{ CPP-3 } & Moderate Price (12 pm-3 pm) & 87.7 & 42.6 & 0.74 & 0.36 & $19 \%$ & $9 \%$ \\
\hline & High Price ( 3 pm- 6 pm) & 50.5 & 31.6 & 0.42 & 0.27 & $11 \%$ & $7 \%$ \\
\hline \multirow[t]{2}{*}{ CPP-4 } & Moderate Price ( $12 \mathrm{pm}-3 \mathrm{pm})$ & 85.0 & 40.4 & 0.71 & 0.34 & $18 \%$ & $9 \%$ \\
\hline & High Price ( 3 pm- 6 pm) & 49.3 & 29.6 & 0.41 & 0.25 & $11 \%$ & $6 \%$ \\
\hline \multirow[t]{2}{*}{ CPP-5 } & Moderate Price (12 pm-3 pm) & 94.0 & 42.4 & 0.79 & 0.36 & $19 \%$ & $9 \%$ \\
\hline & High Price ( 3 pm- 6 pm) & 51.7 & 30.6 & 0.43 & 0.26 & $11 \%$ & $6 \%$ \\
\hline \multirow[t]{2}{*}{ CPP- 6} & Moderate Price (12 pm-3 pm) & 93.2 & 41.7 & 0.78 & 0.35 & $19 \%$ & $9 \%$ \\
\hline & High Price ( 3 pm- 6 pm) & 50.1 & 30.0 & 0.42 & 0.25 & $10 \%$ & $6 \%$ \\
\hline \multirow[t]{2}{*}{ CPP-7 } & Moderate Price ( $12 \mathrm{pm}-3 \mathrm{pm})$ & 112.3 & 61.2 & 0.94 & 0.51 & $21 \%$ & $12 \%$ \\
\hline & High Price ( 3 pm- 6 pm) & 77.9 & 42.3 & 0.65 & 0.36 & $15 \%$ & $8 \%$ \\
\hline \multirow[t]{2}{*}{ CPP-8 } & Moderate Price (12 pm-3 pm) & 114.2 & 51.7 & 0.96 & 0.43 & $23 \%$ & $10 \%$ \\
\hline & High Price ( 3 pm- $6 \mathrm{pm})$ & 62.2 & 37.9 & 0.52 & 0.32 & $12 \%$ & $8 \%$ \\
\hline \multirow[t]{2}{*}{ CPP-9 } & Moderate Price ( $12 \mathrm{pm}-3 \mathrm{pm})$ & 83.0 & 36.3 & 0.70 & 0.30 & $19 \%$ & $8 \%$ \\
\hline & High Price ( 3 pm- 6 pm) & 62.2 & 27.7 & 0.52 & 0.23 & $14 \%$ & $6 \%$ \\
\hline \multirow[t]{2}{*}{ CPP-10 } & Moderate Price ( $12 \mathrm{pm}-3 \mathrm{pm})$ & 104.1 & 43.8 & 0.87 & 0.37 & $22 \%$ & $9 \%$ \\
\hline & High Price ( 3 pm- 6 pm) & 52.2 & 27.1 & 0.44 & 0.23 & $11 \%$ & $6 \%$ \\
\hline \multirow[t]{2}{*}{ CPP-11 } & Moderate Price (12 pm-3 pm) & 91.2 & 42.6 & 0.77 & 0.36 & $19 \%$ & $9 \%$ \\
\hline & High Price ( 3 pm- $6 \mathrm{pm})$ & 46.3 & 26.3 & 0.39 & 0.22 & $10 \%$ & $6 \%$ \\
\hline \multirow[t]{2}{*}{ CPP-12 } & Moderate Price (12 pm-3 pm) & 91.4 & 39.7 & 0.77 & 0.33 & $20 \%$ & $8 \%$ \\
\hline & High Price ( 3 pm- $6 \mathrm{pm})$ & 50.5 & 23.6 & 0.42 & 0.20 & $11 \%$ & $5 \%$ \\
\hline Average & Peak Period (12 pm-3 pm) & 72.4 & 35.8 & 0.61 & 0.30 & $15 \%$ & $8 \%$ \\
\hline
\end{tabular}




\section{Table E 11: Simulation Results of Regalibrated Model on CPP Days - Inland Regional Center}

\begin{tabular}{|c|c|c|c|c|c|c|c|}
\hline \multirow[t]{2}{*}{ DATE } & \multirow[t]{2}{*}{ Period } & \multicolumn{2}{|c|}{ KW } & \multicolumn{2}{|c|}{$\mathrm{W} / \mathrm{FT}^{2}$} & \multicolumn{2}{|c|}{ WBP\% } \\
\hline & & MAX & AVE & MaX & Ave & MAX & AVE \\
\hline \multirow[t]{2}{*}{ CPP-1 } & Moderate Price ( $12 \mathrm{pm}-3 \mathrm{pm})$ & 76.5 & 56.5 & 0.94 & 0.70 & $23 \%$ & $17 \%$ \\
\hline & High Price ( 3 pm- 6 pm) & 76.1 & 48.2 & 0.94 & 0.59 & $23 \%$ & $14 \%$ \\
\hline \multirow[t]{2}{*}{ CPP-2 } & Moderate Price ( $12 \mathrm{pm}-3 \mathrm{pm})$ & 65.4 & 49.2 & 0.81 & 0.61 & $21 \%$ & $16 \%$ \\
\hline & High Price ( 3 pm-6 pm) & 68.6 & 45.1 & 0.85 & 0.56 & $22 \%$ & $14 \%$ \\
\hline \multirow[t]{2}{*}{ CPP-3 } & Moderate Price (12 pm-3 pm) & 84.9 & 59.8 & 1.05 & 0.74 & $24 \%$ & $17 \%$ \\
\hline & High Price ( 3 pm- 6 pm) & 84.0 & 58.8 & 1.04 & 0.72 & $24 \%$ & $17 \%$ \\
\hline \multirow[t]{2}{*}{ CPP-4 } & Moderate Price ( $12 \mathrm{pm}-3 \mathrm{pm})$ & 88.5 & 62.1 & 1.09 & 0.77 & $24 \%$ & $17 \%$ \\
\hline & High Price ( 3 pm- 6 pm) & 94.5 & 63.5 & 1.17 & 0.78 & $25 \%$ & $17 \%$ \\
\hline \multirow[t]{2}{*}{ CPP-5 } & Moderate Price (12 pm-3 pm) & 120.6 & 79.5 & 1.49 & 0.98 & $30 \%$ & $20 \%$ \\
\hline & High Price ( 3 pm- 6 pm) & 105.8 & 64.5 & 1.30 & 0.80 & $27 \%$ & $16 \%$ \\
\hline \multirow[t]{2}{*}{ CPP- 6} & Moderate Price (12 pm-3 pm) & 120.8 & 75.8 & 1.49 & 0.94 & $32 \%$ & $20 \%$ \\
\hline & High Price ( 3 pm- 6 pm) & 90.2 & 54.7 & 1.11 & 0.67 & $24 \%$ & $14 \%$ \\
\hline \multirow[t]{2}{*}{ CPP-7 } & Moderate Price ( $12 \mathrm{pm}-3 \mathrm{pm})$ & 107.4 & 69.1 & 1.32 & 0.85 & $26 \%$ & $17 \%$ \\
\hline & High Price ( 3 pm- 6 pm) & 102.2 & 62.1 & 1.26 & 0.77 & $25 \%$ & $15 \%$ \\
\hline \multirow[t]{2}{*}{ CPP-8 } & Moderate Price (12 pm-3 pm) & 109.8 & 70.1 & 1.35 & 0.86 & $28 \%$ & $18 \%$ \\
\hline & High Price ( 3 pm- $6 \mathrm{pm})$ & 96.1 & 57.8 & 1.18 & 0.71 & $24 \%$ & $15 \%$ \\
\hline \multirow[t]{2}{*}{ CPP-9 } & Moderate Price ( $12 \mathrm{pm}-3 \mathrm{pm})$ & 84.8 & 57.3 & 1.05 & 0.71 & $25 \%$ & $17 \%$ \\
\hline & High Price ( 3 pm- 6 pm) & 96.1 & 50.7 & 1.18 & 0.63 & $29 \%$ & $15 \%$ \\
\hline \multirow[t]{2}{*}{ CPP-10 } & Moderate Price (12 pm-3 pm) & 88.4 & 60.7 & 1.09 & 0.75 & $26 \%$ & $18 \%$ \\
\hline & High Price ( 3 pm- 6 pm) & 79.9 & 50.3 & 0.99 & 0.62 & $24 \%$ & $15 \%$ \\
\hline \multirow[t]{2}{*}{ CPP-11 } & Moderate Price (12 pm-3 pm) & 83.1 & 58.6 & 1.02 & 0.72 & $24 \%$ & $17 \%$ \\
\hline & High Price ( 3 pm- 6 pm) & 80.4 & 50.3 & 0.99 & 0.62 & $23 \%$ & $15 \%$ \\
\hline \multirow[t]{2}{*}{ CPP-12 } & Moderate Price (12 pm-3 pm) & 82.6 & 59.1 & 1.02 & 0.73 & $25 \%$ & $18 \%$ \\
\hline & High Price ( 3 pm- 6 pm) & 74.6 & 46.9 & 0.92 & 0.58 & $22 \%$ & $14 \%$ \\
\hline Average & Peak Period (12 pm-3 pm) & 90.1 & 58.8 & 1.11 & 0.73 & $25 \%$ & $16 \%$ \\
\hline
\end{tabular}


